UNIVERSIDADE DE SÃO PAULO
FACULDADE DE CIÊNCIAS FARMACÊUTICAS DE RIBEIRÃO PRETO

Consequências da imunossenescência frente à infecção experimental por Trypanosoma cruzi

Rafaela Pravato Colato

Ribeirão Preto 


\author{
UNIVERSIDADE DE SÃO PAULO \\ FACULDADE DE CIÊNCIAS FARMACÊUTICAS DE RIBEIRÃO PRETO
}

\title{
Consequências da imunossenescência frente à infecção experimental por Trypanosoma cruzi
}

\begin{abstract}
Tese de Doutorado apresentada ao Programa de PósGraduação em Biociências Aplicadas à Farmácia da Faculdade de Ciências Farmacêuticas de Ribeirão Preto, para obtenção do título de Doutor em Ciências.
\end{abstract}

Área de concentração: Biociências Aplicadas à Farmácia

Orientada: Rafaela Pravato Colato

Orientador: Prof. Dr. José Clóvis do Prado Júnior Coorientadora: Profa. Dra. Gabriela Silva Bisson

Versão corrigida da Tese de Doutorado apresentada ao Programa de Pós Graduação em Biociências Aplicadas à Farmácia em 17/07/2018. A versão original encontra-se disponível na Faculdade de Ciências Farmacêuticas de Ribeirão Preto/USP.

\author{
Ribeirão Preto
}


AUTORIZO A REPRODUÇÃO E DIVULGAÇÃO TOTAL OU PARCIAL DESTE TRABALHO, POR QUALQUER MEIO CONVENCIONAL OU ELETRÔNICO, PARA FINS DE ESTUDO E PESQUISA, DESDE QUE CITADA A FONTE.

Colato, R.P.

Consequências da imunossenescência frente à infecção experimental por Trypanosoma cruzi.

$166 \mathrm{f.:}$ fig.

Tese de Doutorado apresentada à Faculdade de Ciências Farmacêuticas de Ribeirão Preto - USP - Área de Concentração: Biociências Aplicadas à Farmácia. Orientador: Do Prado Júnior, José Clóvis - Ribeirão Preto, 2018.

1. Trypanosoma cruzi 2. Imunosenescência 3. Linfócitos 


\section{FOLHA DE APROVAÇÃO}

Aluna: Rafaela Pravato Colato

Título: Consequências da imunossenescência frente à infecção experimental por Trypanosoma cruzi.

Tese de Doutorado apresentada ao Programa de Pós Graduação em Biociências Aplicadas à Farmácia, para obtenção do título de Doutor em Ciências.

Área de concentração: Biociências Aplicadas à Farmácia Orientada: Rafaela Pravato Colato

Orientador: Prof. Dr. José Clóvis do Prado Júnior Coorientadora: Profa. Dra. Gabriela Silva Bisson

Aprovado em:

Banca Examinadora

Prof. Dr.

Instituição: Assinatura:

Prof. Dr. Instituição: Assinatura:

Prof. Dr. Instituição: Assinatura:

Prof. Dr. Instituição: Assinatura:

Prof. Dr. Instituição: Assinatura: 
DEDICATÓRIA 
Dedico este trabalho à minha família que com muito amor, confiança e sabedoria de vida me conduziram até aqui. Amo muito todos vocês! 
AGRADECIMENTOS 
Agradeço infinitamente a Deus, Nossa Senhora das Graças, Nossa Senhora da Glória, Santa Rita de Cássia e ao meu guia espiritual "Shirley", que sempre me deram forças, coragem, capacidade, perseverança, amor e muita fé para conseguir alcançar meus objetivos, desenvolver e concluir este trabalho, bem como tudo durante a minha caminhada.

Aos meus pais, Idair e Maria Inês que sempre me apoiaram de maneira incondicional. Obrigada por todo amor, paciência, dedicação, apoio e compreensão ao longo de toda minha vida. Eu não seria nada sem vocês.

À minha irmã Mariane, que sempre me apoiou e entendeu a minha ausência todos esses anos. Nada disso seria possível sem a sua ajuda e compreensão.

À minha linda sobrinha, Ana Júlia por ter trazido mais cor e alegria aos meus dias. Você é a minha riqueza!

Aos demais da minha família (vô Zeca, vó Arides (in memoriam), vô Doca (in memoriam), vó Dyrce, tia Márcia, tia Nair, Vitória e Vinícius) pelo incentivo, carinho e forças.

Ao professor José Clóvis, pessoa de um coração sem igual. Competente, inteligente que sempre esteve disposto a me ensinar e direcionar-me para o melhor. Obrigada pela confiança e oportunidade de fazer parte do seu grupo de pesquisa. Seus ensinamentos contribuíram muito para o meu amadurecimento, crescimento pessoal e profissional. Serei eternamente grata por tudo.

À professora Gabriela Silva Bisson, pessoa incrível que me acolheu no seu laboratório e me apoiou a todo instante. Nunca esquecerei o que fez por mim. Obrigada por tudo!

Aos professores Sérgio de Albuquerque e Ana Amélia, pelo apoio e convivência no laboratório.

Ao professor Carlos Tirapelli, pela disponibilidade e parceria que enriqueceram este trabalho.

Aos membros da banca examinadora por toda atenção e disposição.

Aos meus grandes amigos e parceiros Gabriel, Vânia e Fabrícia, que me ajudaram muito no decorrer desses anos. Obrigada pelo apoio, amizade, incentivo e discussões enriquecedoras que foram imprescindíveis. Vocês se tornaram mais que especiais.

A todos os amigos do laboratório de parasitologia da FCFRP obrigada pela amizade, companheirismo e apoio. 
Aos amigos do laboratório de farmacologia da EERP Natália e Janaína que também contribuíram no desenvolvimento deste trabalho.

À Miriam Toldo, agradeço pela ajuda na execução da parte prática que foi de extrema importância, pelo carinho e amizade.

Aos técnicos Georgius, Cristiana e Inara, por todo apoio e dedicação no laboratório, que foi de extrema importância para tudo acontecer.

Ao professor José Antunes Rodrigues e as técnicas Milena e Val pela disponibilidade e ajuda na realização da quantificação de corticosterona.

À Regina, Andressa (Bibi), Rafa Poloni e Stefany, amigos pra todas as horas, que sempre me apoiaram. Obrigada pelo carinho, compreensão e amizade todos esses anos. Presente que Ribeirão Preto me deu e que levarei por toda a vida. Eu amo muito vocês!

À Ranna, que também faz parte da minha vida. Obrigada pelo carinho e companheirismo todo esse tempo.

À minha amiga Bruna que chegou de repente e que já faz parte da minha vida. Obrigada por me ajudar em tudo! Você já é uma irmã pra mim.

Aos funcionários do Biotério, Reinaldo e Ronaldo (FCFRP-USP) pelo cuidado e zelo com os animais.

À Fabiana Rosseto de Moraes, pelos ensinamentos sobre citometria de fluxo e pela enorme contribuição neste trabalho.

Aos funcionários da pós graduação, pela paciência e dedicação.

À Universidade de São Paulo que através da FCFRP e a CAPES me forneceram o suporte intelectual e material para a realização deste estudo.

À Fundação de Amparo à Pesquisa do Estado de São Paulo (FAPESP), sob o processo de número 2014/00303-6, pela concessão da bolsa de doutorado e pelo apoio financeiro para a realização deste trabalho.

Só tenho a agradecer a todos por tudo! Muito obrigada de todo coração. 
"Se eu vi mais longe, foi por estar de pé sobre ombros de gigantes."

(Isaac Newton) 


\section{RESUMO}

COLATO, R. P. Consequências da imunossenescência frente à infecção experimental por Trypanosoma cruzi. 2018. Faculdade de Ciências Farmacêuticas de Ribeirão Preto - Universidade de São Paulo, Ribeirão Preto, 2018.

Apesar de todo o avanço científico nas últimas décadas, a doença de Chagas ainda é um importante problema em saúde pública. A expectativa de vida no Brasil tem aumentado a cada ano e esse crescimento permite o surgimento de uma população idosa em risco de contrair essa doença. Diante disso, os objetivos deste trabalho foram avaliar a resposta imune em ratos Wistar senescentes, infectados pela cepa $Y$ de $T$. cruzi. O presente estudo mostrou alterações na imunidade inata, quando avaliamos a população de macrófagos peritoneais, bem como a sinalização (expressão de RT1B) e da molécula coestimulatória (CD80) das células APC nos animais senis. A imunidade celular também foi reduzida, uma vez que os animais senis apresentaram uma diminuição significativa na porcentagem de linfócitos T CD4 ${ }^{+}$e T CD8 ${ }^{+}$, quando comaprados aos jovens. Além disso, foi observado que o envelhecimento reduz a expressão da principal molécula de sinalização, o CD28 ${ }^{+}$, responsável pela ativação de células $T$. Nos nossos estudos, o envelhecimento foi associado a um aumento no percentual de linfócitos $\mathrm{CD} 4^{+} \mathrm{CD} 25^{\text {low }} \mathrm{FOXP} 3^{+}$, que representam as células $T$ regulatórias instáveis. Por outro lado, os animais senis não infectados apresentaram uma redução significante no percentual de linfócitos $\mathrm{CD} 4^{+} \mathrm{CD} 25^{\text {high }} \mathrm{FOXP} 3^{+}$, as células $T$ regulatórias estáveis. A senesescência, bem como, o processo infeccioso ocasionaram um aumento nos níveis de corticosterona e no percentual de esplenócitos em apoptose inicial e tardia em animais senis infectados. $O$ envelhecimento também regulou negativamente a transição DN1-DN2, bem como, as subpopulações de timócitos DN3 e DN4 em animais senis, infectados ou não. Observou-se uma redução no percentual de timócitos viáveis nos animais senis, tanto controles quanto infectados. Com relação aos parâmetros do estresse oxidativo, a senilidade elevou os níveis de TBARS, reduziu a atividade da principal enzima antioxidante SOD e na concentração de 8-isoprostano. O substrato da enzima glutationa peroxidase GSH aumentou nesses animais senis, comparados aos jovens. A análise da produção de citocinas evidenciou um aumento nos níveis de TGF- $\beta$ em animais senis. No $16^{\circ}$ dia após a infecção, um aumento nos níveis de IL-12 foram observados apenas nos animais senis infectados. Entretanto, este mesmo grupo apresentou uma redução na produção de IL-2 no $9^{\circ}$ dia após a infecção. As concentrações de IL-17 foram maiores nos animais senis infectados e controles, quando comparados aos animais jovens. Tanto a infecção por $T$. cruzi quanto o envelhecimento ocasionaram um aumento nos níveis de TNF- $\alpha$ nos animais jovens e senis infectados. Com o presente estudo, conseguimos avançar na compreensão dos mecanismos celulares e moleculares envolvidos nas modificações da imunidade ao longo da vida e seus reflexos frente à doença de Chagas. Inúmeras alterações foram observadas, incluindo resposta imune ineficiente, aumento do estresse oxidativo, bem como diminuição da atividade de enzimas antioxidantes e comprometimento no processo de maturação celular intratímica, os quais afetam etapas essenciais no desenvolvimento dos timócitos e exportação de células $T$ para a periferia. Foi observado um desequilíbrio funcional do eixo neuroendócrino, bem como a diminuição da viabilidade celular. Além disso, as mudanças no perfil da produção de citocinas promoveram implicações diretas na competência imunológica desses animais.

Palavras-chave: Trypanosoma cruzi, Imunossenescência, linfócitos 


\begin{abstract}
COLATO, R. P. Consequences of immunosenescence against the experimental infection by Trypanosoma cruzi. 2018. College of Pharmaceutical Sciences of Ribeirão Preto (FCFRP), University of São Paulo, Ribeirão Preto, 2018.
\end{abstract}

Despite all the scientific advances in the last decades, Chagas disease is still an important public health problem. Every year, the life expectancy in Brazil has increased and this growth tops with the emergence of an elderly population at risk of contracting this disease. Therefore, the objectives of this study were to evaluate the immune response in senescent Wistar rats, infected with $T$. cruzi $Y$ strain. Changes in innate immunity was observed in the population of peritoneal macrophages, as well as signaling (RT1B expression) and the costimulatory molecule (CD80) of APC cells in senile animals. Cellular immunity was also reduced, since senile animals showed a significant decrease in the percentage of $C D 4^{+} T$ and $C D 8^{+} T$ lymphocytes when compared to young counterparts. A reduced expression of the major signaling molecule, $\mathrm{CD}^{2} 8^{+}$, responsible for $\mathrm{T}$ cell activation was also observed as long as animals age. Aging was associated with an increase in the percentage of $\mathrm{CD}^{2} 5^{+} \mathrm{CD} 25$ lowFOXP3 ${ }^{+}$lymphocytes, which represent $\mathrm{T}$ regulator cells. On the other hand, the uninfected senile animals presented a significant reduction in the percentage of $\mathrm{CD}^{+}{ }^{+} \mathrm{CD} 25^{\text {high }} \mathrm{FOXP3} 3^{+}$lymphocytes. Senescence as well as the infectious process triggered an increase in corticosterone levels and in the percentage of splenocytes in early and late apoptosis in senile infected animals. Aging also negatively regulated the DN1-DN2 transition, as well as the subpopulations of thymocytes DN3 and DN4 in senile animals, infected or not. A reduction in the percentage of viable thymocytes was observed in control and infected senile animals. Regarding to oxidative stress, aging increased the levels of TBARS, reduced the activity of the main antioxidant enzyme SOD and the concentration of 8-isoprostane. Oppositely, aged animals displayed increased levels of the enzyme glutathione peroxidase GSH as compared to the young ones. The analysis of cytokine production evidenced an increase in TGF- $\beta$ levels in senile animals. On the 16th day after infection, enhanced concentrations of IL-12 was observed only in senile infected animals. However, this same group showed a reduction in IL-2 production on the 9th day after infection. Senile and control animals displayed higher IL-17 concentrations when compared to young animals. Both $T$. cruzi infection and aging caused an increase in TNF- $\alpha$ levels in young and senile infected animals. The present study allowed us to better understand the cellular and molecular mechanisms involved in the immune response throughout life and its actions on Chagas' disease. For that, several alterations were observed such as an inefficient immune response, increased oxidative stress, decreased antioxidant enzyme activity and impairment in the intratymic cell maturation process, impairing thymocyte development and the export of T cells to the periphery, as well decreased cell viability. A functional imbalance of the neuroendocrine axis was also observed, as well as changes in the profile of cytokine production directly impairing the immune competence in these animals.

Keywords: Trypanosoma cruzi, Immunosenescence, lymphocytes 


\section{LISTA DE FIGURAS}

Figura 1: Análise da porcentagem da população de macrófagos $(A)$ e macrófagos ativados via MHC-II (molécula RT1B ${ }^{+}$) (B) no lavado peritoneal.

Figura 2: Caracterização fenotípica de células dendríticas obtidas a partir do lavado peritoneal (A) e Baço (B).

Figura 3: Análise da expressão das moléculas CD80 (A) e CD86 (B) em células apresentadoras de antígenos (APC).....

Figura 4: Análise da porcentagem das populações de células NK (A) e NKT (B)...57

Figura 5: Análise da porcentagem das subpopulações de linfócitos $T C D 3^{+} C D 4^{+}(A)$ e T CD3 ${ }^{+} \mathrm{CD}^{+}$(B) no baço. . .59

Figura 6: Análise do percentual de linfócitos T CD4 ${ }^{+} C D 28^{-}(A), T$ CD8 ${ }^{+} C D 28^{-}$(B) e T $\mathrm{CD}^{+}{ }^{+} \mathrm{CD} 28^{-}(\mathrm{C})$ em células esplênicas.

Figura 7: Análise da porcentagem da coestimulação das subpopulações de linfócitos $\mathrm{T} \mathrm{CD}^{+}(\mathrm{A})$ e linfócitos $\mathrm{T} \mathrm{CD8}{ }^{+}(\mathrm{B})$...

Figura 8: Análise da porcentagem da população de linfócitos B no baço .65

Figura 9: Análise fenotípica dos linfócitos $T C D 4^{+} C D 25^{\text {high }}(A)$ e T CD4 ${ }^{+} C D 25^{-}$(B) no baço.

Figura 10: Análise da expressão do fator de transcrição FOXP3 em células $\mathrm{CD} 4{ }^{+} \mathrm{CD} 25^{\text {low }}(\mathrm{A})$ e $\mathrm{CD} 4^{+} \mathrm{CD} 25^{\text {high }}$ (B) no baço. .68

Figura 11: Análise da concentração de corticosterona no plasma. .70

Figura 12: Marcação de células esplênicas de ratos Wistar utilizando anexina $\vee \mathrm{e}$ iodeto de propídeo.

Figura 13: Análise da população de esplenócitos viáveis utilizando anexina $\mathrm{V}$ e iodeto de propídeo .74

Figura 14: Peso do timo $(\mathrm{g})(\mathrm{A})$ e número de timócitos $\left(\mathrm{mm}^{3}\right)(\mathrm{B}) \ldots \ldots \ldots \ldots \ldots \ldots \ldots \ldots \ldots . . . .76$

Figura 15: Caracterização de timócitos DN1 (A), DN3 (B) e DN4 (C) .78 


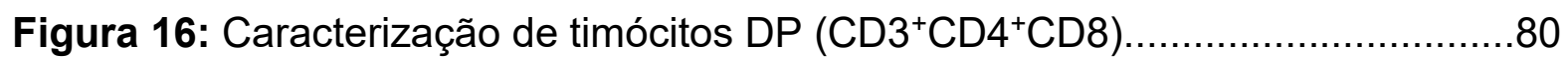

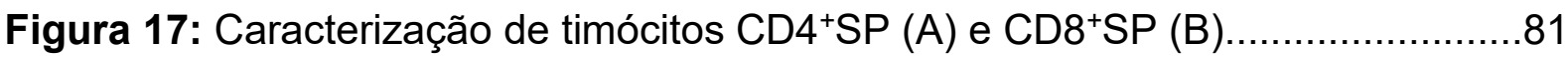

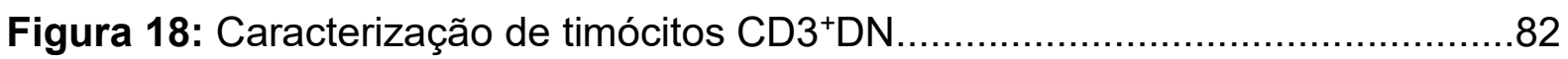

Figura 19: Marcação de timócitos de ratos Wistar utilizando anexina $V$ e iodeto de propídeo

Figura 20: Análise da população de timócitos viáveis utilizando anexina $\mathrm{V}$ e iodeto de propídeo .86

Figura 21: Análise indireta da concentração de óxido nítrico no lavado peritoneal..88

Figura 22: Análise indireta da concentração de óxido nítrico no soro .90

Figura 23: Análise da peroxidação lipídica, através da concentração das substâncias reativas ao ácido tiobarbitúrico (TBARS). 92

Figura 24: Avaliação da atividade da enzima Superóxido dismutase (SOD) no plasma.

Figura 25: Quantificação do 8-isoprostano no plasma. .96

Figura 26: Quantificação da glutationa (GSH) no plasma. 98

Figura 27: Análise da peroxidação lipídica, através da concentração das substâncias reativas ao ácido tiobarbitúrico (TBARS) no tecido tímico. 100

Figura 28: Avaliação da atividade da enzima Superóxido dismutase (SOD) no timo. 102

Figura 29: Geração de $\mathrm{O}^{2-}$ e expressão de NOX2 e SOD2 no timo 104

Figura 30: Concentrações de TGF- $\beta$ ( $\mathrm{pg} / \mathrm{mL})$ determinadas no soro 107

Figura 31: Concentrações de IL-2 (pg/mL) determinadas no soro 108

Figura 32: Concentrações de lL-12 (pg/mL) determinadas no soro. 109

Figura 33: Concentrações de lL-17 (pg/mL) determinadas no soro. 110

Figura 34: Concentrações de TNF- $\alpha(\mathrm{pg} / \mathrm{mL})$ determinadas no soro 


\section{LISTA DE TABELAS}

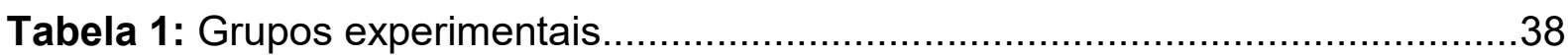

Tabela 2: Marcadores celulares que foram analisados ......................................4

Tabela 3: Anticorpos monoclonais que foram utilizados na análise fenotípica das células esplênicas e timócitos...................................................................41

Tabela 4: Anticorpos primários e secundários utilizados no protocolo de Western

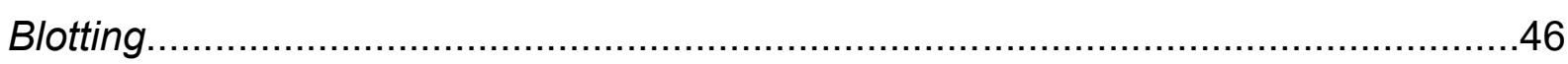




\section{LISTA DE ABREVIATURAS E SIGLAS}

ACTH: Hormônio adrenocorticotrófico

APCs: Células apresentadoras de antígenos

ATP: Adenosina trifosfato

${ }^{\circ} \mathrm{C}$ : Graus Celsius

CAT: Catalase

CD: Cluster of Differentiation

CEUA: Comitê de Ética no Uso de Animais

CFSE: Carboxifluoresceínadiacetatosuccinimidil éster

$\mathrm{CO}_{2}$ : Dióxido de Carbono

$\mathrm{CRH}$ : Hormônio liberador de corticotrofina

DN: Duplo-negativos

DP: Duplo-positivos

D.O.: Densidades ópticas

Duox: Família da NADPH oxidase

E.coli: Escherichia coli

ELISA: Enzyme-Linked Immunosorbent Assay

EROs: Espécies Reativas de Oxigênio

FCFRP-USP: Faculdade de Ciências Farmacêuticas de Ribeirão Preto Universidade de São Paulo

Fcblock: Bloqueador de ligações não específicas

GPx: Glutationa Peroxidase

GSH: Glutationa Reduzida

GSSG: Glutationa Oxidada

$\mathrm{H}^{+}$: Hidrogênio

$\mathrm{H}_{2} \mathrm{O}_{2}$ : Peróxido de Hidrogênio 
HPA: Hipotálamo Hipófise Adrenal

$\mathrm{H}_{3} \mathrm{PO}_{4}$ : Ácido fosfórico

HPR: Estreptavidina-peroxidase

JC: Jovem Controle

JI: Jovem Infectado

Kg: Quilogramas

IFN-ү: Interferon gamma

IgG: Imunoglobulina G

IL: Interleucina

iNOS: Óxido Nítrico Sintase Induzida

i.p.: Intraperitoneal

LPS: Lipopolissacarídeos

mAbs: Anticorpos monoclonais

MDA: Malondialdeído

MHC: Complexo de Histocompatibilidade

$\mathrm{mL}$ : Mililitros

mg: Miligramas

min: Minutos

$\mu g$ : Microgramas

$\mu \mathrm{L}:$ Microlitros

mm: Milímetros

$\mu \mathrm{M}$ : Micromolar

NADPH: Nicotinamida Adenina Dinucleotídeo Fosfato

NK: Células Natural Killer

NKT: Célula Natural Killer T

NO: Óxido Nítrico

NOS: Óxido Nítrico Sintase 
NOXs: Família Nonphagocytic NADPH Oxidases

$\mathrm{O}_{2}:$ Ânion Superóxido

O2: Oxigênio

nm: Nanômetro

nmol: Nanomolar

NO2: Nitriro

NO3: Nitrato

ONOO: Peroxinitrito

8-isoprostano: 8-iso prostaglandina $\mathrm{F}_{2 \alpha}$

PAMPS: Pathogen-Associated Molecular Patterns

PBS: Tampão Fosfato Salino (Phosphate buffered saline)

pH: Potencial hidrogeniônico

PE: Ficoeritrina ( $r$ - phicoeritrin)

PERCP: Complexo protéico clorofila-peridina (Peridin clorofil protein)

pg: Picogramas

PI: lodeto de propídeo

PRRs: Receptores de reconhecimento padrão

rpm: Rotações por minuto

RPMI: Meio de cultura (Roswell park memorial institute)

SBF: Soro Bovino Fetal

SC: Senil controle

SI: Senil Infectado

SOD: Superóxido dismutase

TBA: Ácido tiobarbitúrico

TBARS: Substâncias Reativas ao Ácido Tiobarbitúrico

TCR: Receptor de linfócito T (T cell)

T.cruzi: Trypanosoma cruzi 
TGF- $\beta$ : Fator de transformação do crescimento beta

Th1: Células T helper 1

Th2: Células T helper 2

Th17: Células T helper 17

TLRs: Receptores do tipo toll

TNF- $\alpha$ : Fator de necrose tumoral alfa

Tregs: células T Reguladoras

U.I.: Unidade Internacional

WHO: World Health Organization 
Resumo

Abstract

Lista de figuras

Lista de tabelas

Lista de abreviaturas e siglas

1. INTRODUÇÃO

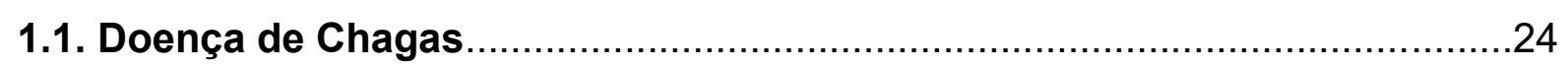

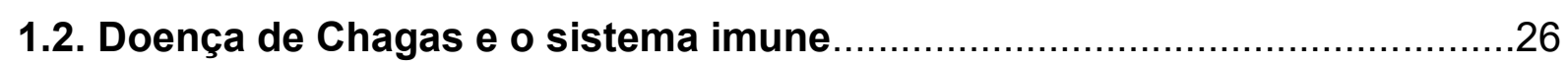

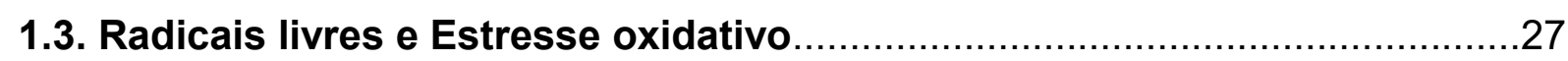

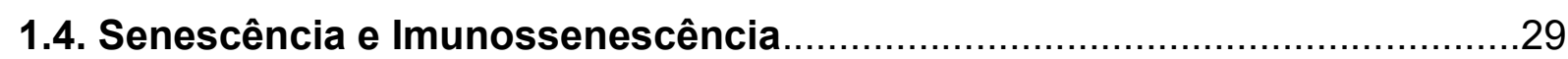

2. JUSTIFICATIVA.

3. OBJETIVOS. .36

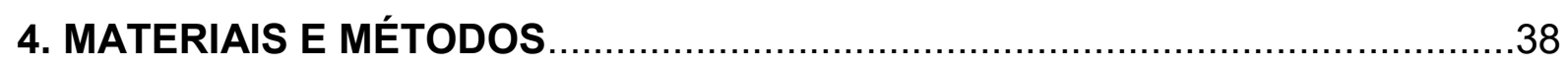

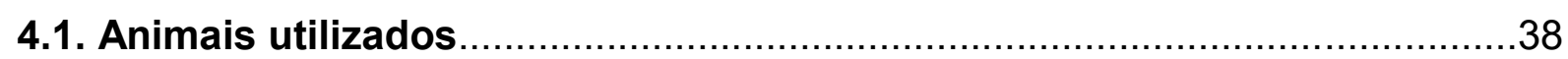

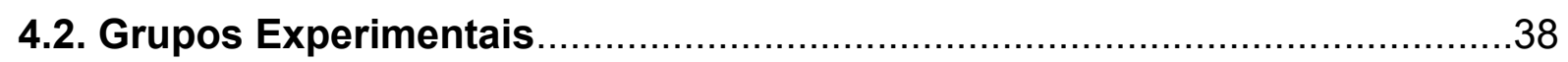

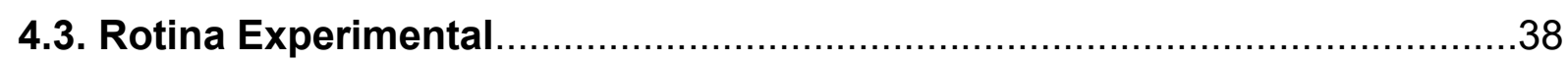

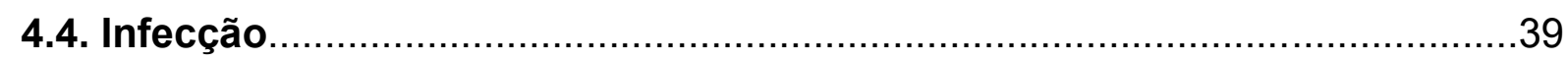

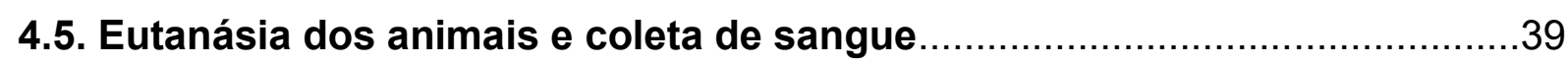

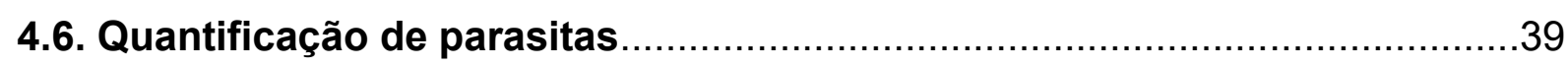

4.7. Contagem global de macrófagos peritoneais ............................................39

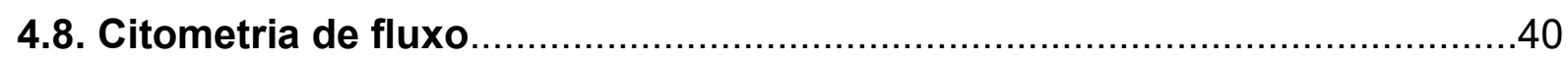

4.8.1. Caracterização fenotípica e funcional de macrófagos e células

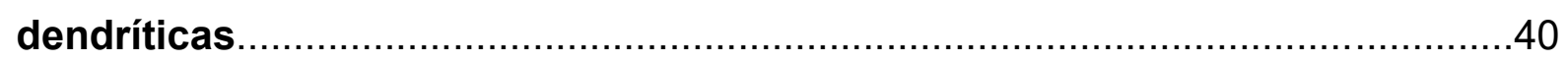

4.8.2. Análise fenotípica das populações celulares nas células esplênicas.....40

4.8.3. Caracterização de células $\mathrm{T}$ reguladoras $\mathrm{T} \mathrm{CD}^{+} \mathrm{CD}^{+} 5^{+}$através da expressão do fator de transcrição FOXP3 ……..........................................

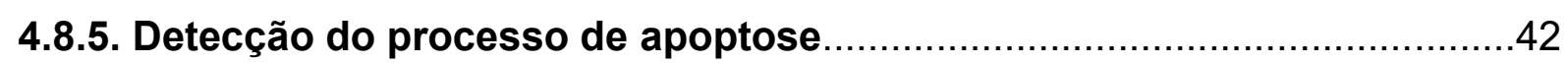

4.8.6. Análise fenotípica das populações celulares nos timócitos ………….......43 
4.9. Avaliação do estresse oxidativo 43

4.9.1. Quantificação indireta de óxido nítrico. 43

4.9.2. Quantificação de óxido nítrico no soro. .43

4.9.3. Análise das concentrações das substâncias reativas ao ácido tiobarbitúrico (TBARS) no plasma, no timo e no tecido cardíaco. .44

4.9.4. Avaliação plasmática da atividade da Superóxido Dismutase (SOD) no plasma e no timo. 44

4.9.5. Determinação das concentrações plasmáticas do 8-isoprostano. .44

4.9.6. Quantificação da Glutationa (GSH) (glutationa reduzida) no plasma.......45 4.9.7. Detecção de $\mathrm{O}_{2}^{-}$pelo método de quimioluminescência da lucigenina no timo

4.9.8. Avaliação da expressão enzimática da NOX2 e SOD2 no timo de ratos Wistar pela técnica de Western Blotting 46

4.10. Quantificação de corticosterona. .46

4.11. Ensaio Imunoenzimático (ELISA) 47

4.11.1. Níveis séricos de TGF- $\beta$, IL-2, IL-12, IL-17 e TNF- $\alpha$.

5. ANÁLISE ESTATÍSTICA.

6. RESULTADOS .51

6.1. Caracterização fenotípica e funcional de macrófagos peritoneais. .51

6.2. Análise fenotípica e funcional de células dendríticas. .53

6.3. Avaliação do percentual de células NK (CD161 $)$ e NKT $\left(C D 3^{+} C D 161^{+}\right)$em células esplênicas. .56

6.4. Análise das subpopulações de linfócitos $T \mathrm{CD}^{+}$e $\mathrm{CD}^{+}$em células esplênicas .58

6.5. Análise da expressão de CD28 nas subpopulações de linfócitos T CD4+ e CD8 ${ }^{+}$.

6.6. Avaliação do percentual de linfócitos $B\left(C^{2} 45 A^{+}\right)$em células esplênicas

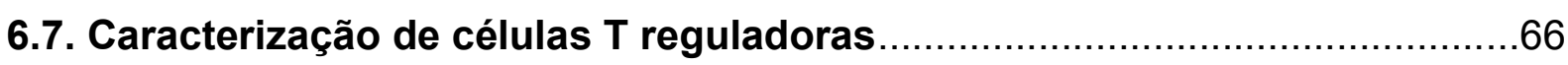

6.8. Quantificação de corticosterona........................................................69

6.9. Análise do processo de apoptose ..................................................... 71

6.10. Análise da população de esplenócitos viáveis ......................................73 
6.11. Caracterização do processo de diferenciação intratímica.

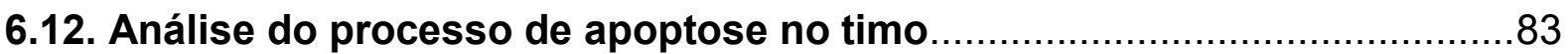

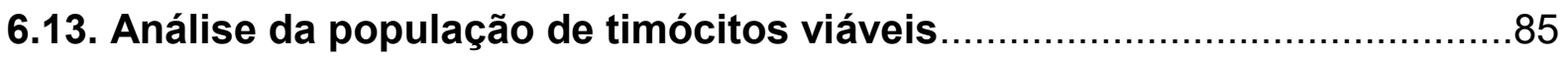

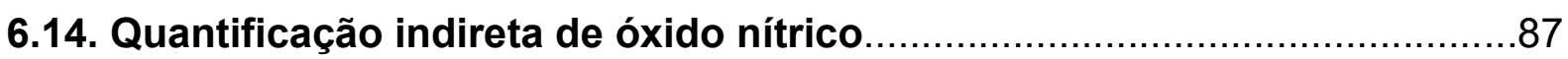

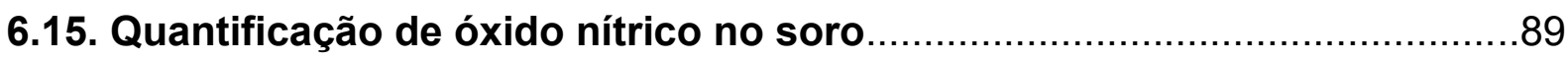

6.16. Análise das concentrações das substâncias reativas ao ácido

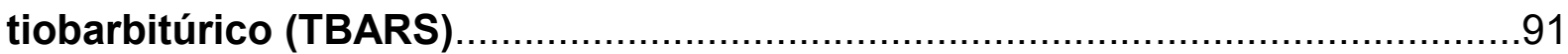

6.17. Avaliação plasmática da atividade da Superóxido Dismutase (SOD).......93

6.18. Determinação das concentrações plasmáticas do 8-isoprostano.............95

6.19. Quantificação da Glutationa (GSH) no plasma .......................................

6.20. Análise das concentrações das substâncias reativas ao ácido tiobarbitúrico (TBARS) no timo 99

6.21. Avaliação da atividade da Superóxido Dismutase (SOD) no timo 101

6.22. Detecção de $\mathrm{O}_{2}^{-}$pelo método de quimioluminescência da lucigenina e avaliação da expressão de NOX2 e SOD2 no timo 103

6.23. Níveis séricos de TGF- $\beta$, IL-2, IL-12, IL-17 e TNF- $\alpha$. 106

7. DISCUSSÃO

8. CONCLUSÃO 
INTRODUÇÃO 


\section{Introdução}

\subsection{Doença de Chagas}

A doença de Chagas ou tripanossomíase americana possui como agente etiológico o flagelado digenético Trypanosoma cruzi (T. cruzi), sendo considerada uma das mais sérias doenças parasitárias em humanos. Dados recentes indicam que aproximadamente sete milhões de pessoas encontram-se infectadas em todo o mundo, principalmente na América Latina, e cerca de 25 milhões de pessoas estão expostas ao risco de contraírem essa parasitose (OLIVERA et al., 2017; WHO Chagas disease (American trypanosomiasis).

A tripanossomíase americana foi descrita pelo médico Carlos Ribeiro Justiniano das Chagas em 1909. O pesquisador foi o primeiro e o único a descrever por completo uma doença parasitária, ou seja, seu agente etiológico, vetor, reservatórios, tanto doméstico quanto silvestre, os animais de laboratório suscetíveis à infecção, bem como as manifestações clínicas e epidemiológicas. (COURA; BORGES-PEREIRA, 2012; URBINA, 2009).

T. cruzi é um protozoário flagelado da ordem Kinetoplastidae, família Trypanosomatidae, que tem como formas evolutivas os tripomastigotas metacíclicos (forma infectante para o homem), epimastigotas (formas de multiplicação no vetor e em culturas de células), tripomastigotas sanguícolas (no sangue circulante) e amastigotas (formas imóveis que se multiplicam dentro das células do hospedeiro) (NUNES et al., 2013).

Em condições naturais, T. cruzi se encontrava restrito ao ambiente silvestre, circulando entre mamíferos no ambiente natural, por meio do inseto vetor. $\mathrm{O}$ ciclo, do tipo heteroxênico, tem início quando o inseto ingere as formas tripomastigotas circulantes, no momento da hematofagia em mamíferos infectados. Após multiplicação e metaciclogênese no tubo digestivo destes, são eliminados em suas fezes podendo infectar novos hospedeiros vertebrados (BERN, 2015; COURA; BORGES-PEREIRA, 2009; TEIXEIRA et al., 2012).

Dessa maneira, a partir do ano de 1975, foram adotadas medidas regulares de controle dos insetos vetores (URBINA, 2009). Tais medidas de controle da via vetorial permitiram que o Brasil obtivesse o Certificado Internacional de Eliminação da Transmissão da Doença de Chagas pelo inseto Triatoma infestans, conferida pela Organização PanAmericana da Saúde (FERREIRA; SILVA, 2006). No entanto, com a interrupção destas ações regulares da vigilância, existem relatos da 
capacidade de repovoamento do vetor, uma vez que esta espécie continua presente em países da América do Sul como Argentina, Bolívia, Paraguai e Peru (COURA, 2013). Além disso, existem outras espécies que se destacam como vetores do parasito, merecendo atenção especial o Triatoma brasiliensis, Triatoma pseudomaculata e Panstrongylus megistus (MUÑOZ-SARAVIA et al., 2012; RODRIGUES COURA, 2014).

Além da transmissão vetorial, existem outras formas de transmissão da doença, tais como transfusão sanguínea, via congênita (em qualquer momento da gestação), transplante de órgãos, secreções, acidentes em laboratórios ou ainda através da ingestão de alimentos e bebidas contaminadas com o parasita (CHATELAIN; KONAR, 2015; PEDRA et al., 2011).

Nas últimas décadas, em razão da migração de indivíduos infectados para locais onde não existe a transmissão vetorial, destaca-se a disseminação da doença para outros continentes e países não endêmicos (DIAS; COURA, 1997). Alguns países já apresentaram casos notificados da doença, tais como Espanha, Estados Unidos e Austrália. Dados indicam que em 2006, 3.8\% (3088) dos 80.522 imigrantes latino-americanos que foram para a Austrália estavam infectados por T. cruzi, dos quais 618 necessitaram de monitoramento médico como consequência da infecção.

A infecção aguda por $T$. cruzi é caracterizada por alta carga parasitária e proeminente infiltrado inflamatório presente em diversos tecidos do hospedeiro parasitado (KÖBERLE, 1968). Porém, na maioria dos casos os pacientes encontram-se assintomáticos, fato este que dificulta o diagnóstico neste período. Os sintomas mais comuns apresentados na fase aguda geralmente são inespecíficos, tais como febre, mal estar geral, linfodenopatia, hepatoesplenomegalia, insuficiência cardíaca, meningocefalite e linfocitose atípica (BERN, 2015; COURA; BORGESPEREIRA, 2010).

Dentre os sintomas específicos, destacam-se o Sinal de Romaña, caracterizado por um edema bipalpebral e unilateral, presente quando o parasita penetra pela conjuntiva ocular. Já o chagoma de inoculação, é uma inflamação aguda que acomete a derme e hipoderme no local de inoculação do parasita. A taxa de mortalidade durante a fase aguda da infecção geralmente é baixa, em torno de 2$8 \%$, atingindo em maior número crianças e pacientes imunossuprimidos (CHATELAIN; KONAR, 2015; MUÑOZ-SARAVIA et al., 2012; URBINA, 2015). No 
entanto, quando a forma de contágio acontece através da via oral, observam-se altas taxas de mortalidade (BERN, 2015; YOSHIDA; TYLER; LLEWELLYN, 2011).

Os indivíduos chagásicos podem permanecer por vários anos sem apresentar sintomas, em um período de latência, denominado forma indeterminada da doença. Nessa fase podemos observar como parâmetros diagnósticos, sorologia e testes parasitológicos positivos, ausência de sinais/sintomas, eletrocardiograma normal e coração, esôfago e cólon sem alterações anatomopatológicas (CHATELAIN; KONAR, 2015; MARIN-NETO; RASSI, 2009).

Após este período de latência, dependendo do tipo de cepa e estado imunológico do hospedeiro, dentre outros fatores, cerca de 20 a $30 \%$ dos pacientes infectados irão desenvolver as manifestações clínicas da doença de Chagas na fase crônica, podendo apresentar alterações cardíacas e/ou digestivas (TEIXEIRA et al., 2012; URBINA, 2015), sendo o acometimento cardíaco o mais prevalente no Brasil (PEDRA et al., 2011).

\subsection{Doença de Chagas e o Sistema Imune}

Embora os mecanismos envolvidos ainda não estejam completamente esclarecidos, estudos sugerem que a resistência do hospedeiro, bem como os diferentes graus de gravidade da doença de Chagas, são dependentes da eficiência da resposta imune do hospedeiro dirigida ao parasita. Portanto, a ação do sistema imunológico durante a fase aguda da infecção é essencial, a fim de controlar a replicação parasitária e, assim, limitar os danos teciduais durante a fase crônica. Componentes do sistema imune inato e adquirido, juntamente com as células como macrófagos, células natural killer (NK), células $\mathrm{T} \mathrm{CD}^{+}$e $\mathrm{CD}^{+}$, bem como a síntese de anticorpos por células $B$, conferem tal resistência durante a infecção por $T$. cruzi. (MARTINS et al., 2004).

A resposta imune inata do hospedeiro inicia com o recrutamento de diversos tipos celulares, em especial de macrófagos e células dendríticas, desencadeando uma série de interações moleculares. O reconhecimento de estruturas do parasita, denominadas PAMPS (pahtogen-associated molecular patterns) por diferentes receptores de reconhecimento padrão (PRRs - pattern recogmation receptors), tipo toll like-receptors (TLRs), é fundamental para o início e direcionamento adequado da imunidade adaptativa (JANEWAY; MEDZHITOV, 2002; TAKEDA; AKIRA, 2005). 
A apresentação de antígenos ocorre através do complexo de histocompatibilidade ( $\mathrm{MHC})$, presentes nas células da imunidade inata, e é o mecanismo de interação entre a imunidade inata e adaptativa. Entretanto, a completa ativação dos linfócitos requer a interação com moléculas coestimulatórias, provenientes de células apresentadoras de antígenos (APCs), durante 0 reconhecimento antigênico. Dentre elas, a molécula CD28, presente constitutivamente nos linfócitos $T$, interage com as moléculas CD80 (B7-1) e CD86 (B7-2), expressa indutivamente na superfície das APCs (FELONATO et al., 2010).

Ao interagir com macrófagos, o parasita induz a produção de Interleucina-12 (IL-12), citocina que atua sobre as células NK e estimula a diferenciação de linfócitos T auxiliares $\mathrm{CD}^{+}$em células T helper 1 (Th1) produtoras de interferon gamma (IFNy) (ALIBERTI et al., 1996). O IFN-y, por sua vez, agirá sobre os macrófagos, ativando-os e desencadeando a expressão da enzima óxido nítrico sintase induzida (iNOS), com consequente produção de óxido nítrico (NO). O NO é formado através da reação de conversão da L-arginina em L-citrulina pela atividade catalítica da iNOS, promovendo o controle da replicação parasitária, em razão do seu importante papel microbicida (BORGES et al., 2009).

Diferentes estímulos podem induzir a expressão de iNOS tais como IL-1, INF$\mathrm{Y}$, TNF- $\alpha$, bem como os produtos bacterianos (LPS), os quais qual aumentam a sua expressão. No entanto, os glicocorticóides, IL-4, IL-10 e TGF- $\beta$ dentre outros, são responsáveis por sua inibição (MAYER; HEMMENS, 1997).

A mobilização efetiva da resposta imune durante a fase aguda da doença de Chagas contribui para a redução significativa da carga parasitária sanguínea e diminuição dos ninhos teciduais. Entretanto, tal resposta não é capaz de eliminar totalmente o parasita do organismo do hospedeiro, contribuindo para o aparecimento das manifestações da fase crônica da infecção (BUSTAMANTE et al., 2007).

\subsection{Radicais livres e Estresse oxidativo}

Os radicais livres podem ser definidos como átomos ou moléculas que possuem um ou mais elétrons desemparelhados no seu orbital mais externo, conferindo uma alta reatividade por esta instabilidade eletrônica (CAROCHO; FERREIRA, 2013; HALLIWELL, 2007; UTTARA et al., 2009). As espécies reativas de oxigênio (EROs), são originadas pelo desvio de elétrons da cadeia respiratória durante o processo de produção de adenosina trifosfato (ATP), que ocorre nas 
mitocôndrias ou ainda pela oxidação da nicotinamida adenina dinucleotídeo fosfato (NADPH) por enzimas NADPH oxidases (NOXs), responsáveis por catalisar a produção de ânion superóxido $\left(\mathrm{O}_{2}^{-}\right)$pela redução do oxigênio $\left(\mathrm{O}_{2}\right)$, usando o NADPH ou NADH como doadores de um elétron: $2 \mathrm{O}_{2}+\mathrm{NADPH} \rightarrow 2 \mathrm{O}_{2}^{-}+\mathrm{NADP}^{+}+\mathrm{H}^{+}$ (BABIOR, 2004; PARAVICINI; TOUYZ, 2008).

$\mathrm{O}_{2}^{-}$pode atuar como agente oxidante, sendo reduzido a peróxido de hidrogênio $\left(\mathrm{H}_{2} \mathrm{O}_{2}\right)$, ou como agente redutor, doando o seu elétron extra ao óxido nítrico (NO) para formar peroxinitrito (ONOO-). O ONOO- formado é capaz de oxidar proteínas, lipídios e ácidos nucléicos, provocando diversos danos celulares (BECKMAN; KOPPENOL, 1996).

As $\mathrm{NAD}(\mathrm{P}) \mathrm{H}$ oxidases foram descritas inicialmente como enzimas expressas em células fagocítárias, importantes para a imunidade inata e defesa do hospedeiro. A descoberta de homólogos indicou a existência de uma família de $N A D(P) H$ oxidases, que são designados como a família Nonphagocytic NADPH Oxidase (NOX), que compreendem sete membros, caracterizados pela subunidade catalítica que utilizam. Compreendem a NOX1, NOX2, NOX3, NOX4 (originalmente chamada Renox - renal oxidase - oxidase renal), NOX5 e DUOX1 e DUOX2. Tais enzimas são expressas em diferentes tecidos, desempenhando ações biológicas diversificadas (PARAVICINI; TOUYZ, 2008; TOUYZ; BRIONES, 2011).

Em oposição ao excesso na produção de EROs, e visando proteger o organismo da ação destes mediadores, são produzidas várias enzimas, que compõe o sistema de defesa antioxidante, e que podem inativar tais espécies reativas. São exemplos, a catalase (CAT), glutationa peroxidase (GPx) e superóxido dismutase (SOD) (CERON et al., 2014; GONGORA et al., 2006; TAJIMA et al., 2009). A SOD, considerada a primeira linha de defesa contra as EROs, é responsável por catalisar a dismutação de ânion superóxido $\left(\mathrm{O}_{2}^{-}\right)$em oxigênio e peróxido de hidrogênio $\left(\mathrm{H}_{2} \mathrm{O}_{2}\right)$. Ela age como um antioxidante enzimático, enquanto a GPx utiliza como substrato a glutationa reduzida (GSH), levando a formação da glutationa oxidada (GSSG). A GPx converte $\mathrm{H}_{2} \mathrm{O}_{2}$ em água, sendo considerada um importante componente do sistema antioxidante não enzimático (LI; HORKE; FÖRSTERMANN, 2013).

Frente a diversos processos infecciosos, as EROs são formadas em grandes quantidades no interior de células fagocíticas na tentativa de controlar a infecção. Porém, o quadro de estresse oxidativo é estabelecido quando ocorre um intenso 
desequilíbrio entre a formação dos radicais livres e a capacidade do organismo em eliminá-las (HALLIWELL, 2007). Na doença de Chagas, a formação acentuada destas espécies ocasiona a destruição tecidual, estimulação de mediadores inflamatórios e danos secundários às mitocôndrias ("Oxidative Stress in Human Infectious Diseases - Present and Current Knowledge About Its Druggability | IntechOpen"). Ainda, um acúmulo de radicais livres também pode ser obsevado durante o processo de envelhecimento, o qual é seguido por danos em vários tecidos e órgãos (BECKMAN; AMES, 1998), sendo a base da teoria dos radicais livres no envelhecimento (WEl et al., 2005).

Quando ocorre um aumento das EROs e/ou uma dimuição da capacidade antioxidante, essas moléculas oxidantes interagem com as biomoléculas do organismo, como fosfolipídios, proteínas e ácidos nucléicos, levando às disfunções celulares e, consequentemente, morte celular. Todos os componentes celulares são suscetíveis à ação das EROs frente ao estresse oxidativo, porém a membrana é um dos mais atingidos em decorrência da peroxidação lipídica, o que acarreta alterações na sua estrutura e permeabilidade (FERREIRA; MATSUBARA, 1997). Dessa forma, os danos celulares causados pela oxidação podem ser avaliados através da quantificação de produtos da peroxidação lipídica (YELINOVA et al., 1996), tais como o malondialdeído (MDA), ou 8-iso prostaglandina $F_{2 \alpha}$ (8isoprostano), substância formada em decorrência da oxidação não enzimática de ácido araquidônico.

\subsection{Senescência e Imunossenescência}

Os países industrializados possuem em sua população cerca de $20 \%$ de indivíduos com mais de 60 anos e a proporção de indivíduos com idade maior que 85 anos cresce seis vezes mais rápido do que a população em geral. Este aumento da população idosa foi acelerado nos últimos 10 anos, gerando uma grande preocupação econômica em relação à área da saúde, uma vez que a maioria destes indivíduos necessita constantemente de atendimento médico (WICK et al., 2000).

No Brasil, as projeções demográficas estimam que no período entre $2000 \mathrm{e}$ 2050 a proporção de idosos na população deve subir de 5,1\% para 14,2\%. Desta forma, em 2025 , o país passará de $16^{\circ}$ para $6^{\circ}$ lugar entre os países com maior 
número de idosos, com mais de 30 milhões de indivíduos acima dos 60 anos (CHAIMOWICZ, 1997).

A atividade do sistema imune, assim como a maior parte das funções fisiológicas, diminui com a idade, fato que tem sido utilizado como base teórica para explicar o processo de envelhecimento (AGOSTINHO, 2004). O termo imunossenescência se refere às disfunções do sistema imune relacionadas com a idade, que contribuem para uma maior incidência de doenças infecciosas, parasitárias, autoimunes e crônico-degenerativas (SANSONI et al., 2008; TARAZONA et al., 2002). Esse processo é caracterizado por alterações quantitativas e/ou qualitativas nos componentes celulares e moleculares, os quais levam a um estado de inadequada atividade do sistema imune (AW; SILVA; PALMER, 2007).

Em oposição, outros estudos indicam que a imunossenescência não é um declínio progressivo e inevitável de todo o sistema imune (SANSONI et al., 2008). Ela está relacionada à melhora linear na sobrevivência (DE MARTINIS MASSIMO et al., 2005), resultando de um processo de remodelamento contínuo, em que várias funções estão reduzidas, e outras permanecem inalteradas ou até mesmo aumentadas (FRANCESCHI et al., 1996).

Embora os mecanismos envolvidos nas complexas alterações que ocorrem com o progressivo envelhecimento ainda não estejam completamente esclarecidos, alguns autores destacam que a manutenção do estado próinflamatório crônico (FRANCESCHI et al., 1996) tem importante participação neste processo. Portanto, o aumento na produção de citocinas, como as IL-6, IL-7, TNF- $\alpha$ e outros fatores solúveis da inflamação, podem ser considerados prognósticos de morbidade e mortalidade no idoso (SANSONI et al., 2008).

Com o envelhecimento, algumas funções dos neutrófilos como quimiotaxia, produção de ânion superóxido e apoptose estão alteradas. Isso pode ser decorrente, por exemplo, de alterações na sinalização de receptores, desencadeando declínios nas atividades fagocíticas e bactericidas destas células no local da infecção (PAWELEC, 2007). A morte celular programada ou processo apoptótico de neutrófilos e macrófagos podem ocorrer de forma prematura, contribuindo para a reduzida atividade fagocitária observada no idoso (CRIGHTON; PUPPIONE, 2006). Segundo Fulop e colaboradores (1997), estas células senescentes são incapazes de permanecer vivas no local da infecção por tempo suficiente para desempenhar 
atividade fagocitária por ter uma menor resposta às citocinas que normalmente prolongam sua sobrevida (FÜLÖP et al., 1997).

Além disso, os macrófagos apresentam menor capacidade de quimiotaxia e de produção de agentes oxidantes, bem como, diminuição da quantidade de precursores macrofágicos/monocíticos na medula óssea e a produção de moléculas de sinalização oriundas dessas células (SOLANA; PAWELEC; TARAZONA, 2006).

À medida que envelhecemos, ocorre um aumento da quantidade de células NK embora sua atividade esteja diminuída. A resposta de células NK às citocinas, por exemplo, se encontra reduzida, o que resulta no declínio da citotoxicidade celular e da síntese de citocinas e quimiocinas (KOCH et al., 2006).

Com relação às células dendríticas, consideradas elo importante entre a imunidade inata e a adaptativa, estudos apontam que a produção de citocinas não sofre alterações significantes com o envelhecimento, embora as células dos idosos secretem mais IL-6 e TNF- $\alpha$ (PAWELEC, 2007). Por outro lado, há relatos de que as células dendríticas apresentem falha na geração da resposta anti-inflamatória, o que pode explicar o paradoxo do aumento da inflamação associada com o envelhecimento humano (VASTO; MALAVOLTA; PAWELEC, 2006).

Uma das principais alterações do sistema inume diante da senescência é a redução do número de células T naive e aumento dos clones de memória (VASTO; MALAVOLTA; PAWELEC, 2006). Outra alteração na resposta imune é a mudança na relação entre células Th1 e Th2, ocorrendo um aumento nas células Th2 com simultâneo decréscimo das Th1. Paralelamente, ocorre um declínio na síntese de IL2, sendo considerado um importante fator na imunossenescência (NOVAES et al., 2005). Outras alterações incluem a redução de moléculas coestimuladoras, as deficiências na produção dos linfócitos $B$ e sinalização do receptor destas células e a diminuição da afinidade de imunoglobulinas (AW; SILVA; PALMER, 2007). 
JUSTIFICATIVA 


\section{JUSTIFICATIVA}

Apesar de todo o avanço científico nas últimas décadas no sentido de desvendar os processos imunes do hospedeiro e a forma de evasão do parasita, a doença de Chagas ainda é um importante problema em saúde pública. A expectativa de vida no Brasil tem aumentado a cada ano e esse crescimento permite o surgimento de uma população idosa em risco de contrair a doença de Chagas. De fato, uma importante carga da infecção por $T$. cruzi foi reportada entre indivíduos idosos em áreas endêmicas do país, em que a transmissão da doença havia sido interrompida há mais de vinte anos. Entretanto, novas formas de contaminação como a ingestão de alimentos contendo triatomíneos infectados ocasionaram o aparecimento de surtos agudos e extremamente patogênicos, como a ingestão de caldo de cana e açaí contaminados (YOSHIDA, 2009). Dessa forma, a população idosa corre um risco maior, pois o parasita encontrará nesses organismos condições favoráveis para o seu estabelecimento em consequência do estado fragilizado da resposta imune dos indivíduos senis.

$\mathrm{Na}$ literatura existem poucos estudos que abordam as alterações ocasionadas pela doença de Chagas em pacientes idosos e a maioria trata dos aspectos clínicos da doença (RESENDE et al., 2003). É, portanto, de fundamental importância voltar nossa atenção para as consequências que a doença de Chagas poderá trazer a estes indivíduos. A busca por biomarcadores que possibilitem o estabelecimento de um prognóstico positivo ou negativo de imunossenescência e a sua associação com o padrão de resposta imune é fundamental em uma sociedade que mostra sinais de inversão da pirâmide etária, possibilitando a consequente organização de programas voltados ao bem estar da população idosa.

A proposta deste trabalho foi inédita, visto não se encontrar disponíveis trabalhos que descrevam as alterações funcionais da resposta imune ratos Wistar senis e infectados. Com o presente estudo, buscamos avançar na compreensão dos mecanismos celulares e moleculares envolvidos nas alterações da imunidade ao longo da vida e seus reflexos frente à doença de Chagas. Os resultados desse trabalho, bem como a análise do envolvimento do processo de apoptose, estresse oxidativo e inflamação durante a infecção será de grande importância na elaboração de futuras estratégias de intervenção imune - terapêutica que visem proporcionar ao hospedeiro um direcionamento eficiente da resposta imune durante a infecção, minimizando os efeitos deletérios do envelhecimento associados a ela. 
OBJETIVOS 


\section{OBJETIVOS}

O objetivo principal deste trabalho foi analisar a resposta imune em ratos Wistar senescentes, infectados pela cepa $Y$ de $T$. cruzi, utilizando os seguintes parâmetros:

- Quantificação de mediadores do sistema imune - citocinas (TGF- $\beta$, IL-2, IL-12, IL17 e TNF- $\alpha$ ) e óxido nítrico;

- Análise fenotípica das populações celulares, incluindo macrófagos, células dendríticas, células NK, NKT e os demais subtipos de linfócitos;

- Análise da apoptose de células esplênicas e timócitos;

- Avaliação do estresse oxidativo, com a quantificação de TBARS, 8-isoprostano, enzimas antioxidantes, ânions superóxidos e expressão de NOX2 e SOD2;

- Quantificação de Corticosterona. 
MATERIAIS E MÉTODOS 


\section{MATERIAIS E MÉTODOS}

\subsection{Animais utilizados}

Foram utilizados ratos machos Wistar, na fase adulta jovem (5 semanas), pesando \pm 250 gramas e na fase senil (18 meses) (ANDREOLLO et al., 2012), \pm 600 gramas, provenientes de uma colônia mantida no Biotério Central da Universidade de São Paulo, Campus de Ribeirão Preto. Os animais senis foram àqueles utilizados pelo biotério para o acasalamento, possuindo idade de aproximadamente 6 meses. O alojamento e envelhecimento (até 18 meses) dos mesmos foram no Biotério I da Faculdade de Ciências Farmacêuticas de Ribeirão Preto, sendo mantidos a temperatura de $23 \pm 2^{\circ} \mathrm{C}$, em ciclo claro/escuro $12 / 12$ horas, com livre acesso à água e ração. Os animais foram mantidos em 2 por caixa com medida de $37 \times 31 \times 15 \mathrm{~cm}$, totalizando $1147 \mathrm{~cm}^{2}$, que foi limpa duas vezes na semana. Todos os experimentos foram realizados no Laboratório de Parasitologia do Departamento de Análises Clínicas Toxicológicas e Bromatológicas da Faculdade de Ciências Farmacêuticas de Ribeirão Preto (FCFRP - USP). O projeto foi avaliado pelo comitê de ética para o uso de animais do Campus da USP de Ribeirão Preto (CEUA) e aprovado sob o protocolo n. ${ }^{\circ}$ 2014.1.928.53.0. Para cada dia de experimento, foram utilizados 6 animais por grupo.

\subsection{Grupos Experimentais}

Os animais foram divididos em quatro grupos: dois grupos controle, compostos de animais jovens e senis não infectados, e os outros dois grupos, compostos por animais jovens e senis infectados pela cepa $Y$ de $T$. cruzi. Foram realizadas três repetições dos experimentos para melhor avaliação dos resultados.

Tabela 1. Grupos experimentais

\begin{tabular}{cc}
\hline Grupo Controle & Grupo infectado pela cepa Y de $T$. cruzi \\
\hline Controle jovem (CJ) $n=5$ & Infectado jovem (IJ) $n=5$ \\
\hline Controle senil (CS) $n=5$ & Infectado senil (IS) $n=5$ \\
\hline
\end{tabular}

\subsection{Rotina Experimental}

Os experimentos foram realizados no $9^{\circ}$ e $16^{\circ}$ dias após o inóculo infectante, tanto para o grupo jovem quanto para os senis. A escolha destes dias foi baseada 
no perfil da curva parasitêmica, em que o pico de parasitemia para ratos ocorre, normalmente, entre $7^{\circ}$ e $9^{\circ}$ dias, após o inóculo (LOPES; JÚNIOR, 2010).

\subsection{Infecção}

Os animais foram inoculados intraperitonealmente $0,1 \mathrm{~mL}$ com $1.0 \times 10^{5}$ formas tripomastigotas da cepa Y de T.cruzi ("SciELO Brasil - www.scielo.br", [s.d.]). Esta cepa foi primeiramente isolada por Silva \& Nussenzweig (1953), por meio de xenodiagnóstico realizado em uma paciente na fase aguda da infecção. Desde então, vem sendo mantida em camundongos Swiss não isogênicos, através de repiques semanais de sangue infectado.

\subsection{Eutanásia dos animais e coleta de sangue}

Os animais foram previamente anestesiados com Tribromoetanol 2,5\%, na dose de $250 \mathrm{mg} / \mathrm{Kg} /$ peso do animal, administrado intraperitonealmente (i.p.) (CALDEIRA; FRANCI, 2000), para evitar que outras manipulações aumentem o efeito do estresse e possam interferir nos parâmetros analisados e posteriormente submetidos à decapitação, utilizando guilhotina. A coleta de sangue foi realizada após a morte dos animais, sendo coletado cerca de $2 \mathrm{~mL}$ em tubo plástico contendo $200 \mu \mathrm{L}$ de Heparina sódica (1 mL:5.000 U.I.), para quantificação de parasitas e macrófagos peritoneais e $2 \mathrm{~mL}$ de sangue em outro tubo de plástico sem anticoagulante para análises imunológicas.

\subsection{Quantificação de parasitas}

Após a morte dos animais, foi realizada a quantificação de parasitas, utilizando o método de Brener (BRENER, 1962), que consiste em colocar uma alíquota de $5 \mu \mathrm{L}$ de sangue em lâmina, cobrindo-a com lamínula de 22×22 mm. Determina-se o número de parasitas em 50 campos microscópicos. O número encontrado é multiplicado por um fator, calculado para cada microscópio e lente objetiva, e considera o número de campos microscópicos existentes na área da lamínula.

\subsection{Contagem global de macrófagos peritoneais}

Após a eutanásia, os animais foram mantidos em câmara asséptica de fluxo laminar e fixados em decúbito dorsal em suporte de dissecção. A parede abdominal 
foi exposta, rebatendo-se a pele da região. As células peritoneais foram coletadas por meio de injeção de $5 \mathrm{~mL}$ de RPMI, pH 7,2 estéril, gelado, seguido de massagem peritoneal. Essas células foram então lavadas e submetidas à centrifugação a 1800 rpm por 10 min a $4^{\circ} \mathrm{C}$. A seguir foram ressuspendidas em $1 \mathrm{~mL}$ de RPMI-1640, para contagem das células viáveis em câmara de Neubauer, realizada através da coloração com solução de Azul de Trypan (0,4\%).

\subsection{Citometria de fluxo}

\subsubsection{Caracterização fenotípica e funcional de macrófagos e células dendríticas}

Após a contagem dos macrófagos, a concentração foi ajustada para $2 \times 10^{6}$ células/poço, acondicionadas em tubos para citometria. As suspensões celulares foram primeiramente incubadas com $120 \mu \mathrm{L}$ de formaldeído $4 \%$ por $10 \mathrm{~min}$, no gelo. Posteriormente, lavadas com $500 \mu \mathrm{L}$ de PBS, centrifugadas a $8000 \mathrm{rpm}, 4^{\circ} \mathrm{C}$, por 1 min. Em seguida, foram incubadas com 50 $\mathrm{L}$ de Fcblock (BD PharMingen), por 20 min a $4^{\circ} \mathrm{C}$. Após a incubação, as células foram novamente lavadas com $500 \mu \mathrm{L}$ de PBS, centrifugadas a $8000 \mathrm{rpm}, 4^{\circ} \mathrm{C}$ por $1 \mathrm{~min}$ e o sobrenadante descartado. Em seguida, foi realizada a marcação das células com anticorpos monoclonais antiCD11bc- PE-CyTM, anti macrophage subset-PE, anti-CD80 PE, anti-CD86 FITC, e anti-RT1B-PercP para determinação das sub-populações celulares. Todos os anticorpos foram obtidos da BD Bioscience PharMingen® (Tabela 3).

Após a realização da marcação com os anticorpos, as amostras foram e ressuspendidas em $150 \mu \mathrm{L}$ de formaldeído $1 \%$ e realizada a leitura através do Citômetro BD FACS-Canto (BD Biosciences). A análise dos resultados foi executada usando o programa FACSDiva (BD).

\subsubsection{Análise fenotípica das populações celulares nas células esplênicas}

O baço foi removido cirurgicamente após a retirada do lavado peritoneal, e as células esplênicas obtidas por maceração em peneiras de aço inox com porosidade em $4 \mathrm{~mL}$ de meio de RPMI 1640. A análise fenotípica celular, utilizando os marcadores apresentados na tabela 2 a seguir, foi realizada por citometria de fluxo, baseada em anticorpos monoclonais marcados com substâncias fluorescentes (Tabela 3), dirigidos contra antígenos de superfície dessas células. 
Tabela 2. Marcadores celulares que foram analisados

\begin{tabular}{ll}
\hline Descrição & Marcadores Celulares \\
\hline Marcadores de célula T auxiliar e citotóxica & CD3, CD4, CD8 \\
Moléculas coestimuladoras & CD28, CD80, CD86 \\
Marcadores de célula NK e NKT & CD3, CD161 \\
Marcadores de célula T reguladora & CD4, CD25, FOXP3 \\
Marcador de adesão celular & CD11a \\
\hline Marcador de macrófago & Macrophage subset \\
Marcador de célula B & CD45RA \\
Marcador de ativação celular & RT1B \\
Marcador de célula dendrítica & CD11bc \\
Marcador do envelhecimento & CD28 \\
\hline
\end{tabular}

Tabela 3. Anticorpos monoclonais que foram utilizados na análise fenotípica das células esplênicas e timócitos

\begin{tabular}{lll}
\hline Anticorpo & Clone & Concentração \\
\hline Anti-CD3 - APC/FITC & 1F4 & $0,2 \mathrm{mg} / \mathrm{mL} ; 0,5 \mathrm{mg} / \mathrm{mL}$ \\
Anti-CD4 - PE/PECy7 & OX-38/OX-35 & $0,2 \mathrm{mg} / \mathrm{mL}$ \\
Anti-CD8 - PercP & OX-8 & $0,2 \mathrm{mg} / \mathrm{mL}$ \\
Anti-CD11a - FITC & WT.1 & $0,5 \mathrm{mg} / \mathrm{mL}$ \\
Anti-CD11bc - PECy7 & OX-42 & $0,2 \mathrm{mg} / \mathrm{mL}$ \\
Anti-CD25 - FITC/PE & OX-39/ & $0,5 \mathrm{mg} / \mathrm{mL}$ \\
Anti-CD28 - PE & JJ319 & $0,2 \mathrm{mg} / \mathrm{mL}$ \\
Anti-CD45RA - PE & OX-33 & $0,2 \mathrm{mg} / \mathrm{mL}$ \\
Anti-CD80 - PE & $3 \mathrm{H} 5$ & $0,2 \mathrm{mg} / \mathrm{mL}$ \\
Anti-CD86 - FITC & $24 \mathrm{~F}$ & $0,5 \mathrm{mg} / \mathrm{mL}$ \\
Anti-CD161 - FITC & $10 / 78$ & $0,5 \mathrm{mg} / \mathrm{mL}$ \\
Anti-RT1B - PercP & OX-6 & $0,2 \mathrm{mg} / \mathrm{mL}$ \\
Anti-Macrophage subset & - HIS36 & $0,2 \mathrm{mg} / \mathrm{mL}$ \\
PE & & \\
\hline
\end{tabular}




\subsubsection{Caracterização de células $T$ reguladoras $T \mathrm{CD}^{+} \mathrm{CD} 25^{+}$através da expressão do fator de transcrição FOXP3}

Após a obtenção das células esplênicas, alíquotas de $200 \mu \mathrm{L}$, forma adicionadas a tubos apropriados. Foi realizada a marcação de proteínas de membrana com a adição dos anticorpos monoclonais anti-CD3 FITC, anti CD4 PECy7, e anti CD25 PE (obtidos da BD Pharmigen ${ }^{\circledR}$ ). Para a marcação do anticorpo para o fator de transcrição intracelular FOXP3 (Tabela 3), (diluído 1/50, Alexa Fluor 647, em solução de Perm Wash-eBioscience, San diego, CA, EUA-) foi utilizado o Kit da ebioscience. A leitura foi realizada em citômetro de fluxo (FACSCanto/Becton \& Dickson). A análise dos resultados foi executada usando o programa FACSDiva (BD).

\subsubsection{Detecção do processo de apoptose}

Para a caracterização dos diferentes estágios de apoptose as células esplênicas e tímicas obtidas foram lavadas com PBS e centrifugadas a 1800 rpm por 10 minutos, e o sobrenadante foi descartado. Adicionou-se às suspensões celulares $100 \mu \mathrm{L}$ da solução de tampão de ligação da Anexina-V (Annexin Binding Buffer), e $1 \mu \mathrm{L}$ de cada marcador, anexinaV-FITC e de iodeto de propídio (PI) (Tabela 3), (provenientes da BD Biosciences, EUA). As amostras foram incubadas por 15 minutos à temperatura ambiente, acondicionados a $4^{\circ} \mathrm{C}$ e ao abrigo da luz até $\mathrm{O}$ momento da análise no citômetro de fluxo.

\subsubsection{Análise fenotípica das populações celulares nos timócitos}

O timo foi removido cirurgicamente e os timócitos obtidos por maceração com o auxílio de peneiras para cultura celular (Cell strainer- BD Biosciences). e $4 \mathrm{~mL}$ de meio de RPMI 1640. Foi realizada a análise fenotípica celular, utilizando os anticorpos anti CD3 APC, anti CD4 PeCy7, anti CD8 PercP, anti CD44 FitC e anti CD25 PE (Tabela 3), dirigidos contra antígenos de superfície das células correspondentes.

\subsection{Avaliação do estresse oxidativo}

\subsubsection{Quantificação indireta de óxido nítrico}

A quantificação de óxido nítrico foi analisada de acordo com a técnica de Reação de Griess, sendo distribuídos $100 \mu \mathrm{L}$ da suspensão do lavado peritoneal, em 
placa de 96 poços, contento $5 \times 10^{6}$ células/poço. Foram adicionados $100 \mu \mathrm{L}$ de lipopolissacarídeo de Escherichia coli $(10 \mu \mathrm{g} / \mathrm{mL}$ ) (LPS - E.coli, sorotipo 026:B6, Sigma USA) nos poços estimulados. A placa foi levada à estufa contendo $5 \%$ de $\mathrm{CO}_{2}$, durante 48 horas, a $37^{\circ} \mathrm{C}$. Após este período, a placa foi submetida à centrifugação a $1500 \mathrm{rpm}, 23^{\circ} \mathrm{C}$, durante $4 \mathrm{~min}$. $100 \mu \mathrm{L}$ do sobrenadante foi recolhido e transferido para outra placa de 96 poços. Em seguida, foi adicionado igual volume de reagente de Griess, ou seja, $50 \mu \mathrm{L}$ de sulfanilamida $1 \%$ (Sigma) e $50 \mu \mathrm{L}$ de N-1-naftiletilenodiamina 0,1\% (Sigma), por um período de incubação de 10 min cada, diluídos em solução de ácido fosfórico 5\%, permitindo a revelação da reação por meio de leitor de microplacas, utilizando filtro de $540 \mathrm{~nm}$. A curva padrão de $200 \mu \mathrm{M}$ a $6 \mu \mathrm{M}$ foi realizada utilizando nitrito de sódio (TERENZI et al., 1995).

\subsubsection{Quantificação de óxido nítrico no soro}

A produção de NO foi determinada através da quantificação total de nitrito/nitrato (NO2//NO3-) pela reação de Griess. Os níveis totais de NO2- que foram convertidos de $\mathrm{NO}^{-}$foram determinados em amostras de soro. $\mathrm{O} \mathrm{NO3}{ }^{-}$foi convertido em NO2- por incubação de $0,01 \mathrm{~mL}$ de nitrato redutase (Aspergillus) e $0,01 \mathrm{~mL}$ de NADPH $(1 \mathrm{mM})$, durante $30 \mathrm{~min}$ a $37^{\circ} \mathrm{C}$. Os níveis $\mathrm{NO}^{-}$foram determinados através da leitura em espectrofotômetro a $540 \mathrm{~nm}$, após a adição dos reagente de Griess, ou seja, $50 \mu \mathrm{L}$ de sulfanilamida 1\% (Sigma) e $50 \mu \mathrm{L}$ de N-1naftiletilenodiamina 0,1\% (Sigma), por um período de incubação de 10 min cada, diluídos em solução de ácido fosfórico $5 \%$.

\subsubsection{Análise das concentrações das substâncias reativas ao ácido tiobarbitúrico (TBARS) no plasma, no timo e no tecido cardíaco}

A avaliaçao de espécies reativas ao ácido tiobarbitúrico é um método bem estabelecido para a identificação e monitoramento da peroxidação lipídica, indicador de estresse oxidativo em células, tecidos e fluidos (YAGI, 1998). O ensaio (TBARS assay kiy, Cayman Chemical Company, EUA, Cat. $\left.n^{\circ} 10009055\right)$ consiste na medida colimétrica (comprimento de onda de 530-540 nm) do complexo formado pela reação do MDA (malondialdeido - ácido graxo poli-insaturado, produto de peroxidação lipídica) e TBA (ácido tiobarbitúrico) sob alta temperatura $\left(90-100{ }^{\circ} \mathrm{C}\right.$ ) em meio ácido. Valores maiores de TBARS, expressos em $\mathrm{nmol} / \mathrm{mL}$, são alcançados 
proporcionalmente à presença de maior quantidade de lipídios poliinsaturados. Os valores de TBARS foram expressos em $\mathrm{nmol} / \mathrm{ml}$ de plasma ou $\mathrm{nmol} / \mathrm{mg}$ de proteína.

\subsubsection{Avaliação plasmática da atividade da Superóxido Dismutase (SOD) no plasma e no timo}

O timo foi homogeneizado em tampão HEPES (20 mmol/L), pH 7,2 contendo $1 \mathrm{mmol} / \mathrm{L}$ de EGTA, $210 \mathrm{mmol} / \mathrm{L}$ de manitol e $70 \mathrm{mmol} / \mathrm{L}$ de sacarose, sendo o homogenato final centrigado a $1.500 \mathrm{~g}$ por 5 minutos a $4^{\circ} \mathrm{C}$, a fim de obter 10 $\mu \mathrm{L}$ de sobrenadante para a realização do teste. O mesmo volume de amostra de plasma foi utilizado. O ensaio (Superoxide Dismutase assay Kit, Cayman Chemical Company, EUA, Cat. $\mathrm{n}^{\circ}$ 706002) utiliza o sal tetrazólio para a detecção de radicais superóxido gerados pela xantina oxidase e hipoxantina, sendo que a reação gera o produto cromogênico, corante de formazan, com absorbância monitorada a 440-460 $\mathrm{nm}$. Os resultados foram expressos em \% de inibição/mL de plasma ou \% de inibição/mg de proteína, ou seja, a capacidade da SOD em inibir a reação do $\mathrm{O}_{2}{ }^{-}$ com o tetrazólio.

\subsubsection{Determinação das concentrações plasmáticas do 8-isoprostano}

As concentrações de 8-isoprostano foram determinadas de acordo com as instruções do kit específico (Cayman Chemical Company, Ann Arbor, Michigan, EUA - 516.351). Resumidamente, $50 \mu \mathrm{L}$ de plasma foram adicionados à placa de ELISA para iniciar a competição com o marcador de 8-isoprostano (8-isoprostano conjugado com a acetilcolinesterase), por meio de anticorpos específicos de ligação. Posteriormente, foi adicionado o anticorpo secundário de ligação (anti lgG de coelho). Após o acoplamento, foi adicionado o reagente Ellman contendo acetilcolina, a qual reage com o marcador 8-isoprostano ligado ao anticorpo. $O$ produto da reação tem uma cor amarela. As concentrações do 8-isoprostano foi determinado por absorbância $(450 \mathrm{~nm})$ e os valores expressos em pg/mL de plasma.

\subsubsection{Quantificação da Glutationa (GSH) (glutationa reduzida) no plasma}

Foi adicionado $100 \mu \mathrm{L}$ de ácido tricloroacético (TCA, 12,5\%), no plasma e este permaneceu no gelo por 30 minutos. Em seguida, a amostra foi centrifugada a $3000 \mathrm{rpm}$ por 15 minutos a $4^{\circ} \mathrm{C}$. A montagem da placa foi realizada pela adição de $30 \mu \mathrm{L}$ da amostra e $270 \mu \mathrm{L}$ de Tris HCL. A cada poço foi incorporado $5 \mu \mathrm{L}$ de ácido 
5,5-ditiobis (2-nitrobenzóico) (DDTNB; 3,96 mg DTNB em $1 \mathrm{~mL}$ de metanol), reagente que, quando em contato com o grupo $\mathrm{SH}$ - tiol dos grupos sulfidrílicos, produz coloração amarela, lida espectrofotometricamente a $415 \mathrm{~nm}$. Os valores individuais foram interpolados em uma curva padrão de GSH e expressos em $\mu \mathrm{g}$ de $\mathrm{GSH} / \mathrm{mL}$ de plasma.

\subsubsection{Detecção de $\mathrm{O}_{2}^{-}$pelo método de quimioluminescência da lucigenina no timo}

Amostras de timo foram homogeneizadas em tampão fosfato $\mathrm{pH}$ 7,4 (20 mM de $\mathrm{KH}_{2} \mathrm{PO}_{4}, 1 \mathrm{mM}$ de EGTA e $150 \mathrm{mM}$ de sacarose). A reação foi iniciada pela adição de $\operatorname{NAD}(\mathrm{P}) \mathrm{H}(0,1 \mathrm{mM})$ a uma suspensão (volume final de $250 \mu \mathrm{l}$ ) contendo amostra de aorta (50 $\mu \mathrm{L}$ do homogenato), lucigenina (5 $\mu \mathrm{M})$ e tampão fosfato $\mathrm{pH} 7,4$. Os valores de unidades relativas de luz (URL) foram obtidos a partir da subtração do valor basal (obtido por uma medida inicial da amostra, tampão fosfato mais lucigenina) pelo valor obtido da análise após adição de NADPH. Foram realizados 30 ciclos de leitura, utilizando-se o luminômetro Orion II- Microplate Luminometer MPL4 (Berthold detection systems, Pforzheim, Alemanha). Os resultados foram normalizados pela concentração proteica de cada amostra e expressos como Unidades Relativas de Luz (URL)/mg de proteína (YOGI et al., 2010).

\subsubsection{Avaliação da expressão enzimática da NOX2 e SOD2 no timo de ratos Wistar pela técnica de Western Blotting}

Trinta $\mu \mathrm{g}$ de proteína total de amostras de timo foram submetidas à eletroforese em gel de poliacrilamida (10\%) por 1 hora e 20 minutos a $150 \mathrm{~V}$ em aparelho para mini-gel (mini Protean III, Bio-Rad, CA, EUA). A seguir, as proteínas foram eletricamente transferidas para a membrana de nitrocelulose (bio-Rad, CA, EUA) a $100 \mathrm{~V}$ por 1 hora e 30 minutos. A eficácia da transferência foi verificada pela coloração vermelho de Ponceau. As membranas foram incubadas em tampão Tris salina $(7 \%)$ por 1 hora para reduzir a ligação inespecífica dos anticorpos às proteínas na membrana. Após o bloqueio, as membranas foram incubadas com o anticorpo primário por 12 horas a $4^{\circ} \mathrm{C}$. Os anticorpos que foram utilizados para a realização do experimento estão especificados na tabela 3. As membranas foram reveladas pela exposição das membranas a solução de quimioluminescência (ECL) e captados pelo sistema de foto documentação da BIORAD (chemiDoc ${ }^{\text {TM }}$ XRS+). 
Depois de reveladas, as bandas foram submetidas à análise de densitometria ótica. Os resultados foram normalizados pela expressão de $\beta$-actina.

Tabela 4. Anticorpos primários e secundários utilizados no protocolo de Western Blotting

\begin{tabular}{cccc}
\hline $\begin{array}{c}\text { Anticorpo } \\
\text { primário }\end{array}$ & Empresa/Código & Diluição & $\begin{array}{c}\text { Anticorpo } \\
\text { secundário }\end{array}$ \\
\hline $\begin{array}{c}\text { gp91phox } \\
(\mathbf{c}-15)\end{array}$ & Santa Cruz Biotechnology (sc-5827) & $1: 250$ & Goat 1:500 \\
SOD2 & Santa Cruz Biotechnology (sc-30080) & $1: 500$ & Goat 1:500 \\
& & & \\
$\beta$ & Santa Cruz Biotechnology (sc-47778) & $1: 5000$ & Mouse $1: 5000$ \\
& & & \\
\hline bJackson ImmunoResearch cod.115-035-003 & &
\end{tabular}

\subsection{Quantificação de corticosterona}

A determinação da concentração de corticosterona no plasma foi realizada no laboratório de Neuroendocrinologia do Departamento de Fisiologia da Faculdade de Medicina de Ribeirão Preto - Universidade de São Paulo, sob a orientação do Professor Dr. José Antunes Rodrigues, utilizando a técnica de radioimunoensaio, de acordo com o método descrito por Elias e colaboradores (1997 e 2004). Foram utilizados anticorpos anti-corticosterona (Sigma), preparados em coelhos, com o hormônio conjugado com albumina bovina. A corticosterona [1,2-3(H)] (New England Nuclear) foi utilizada como hormônio marcado. Na separação da fração livre ligada, foi utilizada uma solução de carvão-dextran 0,5/0,5\% (ELIAS et al., 1997, 2004).

\subsection{Ensaio Imunoenzimático (ELISA)}

\subsubsection{Níveis séricos de TGF- $\beta$, IL-2, IL-12, IL-17 e TNF- $\alpha$}

Para a quantificação de citocinas, foi utilizado o kit da empresa Invitrogen e R\&D systems, seguindo-se as especificações do fabricante. Foram utilizadas placas de 96 poços já sensibilizadas com o anticorpo de captura anti citocinas pra ratos.

Foram preparadas as amostras, utilizando-se soro de rato diluído 1:4 (125 $\mu \mathrm{L}$ de soro $+375 \mu \mathrm{L}$ de reagente diluente), e os tubos da curva, através da reconstituição do padrão de $\mathrm{IL}-2(8000$ pg/mL). Para a realização da curva padrão, 
pipetou-se $125 \mu \mathrm{L}$ de reagente diluente em seis tubos de ensaio. No tubo 1, adicionou-se $125 \mu \mathrm{L}$ do padrão diluído inicialmente, e procedeu-se uma série de diluições 1:1 até o tubo 6 , sendo adicionado no tubo 7 apenas o reagente diluente (0 $\mathrm{pg} / \mathrm{mL})$.

Foram adicionados $50 \mu \mathrm{L}$ das amostras experimentais nos demais poços (em duplicata). Em seguida, adicionaram-se às placas $100 \mu \mathrm{L}$ do anticorpo biotinilado anti TNF- $\alpha$, anti TGF- $\beta$, anti IL-2, anti IL-12 e anti IL-17, e as mesmas foram incubadas por 2 horas em temperatura ambiente. Após a incubação as placas foram lavadas quatro vezes com 400 $\mu \mathrm{L} /$ poço de tampão de lavagem (25 vezes concentrado, diluído 1:25 em água destilada).

A revelação enzimática foi feita pela adição de $100 \mu \mathrm{L} /$ poço de estreptavidina-peroxidase (HPR) diluída em tampão de diluição (120 $\mu \mathrm{L}$ de HPR diluído em $12 \mathrm{~mL}$ tampão de diluição), e as placas foram incubadas por 30 min à temperatura ambiente. Após novo ciclo de quatro lavagens, foi adicionado substrato cromógeno $100 \mu \mathrm{L} /$ poço, incubando novamente por $30 \mathrm{~min}$, protegendo da luz e parando a reação com a adição de $100 \mu \mathrm{L}$ de solução de parada $\left(\mathrm{H}_{3} \mathrm{PO}_{4} 1 \mathrm{M}\right)$.

As densidades ópticas (D.O.) das placas foram lidas em leitor de microplacas (Teccan, Modelo Sunrise- $\mu$ Quant) em um comprimento de onda de 450nm. 
ANÁLISE ESTATÍSTICA 


\section{ANÁLISE ESTATÍSTICA}

Os dados dos experimentos foram analisados estatisticamente pelo programa computacional GraphPad Prism versão 5.0. A comparação entre os grupos foi realizada através de análise de variância: One-Way ANOVA. As comparações posthoc foram realizadas com 0 teste de Bonferroni. Foram considerados estatisticamente significativos os resultados com $p<0,05$. 
RESULTADOS 


\section{RESULTADOS}

\subsection{Caracterização fenotípica e funcional de macrófagos peritoneais}

A análise do percentual da ativação de macrófagos e células apresentadoras de antígenos, obtidos a partir do lavado peritoneal, através da análise da expressão de receptores $\mathrm{MHC}$ Classe II-RT1B. macrófagos, foi determinada através da técnica de citometria de fluxo. Foi evidenciado uma diminuição estatisticamente significativa tanto na população de macrófagos peritoneais (figura 1A), quanto na expressão de RT1B (figura 1B), em animais infectados e senis, comparados aos jovens e infectados. Além disso, podemos observar um aumento significativo na expressão de RT1B nos animais jovens infectados, 9 e 16 dias após a infecção, quando comparados aos animais jovens não infectados e ao grupo senil controle e infectado, demonstrando que o aumento da expressão de marcadores de superfície MHC II ocorreu durante a infecção por $T$. cruzi apenas no grupo jovem infectado. 
Figura 1: Porcentagem da população de macrófagos $(A)$ e macrófagos ativados via $\mathrm{MHC}$-II (molécula $\mathrm{RT}_{1 \mathrm{~B}}^{+}$) (B), no lavado peritoneal de ratos Wistar machos jovens e senis não infectados e infectados com $1 \times 10^{5}$ formas tripomastigotas sanguícolas da cepa $Y$ de Trypanosoma cruzi, no $16^{\circ}$ dia após a infecção nos seguintes grupos: Jovem Controle (JC), Senil Controle (SC), Jovem Infectado (JI) e Senil Infectado (SI). One-way ANOVA seguido do pós-teste de Bonferroni, com ${ }^{*} p<0,05,{ }^{* *} p<0,01 e^{* * *} p<0,001$. Todos os dados expressam a média \pm SEM. $n=5$ animais por grupo.

\section{(A)População de macrófagos}

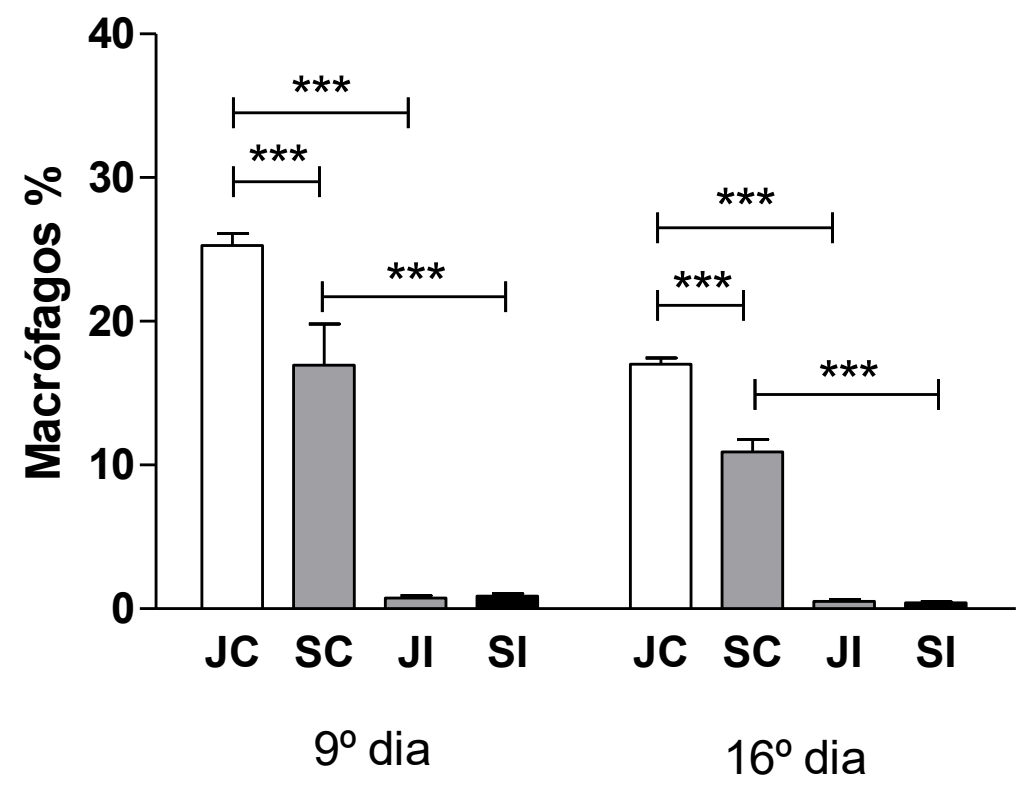

(B) Macrófagos ativados

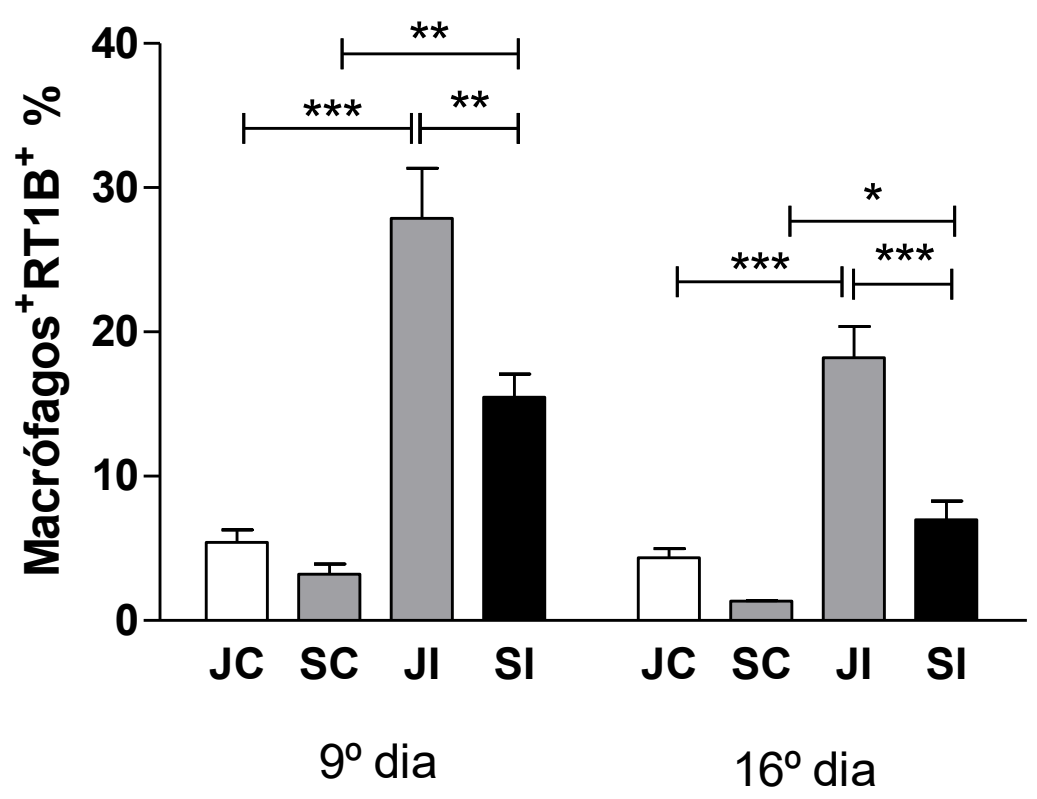




\subsection{Análise fenotípica e funcional de células dendríticas}

Não foram observadas diferenças estatisticamente significantes nas porcentagens de células dendríticas, obtidas a partir do lavado peritoneal (figura 2A) e baço (figura 2B), entre os grupos em estudo.

A análise da expressão de moléculas coestimulatórias CD80 (B7.1) e CD86 (B7.2) em células APC foi realizada através da marcação realizada em citometria de fluxo, utilizando-se anticorpos monoclonais para as moléculas CD80 e CD86. Ao avaliarmos o percentual de células APC que expressavam CD80, observamos um aumento significativo destas células nos animais jovens e senis infectados, quando comprado aos animais jovens e senis controle, respectivamente (figura $3 \mathrm{~A}$ ).

Com relação à expressão da molécula coestimulatória CD86, não foram observadas diferenças significativas na expressão de CD86 em células APC entre os animais dos grupos em estudo (figura 3B). 
Figura 2: Caracterização fenotípica de células dendríticas, obtidas a partir do lavado peritoneal $(A)$ e Baço $(B)$ em ratos Wistar machos não infectados e infectados com $1 \times 10^{5}$ formas tripomastigotas sanguícolas da cepa $Y$ de Trypanosoma cruzi, no $9^{\circ}$ e $16^{\circ}$ dia após a infecção nos seguintes grupos: Jovem Controle (JC), Senil Controle (SC), Jovem Infectado (JI) e Senil Infectado (SI). One-way ANOVA seguido do pós-teste de Bonferroni. Todos os dados expressam a média \pm SEM. $n=5$ animais por grupo.

(A) Células dendríticas - lavado peritoneal

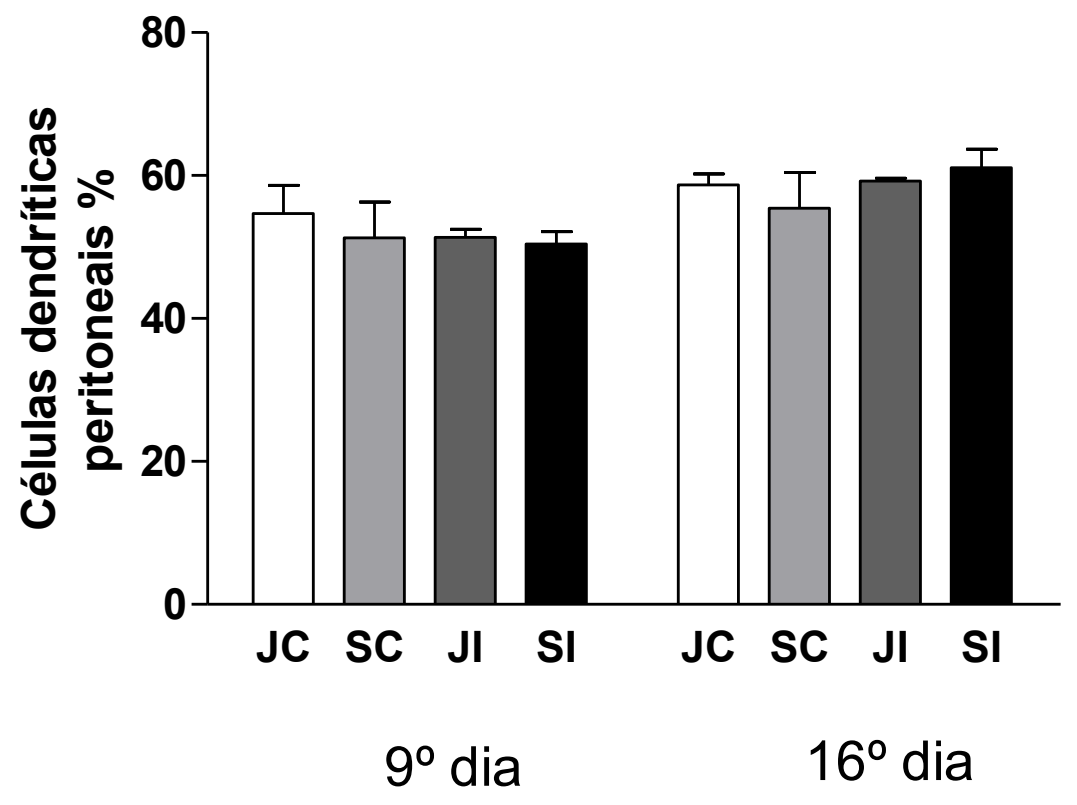

(B) Células dendríticas - Baço

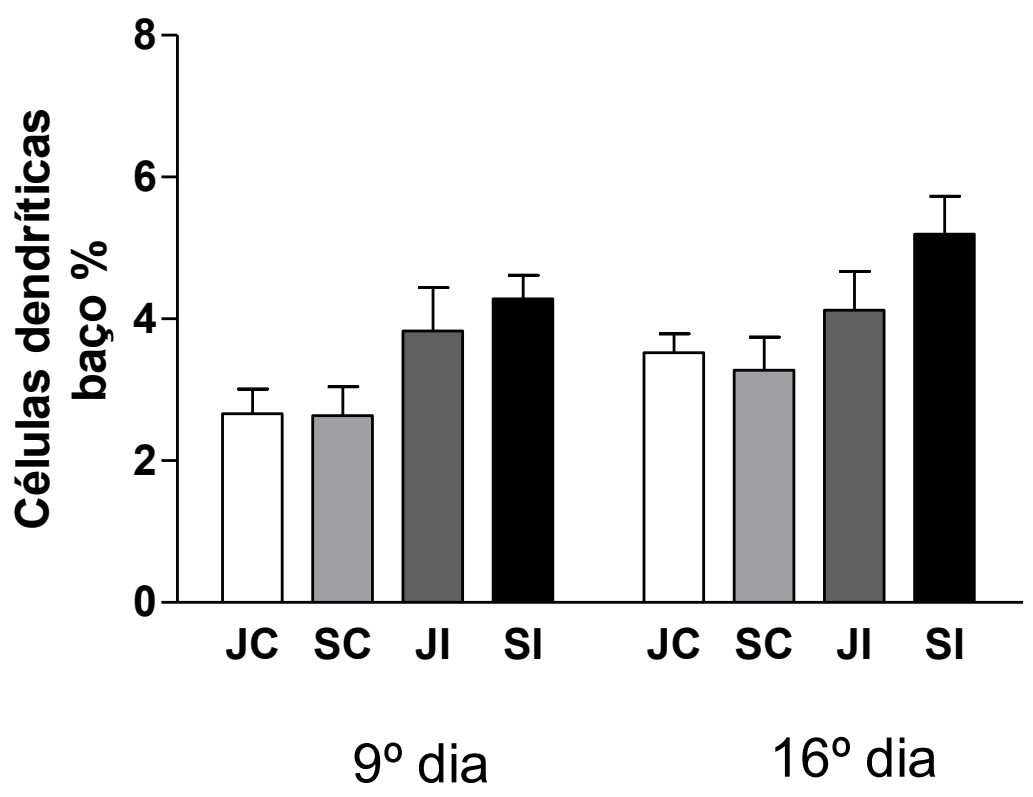


Figura 3: Porcentagem das moléculas CD80 (A) e CD86 (B) em células apresentadoras de antígenos (APC), obtidas a partir do lavado peritoneal de ratos Wistar machos não infectados e infectados com $1 \times 10^{5}$ formas tripomastigotas sanguícolas da cepa $Y$ de Trypanosoma cruzi, no $9^{\circ}$ e $16^{\circ}$ dia após a infecção nos seguintes grupos: Jovem Controle (JC), Senil Controle (SC), Jovem Infectado (JI) e Senil Infectado (SI). One-way ANOVA seguido do pós-teste de Bonferroni, com ${ }^{* *} p<0,01 e^{* * *} p<0,001$. Todos os dados expressam a média \pm SEM. $\mathrm{n}=5$ animais por grupo.

(A) Molécula coestimulatória CD80 (B7.1)

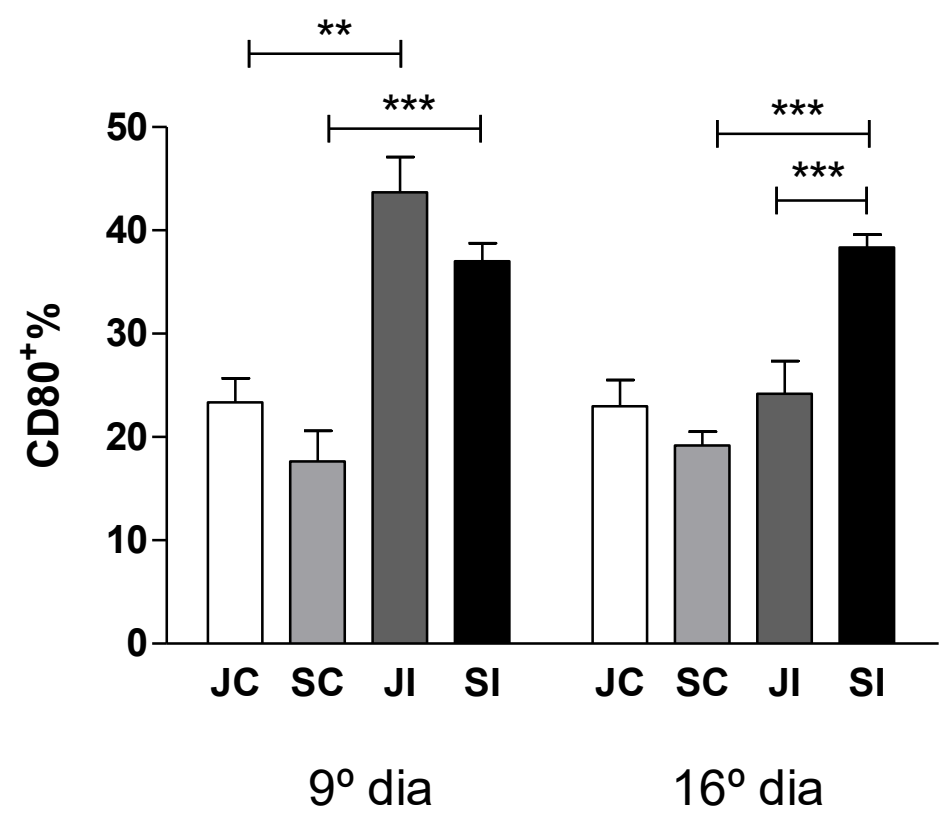

(B)Molécula coestimulatória CD86 (B7.2)

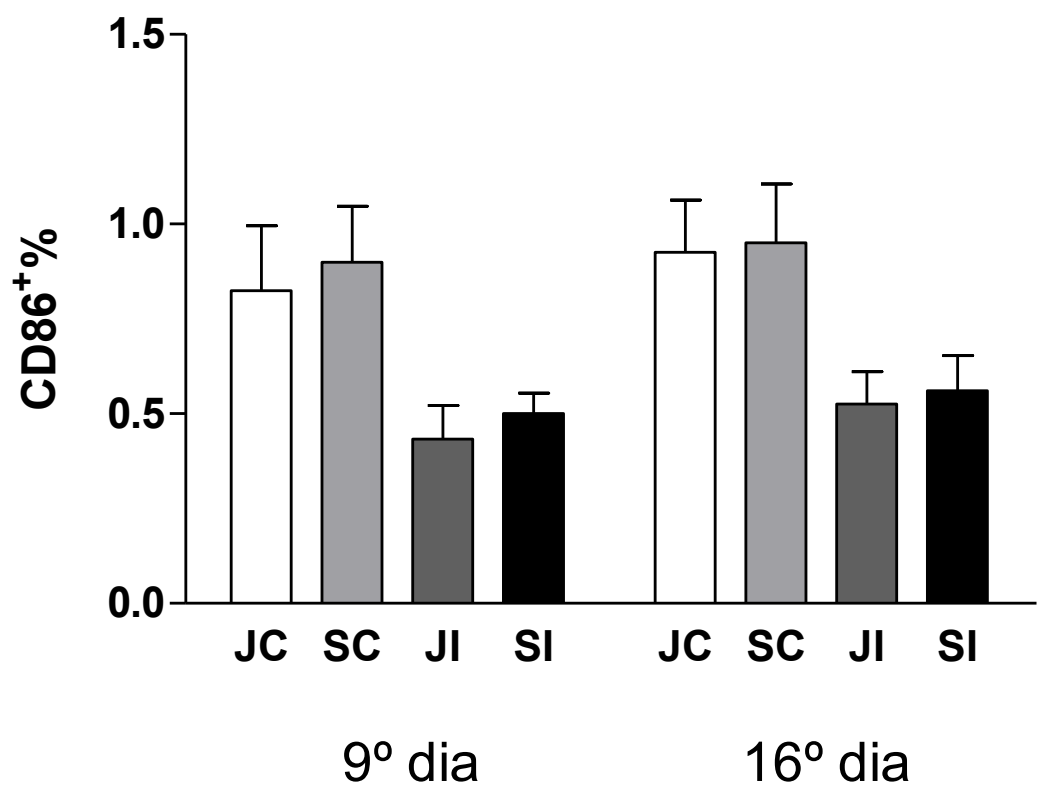


6.3. Avaliação do percentual de células NK $\left(C D 161^{+}\right)$e NKT $\left(C D 3^{+} C D 161^{+}\right)$em células esplênicas

A figura 4A representa a avaliação do percentual de células NK $\left(C D 161^{+}\right)$, enquanto a figura 4B mostra a análise das populações de células esplênicas NKT $\left(C D 3^{+} C D 161^{+}\right)$. No $9^{\circ}$ dia após a infecção por $T$. cruzi não houve diferença significativa no percentual de células NK. Entretanto, na figura 4B observamos que o percentual de células NKT diminuiu significativamente nos animais do grupo senil, tanto controle quanto infectado, quando comparados aos animais do grupo jovem. 
Figura 4: Análise da porcentagem das populações de células NK $(A)$ e NKT (B) no baço de ratos Wistar machos jovens e senis não infectados e infectados com $1 \times 10^{5}$ formas tripomastigotas sanguícolas da cepa $Y$ de Trypanosoma cruzi, no $9^{\circ}$ e $16^{\circ}$ dia após a infecção nos seguintes grupos: Jovem Controle (JC), Senil Controle (SC), Jovem Infectado (JI) e Senil Infectado (SI). One-way ANOVA seguido do pós-teste de Bonferroni, com ${ }^{* *} p<0,01 e^{* * *} p<0,001$. Todos os dados expressam a média \pm SEM. $n=5$ animais por grupo.

(A)Células Natural Killer

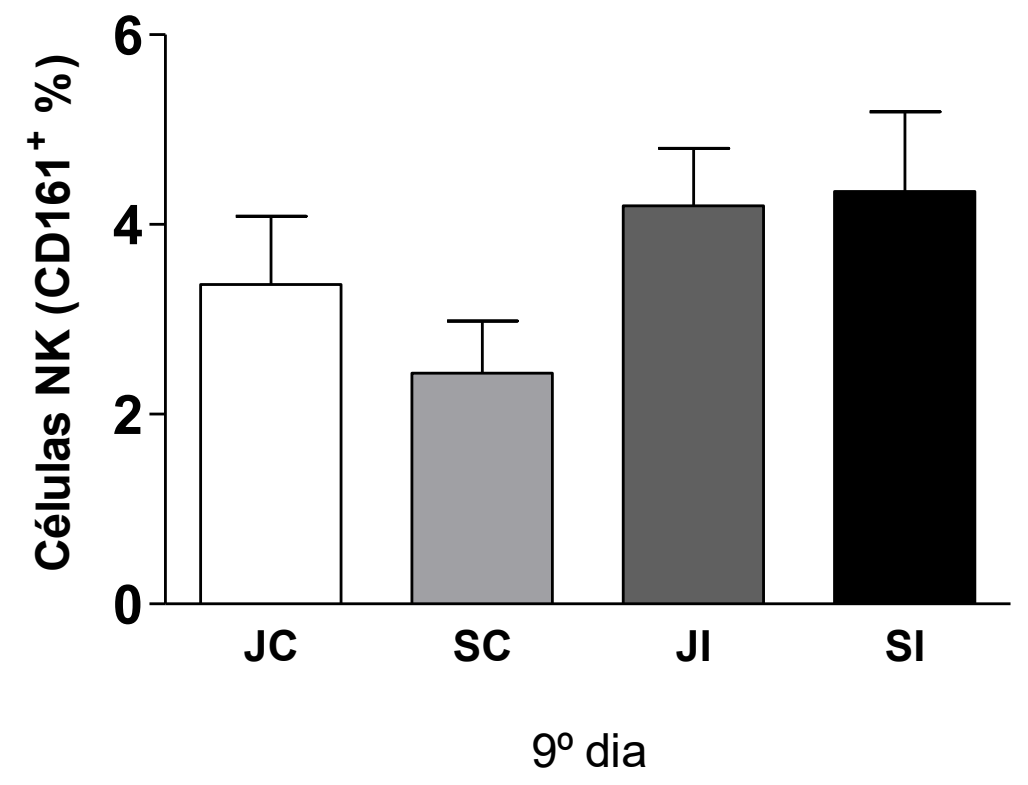

(B)Células Natural Killer T

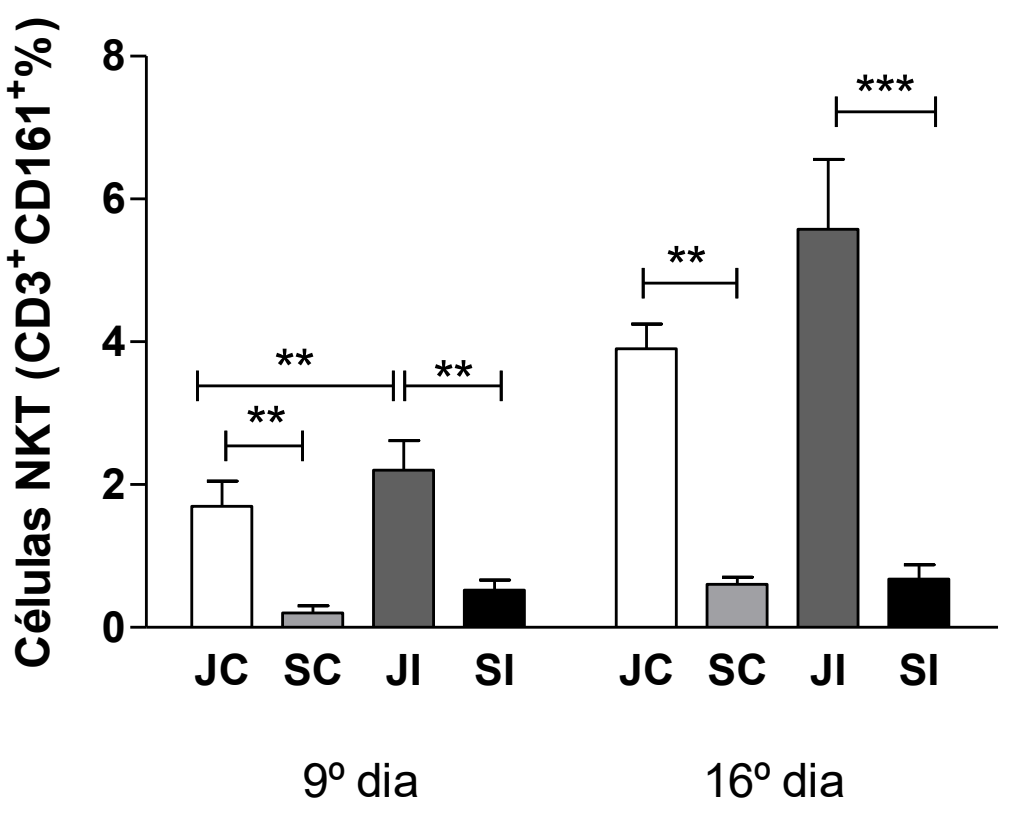




\subsection{Análise das subpopulações de linfócitos $\mathrm{T} \mathrm{CD4}^{+}$e $\mathrm{T} \mathrm{CD}^{+}$em células esplênicas}

A figura 5 representa uma análise comparativa das subpopulações de linfócitos $\mathrm{T} \mathrm{CD}^{+} \mathrm{CD}^{+}$(figura $5 \mathrm{~A}$ ) e linfócitos $\mathrm{T} \mathrm{CD} 3^{+} \mathrm{CD} 8^{+}$nas células esplênicas (figura 5B). Como podemos observar, na figura 5A, 9 dias após a infecção por $T$. cruzi, o percentual de células T $\mathrm{CD}^{+}$aumentou significativamente nos animais do grupo jovem infectado quando comparado aos animais jovens controle $\left({ }^{*} p<0,05\right)$. Além disso, observa-se uma redução no percentual de células T CD4 ${ }^{+}$nos animais senis, tanto controle quanto infectado, quando comparados aos animais jovens.

Adicionalmente, na figura 5B, podemos observar um aumento significativo no percentual de células $\mathrm{T} \mathrm{CD8}^{+}$nos animais do grupo senil infectado, quando comparado aos animais do grupo senil controle. 
Figura 5: Porcentagem das subpopulações de linfócitos $T C D 3^{+} C D 4^{+}(A)$ e $T$ CD3 ${ }^{+} C D 8^{+}(B)$ no baço de ratos Wistar machos jovens e senis não infectados e infectados com $1 \times 10^{5}$ formas tripomastigotas sanguícolas da cepa $Y$ de Trypanosoma cruzi, no $9^{\circ}$ e $16^{\circ}$ dia após a infecção nos seguintes grupos: Jovem Controle (JC), Senil Controle (SC), Jovem Infectado (JI) e Senil Infectado (SI). One-way ANOVA seguido do pós-teste de Bonferroni, com ${ }^{*} p<0,05,{ }^{* *} p<0,01 e^{* * *} p<0,001$. Todos os dados expressam a média \pm SEM. $n=5$ animais por grupo.

(A) Linfócitos T CD4 ${ }^{+}$

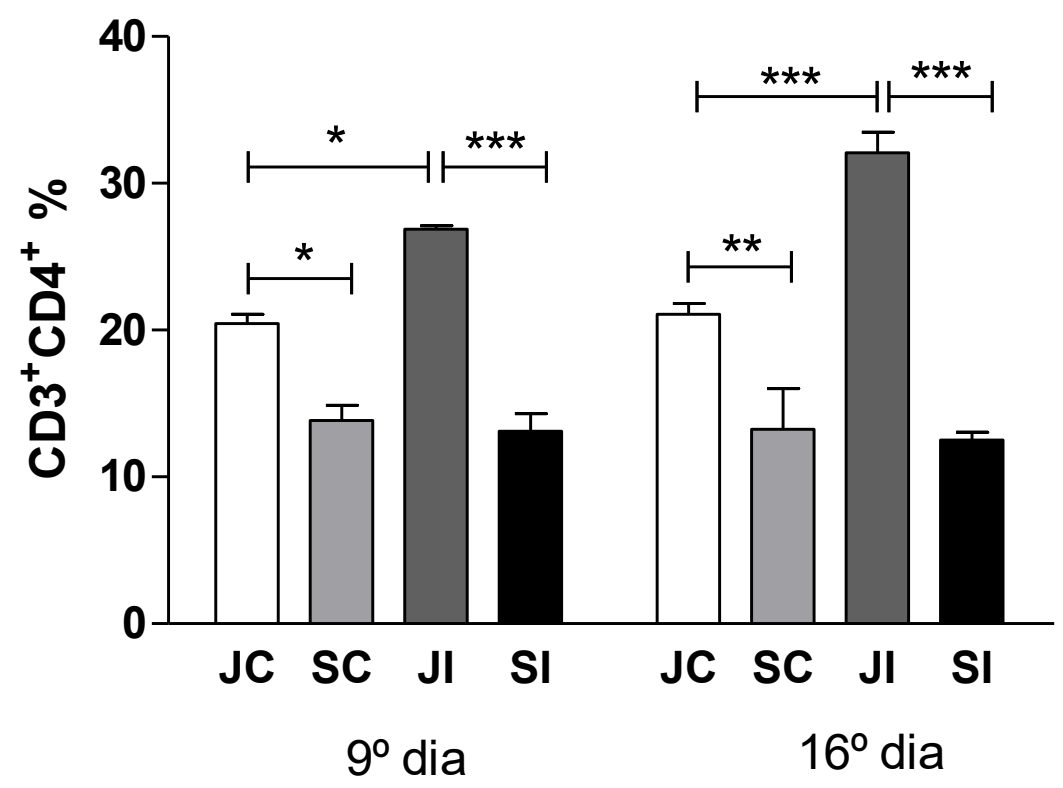

(B) Linfócitos T CD8 ${ }^{+}$

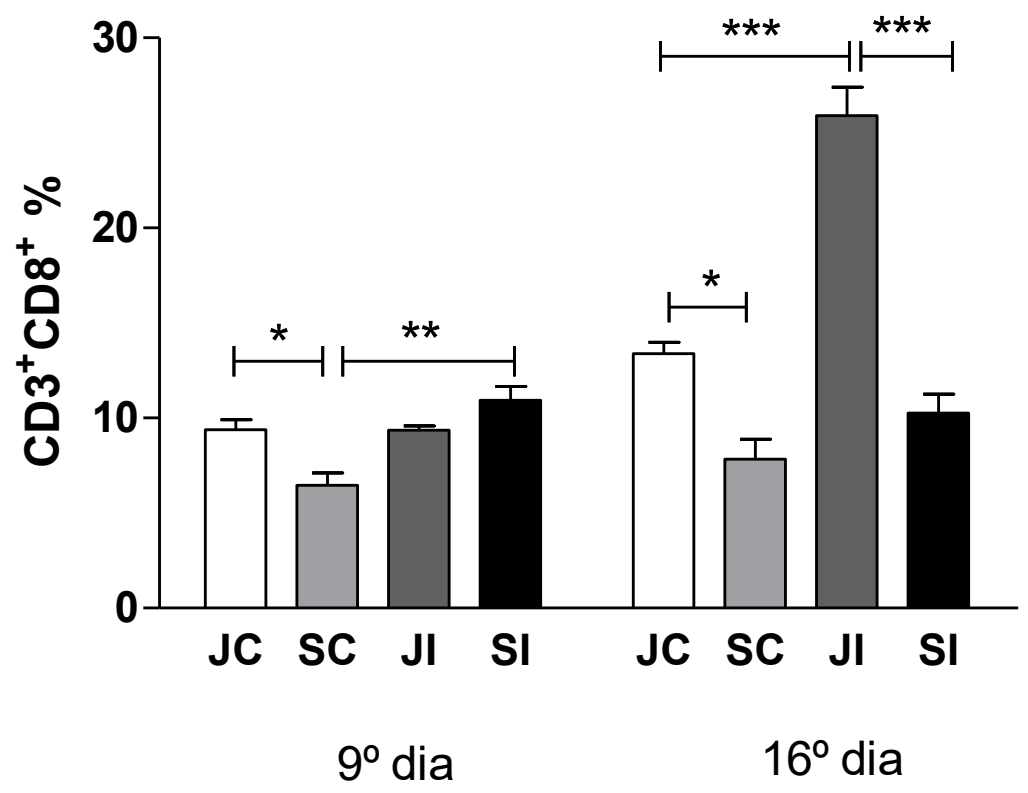


6.5. Análise da expressão de CD28 nas subpopulações de linfócitos T CD4 ${ }^{+}$e CD8 $^{+}$

Como podemos observar na figura 6 (A e C), a senescência por si provocou o acúmulo de linfócitos T CD4 ${ }^{+} \mathrm{CD} 28^{-}$e $\mathrm{T}$ CD3 ${ }^{+} \mathrm{CD} 28^{-}$nos animais senis quando comparados aos animais pertencentes ao grupo jovens (não infectados). Por outro lado, não foram observadas alterações significativas no percentual de linfócitos $T$ $\mathrm{CD}^{+}{ }^{\mathrm{CD}} 28^{-}$(figura $6 \mathrm{~B}$ ).

Na figura 7 ( $A$ e $B$ ), observamos que a senescência por si provocou uma diminuição de linfócitos T CD4 ${ }^{+} \mathrm{CD} 28^{+}$(figura 7A) e T CD8 ${ }^{+} \mathrm{CD} 28^{+}$(figura 7B) nos animais senis, quando comparado aos animais pertencentes ao grupo jovens, em ambos os dias experimentais da infecção por T. cruzi. 
Figura 6: Percentual de linfócitos $\mathrm{T} \mathrm{CD4}^{+} \mathrm{CD} 28^{-}(\mathrm{A}), \mathrm{T}^{-} \mathrm{CD} 8^{+} \mathrm{CD} 28^{-}(\mathrm{B})$ e $\mathrm{T} \mathrm{CD}^{+} \mathrm{CD}^{-} 8^{-}(\mathrm{C})$ em células esplênicas de ratos Wistar machos não infectados e infectados com $1 \times 10^{5}$ formas tripomastigotas sanguícolas da cepa $Y$ de Trypanosoma cruzi, no $9^{\circ}$ e $16^{\circ}$ dia após a infecção nos seguintes grupos: Jovem Controle (JC), Senil Controle (SC), Jovem Infectado (JI) e Senil Infectado (SI). One-way ANOVA seguido do pós-teste de Bonferroni, com ${ }^{* *} p<0,01 e^{* * *} p<0,001$. Todos os dados expressam a média \pm SEM. $n=5$ animais por grupo.

(A) Linfócitos T CD4 ${ }^{+} \mathrm{CD28}-$

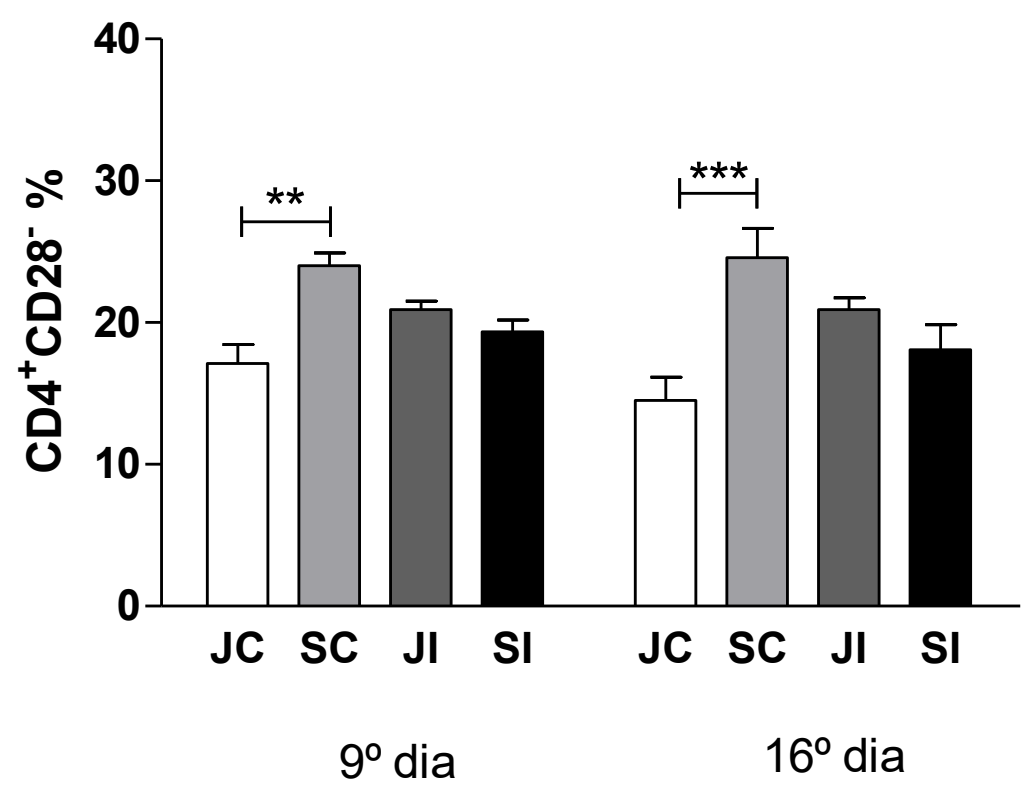

(B) Linfócitos T CD8 ${ }^{+}$CD28-

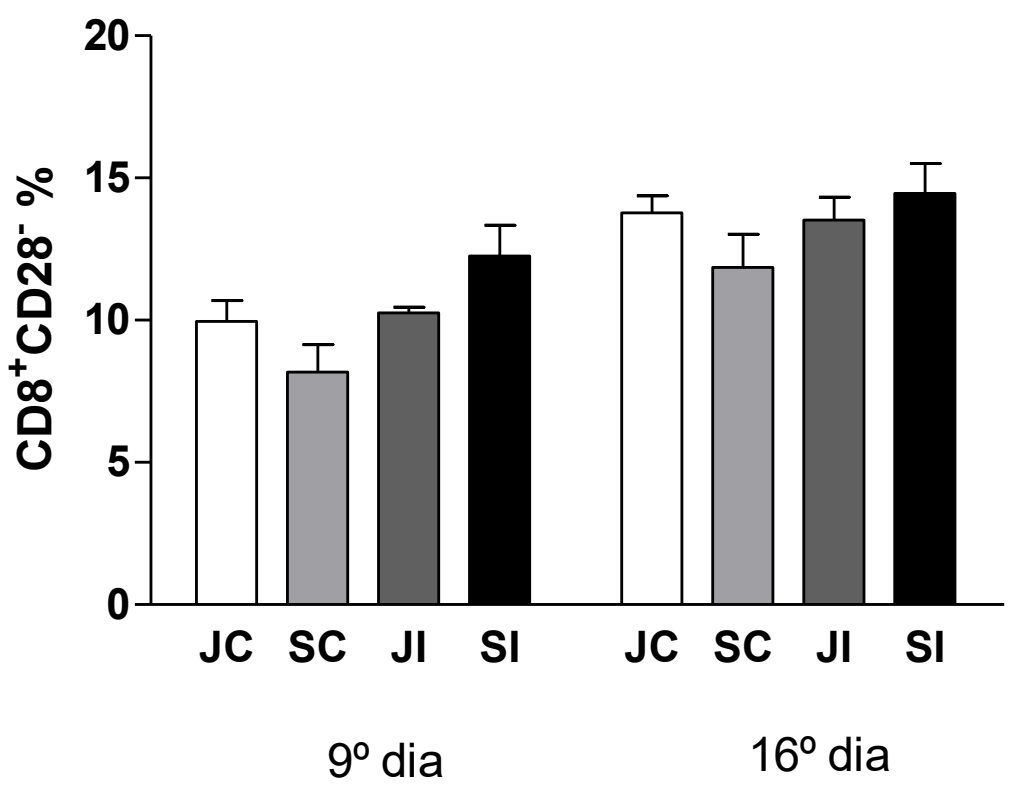


(C) Linfócitos $\mathrm{T} \mathrm{CD3}^{+} \mathrm{CD} 28^{-}$

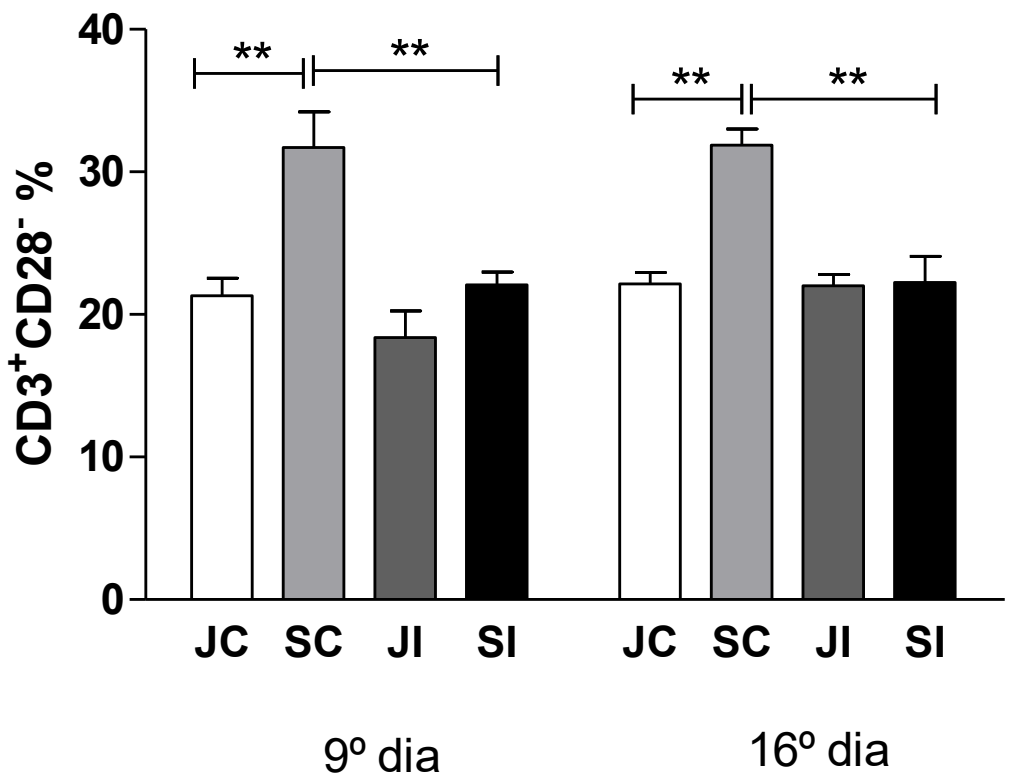


Figura 7: Porcentagem da expressão da molécula coestimulatória das subpopulações de linfócitos $\mathrm{T} \mathrm{CD}^{+}(\mathrm{A})$ e linfócitos $\mathrm{T} \mathrm{CD}^{+}(\mathrm{B})$ no baço de ratos Wistar machos jovens e senis não infectados e infectados com $1 \times 10^{5}$ formas tripomastigotas sanguícolas da cepa $\mathrm{Y}$ de Trypanosoma cruzi, no $9^{\circ}$ e $16^{\circ}$ dia após a infecção nos seguintes grupos: Jovem Controle (JC), Senil Controle (SC), Jovem Infectado (JI) e Senil Infectado (SI). One-way ANOVA seguido do pós-teste de Bonferroni, com ${ }^{*} p<0,05,{ }^{* *} p<0,01 e^{* * *} p<0,001$. Todos os dados expressam a média \pm SEM. $\mathrm{n}=5$ animais por grupo.

\section{(A) Linfócitos T CD4 ${ }^{+} \mathrm{CD} 28^{+}$}

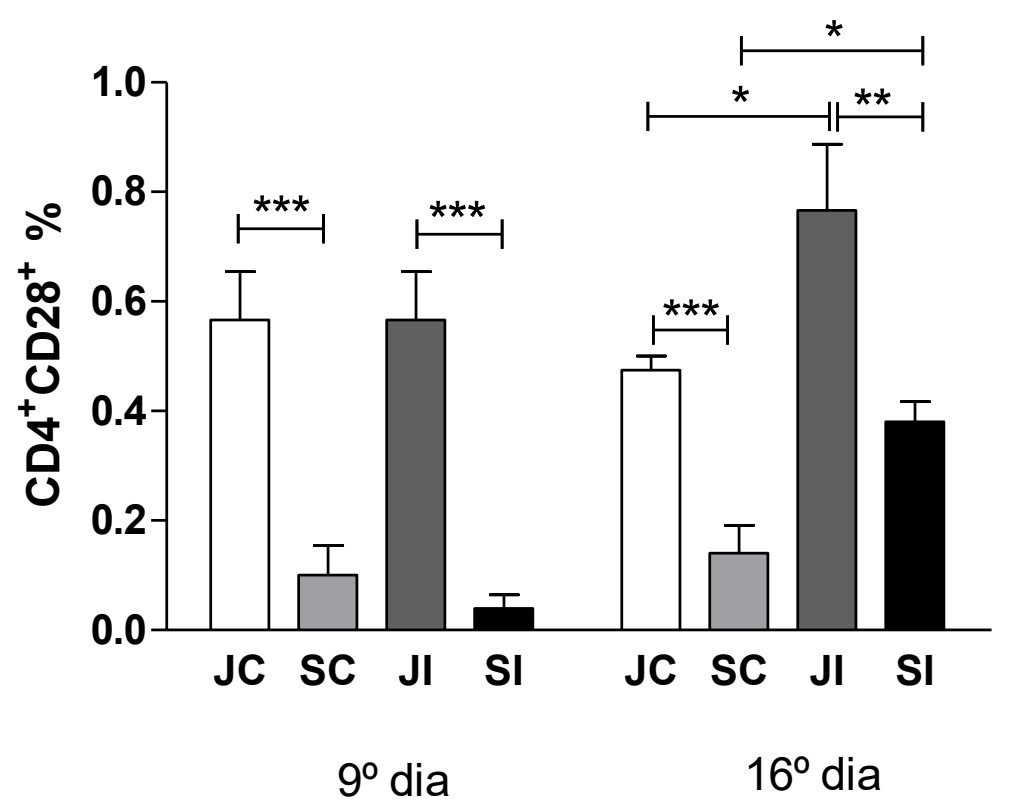

(B) Linfócitos T CD8 ${ }^{+} \mathrm{CD} 28^{+}$

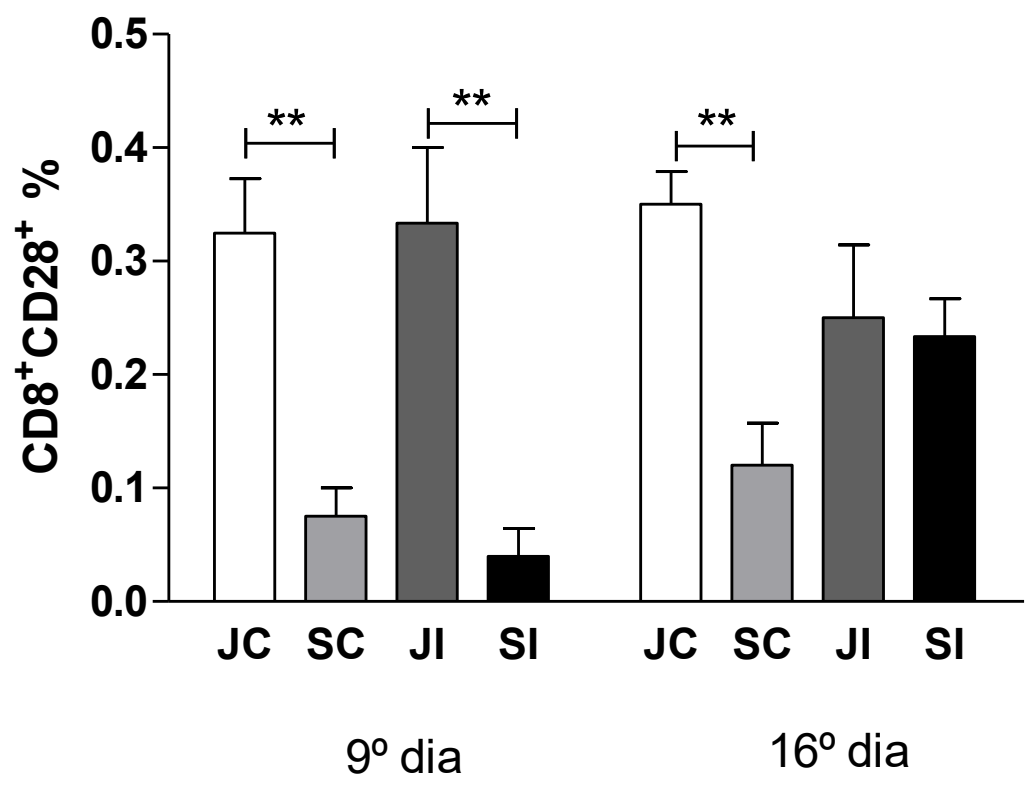


6.6. Avaliação do percentual de linfócitos $B\left(C D 45 R A^{+}\right)$em células esplênicas

A figura 8 representa a avaliação do percentual de linfócitos $B$, através da expressão da molécula CD45RA ${ }^{+}$, em células do baço. Como podemos observar, 9 dias após a infecção por T. cruzi, observou-se uma redução no percentual de células B nos animais do grupo senil, tanto controle quanto infectado, quando comparados aos animais do grupo jovem. 
Figura 8: Porcentagem da população de linfócitos $B$ no baço de ratos Wistar machos jovens e senis não infectados e infectados com $1 \times 10^{5}$ formas tripomastigotas sanguícolas da cepa Y de Trypanosoma cruzi, no $16^{\circ}$ dia após a infecção nos seguintes grupos: Jovem Controle (JC), Senil Controle (SC), Jovem Infectado (JI) e Senil Infectado (SI). One-way ANOVA seguido do pós-teste de Bonferroni, com ${ }^{* *} p<0,001$. Todos os dados expressam a média \pm SEM. $\mathrm{n}=5$ animais por grupo.

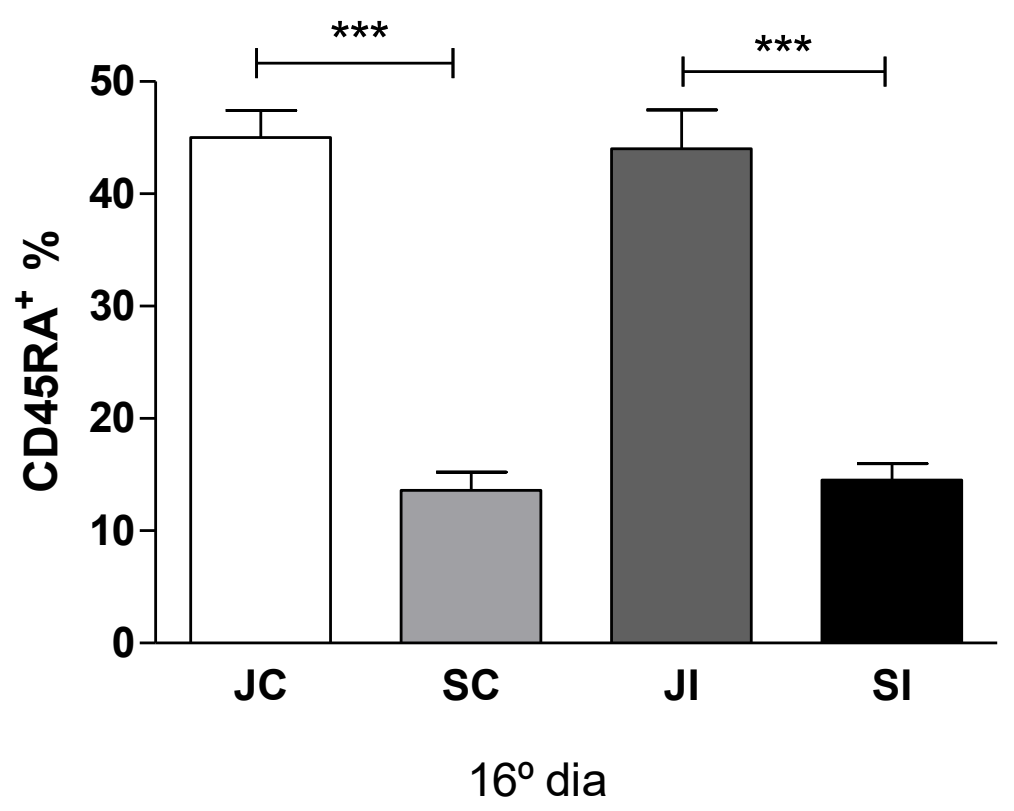




\subsection{Caracterização de células $T$ reguladoras}

Com o objetivo de avaliar a participação das células $\mathrm{T}$ reguladoras durante a infecção experimental por $T$. cruzi, a expressão de FOXP3 ${ }^{+}$foi analisada em células $\mathrm{T} C D 4^{+} \mathrm{CD} 25^{\text {high }}$ e $\mathrm{CD} 4^{+} \mathrm{CD} 25^{\text {low }}$ do baço de ratos Wistar, através da técnica de citometria de fluxo.

Não foi observada diferença significativa na população de células $T$ CD4 ${ }^{+}$CD25- (figura 9A) nos animais jovens e senis, infectados ou não. Por outro lado, observamos um aumento no percentual de linfócitos $C D 4^{+} C D 25^{\text {high }}$ nos animais do grupo jovem infectado, quando comparado aos animais dos grupos jovem controle e senil infectado (figura 9B).

A expressão da molécula CD25 na superfície de células T não é suficiente para determinar o perfil fenotípico das células Treg, uma vez que esta molécula está presente também em células ativadas (BAECHER-ALLAN et al., 2001). Portanto, para determinarmos se o aumento na população de linfócitos TCD4 ${ }^{+} C D 25^{\text {high }}$, foi decorrente do aumento na população de células Treg, e não da ativação de linfócitos $\mathrm{T}$ naive, avaliamos a expressão de FOXP3, fator de transcrição característico de células Treg nos linfócitos T CD4 ${ }^{+}$CD25 $5^{\text {high }}$.

A análise dos dados demonstrou que o envelhecimento foi associado a um aumento no percentual de linfócitos $\mathrm{CD}^{+}{ }^{+} \mathrm{CD} 25^{\text {lowFOXP3 }}{ }^{+}$(figura $10 \mathrm{~A}$ ), observado nos animais senis quando comparados aos animais pertencentes ao grupo jovem, sem infecção. Por outro lado, os animais senis, não infectados, apresentaram uma acentuada redução no percentual de linfócitos $C D 4^{+} \mathrm{CD} 25^{\text {high }} \mathrm{FOXP} 3^{+}$quando comparados aos animais jovens controles (figura 10B). 
Figura 9: Porcentagem de linfócitos $T \mathrm{CD} 4^{+} \mathrm{CD} 25^{\text {high }}(\mathrm{A})$ e $\mathrm{T} C D 4^{+} \mathrm{CD} 25^{-}(\mathrm{B})$ no baço de ratos Wistar machos não infectados e infectados com $1 \times 10^{5}$ formas tripomastigotas sanguícolas da cepa $Y$ de Trypanosoma cruzi, no $9^{\circ}$ e $16^{\circ}$ dia após a infecção nos seguintes grupos: Jovem Controle (JC), Senil Controle (SC), Jovem Infectado (JI) e Senil Infectado (SI). Oneway ANOVA seguido do pós-teste de Bonferroni, com ${ }^{*} p<0,05$, e ${ }^{* * *} p<0,001$. Todos os dados expressam a média \pm SEM. $n=5$ animais por grupo.

\section{(A) Linfócitos CD4 ${ }^{+}$CD25-}

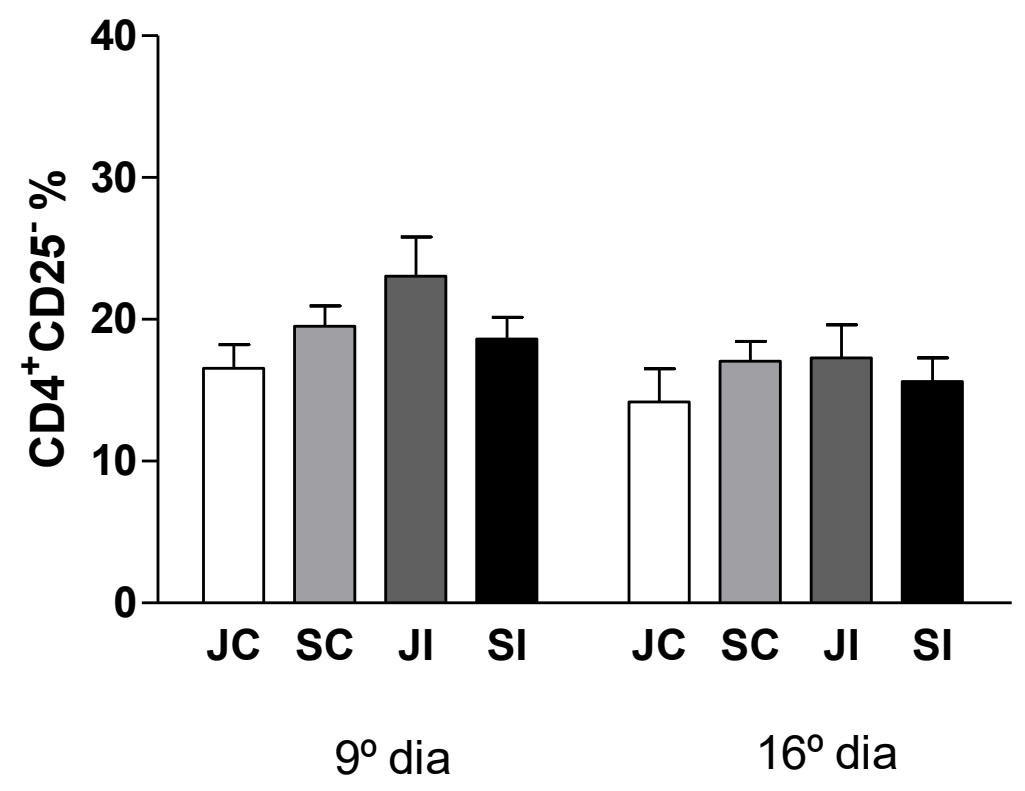

(B) Linfócitos T CD4+CD25 high

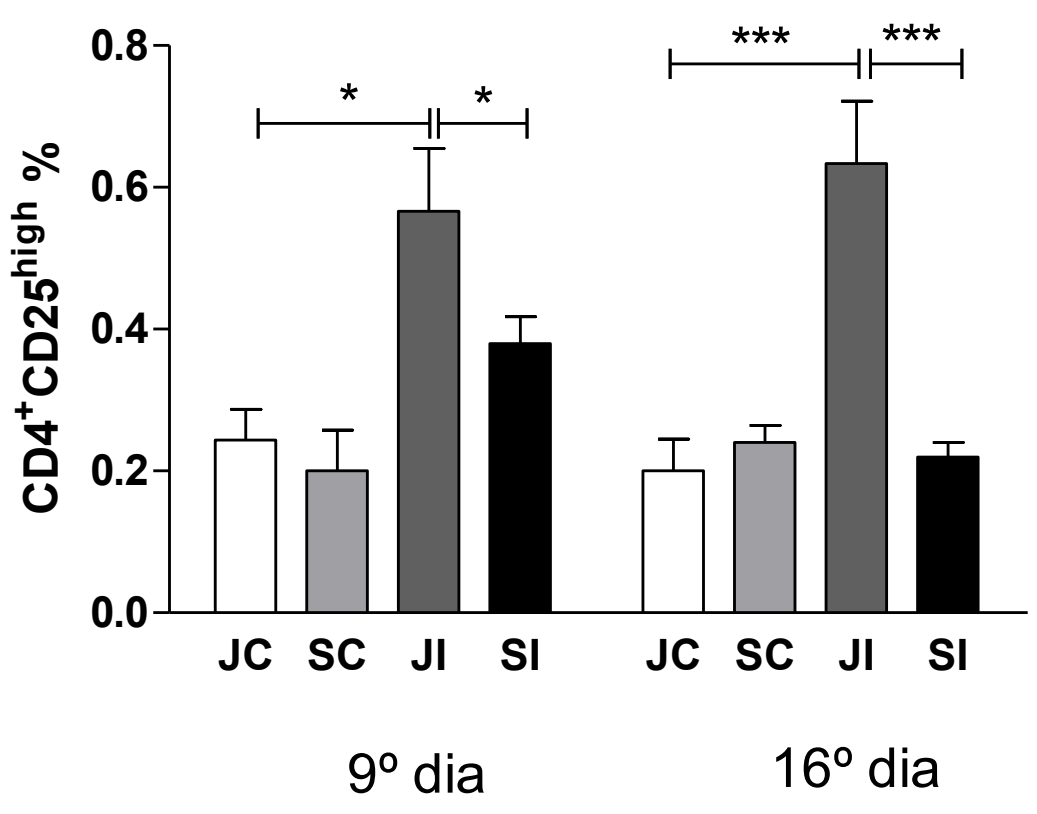


Figura 10: Porcentagem do fator de transcrição FOXP3 em células $C D 4^{+} C D 25^{\text {low }}(A)$ e $\mathrm{CD} 4^{+} \mathrm{CD} 25^{\text {high }}(\mathrm{B})$ no baço de ratos Wistar machos não infectados e infectados com $1 \times 10^{5}$ formas tripomastigotas sanguícolas da cepa $Y$ de Trypanosoma cruzi, no $9^{\circ}$ dia e $16^{\circ}$ dia após a infecção nos seguintes grupos: Jovem Controle (JC), Senil Controle (SC), Jovem Infectado (JI) e Senil Infectado (SI). One-way ANOVA seguido do pós-teste de Bonferroni, com ${ }^{*} p<0,05 e{ }^{* *} p<0,01$. Todos os dados expressam a média \pm SEM. $n=5$ animais por grupo.

(A) Linfócitos T CD4 ${ }^{+}$CD25 $5^{\text {lowFOXP3 }}$

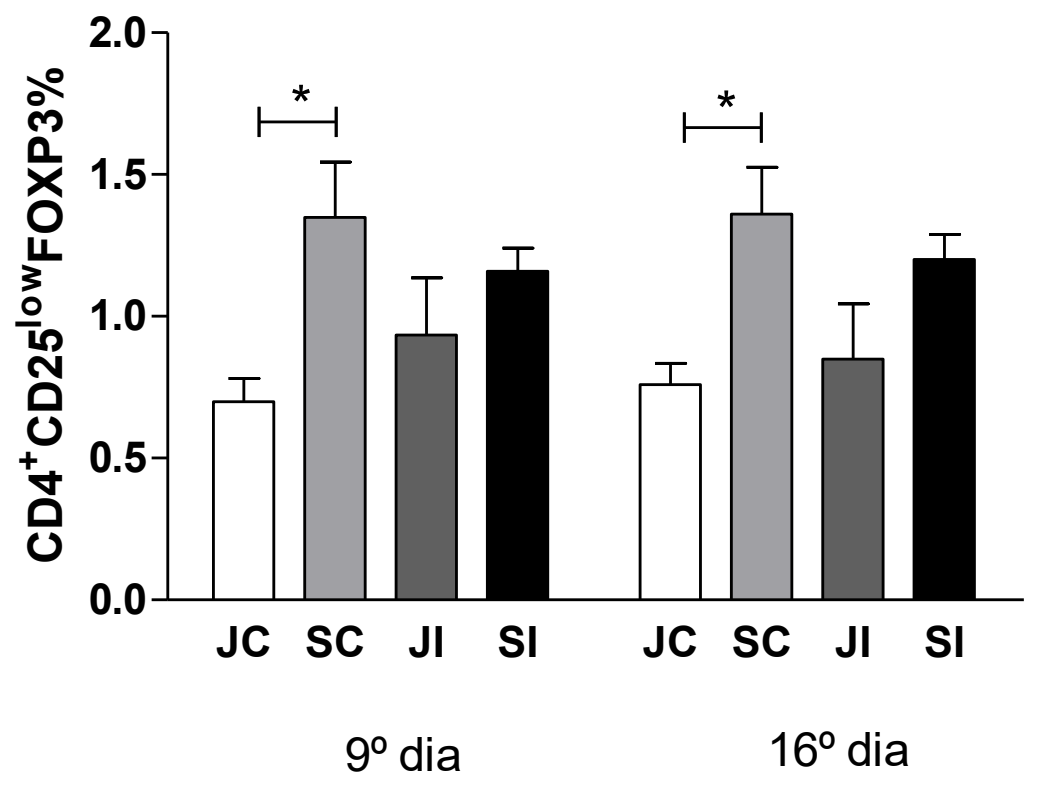

(B)Linfócitos T CD4 ${ }^{+}$CD25 $5^{\text {high } F O X P 3 ~}$

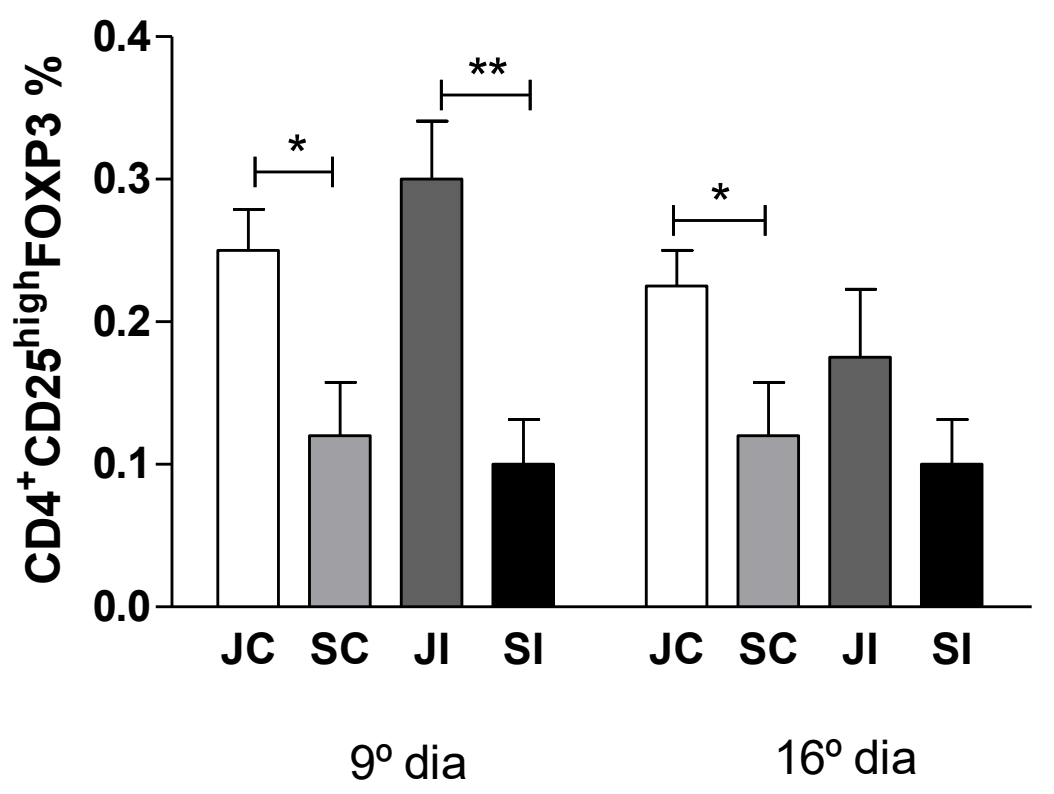




\subsection{Quantificação de Corticosterona}

Com o progressivo envelhecimento foram observadas alterações significativas nos níveis plasmáticos de corticosterona, com um aumento da concentração deste hormônio nos animais senis, quando comparados aos animais jovens não infectados, tanto no $9^{\circ}$ quanto no $16^{\circ}$ dia após a infecção $\left({ }^{* *} p<0,01\right)$. Além disso, podemos observar um aumento na produção de corticosterona em animais jovens infectados, quando comparados aos jovens controle, 9 dias após a infecção $\left({ }^{*} p<0,05\right)$. Entretanto, no $16^{\circ}$ dia de experimento, observou-se que nos animais jovens infectados os níveis deste hormônio se aproximaram dos valores basais, enquanto que os animais senis infectados permaneceram com concentrações elevadas de corticosterona $\left({ }^{*} p<0,05\right)$. 
Figura 11: Concentração de corticosterona em $\mu \mathrm{g} / \mathrm{dL}$ no plasma de ratos Wistar machos jovens e senis não infectados e infectados com $1 \times 10^{5}$ formas tripomastigotas sanguícolas da cepa $Y$ de Trypanosoma cruzi, no $9^{\circ}$ e $16^{\circ}$ dia após a infecção nos seguintes grupos: Jovem Controle (JC), Senil Controle (SC), Jovem Infectado (JI) e Senil Infectado (SI). One-way ANOVA seguido do pós-teste de Bonferroni, com ${ }^{*} p<0,05$ e ${ }^{* *} p<0,01$. Todos os dados expressam a média \pm SEM. $n=5$ animais por grupo.

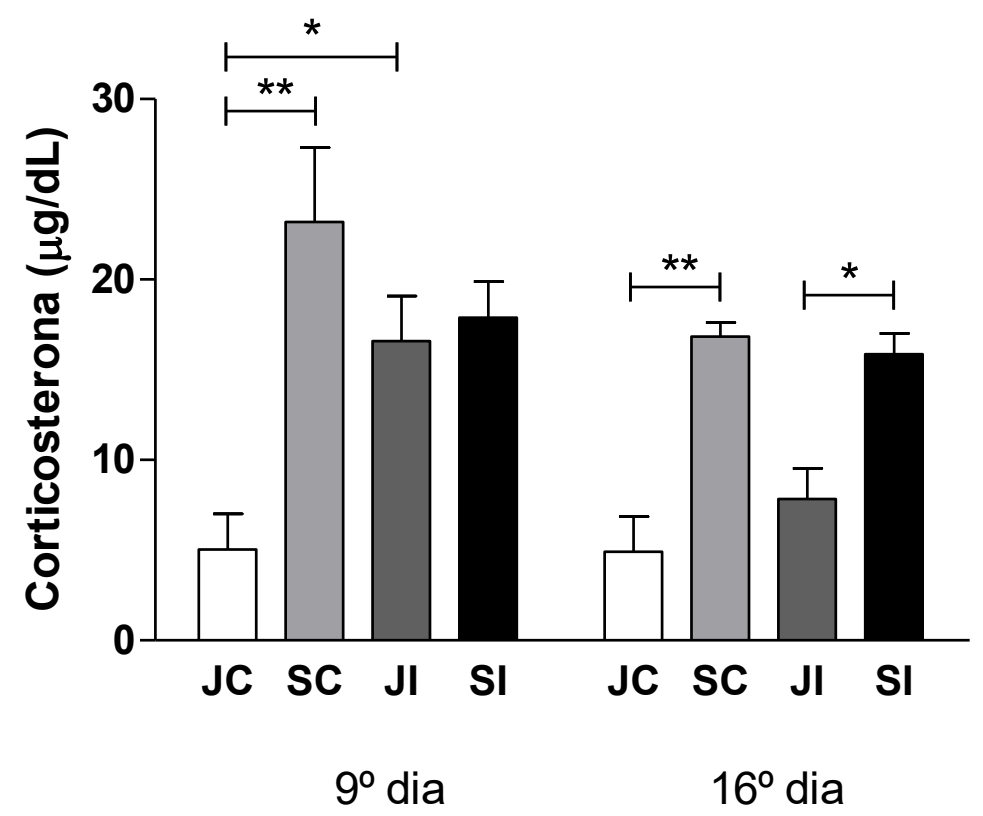




\subsection{Análise do processo de apoptose de esplenócitos}

Em células esplênicas (figura 12A), observamos que a infecção por si ocasionou um aumento no percentual de células em estágio inicial de apoptose, fato evidenciado nos animais jovens infectados quando comparado aos animais sem infecção. Além disso, observamos um aumento significativo no processo apoptótico de esplenócitos dos animais do grupo senil controle, comparados aos do grupo jovem controle, bem como, dos animais do grupo senil infectado, comparados aos do grupo jovem infectado (9 e 16 dias).

$\mathrm{Na}$ avaliação do processo de apoptose tardia, observamos um aumento significativo no percentual de células esplênicas em apoptose, tanto nos grupos senis controle e infectado, quando comparados aos animais dos grupos jovens (infectados e não infectados) (figura 12B). 
Figura 12: Marcação de células esplênicas de ratos Wistar utilizando anexina $V$ e iodeto de propídeo, durante o $9^{\circ}$ e $16^{\circ}$ dia após a infecção nos seguintes grupos: Jovem Controle (JC), Senil Controle (SC), Jovem Infectado (JI) e Senil Infectado (SI). One-way ANOVA seguido do pós-teste de Bonferroni, com ${ }^{*} p<0,5,{ }^{* *} p<0,01$ e ${ }^{* * *} p<0,001$. Todos os dados expressam a média \pm SEM. $n=5$ animais por grupo.

(A) Apoptose inicial

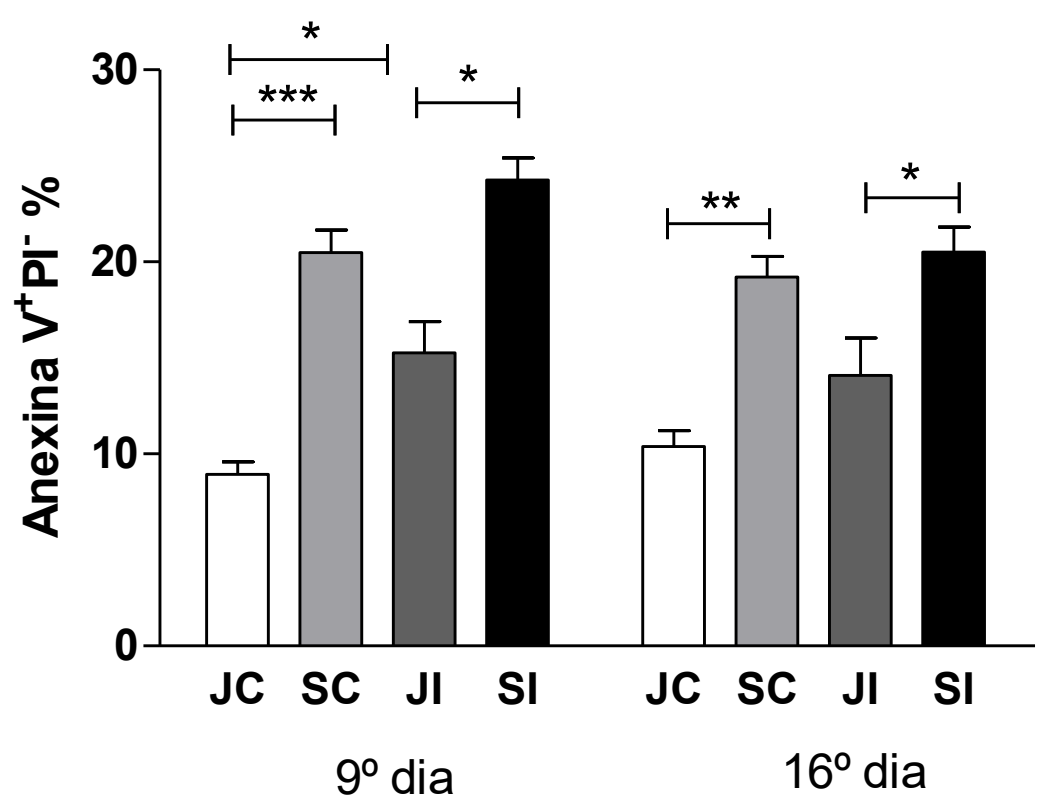

(B) Apoptose tardia

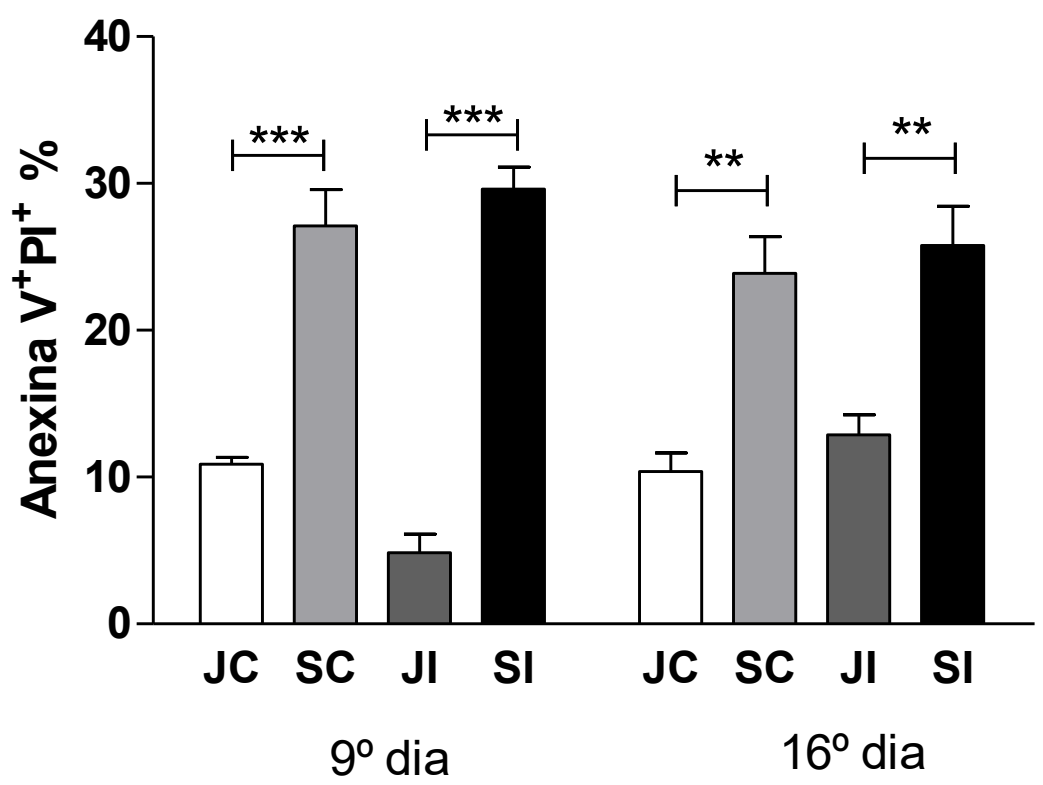




\subsection{Análise da população de esplenócitos viáveis}

A partir da utilização dos marcadores Anexina $\mathrm{V}$ e PI também foi possível identificar os esplenócitos viáveis, ou seja, Anexina V/FITC e PI negativas. Em nossos experimentos, observamos uma redução no percentual de esplenócitos viáveis (9 e 16 dias após a infecção) nos animais senis, tanto controles quanto infectados, quando comparados aos animais jovens controle (figura 13). 
Figura 13: Porcentagem de esplenócitos viáveis de ratos Wistar utilizando anexina $\mathrm{V}$ e iodeto de propídeo, durante o $9^{\circ}$ e $16^{\circ}$ dia após a infecção nos seguintes grupos: Jovem Controle (JC), Senil Controle (SC), Jovem Infectado (JI) e Senil Infectado (SI). One-way ANOVA seguido do pós-teste de Bonferroni, com ${ }^{*} p<0,5$. Todos os dados expressam a média \pm SEM. $n=5$ animais por grupo.

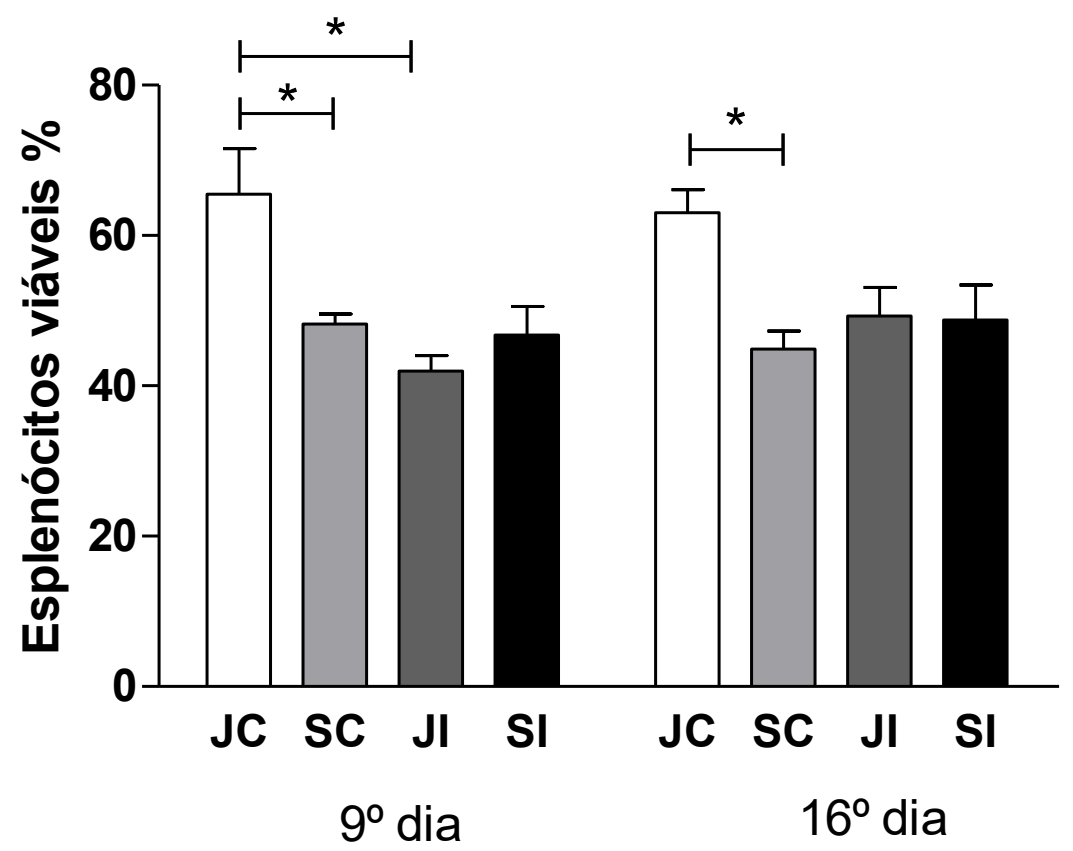




\subsection{Caracterização do processo de diferenciação intratímica}

Através da análise da expressão de glicoproteínas de superfície CD3, CD4, CD8, CD25 e CD44 em timócitos, por citometria de fluxo, foi possível a identificação dos principais eventos de diferenciação intratímica.

A figura 14A demonstra que o envelhecimento promoveu alterações marcantes no timo, resultando em redução no peso deste órgão nos animais senis, quando comparados aos animais jovens. O mesmo pode-se observar em relação ao número de timócitos (figura 14B). 
Figura 14: Peso do timo $(\mathrm{g})(\mathrm{A})$ e número de timócitos $\left(\mathrm{mm}^{3}\right)(\mathrm{B})$ em ratos Wistar machos jovens e senis não infectados e infectados com $1 \times 10^{5}$ formas tripomastigotas sanguícolas da cepa $\mathrm{Y}$ de Trypanosoma cruzi, durante o $9^{\circ}$ e $16^{\circ}$ dia após a infecção nos seguintes grupos: Jovem Controle (JC), Senil Controle (SC), Jovem Infectado (JI) e Senil Infectado (SI). Oneway ANOVA seguido do pós-teste de Bonferroni, com ${ }^{*} p<0,05,{ }^{* *} p<0,01$ e ${ }^{* * *} p<0,001$. Todos os dados expressam a média \pm SEM. $n=5$ animais por grupo.

\section{(A) Peso do Timo}

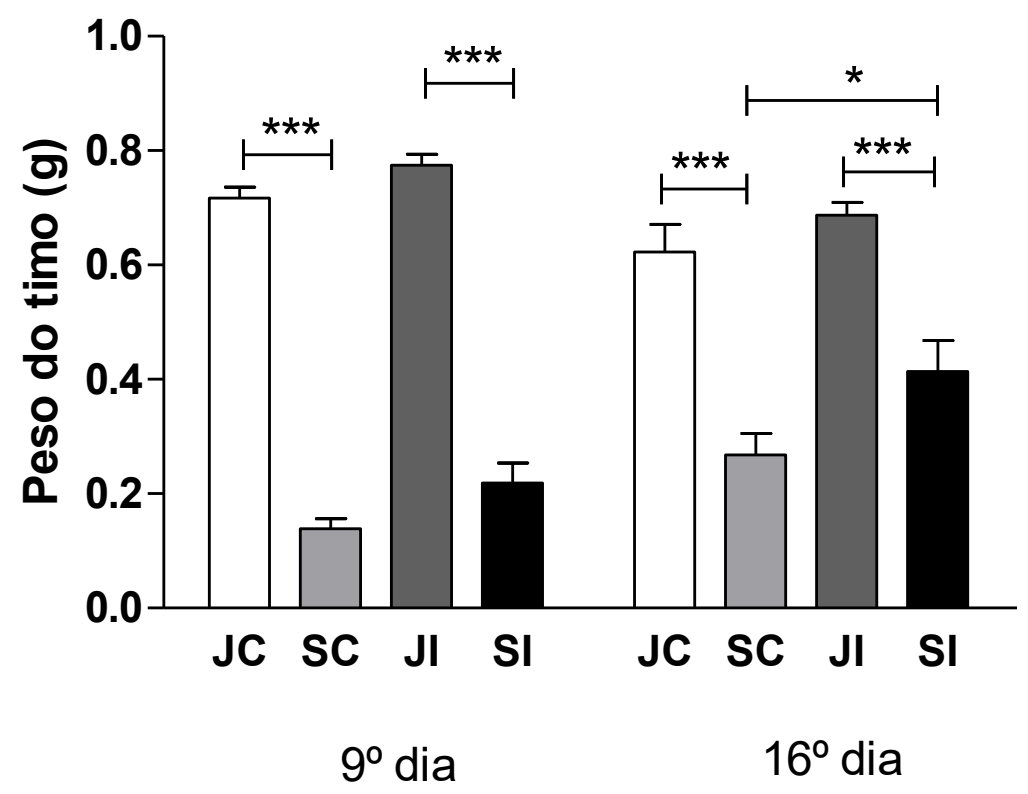

(B) Número de timócitos

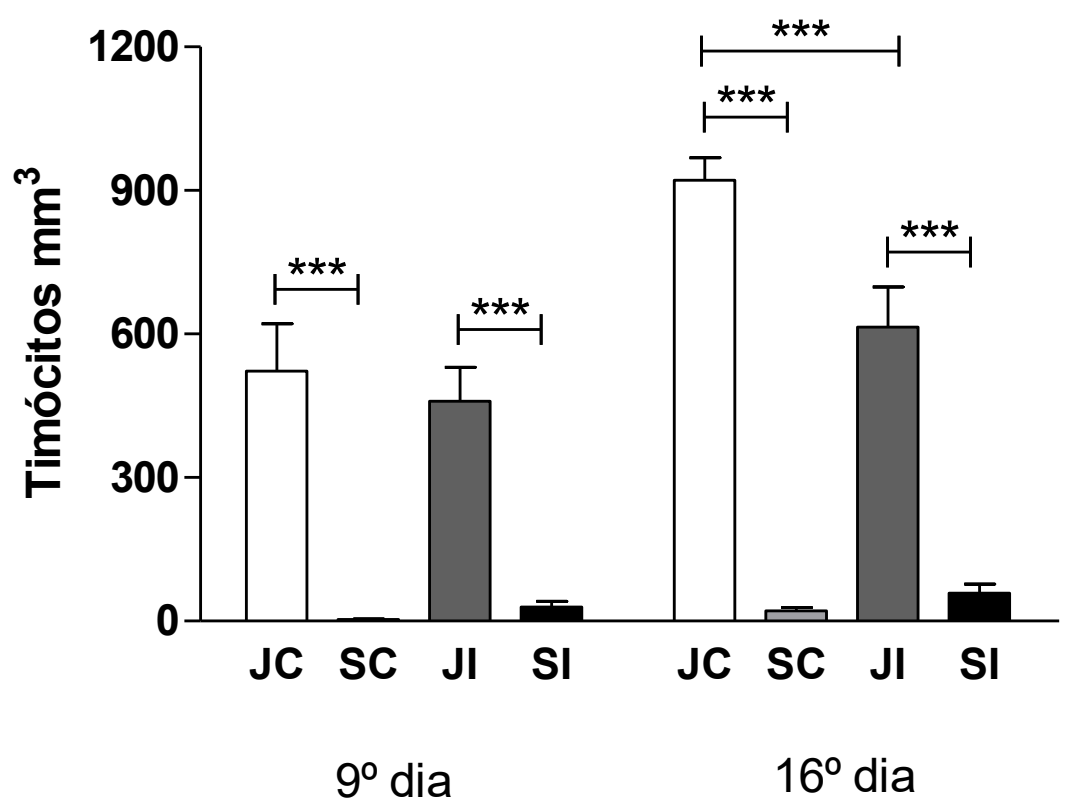


Nossos resultados confirmaram que o envelhecimento ocasionou importantes alterações no processo de diferenciação no timo, regulando negativamente a transição DN1-DN2, fato observado pela expansão de células T DN1 (figura 15A), em animais senis, infectados ou não, quando comparados aos animais jovens. Adicionalmente, nos animais jovens não foram observadas alterações significativas no percentual de timócitos DN1.

A figura 15 (B e C) demonstra que o processo de envelhecimento também foi associado a uma importante redução nas subpopulações de timócitos DN3 e DN4, como observado nos animais senis, infectados ou não, quando comparados aos animais jovens.

Alterações tímicas induzidas pela idade também afetaram a subpopulação de timócitos DP $\left(\mathrm{CD}^{+} \mathrm{CD} 4^{+} \mathrm{CD} 8^{+}\right)$nos grupos de animais controle e infectados, com redução nos percentuais destas subpopulações, quando comparados aos animais jovens, em ambos os dias de experimentos (figura 16).

Adicionalmente, foram observados nos estudos de timócitos CD4+SP (figura 17A) uma redução significativa nos percentuais dessas células nos animais do grupo senil controle, quando comparados aos grupos jovens controle ( 9 e 16 dias após a infecção). Já os timócitos $\mathrm{CD}^{+} \mathrm{SP}$ (figura 17B), observamos uma redução significativa nessas células dos animais senis infectados ou não, quando comparados aos respectivos animais do grupo jovem.

Entretanto, foi demonstrada uma significante expansão de timócitos CD3+DN em animais senis e infectados, em comparação aos animais senis não infectados, confirmando que a infecção resulta no aumento da população de timócitos DN (figura 18). 
Figura 15: Caracterização de timócitos DN1 (A), DN3 (B) e DN4 (C) em ratos Wistar machos jovens e senis não infectados e infectados com $1 \times 10^{5}$ formas tripomastigotas sanguícolas da cepa $Y$ de Trypanosoma cruzi, no $9^{\circ}$ e $16^{\circ}$ dia após a infecção nos seguintes grupos: Jovem Controle (JC), Senil Controle (SC), Jovem Infectado (JI) e Senil Infectado (SI). One-way ANOVA seguido do pós-teste de Bonferroni, com ${ }^{*} p<0,05,{ }^{* *} p<0,01$ e ${ }^{* *} p<0,001$. Todos os dados expressam a média \pm SEM. $n=5$ animais por grupo.

(A) Timócitos DN1

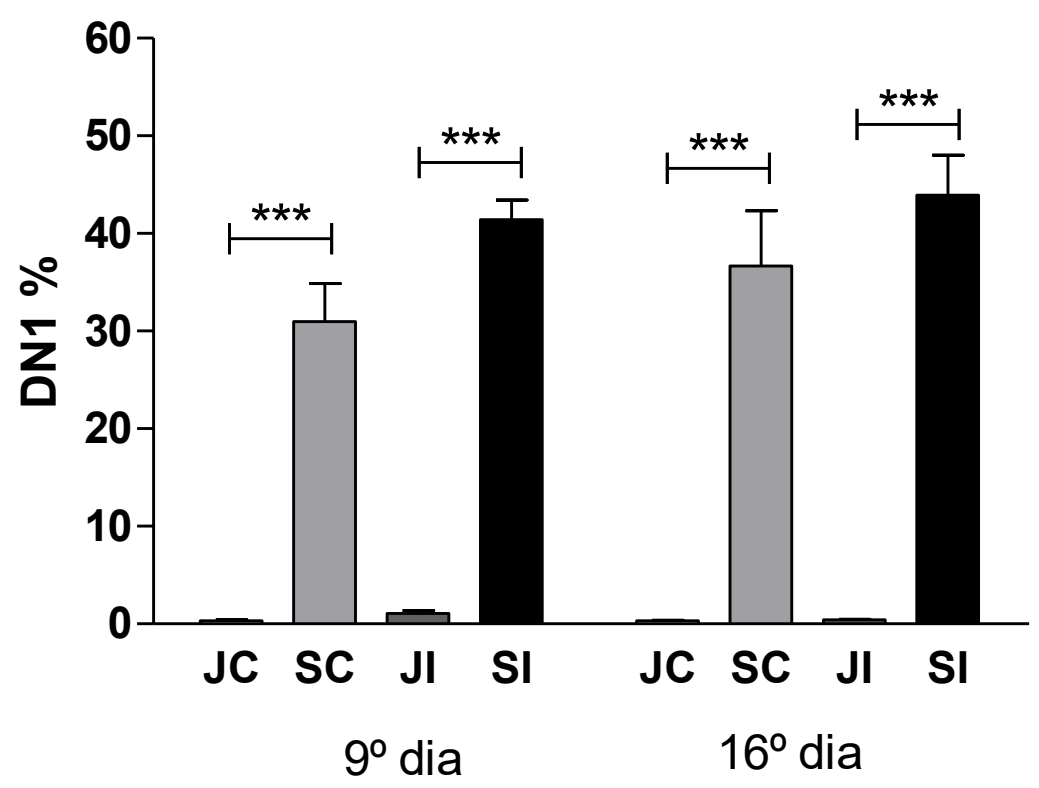

(B) Timócitos DN3

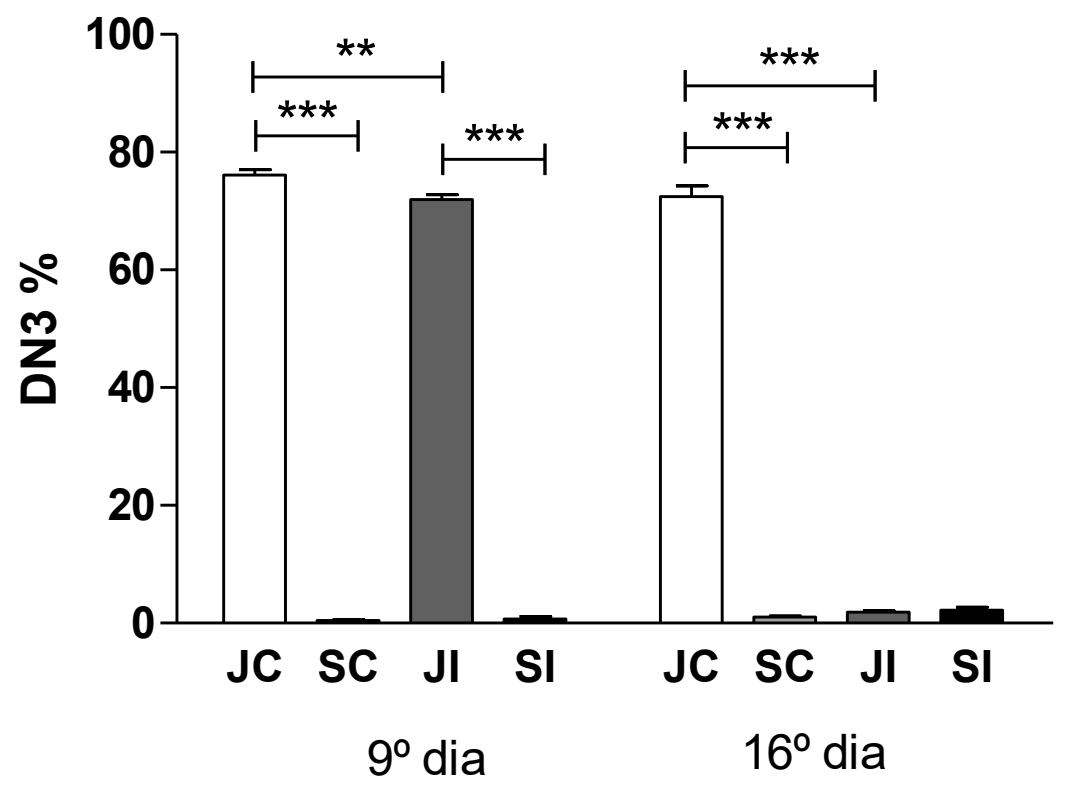


(C) Timócitos DN4

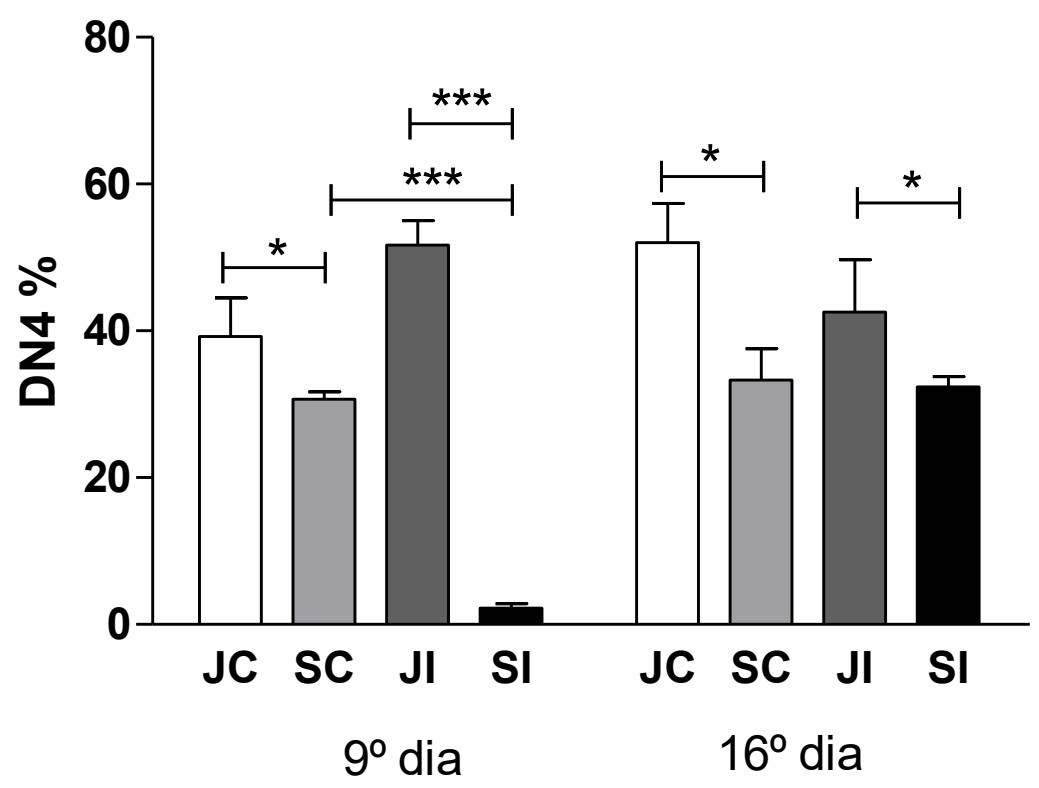


Figura 16: Caracterização de timócitos DP $\left(C D 3^{+} C D 4^{+} C D 8^{+}\right)$em ratos Wistar machos jovens e senis não infectados e infectados com $1 \times 10^{5}$ formas tripomastigotas sanguícolas da cepa $Y$ de Trypanosoma cruzi, no $9^{\circ}$ e $16^{\circ}$ dia após a infecção nos seguintes grupos: Jovem Controle (JC), Senil Controle (SC), Jovem Infectado (JI) e Senil Infectado (SI). One-way ANOVA seguido do pós-teste de Bonferroni, com ${ }^{*} p<0,05,{ }^{* *} p<0,01 e^{* * *} p<0,001$. Todos os dados expressam a média \pm SEM. $n=5$ animais por grupo.

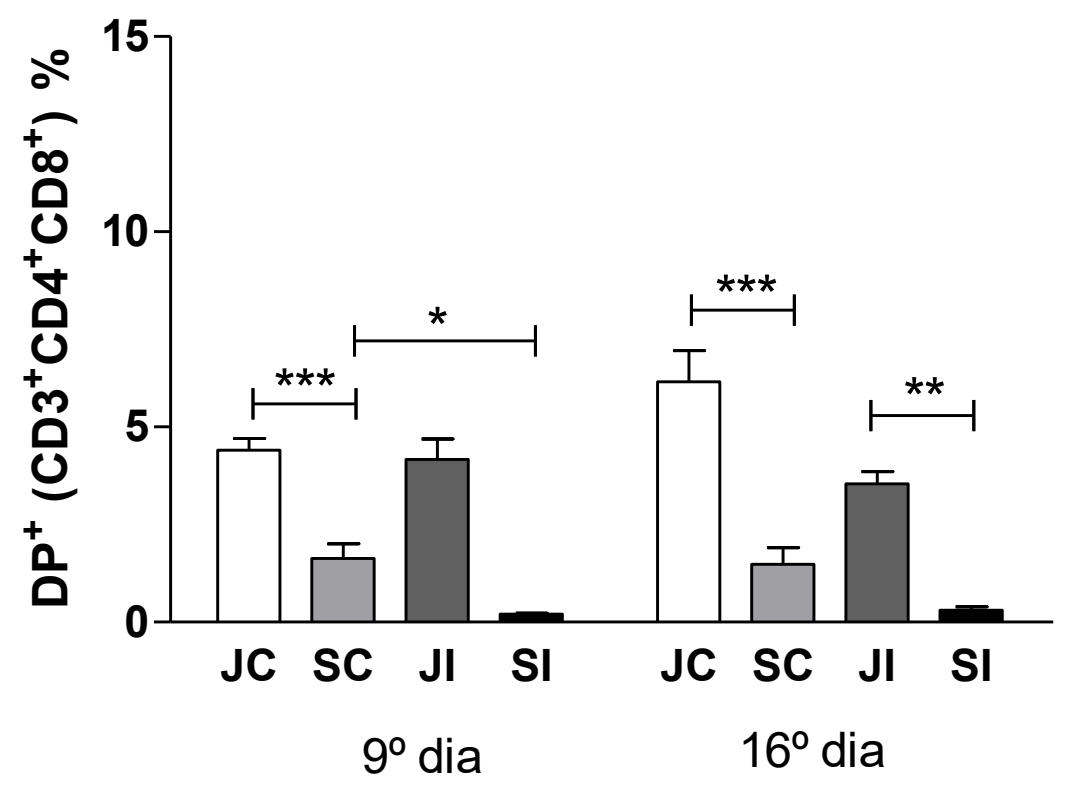


Figura 17: Porcentagem de timócitos $C D 4^{+} S P(A)$ e $C D 8^{+} S P(B)$ em ratos Wistar machos jovens e senis não infectados e infectados com $1 \times 10^{5}$ formas tripomastigotas sanguícolas da cepa $Y$ de Trypanosoma cruzi, no $9^{\circ}$ e $16^{\circ}$ dia após a infecção nos seguintes grupos: Jovem Controle (JC), Senil Controle (SC), Jovem Infectado (JI) e Senil Infectado (SI). One-way ANOVA seguido do pós-teste de Bonferroni, com ${ }^{*} p<0,05,{ }^{* *} p<0,01$ e ${ }^{* * *} p<0,001$. Todos os dados expressam a média \pm SEM. $n=5$ animais por grupo.

\section{(A) Timócitos simples positivo CD4 ${ }^{+}$}

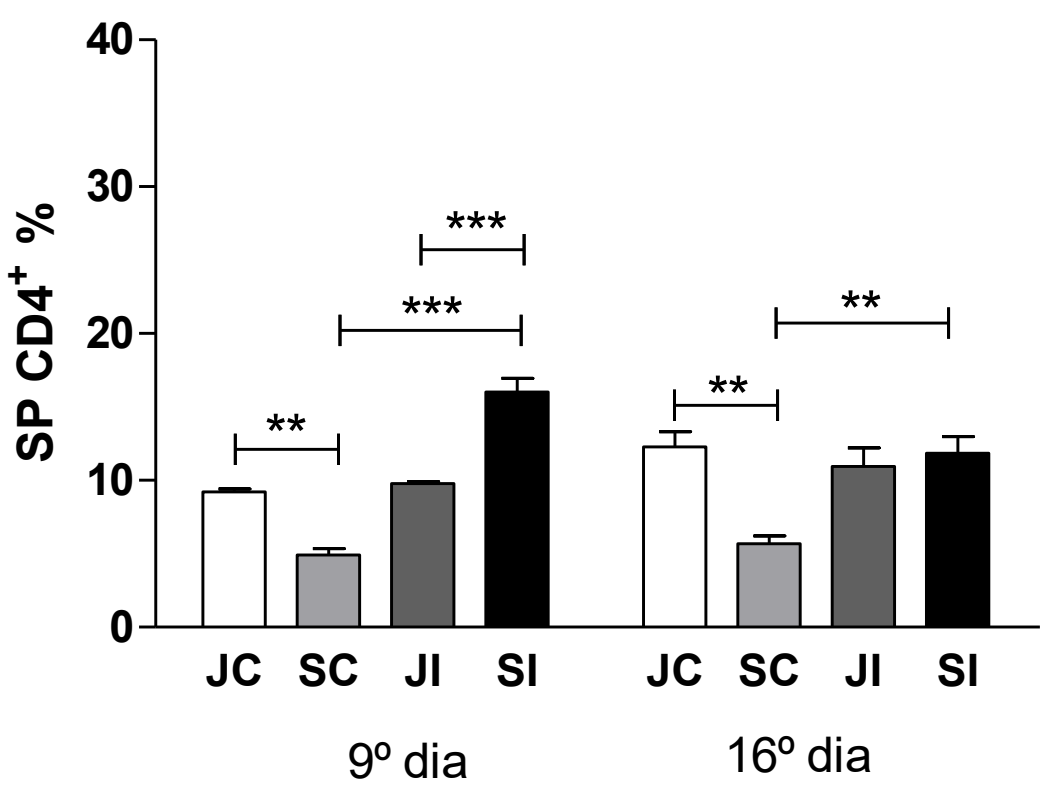

(B) Timócitos simples positivo CD8 ${ }^{+}$

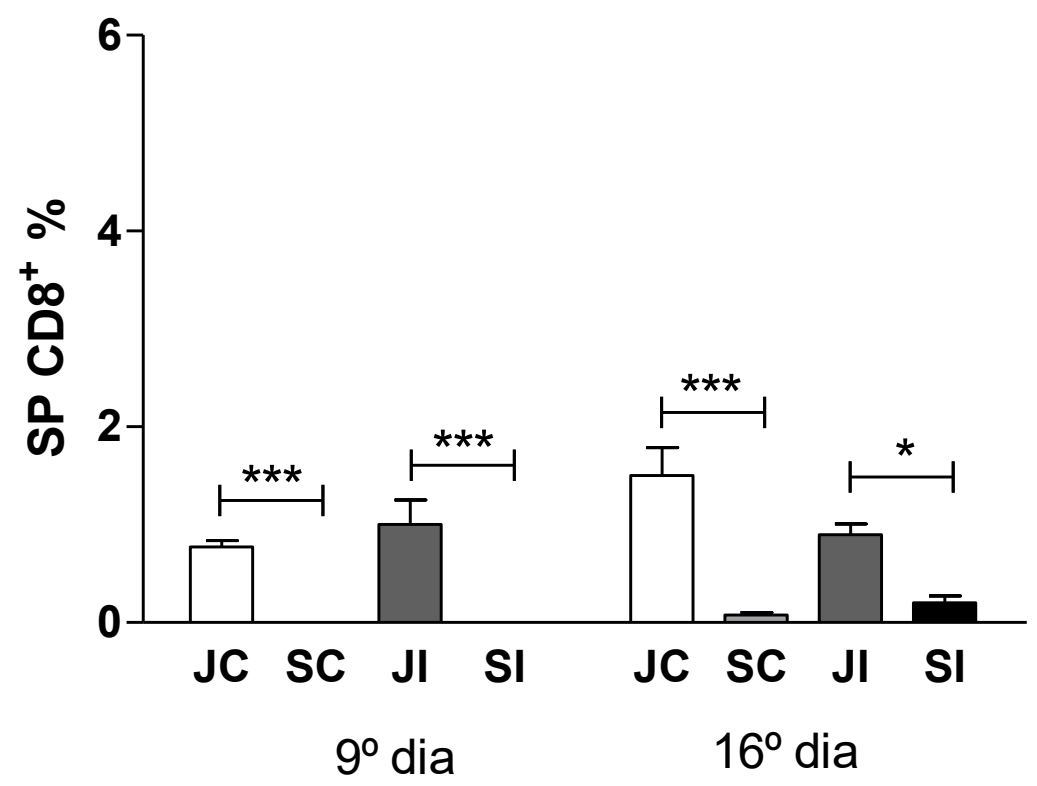


Figura 18: Porcentagem de timócitos $C D 3^{+} D N$ em ratos Wistar machos jovens e senis não infectados e infectados com $1 \times 10^{5}$ formas tripomastigotas sanguícolas da cepa $Y$ de Trypanosoma cruzi, no $9^{\circ}$ e $16^{\circ}$ dia após a infecção nos seguintes grupos: Jovem Controle (JC), Senil Controle (SC), Jovem Infectado (JI) e Senil Infectado (SI). One-way ANOVA seguido do pós-teste de Bonferroni, com ${ }^{*} \mathrm{p}<0,05$. Todos os dados expressam a média \pm SEM. $\mathrm{n}=5$ animais por grupo.

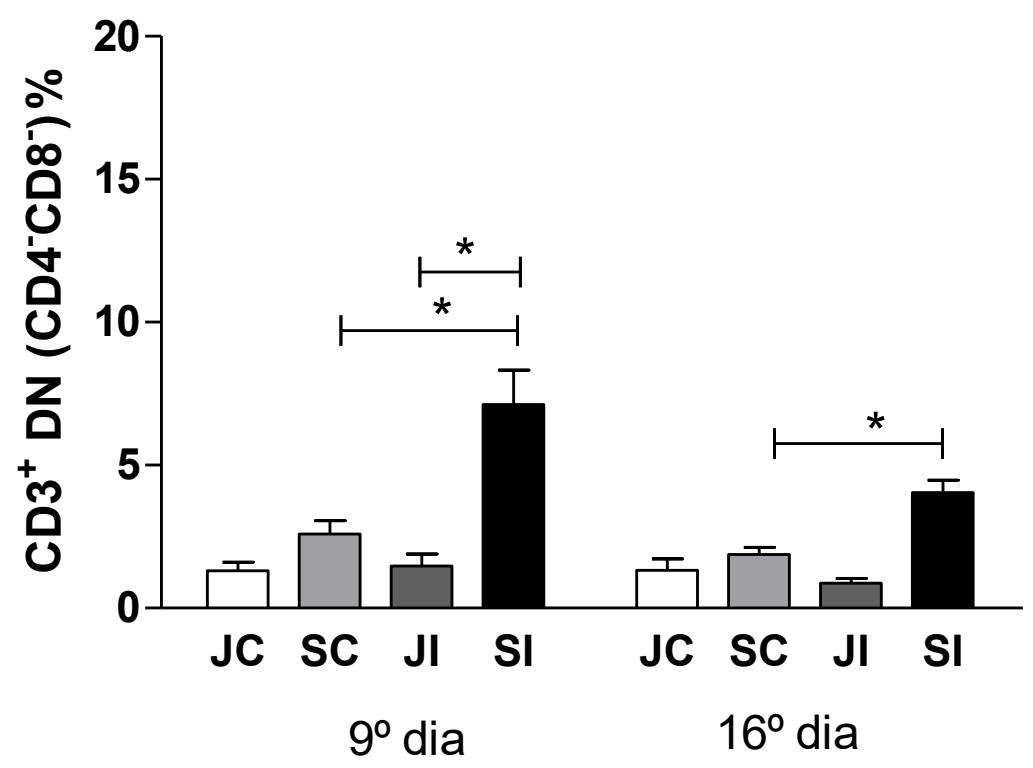




\subsection{Análise do processo de apoptose no timo}

Durante a evolução da infecção experimental, observamos um aumento significativo no percentual de timócitos em estágio inicial e tardio de apoptose nos grupos senis controle e infectado, quando comparados aos animais dos grupos jovens (infectado e não infectado) (figura 19A e 19B). 
Figura 19: Porcentagem de timócitos de ratos Wistar utilizando anexina $\mathrm{V}$ e iodeto de propídeo, durante o $9^{\circ}$ e $16^{\circ}$ dia após a infecção nos seguintes grupos: Jovem Controle (JC), Senil Controle (SC), Jovem Infectado (JI) e Senil Infectado (SI). One-way ANOVA seguido do pós-teste de Bonferroni, com ${ }^{* *} p<0,01 e^{* * *} p<0,001$. Todos os dados expressam a média \pm SEM. $\mathrm{n}=5$ animais por grupo.

(A)Apoptose inicial

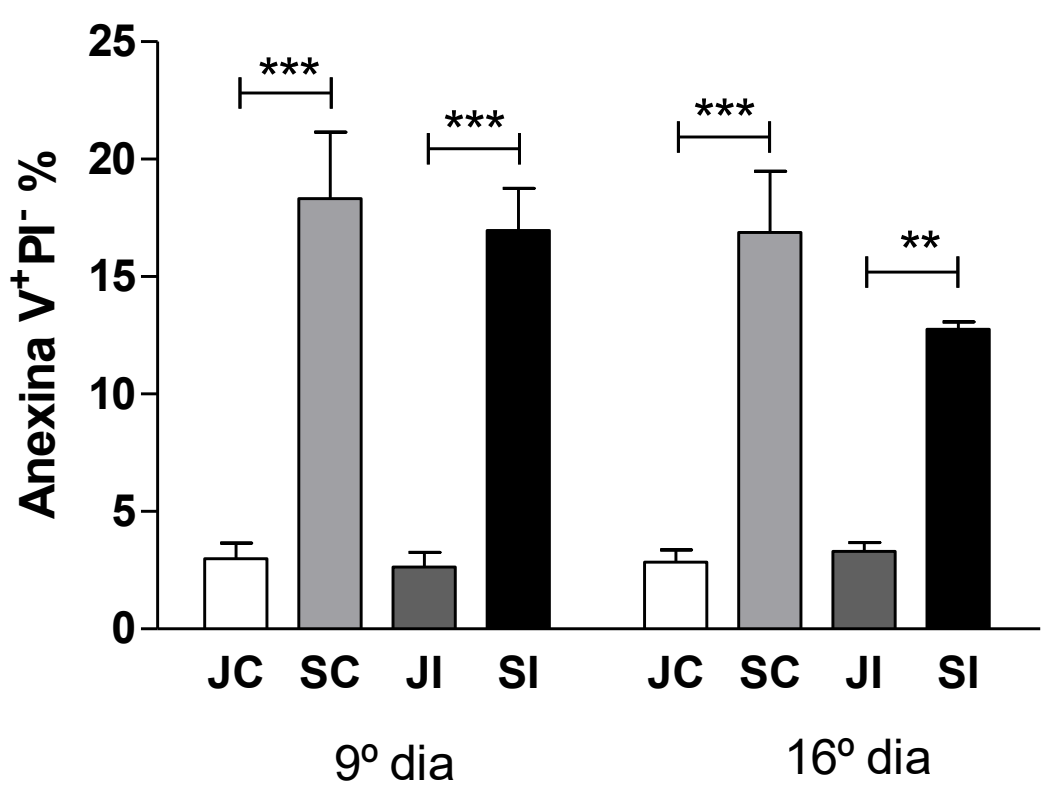

(B) Apoptose tardia

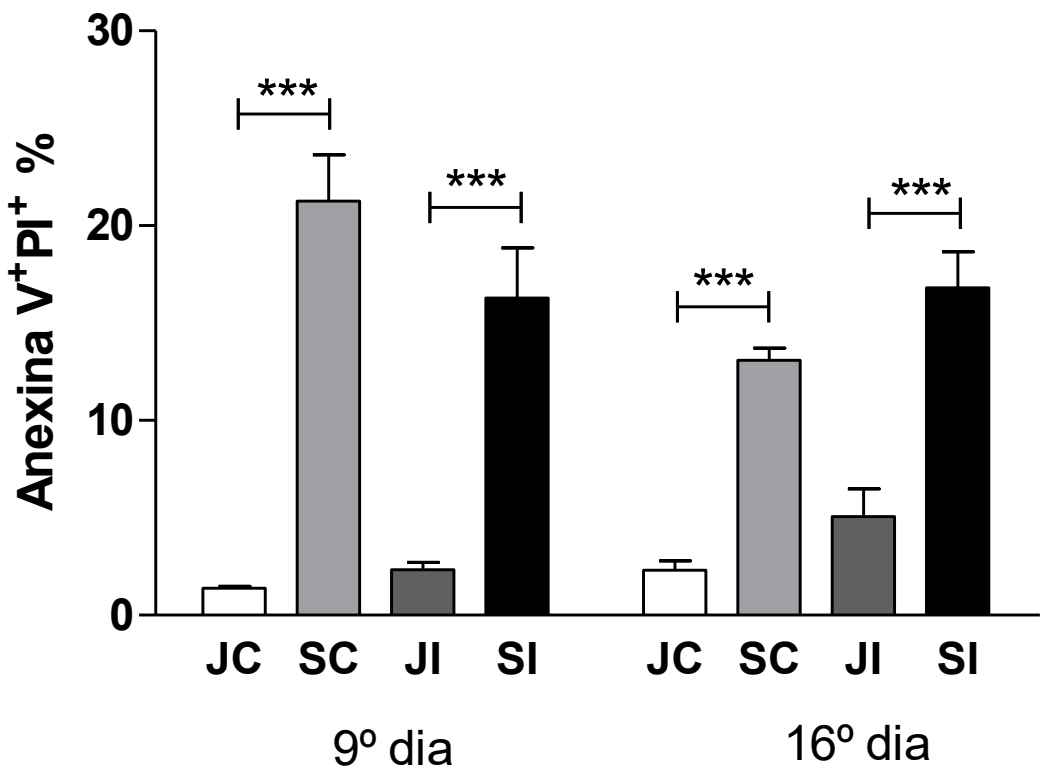




\subsection{Análise da população de timócitos viáveis}

A partir da utilização dos marcadores Anexina $\mathrm{V}$ e PI também foi possível identificar a viabilidade dos timócitos, ou seja, Anexina V/FITC e PI negativas. Em nossos experimentos, observamos uma redução no percentual de timócitos viáveis (9 e 16 dias após a infecção) nos animais senis, tanto controles quanto infectados, quando comparados aos animais jovens (figura 20). 
Figura 20: Porcentagem de timócitos viáveis de ratos Wistar utilizando anexina $\mathrm{V}$ e iodeto de propídeo, durante o $9^{\circ}$ e $16^{\circ}$ dia após a infecção nos seguintes grupos: Jovem Controle (JC), Senil Controle (SC), Jovem Infectado (JI) e Senil Infectado (SI). One-way ANOVA seguido do pós-teste de Bonferroni, com ${ }^{* *} p<0,01 e^{* * *} p<0,001$. Todos os dados expressam a média \pm SEM. $n=5$ animais por grupo.

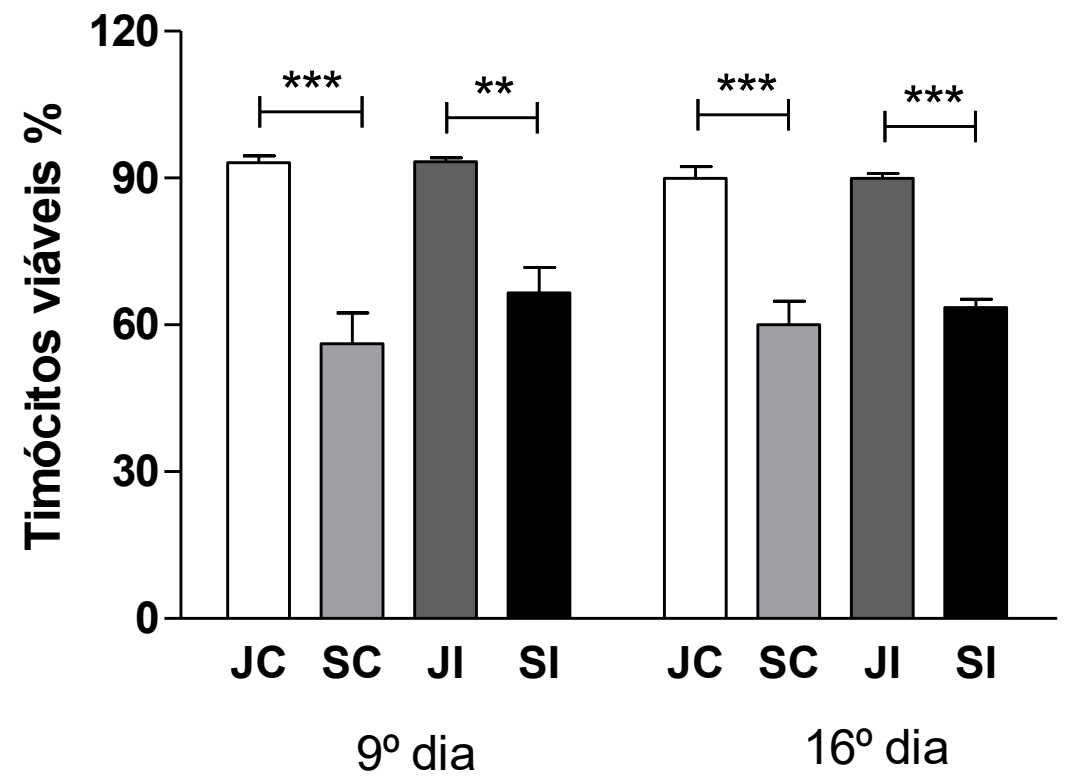




\subsection{Quantificação indireta de óxido nítrico}

No $9^{\circ}$ dia após a infecção, observamos um aumento significativo nas concentrações de nitrito, obtidos a partir do lavado peritoneal, nos animais jovens e infectados, quando comparados aos animais jovens não infectados $\left({ }^{* *} p<0,001\right)$. Por outro lado, os animais senis infectados apresentaram uma redução dos níveis de nitrito (9 dias), quando comparado aos animais jovens e infectados $\left({ }^{* *} p<0,01\right)$.

No $16^{\circ}$ dia após o inóculo, a concentração de nitrito nos animais senis infectados permaneceu semelhante ao valor encontrado no $9^{\circ}$ após a infecção, sendo significativamente maior quando comparado aos animais jovens infectados $\left({ }^{*} p<0,05\right)$ (figura 21). 
Figura 21: Análise indireta da concentração de óxido nítrico no lavado peritoneal de ratos Wistar machos jovens e senis não infectados e infectados com $1 \times 10^{5}$ formas tripomastigotas sanguícolas da cepa $Y$ de Trypanosoma cruzi, no $9^{\circ}$ e $16^{\circ}$ dia após a infecção nos seguintes grupos: Jovem Controle (JC), Senil Controle (SC), Jovem Infectado (JI) e Senil Infectado (SI). One-way ANOVA seguido do pós-teste de Bonferroni, com ${ }^{*} p<0,05,{ }^{* *} p<0,01$ e ${ }^{* *} p<0,001$. Todos os dados expressam a média \pm SEM. $n=5$ animais por grupo.

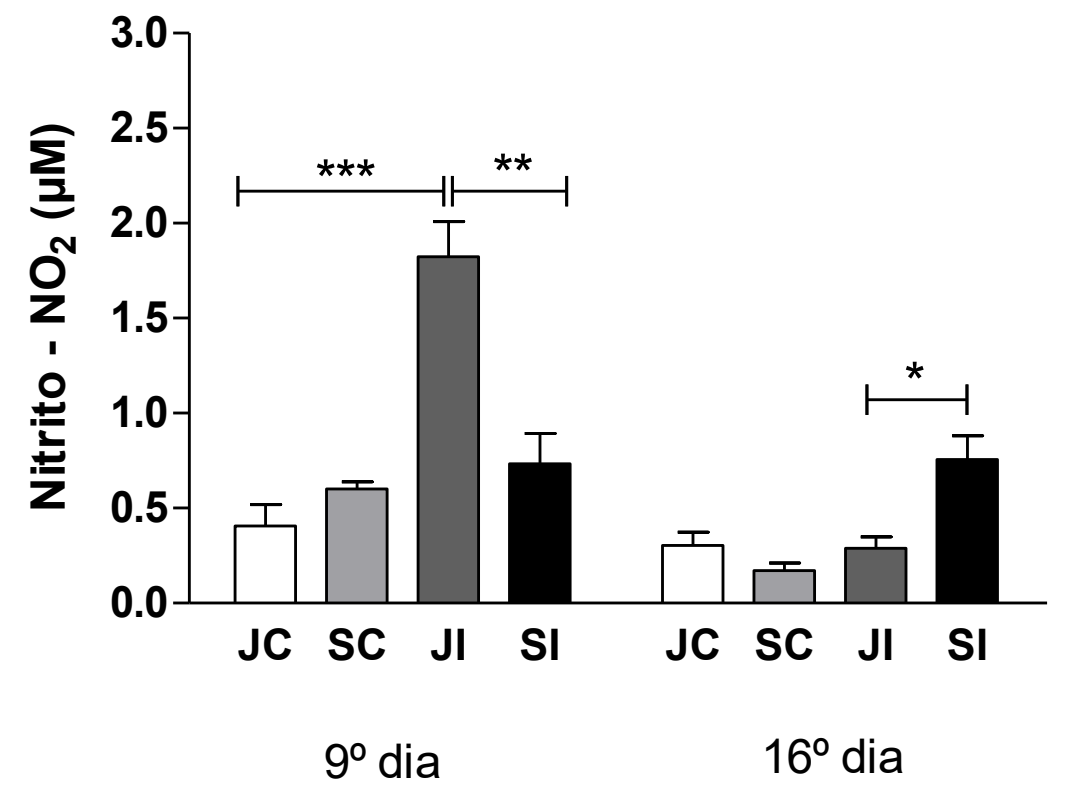




\subsection{Quantificação de óxido nítrico no soro}

Nestes experimentos, obtivemos um aumento significativo nas concentrações de óxido nítrico no soro de animais jovens e infectados, 9 dias após a infecção por T.cruzi, quando comparados aos jovens não infectados $\left({ }^{* *} p<0,01\right)$. Podemos observar uma tendência de aumento de óxido nítrico nos animais senis controle, quando comparados aos jovens controle ( $9^{\circ}$ dia de experimento), sendo que este resultado foi significativo no $16^{\circ}$ dia de experimento. Já nos animais senis e infectados, a concentração de óxido nítrico permaneceu semelhante aos valores observados aos 9 dias após a infeção, sendo significativamente maior que o encontrado nos animais jovens infectados (figura 22). 
Figura 22: Análise indireta da concentração de óxido nítrico no soro de ratos Wistar machos jovens e senis não infectados e infectados com $1 \times 10^{5}$ formas tripomastigotas sanguícolas da cepa $Y$ de Trypanosoma cruzi, no $9^{\circ}$ e $16^{\circ}$ dia após a infecção nos seguintes grupos: Jovem Controle (JC), Senil Controle (SC), Jovem Infectado (JI) e Senil Infectado (SI). One-way ANOVA seguido do pós-teste de Bonferroni, com ${ }^{*} p<0,05$ e ${ }^{* *} p<0,01$. Todos os dados expressam a média \pm SEM. $n=5$ animais por grupo.

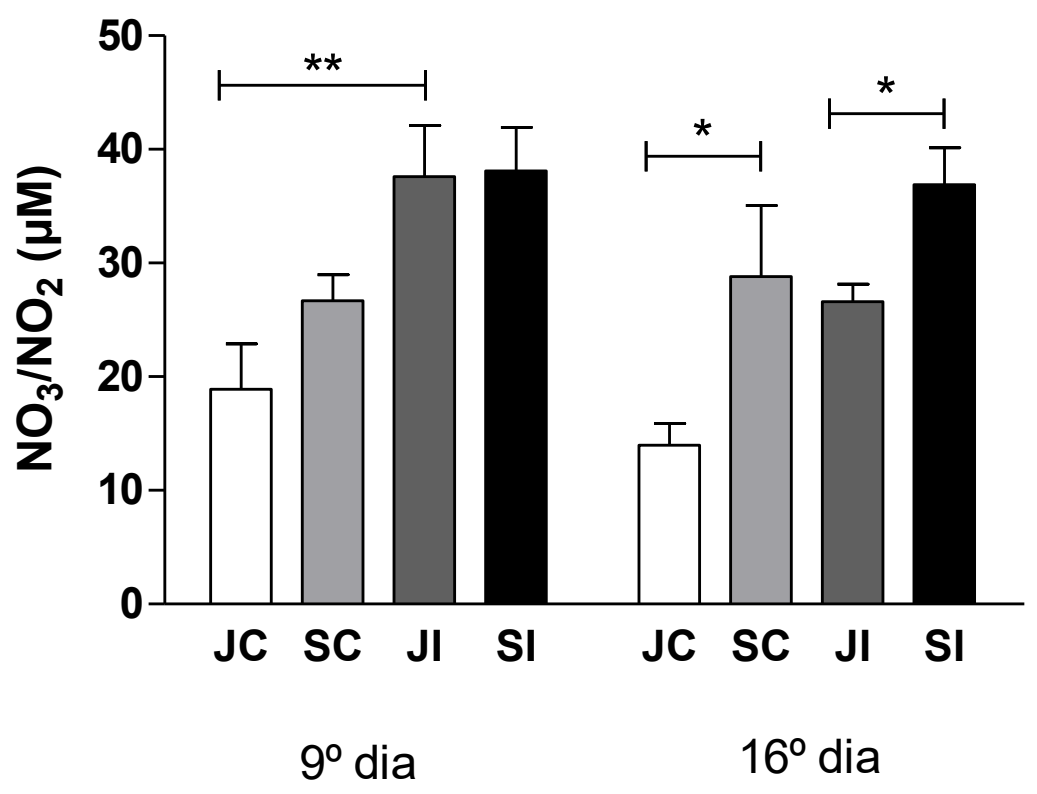


6.16. Análise das concentrações das substâncias reativas ao ácido tiobarbitúrico (TBARS)

Outro objetivo deste estudo foi determinar se o envelhecimento está associado a alterações no início e/ou progressão da peroxidação lipídica. No $16^{\circ}$ dia de experimento, os animais senis demonstraram uma tendência não significativa para um aumento nas concentrações de TBARS no plasma, em comparação com os animais jovens e não infectados. Ainda, podemos observar níveis mais elevados e significativos de TBARS nos animais senis infectados, quando comparados aos seus controles $\left({ }^{*} p<0,05\right)$ e aos infectados jovens $\left({ }^{* * *} p<0,001\right)$. 
Figura 23: Análise da peroxidação lipídica, através da concentração das substâncias reativas ao ácido tiobarbitúrico (TBARS), no plasma de ratos Wistar machos jovens e senis não infectados e infectados com $1 \times 10^{5}$ formas tripomastigotas sanguícolas da cepa $Y$ de Trypanosoma cruzi, no $16^{\circ}$ dia após a infecção nos seguintes grupos: Jovem Controle (JC), Senil Controle (SC), Jovem Infectado (JI) e Senil Infectado (SI). One-way ANOVA seguido do pós-teste de Bonferroni, com ${ }^{*} p<0,05 e^{* * *} p<0,001$. Todos os dados expressam a média \pm SEM. $\mathrm{n}=5$ animais por grupo.

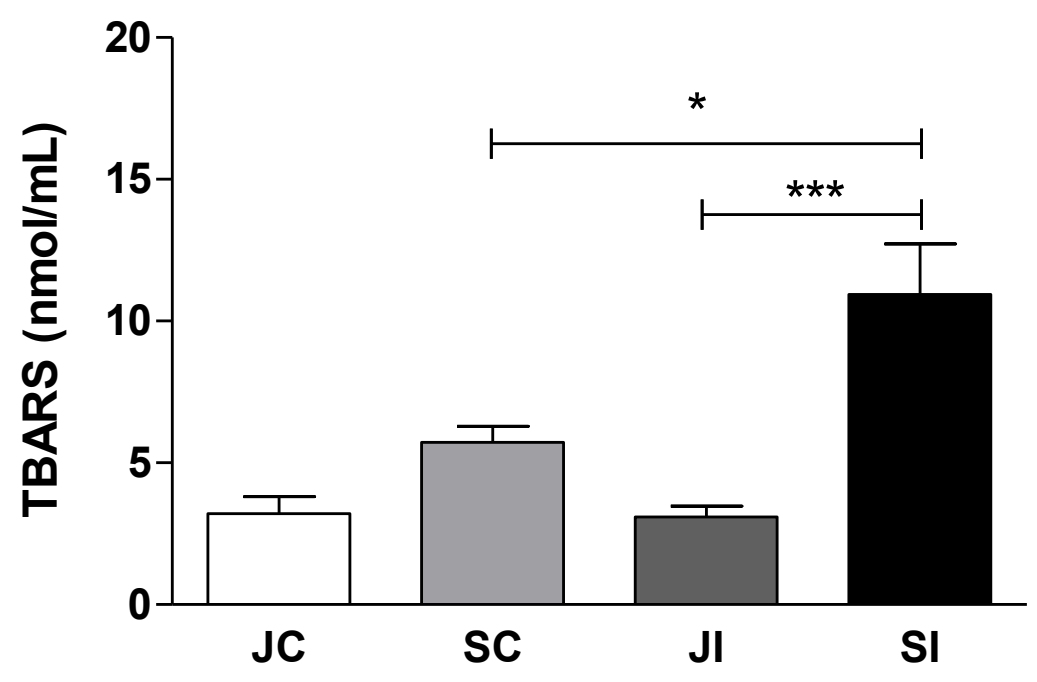

$16^{\circ}$ dia 


\subsection{Avaliação plasmática da atividade da Superóxido Dismutase (SOD)}

Para determinar se o envelhecimento promove alterações na atividade enzimática da SOD, foram analisadas as porcentagens de inibição da atividade esta enzima por $\mathrm{mL}$ de plasma. No $9^{\circ}$ de experimento, os animais senis controle apresentaram uma redução significativa na atividade da SOD quando comparados aos jovens não infectados $\left({ }^{* *} p<0,01\right)$. No $16^{\circ}$ dia após a infecção, podemos observar uma redução significativa na atividade desta enzima no grupo senil tanto controle quanto infectado, quando comparados aos jovens infectados $\left({ }^{* *} p<0,01\right)$ e não infectados $\left({ }^{*} \mathrm{p}<0,05\right)$. 
Figura 24: Avaliação da atividade da enzima Superóxido dismutase (SOD) através da porcentagem de inibição no plasma de ratos Wistar machos jovens e senis não infectados e infectados com $1 \times 10^{5}$ formas tripomastigotas sanguícolas da cepa $Y$ de Trypanosoma cruzi, no $9^{\circ}$ e $16^{\circ}$ dia após a infecção nos seguintes grupos: Jovem Controle (JC), Senil Controle (SC), Jovem Infectado (JI) e Senil Infectado (SI). One-way ANOVA seguido do pós-teste de Bonferroni, com ${ }^{*} p<0,05$ e ${ }^{* *} p<0,01$. Todos os dados expressam a média \pm SEM. $n=5$ animais por grupo.

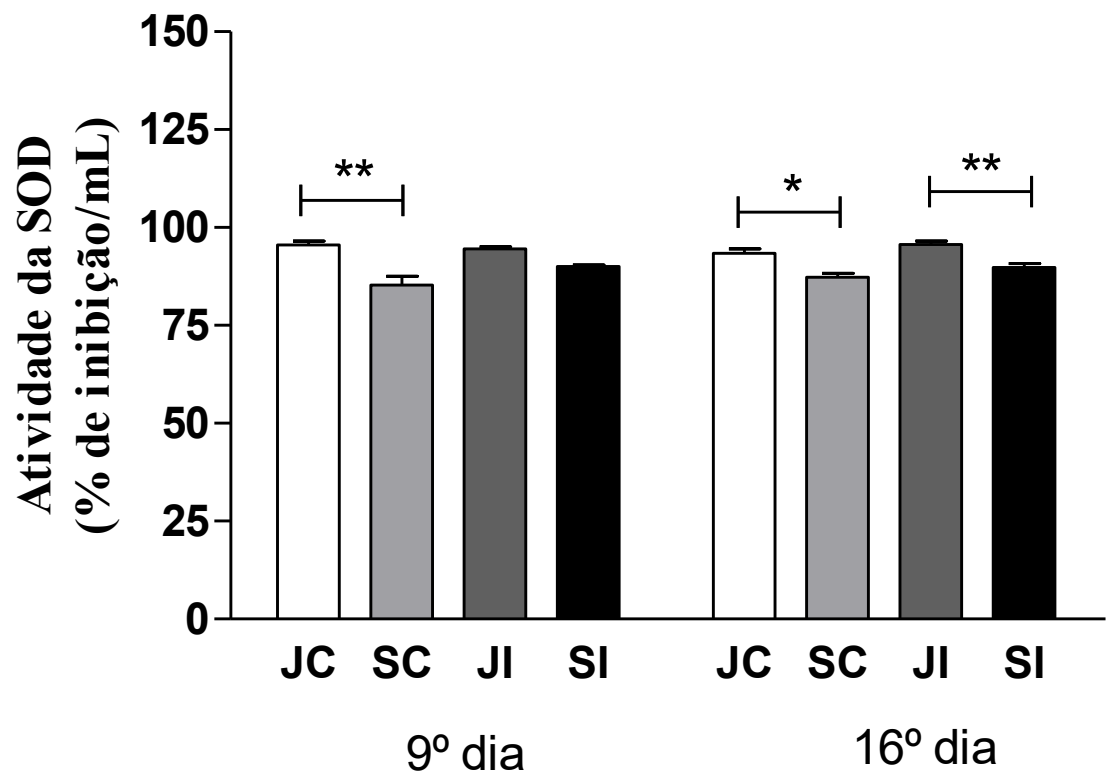




\subsection{Determinação das concentrações plasmáticas do 8-isoprostano}

A concentração de 8-isoprostano foi significativamente maior nos animais jovens infectados e senis controle, tanto 9 quanto 16 dias após a infecção, quando comparados com os animais do grupo jovem não infectados. Além disso, no $16^{\circ}$ dia, os animais senis e infectados apresentaram diminuição significativa no nível de 8isoprostano, quando comparados ao grupo jovens e infectados (figura 25). 
Figura 25: Quantificação do 8-isoprostano no plasma de ratos Wistar machos jovens e senis não infectados e infectados com $1 \times 10^{5}$ formas tripomastigotas sanguícolas da cepa $Y$ de Trypanosoma cruzi, no $9^{\circ}$ e $16^{\circ}$ dia após a infecção nos seguintes grupos: Jovem Controle (JC), Senil Controle (SC), Jovem Infectado (JI) e Senil Infectado (SI). One-way ANOVA seguido do pós-teste de Bonferroni, com ${ }^{*} p<0,05$ e ${ }^{* *} p<0,01$. Todos os dados expressam a média \pm SEM. $n=5$ animais por grupo.

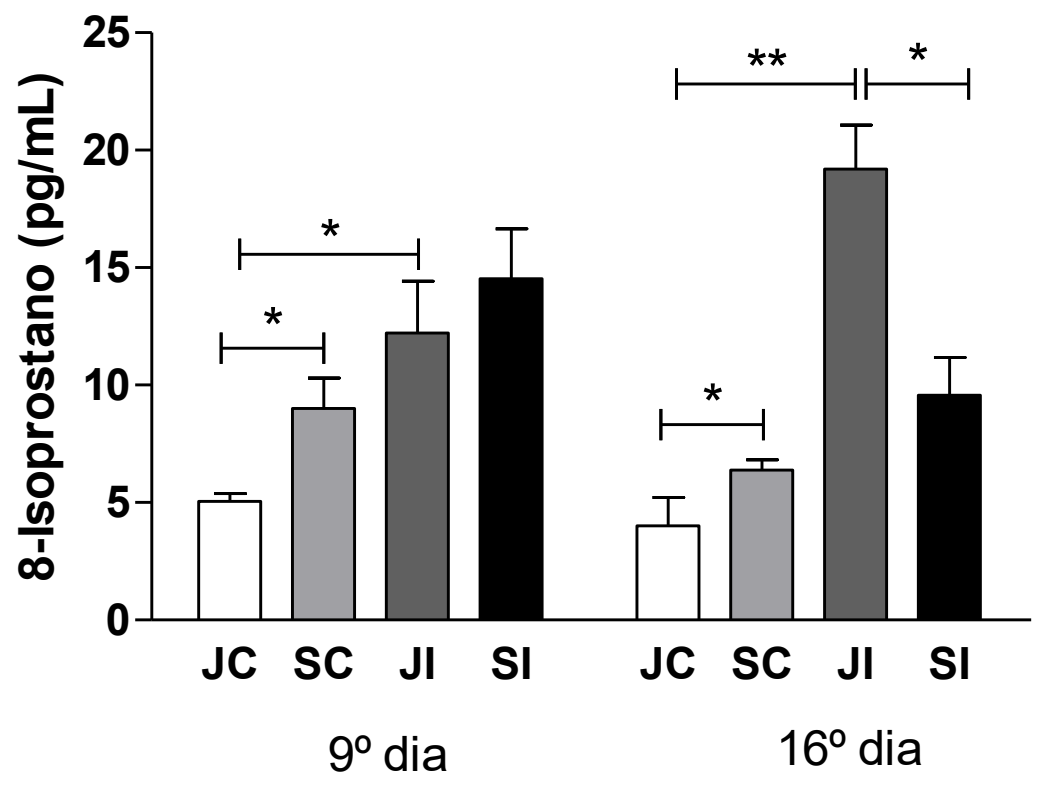




\subsection{Quantificação da Glutationa (GSH) no plasma}

Nestes experimentos, analisamos as concentrações de GSH no plasma de animais controle e infectados por T.cruzi. Podemos observar que nos animais senis controle os níveis de GSH aumentaram significativamente em relação aos animais jovens (figura 26). Além disso, a concentração de GSH foi maior nos animais jovens e infectados quando comparados aos jovens peretncentes ao grupo controle (9 e 16 dias após a infecção). 
Figura 26: Quantificação da glutationa (GSH) em $\mu \mathrm{g} / \mathrm{mL}$, no plasma de ratos Wistar machos jovens e senis não infectados e infectados com $1 \times 10^{5}$ formas tripomastigotas sanguícolas da cepa $Y$ de Trypanosoma cruzi, no $9^{\circ}$ e $16^{\circ}$ dia após a infecção nos seguintes grupos: Jovem Controle (JC), Senil Controle (SC), Jovem Infectado (JI) e Senil Infectado (SI). One-way ANOVA seguido do pós-teste de Bonferroni, com ${ }^{*} p<0,05$ e ${ }^{* * *} p<0,001$. Todos os dados expressam a média \pm SEM. $n=5$ animais por grupo.

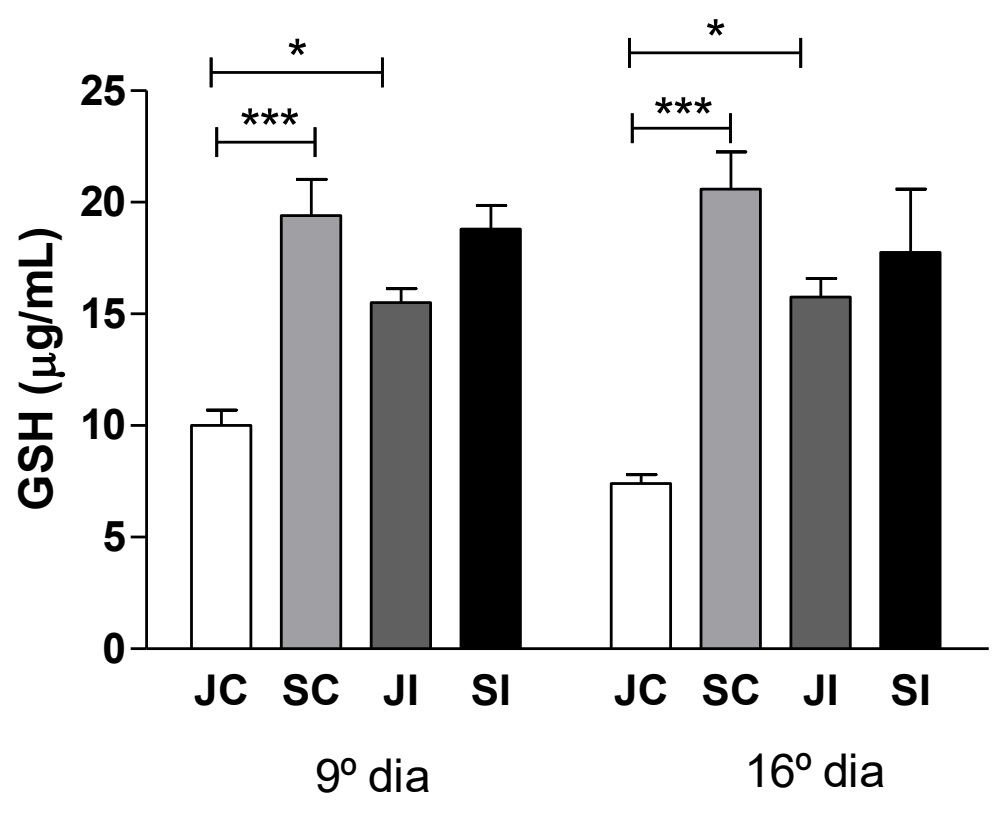


6.20. Análise das concentrações das substâncias reativas ao ácido tiobarbitúrico (TBARS) no timo

No $9^{\circ}$ dias após a infecção por $T$. cruzi, a análise das concentrações das substâncias reativas ao ácido tiobarbitúrico no tecido tímico de animais jovens e senis, infectados ou não, demonstrou que o envelhecimento não provocou progressão da peroxidação lipídica no timo. No entanto, podemos observar um aumento significativo nas concentrações de TBARS nos animais jovens infectados, em comparação com os animais jovens não infectados e senis infectados (figura 27). 
Figura 27: Análise da peroxidação lipídica, através da concentração das substâncias reativas ao ácido tiobarbitúrico (TBARS) no tecido tímico de ratos Wistar machos jovens e senis não infectados e infectados com $1 \times 10^{5}$ formas tripomastigotas sanguícolas da cepa $Y$ de Trypanosoma cruzi, no $9^{\circ}$ dia após a infecção nos seguintes grupos: Jovem Controle (JC), Senil Controle (SC), Jovem Infectado (JI) e Senil Infectado (SI). One-way ANOVA seguido do pós-teste de Bonferroni, com ${ }^{*} p<0,05$. Todos os dados expressam a média \pm SEM. $\mathrm{n}=5$ animais por grupo.

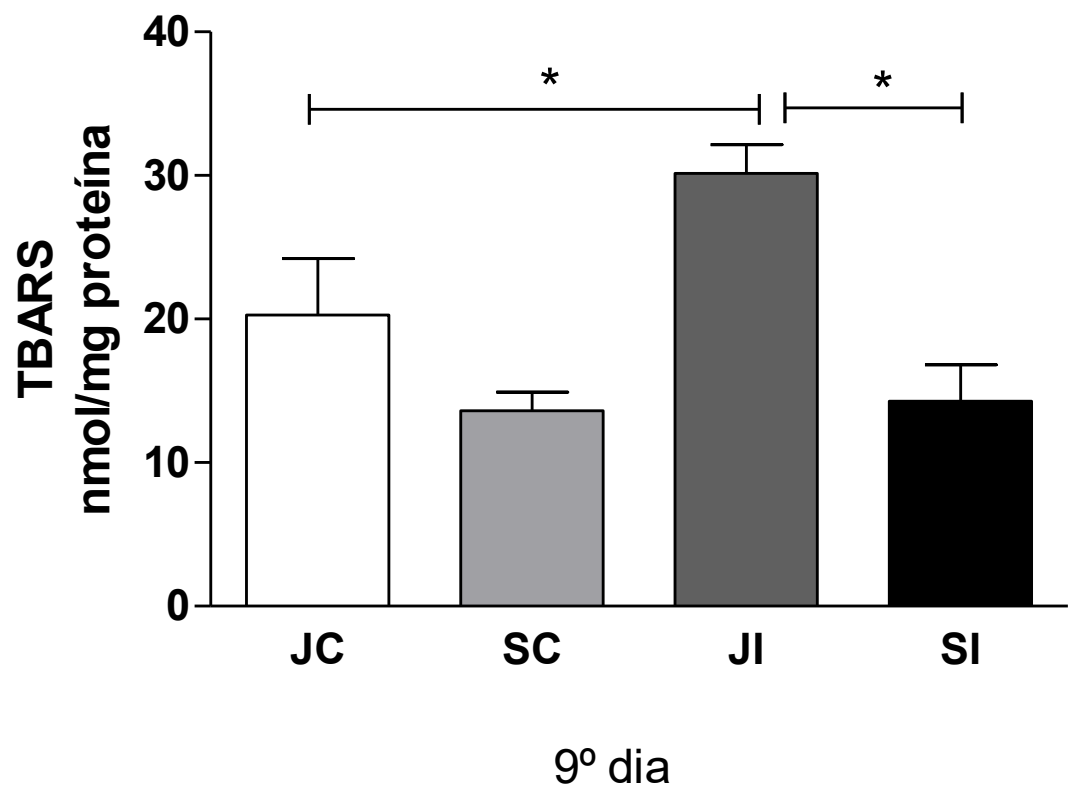




\subsection{Avaliação da atividade da Superóxido Dismutase (SOD) no timo}

Também avaliamos se o envelhecimento pode promover alterações na atividade enzimática da SOD no timo. Para tal, foram analisadas as porcentagens de inibição da atividade esta enzima por $\mathrm{U} / \mathrm{mL} / \mathrm{mg}$ de proteína de tecido tímico. No $9^{\circ}$ após a infecção, os animais senis infectados apresentaram um aumento significativo na atividade da SOD quando comparados aos senis não infectados $\left({ }^{* *} p<0,01\right)$. 
Figura 28: Avaliação da atividade da enzima Superóxido dismutase (SOD) no timo de ratos Wistar machos jovens e senis não infectados e infectados com $1 \times 10^{5}$ formas tripomastigotas sanguícolas da cepa $Y$ de Trypanosoma cruzi, no $9^{\circ}$ dia após a infecção nos seguintes grupos: Jovem Controle (JC), Senil Controle (SC), Jovem Infectado (JI) e Senil Infectado (SI). One-way ANOVA seguido do pós-teste de Bonferroni, com ${ }^{* *} p<0,01$. Todos os dados expressam a média \pm SEM. $n=5$ animais por grupo.

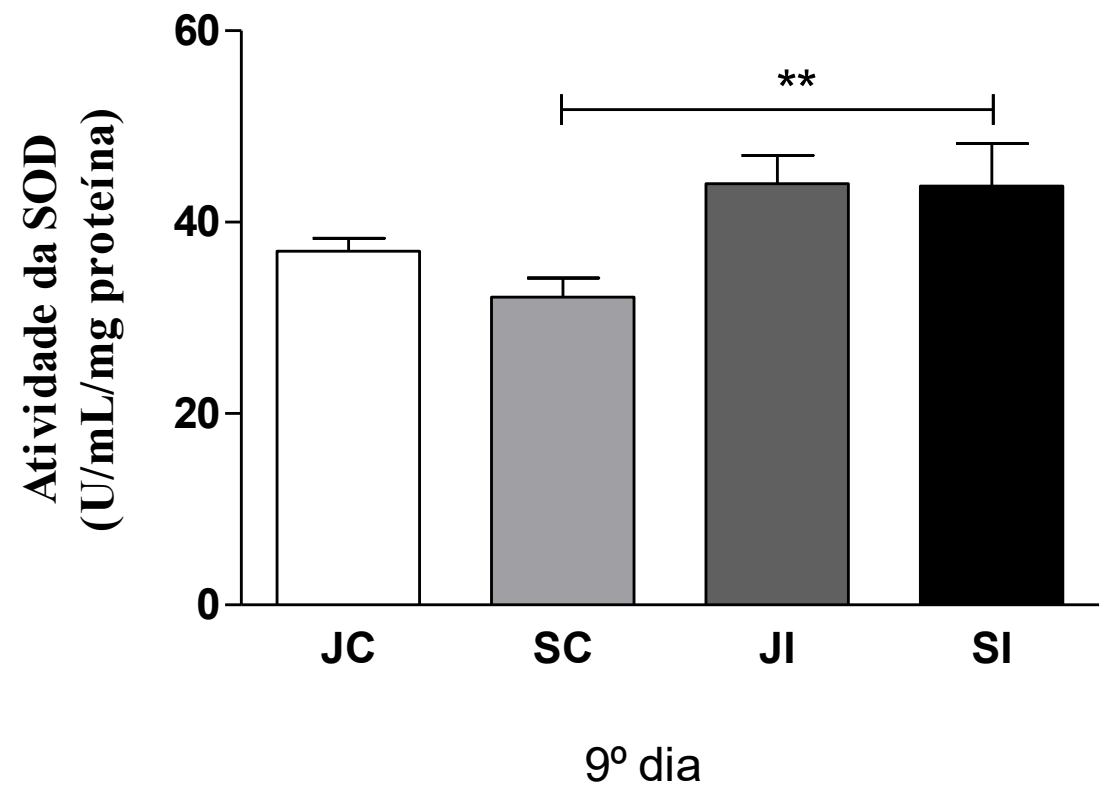




\subsection{Detecção de $\mathrm{O}_{2}^{-}$pelo método de quimioluminescência da lucigenina e avaliação da expressão de NOX2 e SOD2 no timo}

Com o objetivo de avaliar a influência do envelhecimento na geração de ânions superóxidos $\left(\mathrm{O}_{2}^{-}\right)$em animais controles e infectados por $T$. cruzi, foi realizado o registro da quimioluminiscência dependente da lucigenina. Os animais do grupo senil controle apresentaram diminuição significativa da atividade da lucigenina, com consequente diminuição da geração de $\mathrm{O}_{2}^{-}$, em comparação com os animais do grupo jovem controle. Em contrapartida, observamos um aumento significativo de $\mathrm{O}_{2}^{-}$nos animais senis infectados, quando comparados aos jovens infectados. A infecção por si induziu um aumento significativo na geração de $\mathrm{O}_{2}{ }^{-}$em animais senis infectados, quando comparados com os não infectados (figura 29A). No entanto, em animais jovens, a infecção não afetou a geração de $\mathrm{O}_{2}^{-}$no timo.

Adicionalmente, através da análise por Western Blotting, nossos resultados demonstraram que a infecção por $T$. cruzi desencadeou um aumento significativo na expressão da NOX2 no timo de animais jovens e senis, comparados aos seus controles (figura 29B). Não foram encontradas diferenças na expressão de SOD2 em animais senis infectados ou não por $T$. cruzi. No entanto, a expressão de SOD2 foi maior em animais senis, quando comparados aos jovens controles e infectados (figura 29C). 
Figura 29: Geração de $\mathrm{O}^{2-}(\mathrm{A})$ e expressão de NOX2 (B) e SOD2 (C) no timo de ratos Wistar machos jovens e senis não infectados e infectados com $1 \times 10^{5}$ formas tripomastigotas sanguícolas da cepa $Y$ de Trypanosoma cruzi, no $9^{\circ}$ dia após a infecção nos seguintes grupos: Jovem Controle (JC), Senil Controle (SC), Jovem Infectado (JI) e Senil Infectado (SI). One-way ANOVA seguido do pós-teste de Bonferroni, com ${ }^{*} p<0,05,{ }^{* *} p<0,01$ e ${ }^{* *} p<0,001$. Todos os dados expressam a média \pm SEM. $n=5$ animais por grupo.

(A) Geração de O- $^{2-}$

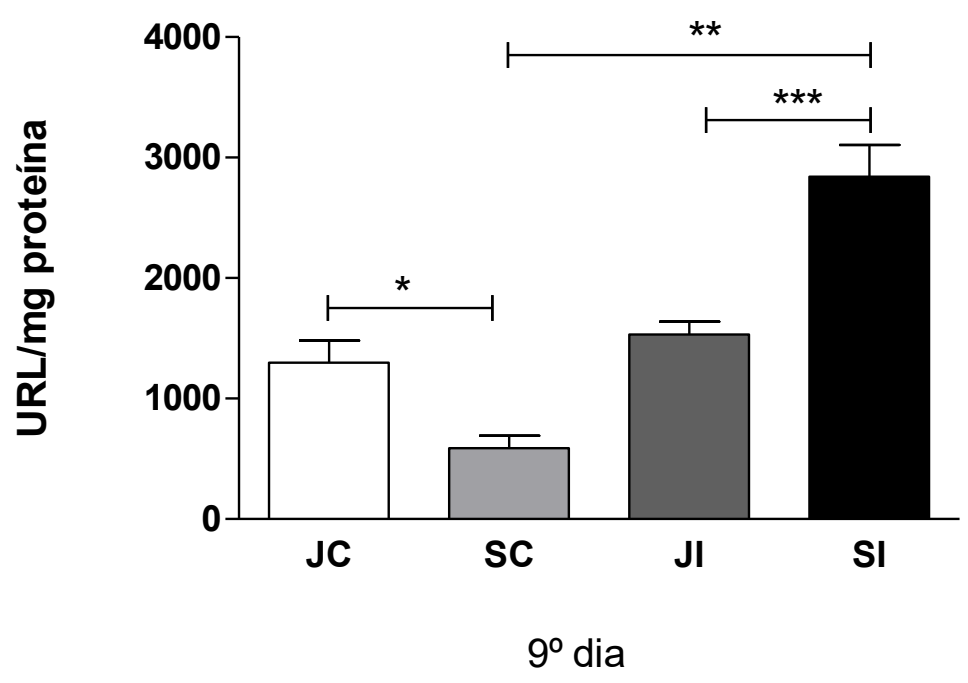

(B) Expressão de NOX2

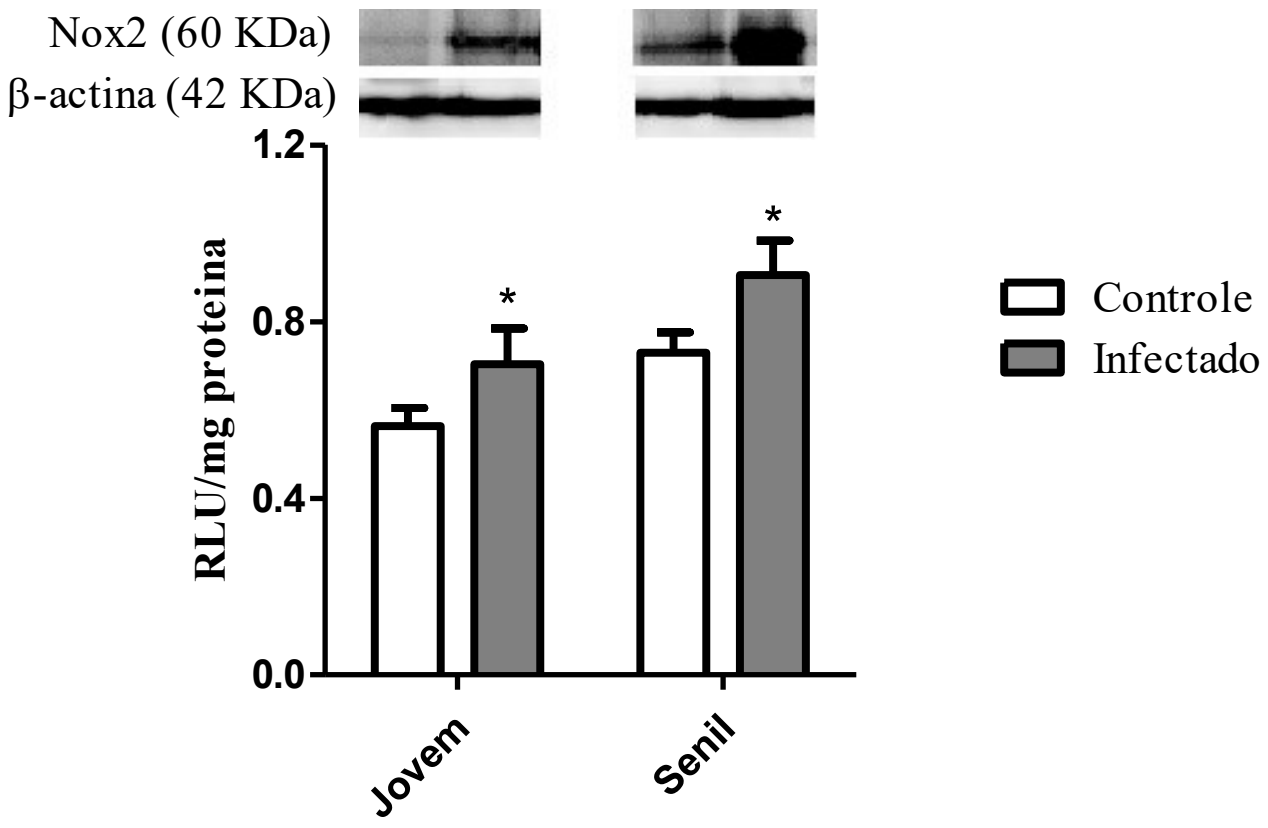


(C)Expressão de SOD2

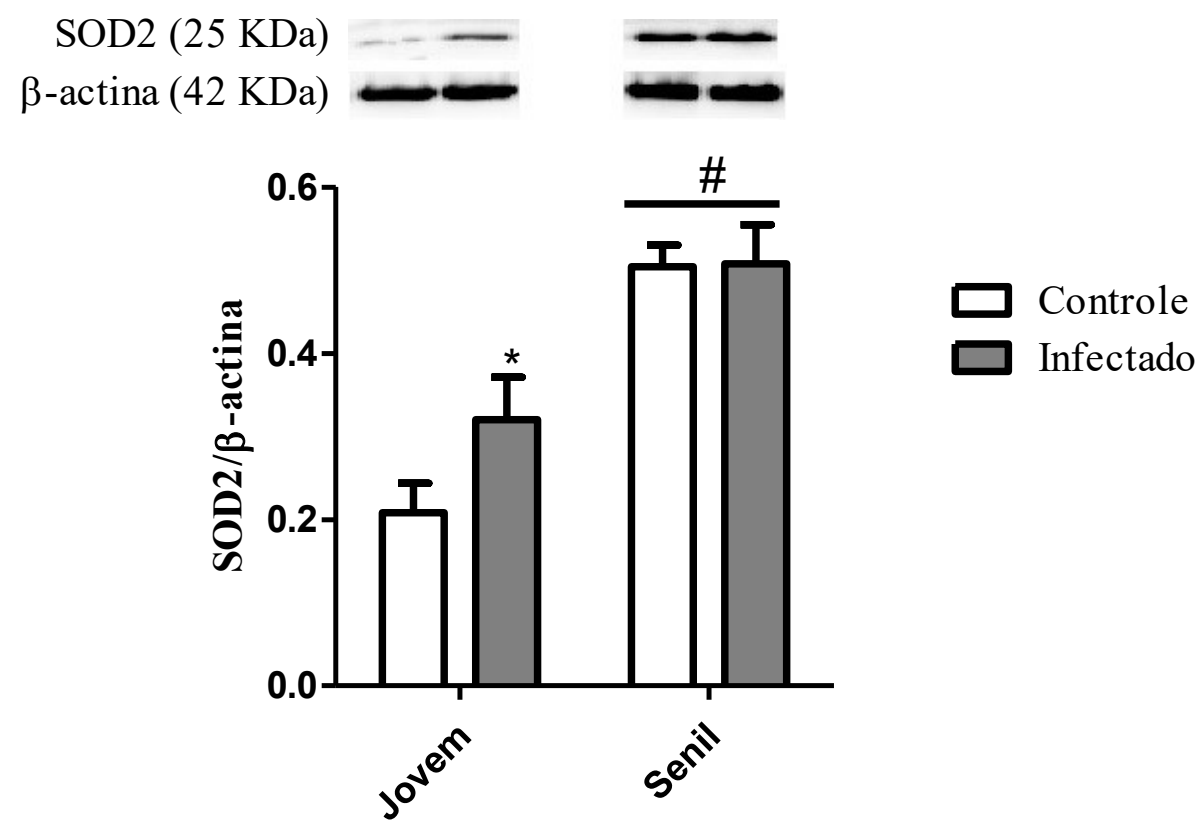




\subsection{Níveis séricos de TGF- $\beta$, IL-2, IL-12, IL-17 e TNF- $\alpha$}

Para determinar se a infecção por $T$. cruzi foi associada às mudanças no perfil de produção de citocinas, os níveis séricos de TGF- $\beta$, IL-2, IL-12, IL-17 e TNF- $\alpha$ foram avaliados em animais jovens e senis. No $16^{\circ}$ dia após a infecção, observou-se um aumento significativo nos níveis de TGF- $\beta$ em animais jovens infectados, quando comparados aos não infectados. Além disso, houve um aumento significativo dos níveis de TGF- $\beta$ em animais senis, infectados ou não, quando comparados aos jovens, tanto no $9^{\circ}$ quanto no $16^{\circ}$ dia após a infecção (figura 30 ).

No $16^{\circ}$ dia após a infecção por T. cruzi, observou-se uma redução significativa de IL-2 no soro de animais senis infectados, quando comparados aos jovens. Por outro lado, não foi observada diferença significativa na quantificação de IL-2 no soro de animais senis e jovens controle, tanto no $9^{\circ}$ quanto no $16^{\circ}$ dia após a infecção (figura 31). Em oposição às análises de II-2, observamos um aumento significativo nas concentrações da importante citocina reguladora IL-12 no $16^{\circ}$ dia de experimento em animais senis infectados em comparação com os jovens infectados. Ainda, foi observado que a infecção por T. cruzi por si desencadeou um aumento significativo nos níveis de IL-12 em animais idosos infectados, quando comparados com os não infectados (figura 32).

A avaliação dos níveis de IL-17, obtidos a partir do soro no $16^{\circ}$ dia após a infecção, demonstrou um aumento nas concentrações desta interleucina nos animais senis infectados e controles, quando comparados aos jovens. No entanto, no $9^{\circ}$ dia após o processo de infecção experimental, apesar de haver uma tendência nos animais controle, não houve diferença significativa na produção de IL-17 (figura 33).

Quanto às alterações na produção de TNF- $\alpha$, podemos observar um aumento significativo nos níveis desta citocina ( $9^{\circ}$ e $16^{\circ}$ dia após a infecção), em animais senis infectados, quando comparado aos senis controles. Não foram observadas diferenças nos níveis de TNF- $\alpha$ entre animais senis controles em coimparação com os animais jovens. Entretanto, no $16^{\circ}$ após a infecção, houve uma redução significativa nos níveis de TNF- $\alpha$ no soro de animais senis infectados, quando comparados aos jovens infectados (figura 34). 
Figura 30: Concentrações de TGF- $\beta$ (pg/mL) determinadas no soro ratos Wistar machos não infectados e infectados com $1 \times 10^{5}$ formas tripomastigotas sanguícolas da cepa $Y$ de Trypanosoma cruzi, no $9^{\circ}$ e $16^{\circ}$ dia após a infecção nos seguintes grupos: Jovem Controle (JC), Senil Controle (SC), Jovem Infectado (JI) e Senil Infectado (SI). One-way ANOVA seguido do pós-teste de Bonferroni, com ${ }^{*} p<0,05,{ }^{* *} p<0,01 e^{* * *} p<0,001$. Todos os dados expressam a média \pm SEM. $n=5$ animais por grupo.

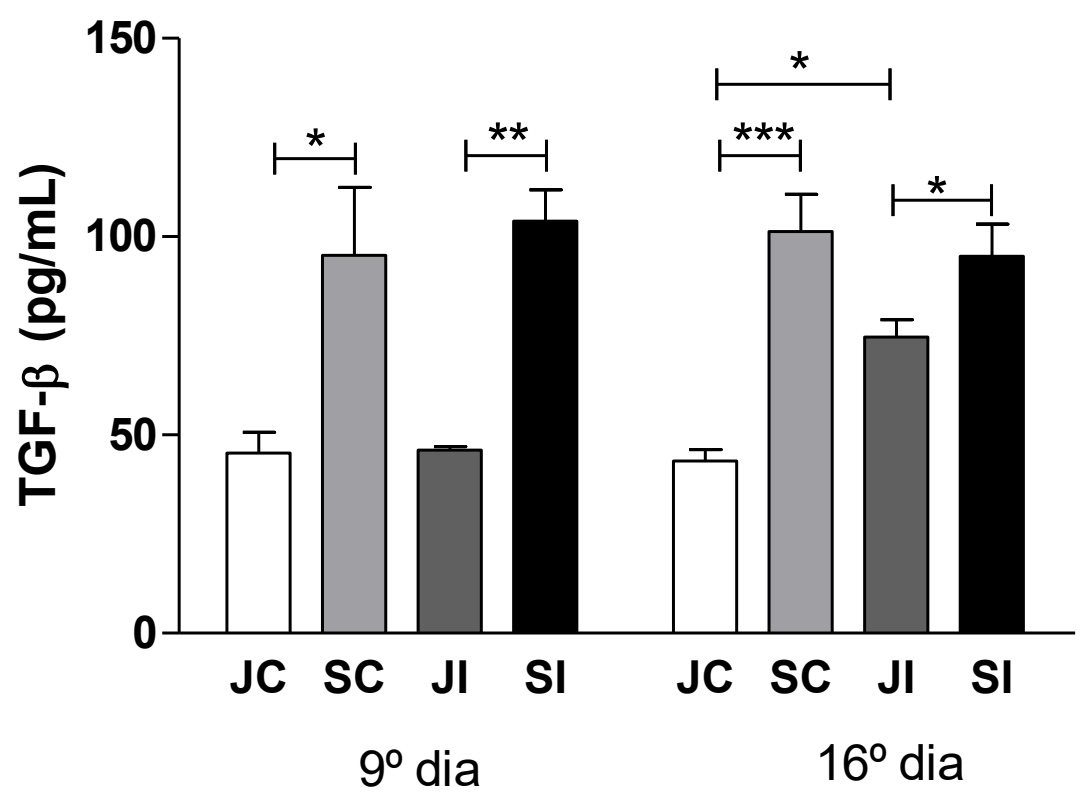


Figura 31: Concentrações de IL-2 (pg/mL) determinadas no soro ratos Wistar machos não infectados e infectados com $1 \times 10^{5}$ formas tripomastigotas sanguícolas da cepa $Y$ de Trypanosoma cruzi, no $9^{\circ}$ e $16^{\circ}$ dia após a infecção nos seguintes grupos: Jovem Controle (JC), Senil Controle (SC), Jovem Infectado (JI) e Senil Infectado (SI). One-way ANOVA seguido do pós-teste de Bonferroni, com ${ }^{*} \mathrm{p}<0,05$. Todos os dados expressam a média \pm SEM. $\mathrm{n}=5$ animais por grupo.

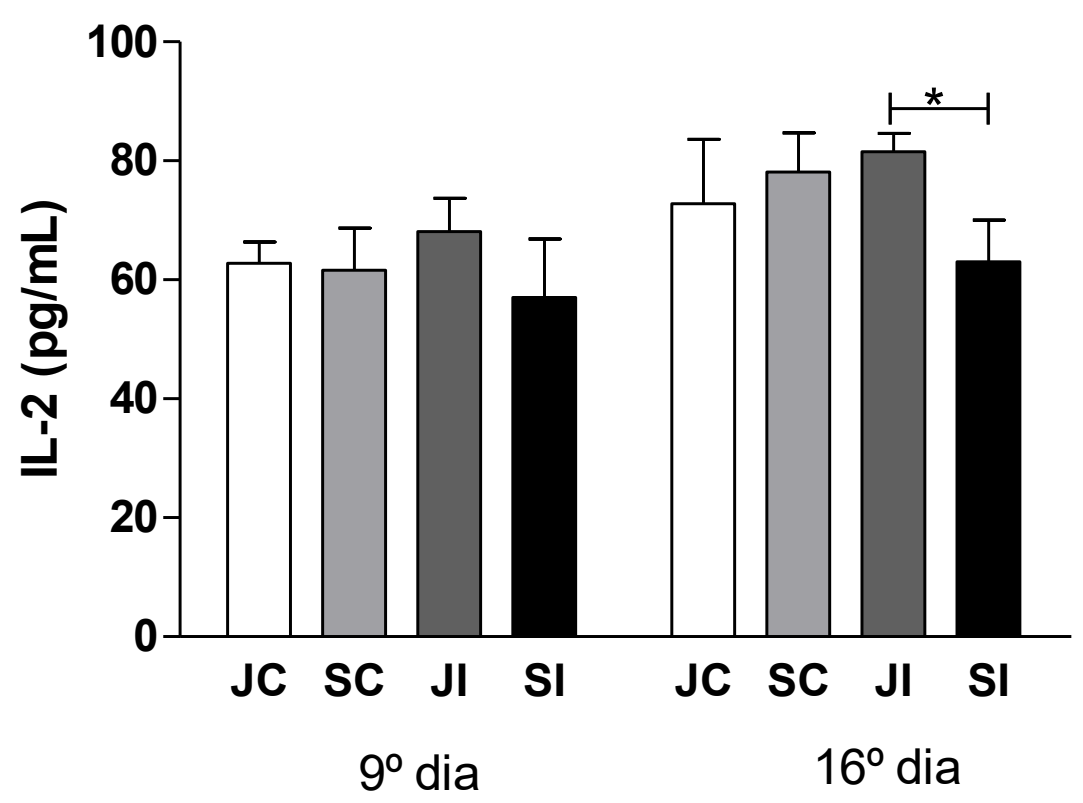


Figura 32: Concentrações de IL-12 (pg/mL) determinadas no soro ratos Wistar machos não infectados e infectados com $1 \times 10^{5}$ formas tripomastigotas sanguícolas da cepa $Y$ de Trypanosoma cruzi, no $9^{\circ}$ e $16^{\circ}$ dia após a infecção nos seguintes grupos: Jovem Controle (JC), Senil Controle (SC), Jovem Infectado (JI) e Senil Infectado (SI). One-way ANOVA seguido do pós-teste de Bonferroni, com ${ }^{*} p<0,05$ e ${ }^{* * *} p<0,001$. Todos os dados expressam a média \pm SEM. $n=5$ animais por grupo.

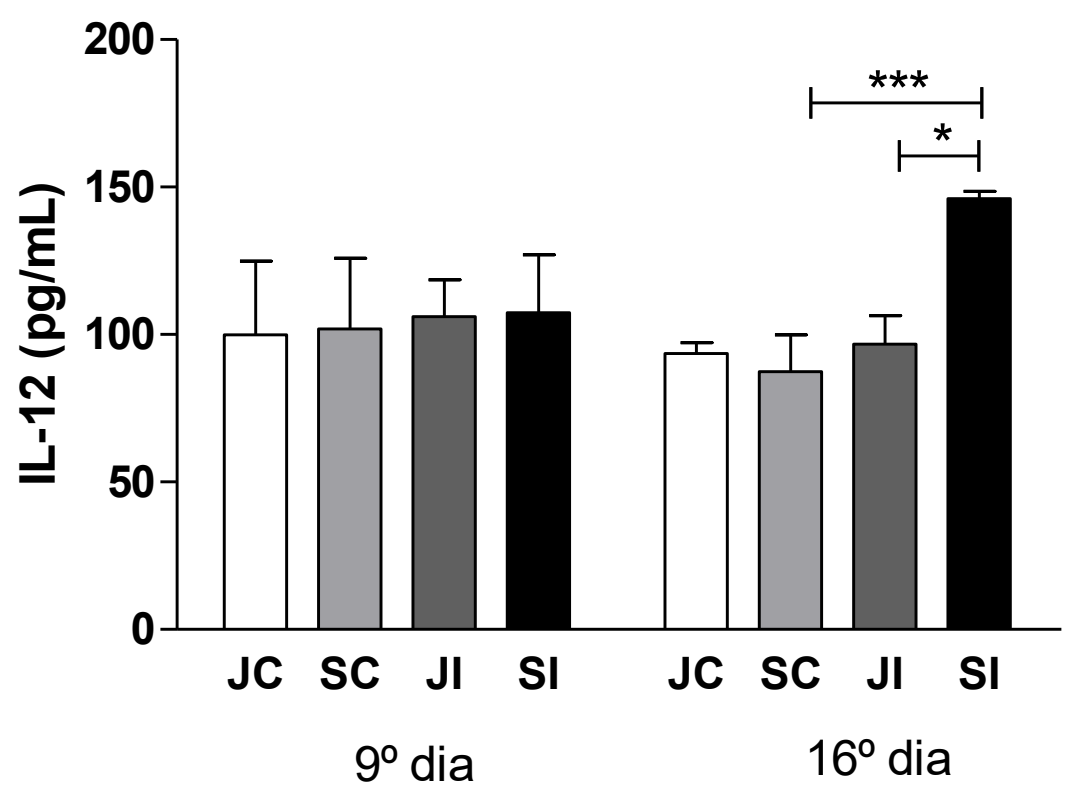


Figura 33: Concentrações de IL-17 (pg/mL) determinadas no soro ratos Wistar machos não infectados e infectados com $1 \times 10^{5}$ formas tripomastigotas sanguícolas da cepa $Y$ de Trypanosoma cruzi, no $9^{\circ}$ e $16^{\circ}$ dia após a infecção nos seguintes grupos: Jovem Controle (JC), Senil Controle (SC), Jovem Infectado (JI) e Senil Infectado (SI). One-way ANOVA seguido do pós-teste de Bonferroni, com ${ }^{*} p<0,05 e^{* * *} p<0,001$.. Todos os dados expressam a média \pm SEM. $n=5$ animais por grupo.

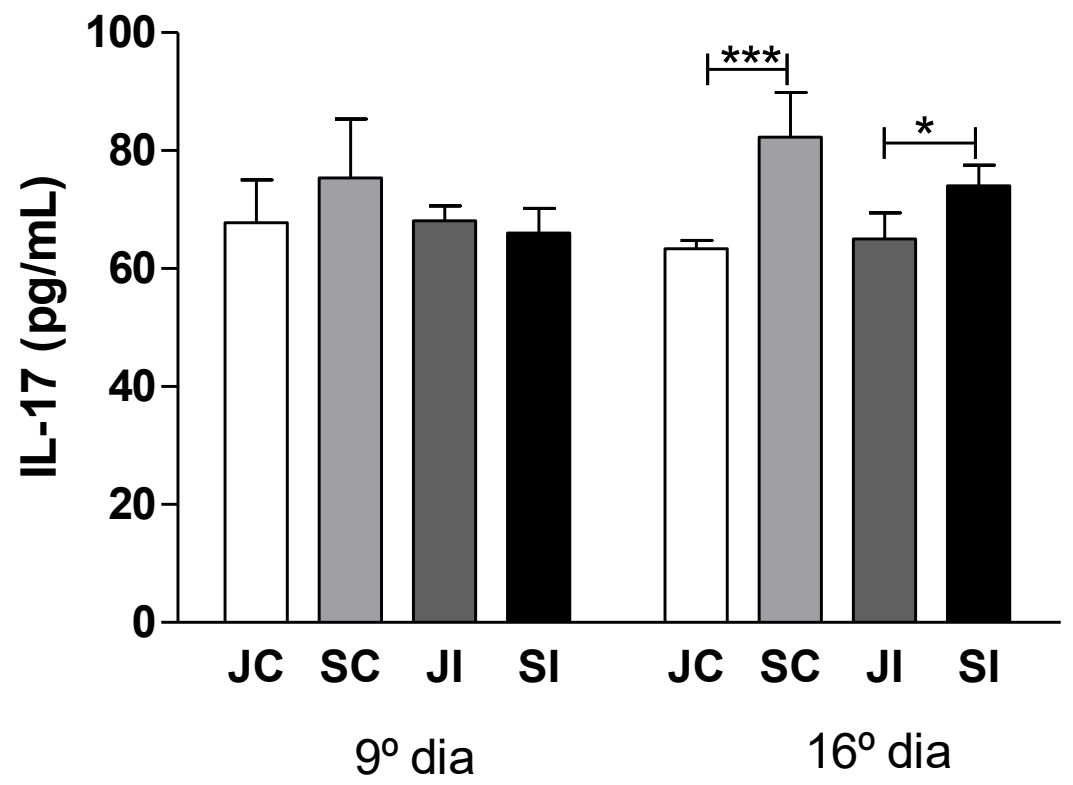


Figura 34: Concentrações de TNF- $\alpha(\mathrm{pg} / \mathrm{mL})$ determinadas no soro ratos Wistar machos não infectados e infectados com $1 \times 10^{5}$ formas tripomastigotas sanguícolas da cepa $Y$ de Trypanosoma cruzi, no $9^{\circ}$ e $16^{\circ}$ dia após a infecção nos seguintes grupos: Jovem Controle (JC), Senil Controle (SC), Jovem Infectado (JI) e Senil Infectado (SI). One-way ANOVA seguido do pós-teste de Bonferroni, com ${ }^{*} p<0,05$ e ${ }^{* *} p<0,01$. Todos os dados expressam a média \pm SEM. $n=5$ animais por grupo.

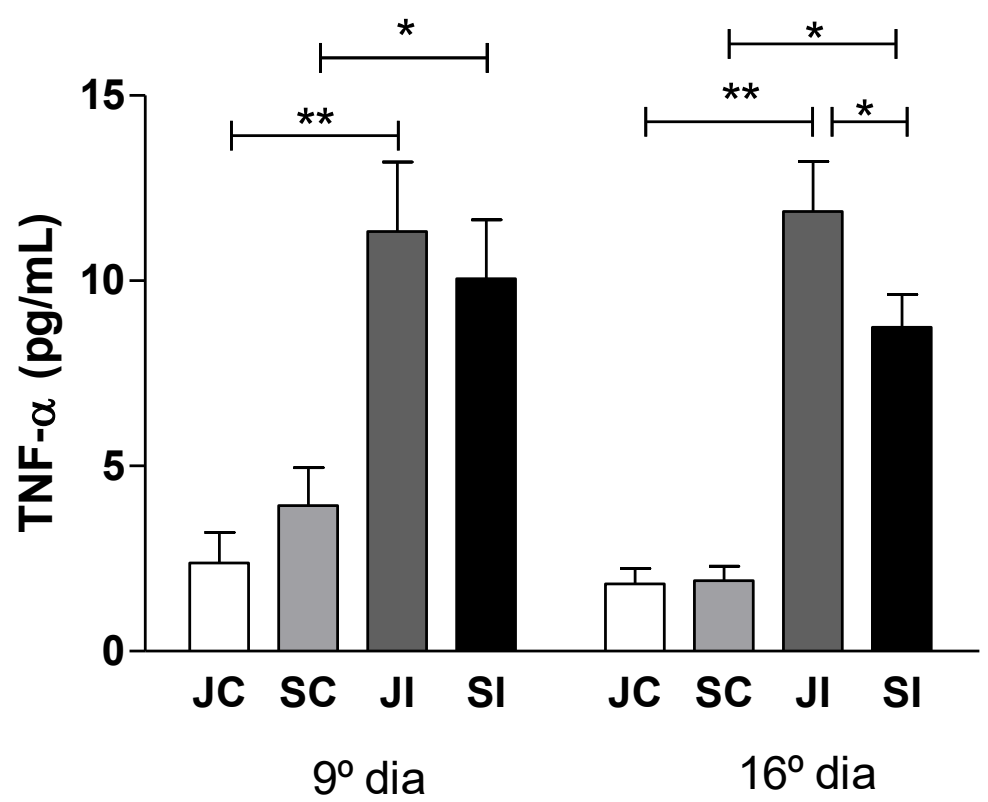


DISCUSSÃO 


\section{DISCUSSÃO}

A imunossenescência é um processo que envolve alterações quantitativas e/ou qualitativas em componentes celulares e moleculares, tanto da resposta imune inata quanto da adaptativa (AW; SILVA; PALMER, 2007). As mudanças que ocorrem no sistema imune inato incluem um decréscimo na quantidade de precursores monocíticos/macrofágicos provenientes da medula óssea, bem como na produção de moléculas de sinalização (SOLANA; PAWELEC; TARAZONA, 2006). Além disso, este processo provoca defeitos nas células hematopoiéticas e prejuízo na migração, maturação e função dos linfócitos periféricos, predispondo à maior suscetibilidade às infecções e autoimunidade (GORONZY; WEYAND, 2003, 2012).

A senescência também está associada a outras alterações que incluem redução na quimiotaxia e síntese de quimiocinas, aumento na produção de ânion superóxido e apoptose. Estudos sugerem que a interferência do processo de apoptose na modulação da resposta imune durante o envelhecimento, pode contribuir para diminuição da capacidade fagocítica de neutrófilos, observada em idosos (CRIGHTON; PUPPIONE, 2006). Adicionalmente, estes mesmos pesquisadores demonstraram que os neutrófilos apresentam também uma reduzida resposta ao fator GM-CSF (fator estimulador de colônias de granulócitos e macrófagos), importante na gênese medular destas células. De forma interessante, uma supressão na população de macrófagos foi evidenciada nos animais senis e infectados por $T$. cruzi, quando comparada aos animais pertencentes ao grupo jovem e infectado (CRIGHTON; PUPPIONE, 2006).

O reconhecimento de peptídeos antigênicos ligados às moléculas do complexo principal de histocompatibilidade ( $\mathrm{MHC}$ ) de classe II na membrana das células apresentadoras de antígenos por linfócitos T é um processo de fundamental importância na orquestração da imunidade celular contra patógenos intracelulares como T. cruzi. De acordo com Montoya-Ortiz (2013), a apresentação de antígenos por moléculas MHC está reduzida em idosos, fato que pode comprometer a interação entre a resposta imune inata e a adaptativa (MONTOYA-ORTIZ, 2013). Confirmando o exposto, Swain e Blomberg (2013) destacaram em seus estudos uma redução na expressão de moléculas do MHC e moléculas coestimulatórias nestes pacientes (SWAIN; BLOMBERG, 2013). Nos nossos experimentos, embora não tenham sido observadas alterações significativas na porcentagem da população de macrófagos ativados de animais senis controles, via molécula MHC II (RT1B), 
obtidos a partir do lavado peritoneal, o processo de envelhecimento ocasionou uma redução acentuada na porcentagem destas moléculas nos animais senis infectados, quando comparados aos animais do grupo jovem infectado.

Estudos demonstram que à medida que envelhecemos ocorrem modificações em outros componentes clássicos da imunidade inata, tais como, células dendríticas, células NK e células NKT, com redução na atividade dessas últimas. Adicionalmente, a resposta de células NK às citocinas se encontra reduzida, resultando em um declínio na citotoxicidade celular, síntese de citocinas e quimiocinas ( $\mathrm{KOCH}$ et al., 2006). As consequências clínicas de tal declínio incluem o aumento na suscetibilidade destes pacientes a processos infecciosos, ocasionados por bactérias, fungos e protozoários bem como redução da eficácia da vacinação quando comparado aos adultos jovens (DAVENPORT; PRICE; MCMICHAEL, 2007; LARBI et al., 2008; WEINBERGER et al., 2008).

Embora os mecanismos envolvidos no envelhecimento ainda não estejam completamente esclarecidos, estudos de Levy e colaboradores (1991), sugerem que a análise funcional da atividade citotóxica de células NK constitui um marcador prognóstico de morbidade e mortalidade no idoso (LEVY et al., 1991). As células NK também são conhecidas por estarem envolvidas na destruição de células infectadas por vírus e células tumorais. Adicionalmente, alguns autores afirmam que o recrutamento de tais células durante a fase inicial da infecção por $T$. cruzi e a sua participação na ativação da resposta imune inata são importantes na defesa do hospedeiro contra a multiplicação do parasita (BRENER; GAZZINELLI, 1997; VITELLI-AVELAR et al., 2006). Durante o início da infecção, antes mesmo da ativação da resposta imune celular adaptativa, as células NK são as principais responsáveis pela síntese de IFN- $\gamma$, citocina que atua sobre os macrófagos, estimulando a produção de IL-12, TNF-a e NO (GAZZINELLI et al., 1992). Em concordância com o descrito, os resultados obtidos em nossos experimentos demonstraram que a senescência provocou uma tendência no declínio na população de células NK, porém não significativa, quando comparado aos animais do grupo jovem não infectado. Entretanto, observamos uma diminuição significativa no percentual de células NKT nos animais senis infectados ou não, quando comparados aos animais jovens.

O IFN- $\mathrm{y}$, produzido por células NK e células $\mathrm{T}$ ativadas, estimula eficientemente a fusão do fagossoma com o lisossoma e a expressão do MHC de 
classe II nos macrófagos, efetivo na contenção da replicação intracelular (tanto in vivo quanto in vitro) do parasita através da indução da biossíntese de NO por macrófagos ativados (ALIBERTI et al., 1996). Durante a fase inicial da infecção aguda por $T$. cruzi, o hospedeiro apresenta uma intensa resposta inflamatória, mediada pela liberação de citocinas, incluindo IL-12, IFN- $\gamma$ e TNF- $\alpha$, mediadores estes, importantes para o controle da replicação parasitária, com a produção de NO e de radicais livres (VESPA; CUNHA; SILVA, 1994). As alterações observadas no decorrer da idade estão associadas com o aumento progressivo das citocinas circulantes e marcadores próinflamatórios, tais como, TNF- $\alpha$ (BRUUNSGAARD et al., 1999; PAOLISSO et al., 1998; ZANNI et al., 2003), IL-12 (PALMERI et al., 2012) e IL-17 (DE ANGULO et al., 2015). Estudos in vitro mostraram uma diminuição na produção de IL-2 por células mononucleares estimuladas de sangue periférico, bem como os linfócitos de indivíduos idosos (CARUSO et al., 2005; PAWELEC et al., 2002). De forma interessante, vários estudos descrevem a associação direta entre a imunossupressão que ocorre durante a infecção por $T$. cruzi e a diminuição da produção de IL-2 e/ou de seu receptor (ROTTENBERG et al., 1989; TARLETON, 2003). Nossos resultados demonstraram uma redução de IL-2, no grupo senil infectado, quando comparado ao grupo jovem infectado, corroborando com os achados anteriores.

IL-12 é uma importante citocina reguladora produzida por células T durante a infecção aguda por $T$. cruzi, envolvida tanto nas respostas imunes inatas quanto adaptativas. Enquanto IL-12 e TNF- $\alpha$ são mediadores essenciais na resistência à infecção aguda, TGF- $\beta$ e IL-10 participam da modulação da reação inflamatória, promovendo a susceptibilidade do hospedeito (SILVA et al., 1998). Estudos demonstraram que o bloqueio na produção de IL-12, através da utilização de um anticorpo monoclonal anti-IL-12 (mAb), resulta em diminuição de infiltrado inflamatório no tecido cardíaco (GALVÃO DA SILVA; JACYSYN; ABRAHAMSOHN, 2003). Por outro lado, IL-12 também pode estar envolvida na modulação do processo de envelhecimento, uma vez que indivíduos idosos apresentam concentrações séricas significativamente aumentadas desta interleucina, quando comparados aos jovens (PALMERI et al., 2012). Em concordância com o descrito previamente, o presente trabalho evidenciou um aumento significativo nos níveis de IL-12 nos animais senis infectados, quando comparados aos jovens infectados. 
Diversos fatores desempenham um papel essencial na regulação da diferenciação e função Th17, de maneira que, a diferenciação celular de Th17 humana requer a participação de TGF- $\beta$, IL-1 $\beta$ e IL-6 (ACOSTA-RODRIGUEZ et al., 2007). De maneira interessante, Huang e colaboradores (2008) demonstraram uma maior produção de IL-17 em células T CD4 ${ }^{+}$, obtidas a partir de esplenócitos de ratos senis, quando comparados aos animais jovens (HUANG et al., 2008). Além disso, Ouyang e colaboradores (2011) observaram que o processo de envelhecimento ocasiona um aumento significativo nos níveis de citocinas Th17, tanto em humanos, quanto em camundongos (OUYANG et al., 2011). Ainda, foi demonstrado que a IL-17A, a principal citocina secretada por células Th17, é produzida durante a infecção por $T$. cruzi, protegendo diretamente as células infectadas através da indução da NADPH oxidase dependente de IL-17A (CAI et al., 2016). Nossos resultados confirmam que o envelhecimento pode modular a produção de IL-17, evidenciando um aumento na produção desta citocina em animais senis controles e infectados, quando comparados aos animais jovens. De forma interessante, as concentrações séricas de TNF- $\alpha$ foram reduzidas em animais senis infectados, quando comparados aos jovens infectados. Embora não tenha sido observada nenhuma diferença na produção de IL-17 no $9^{\circ}$ dia após a infecção, este fato pode correlacionar-se parcialmente com os níveis aumentados de IL-17, sugerindo uma influência negativa desta citocina regulatória nos níveis de TNF-a. Nossos resultados também revelaram que o processo infeccioso desencadeado por T. cruzi ocasionou um aumento da produção de TNF- $\alpha$ observado em animais jovens e senis, comparados aos não infectados.

O TGF- $\beta$ é outra citocina regulatória que possui ação importante em diversos processos biológicos, incluindo o desenvolvimento, manutenção e morte celular, tanto no envelhecimento como em processos patológicos. SEMPOWSKI e colaboradores (2000) demonstraram altos níveis de RNAm de TGF- $\beta$ no timo de idosos. Além disso, estudos indicaram que a inibição fisiológica da sinalização de TGF- $\beta$ pode desacelerar a involução tímica (HAURI-HOHL et al., 2008). Em 2005, Walghabi e colegas descobriram que T. cruzi usa o TGF- $\beta$ da célula hospedeira para manter seu próprio ciclo de vida intracelular (WAGHABI et al., 2005), e tal fato nos levou a avaliar a produção desta citocina. Nossos experimentos são consistentes com os estudos descritos acima, uma vez que se evidenciou um aumento significativo nos níveis de TGF- $\beta$ em animais senis controles e infectados, 
comparados com os jovens, confirmando o aumento desta citocina no processo de envelhecimento. Estes dados nos mostram que com o avanço da idade ocorre uma diminuição na produção de citocinas do padrão Th1, enquanto há um aumento da produção de citocinas do tipo Th2, o que pode contribuir para a maior vulnerabilidade dos idosos a certas infecções (UTSUYAMA et al., 1997). Níveis significativos de TGF- $\beta$ foram mantidos durante o curso da infecção por $T$. cruzi, como observado para animais infectados jovens, quando comparados aos não infectados.

A inibição da linfopoiese B em indivíduos idosos tem sido descrita em vários estádios de desenvolvimento, desde as células hematopoiéticas até os estádios tardios da nova geração de células B. Sugere-se que as alterações da medula óssea que ocorrem a senescência contribuem para as anormalidades na geração dessas células, afetando não apenas a homeostase, mas também as suas funções (CANCRO et al., 2009). Como descrito previamnte, as alterações nos linfócitos B ocasionadas pela a idade incluem a redução de moléculas coestimulatórias, deficiências na sinalização do seu receptor e a diminuição da afinidade de imunoglobulinas (AW; SILVA; PALMER, 2007).

A importância dos linfócitos $B$ no mecanismo de resistência à infecção por $T$. cruzi foi mostrada no trabalho de Cardillo e colaboradores (2007), que ao infectarem animais geneticamente deficientes desse tipo celular, constataram que estes apresentaram maior susceptibilidade à infecção, com diminuição do infiltrado inflamatório e redução do número de linfócitos T de memória (CARDILLO et al., 2007). Estudos de Pascutti e colaboradores (2003) também demonstraram que a resistência de ratos adultos à infecção aguda por $T$. cruzi ocorre em razão da adequada produção de anticorpos. O direcionamento da imunidade humoral é essencial no controle da infecção e a depleção de células B resulta no aumento da parasitemia, tornando os animais infectados menos resistentes à doença (PASCUTTI et al., 2003).

Neste estudo, a caracterização das subpopulações de células $B$, durante a fase aguda da infecção por $T$. cruzi, foi realizada através da marcação da molécula CD45RA. Os resultados confirmaram que o processo de envelhecimento afetou o percentual de linfócitos $B$, uma vez que, os animais senis apresentaram uma redução significativa na expressão de CD45RA, quando comparados aos animais jovens. 
A importância da molécula CD28, para a ativação celular, tem sido descrita em diversas patologias (ELIAS et al., 2005; MATHUR et al., 1999; VILLEGAS et al., 1999). CD28 desempenha um importante papel na diferenciação de células B e produção de anticorpos, além de auxiliar no recrutamento de células para sítios de inflamação através da indução da produção de quimiocinas (BOUR-JORDAN; BLUESTON, 2002). A interação de CD28 com seus ligantes (CD80 e CD86), expressos em células apresentadoras de antígenos, como células dendríticas e macrófagos, é essencial para a completa ativação de células T (YANG; WILSON, 1996).

Sabe-se que a molécula de CD28 é requerida também para a expansão de células T reguladoras (LIU; AMARNATH; CHEN, 2006). Outros pesquisadores já descreveram que camundongos $\mathrm{CD}^{2} 8^{-/-}$apresentavam acentuada redução no número de células Treg $\mathrm{CD} 4^{+} \mathrm{CD} 25^{+}$(TANG et al., 2003). Outros estudos conduzidos por MIYAHIRA et al., (2003), demonstraram a importância da molécula CD28 na resistência à infecção por $T$. cruzi. De acordo com os autores, animais deficientes da molécula CD28 mostraram-se mais susceptíveis à infecção por este parasita, evidenciado pelos altos índices de parasitemia e mortalidade (MIYAHIRA et al., 2003). Estudos de Martins et al., (2004) confirmaram a importância do coreceptor CD28, no estabelecimento de respostas específicas contra $T$. cruzi. Tais autores demonstraram que os animais CD28 ${ }^{-/-}$desenvolveram alta parasitemia sanguínea e tecidual (MARTINS et al., 2004).

Após o nascimento, quase a totalidade das células $T$ expressam a molécula de CD28, decaindo cerca de 40 a $50 \%$ nos linfócitos $\mathrm{CD}^{+}$e de 85 a $90 \%$ nos linfócitos $\mathrm{CD}^{+}$com o avançar da idade (MONTOYA-ORTIZ, 2013). Diante disso, essa perda da expressão deste correceptor estimulatório (CD28), com consequente acúmulo de células T CD8 ${ }^{+} \mathrm{CD} 28^{-}$em idosos constitui um importante marcador biológico de imunossenescência (FRASCA; BLOMBERG, 2011). Ainda, de acordo com Ciubotariu e colegas (1998), as células $\mathrm{T} \mathrm{CD8}^{+} \mathrm{CD} 28^{-}$podem apresentar função supressora da resposta imune, pois a perda da expressão de CD28 poderia favorecer a interação de CTLA-4, que é um homólogo de CD28, com seus ligantes CD80/CD86, regulando negativamente a resposta das células T (CIUBOTARIU et al., 1998). Adicionalmente, a expansão de linfócitos T CD28- também está correlacionada com a reduzida resposta a patógenos e a vacinas observadas na população de idosos (SAURWEIN-TEISSL et al., 2002). Em concordância com o 
exposto, observamos que a senescência por si provocou uma redução significativa de linfócitos T CD4 ${ }^{+} \mathrm{CD} 28^{+}$e $\mathrm{T} \mathrm{CD} 8^{+} \mathrm{CD} 28^{+}$nos animais senis, quando comparada aos animais pertencentes ao grupo jovens (infectados e não infectados).

A interação dos coreceptores estimulatórios (CD80 e CD86), expressos em células apresentadoras de antígenos (como células dendríticas e macrófagos) é essencial para a completa ativação de células T (YANG; WILSON, 1996). De acordo com os pesquisadores, as células dendríticas dos idosos não apresentam aumento na expressão destas moléculas, CD80 e CD86 à sua superfície, sugerindo uma ativação parcial de tais células (MONTOYA-ORTIZ, 2013). Por outro lado, Van Duin et al. (2007) observaram que a maior expressão da molécula coestimuladora CD86 em monócitos de pacientes idosos estava associada com um aumento da resposta à vacinação contra a influenza (VAN DUIN et al., 2007).

No tocante à avaliação da expressão da molécula coestimulatória CD80 em células APC, nossos resultados evidenciaram dois fatos importantes: No $9^{\circ}$ dia após a infecção, os animais senis apresentaram porcentagens não significativas, podendo apenas ser descrito como uma tendência à diminuição presente nos animais senis (infectados ou não). Em seguida, evidenciamos um aumento significativo da expressão dessa molécula em animais senis infectados no $16^{\circ}$ dia após a infecção, quando comparados aos jovens infectados, sugerindo um prolongamento no estímulo do sistema imune desses animais.

A resposta imune adaptativa, comandada por linfócitos $\mathrm{T} \mathrm{CD}^{+}{ }^{+}$que promovem e direcionam os mecanismos de defesa efetores, como produção de interleucinas, ativação de fagócitos, proliferação de linfócitos B e T CD8+ também é essencial para o controle da replicação intracelular do parasita (BRENER; GAZZINELLI, 1997; MINOPRIO et al., 1989). As células T CD8 ${ }^{+}$, quando ativadas, desenvolvem uma atividade citotóxica e específica que resulta na morte das células do hospedeiro que se encontram infectadas por T. cruzi (MARTIN; TARLETON, 2004). Ferraz e colegas (2009) demonstraram que camundongos knockout

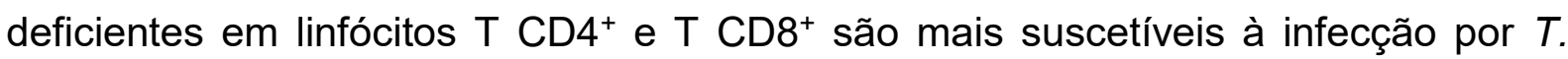
cruzi, apresentando parasitemia elevada e altas taxas de mortalidade.

Uma das principais alterações do sistema imune diante da senescência é a redução do número de células $T$ naive, resultado da progressiva involução tímica e subsequente redução na concentração dos hormônios envolvidos na maturação de células T (DORIA; FRASCA; COVELLI, 1992), bem como da modulação das 
populações leucocitárias. Nesse contexto, a alteração na homeostasia das células T é evento central crítico para as demais modificações observadas na imunidade adquirida em decorrência do envelhecimento. Tal processo ocorre paralelamente às alterações na capacidade de ativação, proliferação e diferenciação das células T naive em células T efetoras (BORASCHI et al., 2013), as quais desempenham funções especializadas, tais como, a secreção de citocinas, reconhecimento e eliminação de patógenos, ativação de macrófagos e células B (SIMPSON, 2011). Isso contribui para uma maior incidência de doenças infecciosas, parasitárias, autoimunes e crônico-degenerativas (SANSONI et al., 2008).

Corroborando com o trabalho acima descrito, evidenciamos em nossos estudos um declínio no percentual de células $\mathrm{TCD}^{+}{ }^{+}$nos animais senis infectados ou não, quando comparados aos animais do grupo jovem infectado e não infectado. Resultado semelhante foi observado nas células T CD8 ${ }^{+} 16$ dias após a infecção, evidenciando que o processo de envelhecimento não prejudicou a resposta imune dos indivíduos infectados.

Outra alteração progressiva que ocorre durante o processo fisiológico de envelhecimento é a alteração funcional do eixo neuroendócrino, com consequente diminuição na produção de hormônios, neurotransmissores e neuropeptídios. Estudos demonstram que a alteração funcional do eixo neuroendócrino, com consequente desequilíbrio na produção de hormônios, neurotransmissores e neuropeptídios, ocorre tanto durante a infecção por T. cruzi, quanto durante o processo fisiológico do envelhecimento, podendo ser diretamente influenciada por fatores imunológicos e endócrinos. Adicionalmente, sabe-se que níveis elevados de corticosterona podem contribuir para o processo de envelhecimento (ZAMBRANO; REYES-CASTRO; NATHANIELSZ, 2015).

Inúmeros trabalhos já demonstraram a relação entre os sistemas endócrino, imune e o eixo hipotálamo hipófise adrenal (HPA), visto que a adrenalectomia ou bloqueio dos receptores de glicocorticóides, com o uso do antagonista RU486, durante a infecção experimental aguda por $T$. cruzi, ocasionou um aumento na produção de citocinas próinflamatórias, e aumento na mortalidade dos animais (PÉREZ et al., 2007; ROGGERO et al., 2006). Resultados também destacam a importante ação imunossupressora dos glicocorticóides na resposta imune específica mediada por células T e B (COUTINHO; CHAPMAN, 2011). Corrêa de Santana et al., (2006) descreveram que, embora não tenham sido observadas 
alterações significativas nos níveis séricos do hormônio adrenocorticotrófico ( $A C T H)$, durante a fase aguda da Doença de Chagas, observou-se um desequilíbrio no eixo HPA, com concentrações aumentadas do hormônio liberador de corticotrofina $(\mathrm{CRH})$, níveis aumentados de corticosterona (CORRÊA-DE-SANTANA et al., 2006), e presença de antígenos de $T$. cruzi na hipófise e adrenal.

Nossos resultados confirmam os trabalhos anteriormente citados, em que a infecção por $T$. cruzi induziu um desequilíbrio no sistema imuno-endócrino, culminando na liberação de concentrações elevadas de corticosterona, observado em animais jovens infectados, quando comparados aos animais não infectados. Além disso, confirmando a influência dos níveis de glicocorticóides no processo de envelhecimento, observou-se um aumento na concentração de corticosterona em animais senis, em comparação com animais jovens não infectados.

Adicionalmente, estudos prévios demonstram que o desequilíbrio na produção de hormônios do eixo HPA durante infecção chagásica, com aumento de glicocorticóides e diminuição de níveis de prolactina compromete o funcionamento do timo, culminando com sua atrofia, resultando em aumento da apoptose de timócitos (LEPLETIER et al., 2012). Em contrapartida, estudos de Roggero e colaboradores (2006), observaram que a atrofia tímica pode ser parcialmente prevenida através do bloqueio de receptores para glicocorticóides (ROGGERO et al., 2006). Além disso, de acordo com estudos de Migliorati e colegas (1994), a administração de doses farmacológicas de glicocorticóides é capaz de induzir a apoptose de timócitos murinos imaturos, células NK e linfócitos $T$ citotóxicos (MIGLIORATI et al., 1994).

Embora os mecanismos envolvidos na patogênese da cardiopatia chagásica ainda não estejam completamente esclarecidos, estudos sugerem a interferência do processo de apoptose na modulação da resposta imune durante a infecção por $T$. cruzi, contribuindo para a persistência do parasita na fase crônica da doença de Chagas. Neste contexto, estudos de Tostes et al., (2005) demonstraram que a apoptose de cardiomiócitos e células inflamatórias no tecido cardíaco de pacientes chagásicos, está associada com a progressão da falência cardíaca observada nestes pacientes (TOSTES et al., 2005).

Lopes e colaboradores (1995) relataram a importância do processo de morte induzida de linfócitos $\mathrm{T}$, principalmente $\mathrm{CD}^{+}$, durante a infecção causada por $T$. cruzi e sugeriram que a apoptose de células $\mathrm{T}$ maduras seria uma característica 
marcante da doença, com participação na imunossupressão e persistência do parasita no hospedeiro. Este estudo demonstrou que células T provenientes do baço de animais infectados apresentaram viabilidade reduzida, após estimulação in vitro e que, embora ocorram por mecanismos diferentes, tanto os linfócitos T CD4 ${ }^{+}$, quanto T CD8 ${ }^{+}$, sofrem apoptose durante a infecção experimental (LOPES et al., 1995). Outros experimentos também demonstraram o papel da apoptose na patogenia da doença de Chagas experimental e inclusive afirmaram que o bloqueio deste processo seria uma intervenção com grande potencial terapêutico (DOSREIS et al., 2005; FREIRE-DE-LIMA et al., 2000; MONTALVÃO et al., 2010; NUNES et al., 1998). Além do baço, a morte celular por apoptose também ocorre em outros locais, como linfonodos e coração (DE MEIS et al., 2006; ZHANG et al., 1999).

Com o envelhecimento, algumas funções dos neutrófilos, como quimiotaxia, produção de ânion superóxido e processo de apoptose também estão alteradas. A morte celular prematura de neutrófilos pode contribuir para a reduzida atividade fagocitária observada no idoso (CRIGHTON; PUPPIONE, 2006). Desta forma, nossos experimentos condizem com os trabalhos citados acima, visto que, os timócitos dos animais pertencentes ao grupo senil (com ou sem infecção) apresentaram elevados percentuais de apoptose (estágio inicial ou tardio) e reduzidos índices de viabilidade celular, quando comparados aos animais dos grupos jovens.

A atrofia tímica, presente na fase aguda da doença de Chagas, é caracterizada, principalmente, pela intensa depleção de timócitos corticais imaturos, estando diretamente relacionada com altos níveis plasmáticos de glicocorticóides. De acordo com estudos em humanos, embora ocorra um declínio gradual dos timócitos ao longo da vida, essa redução nos espaços epiteliais tímicos é evidenciada já no primeiro ano de vida do indivíduo, atingindo o nível de $75 \%$ de redução na meia-idade (STEINMANN; KLAUS; MÜLLER-HERMELINK, 1985). Além da perda de timócitos e massa linfocitária, as alterações que ocorrem com o processo de envelhecimento, incluem mudanças na arquitetura e tamanho do órgão (PALMER, 2013), com deposição de quantidades crescentes de tecido adiposo no parênquima do timo (DIXIT, 2010), contribuindo para uma maior incidência de doenças infecciosas, parasitárias, autoimunes e crônico-degenerativas (SANSONI et al., 2008). De acordo com o descrito, observamos no presente estudo, que os animais senis (com ou sem infecção) apresentaram uma redução acentuada no 
peso do timo, bem como no número de timócitos, quando comparados aos animais jovens.

Além da involução do timo, a alteração no processo de diferenciação de timócitos é um fator importante que pode também estar envolvido com as disfunções do sistema imune relacionadas com a idade. Estudos destacam que o processo de envelhecimento é acompanhado por um bloqueio idade-dependente nos precursores de linfócitos $T$, afetando principalmente os timócitos imaturos duplo-negativos (DN) (PHILLIPS et al., 2004; THOMAN, 1995), ou seja, regula negativamente a transição DN1-DN2, promovendo um aumento na proporção das subpopulações de timócitos DN1, com consequente redução nas subpopulações de timócitos DN2 e DN3 (HENG et al., 2005). De forma interessante, foi relatada por alguns autores que a expressão de CD3, dentro do compartimento de células DN, aumenta com a idade. Tais alterações neste importante órgão linfóide podem afetar diretamente a geração de timócitos duplo positivos (DP), induzindo alterações nas fases seguintes da timopoise, bem como na exportação de células T para a periferia do sistema imune.

Corroborando com os estudos previamente citados, demonstramos em nossos experimentos que os animais senis, infectados ou não, apresentaram um aumento nas subpopulções de timócitos DN1, que foi associado a uma importante redução nas subpopulações de timócitos DN3, DN4 e DP, quando comparado aos animais pertencentes aos grupos jovens. Adicionalmente, uma significante expansão de timócitos $C D 3^{+} D N$ foi observada nos animais senis, em comparação aos animais jovens não infectados, demonstrando que a infecção resulta na alteração da população de timócitos DN.

Pesquisas demonstraram que o envelhecimento também está associado com as reações deletérias que ocorrem continuamente nas células e nos tecidos provocadas pelo aumento dos radicais livres, e estes contribuiem para a progressão da senescência (HARMAN, 1981). As EROs podem ativar as vias de sinalização inflamatória intracelular, promovendo a migração de células inflamatórias através da barreira endotelial, levando à liberação de mediadores inflamatórios em vários tecidos (MARTINON, 2010), incluindo citocinas produzidas pela ativação de fatores de transcrição regulados por redox, como fator Nuclear kappa B (NF-kB) (CRISTOFANON et al., 2009; KIM et al., 2008).

Além disso, as EROs estão envolvidas aos danos associados a idade e a macromoléculas, tais como, proteínas, lípidos e ácidos nucleicos, levando à 
peroxidação lipídica e mutações no DNA (MAMELAK, 2007; VALKO et al., 2007), resultando em estresse e desencadeamento de diversas doenças. Outros investigadores também demonstraram que as células senescentes podem ativar a produção exacerbada das EROs (CHEN et al., 1995).

Um dos biomarcadores mais importantes do estresse oxidativo é a 8isoprostano que é formado por uma reação não-enzimática, levando à oxidação do ácido araquidônico a partir de membranas fosfolipídicas (MORROW; ROBERTS, 1996). Durante a doença de Chagas há um aumento na atividade da fosfolipase $A 2$, resultando em uma síntese aumentada do ácido araquidônico (SHARMA et al., 2013, 2014). A infecção por T. cruzi induz o aumento da produção de EROs (MACHADO-SILVA et al., 2016), que pode reagir com o ácido araquidônico excessivo, levando à formação de 8-isoprostano. De acordo com Syslová et al., (2014), nossos resultados demonstram níveis elevados de 8-isoprostano em animais senis controles, quando comparados aos jovens controles, mas não foram encontradas diferenças significativas entre ratos senis infectados e não infectados (SYSLOVÁ et al., 2014).

Ainda, Kawamoto et al., (2013) mostraram que a idade parece influenciar na produção de TBARS, outro biomarcador de peroxidação lipídica, bem como na atividade da óxido nítrico sintase (NOS), aumentando ainda mais as concentrações de óxido nítrico (NO) (KAWAMOTO et al., 2013). Porém deve-se ressaltar que a dosagem de TBARS não é considerada um teste sensível para avaliação de EROs. Nossos resultados mostraram que os animais senis e infectados apresentaram níveis de TBARS significativamente aumentados, quando comparados aos seus controles, bem como ao grupo jovens controle e infectado. Em relação aos níveis de NO, avaliados no lavado peritoneal, observamos concentrações significativamente elevadas nos animais jovens infectados, quando comparados aos seus controles, bem como ao grupo senil, infectado ou não. Adicionalmente, encontramos concentrações aumentadas de NO no soro de animais senis controle e infectados, quando comparados ao grupo jovem infectados ou não, sugerindo que o envelhecimento promove aumento de EROs a partir do NO, e estas podem contribuir com o desencadeamento de lesões celulares. Entretanto, parece não estar envolvido com a resposta direta contra o parasita, uma vez que não foram encontradas diferenças significativas entre animais idosos infectados e não infectados. 
Alguns estudos mostraram que a peroxidação lipídica está intimamente associada à senescência celular, e uma vez prevenida, pode ocorrer um aumento da vida útil das células, atrasando o processo de senescência. Dessa maneira, o presente estudo propôs a avaliação da maquinaria antioxidante. Inicialmente, a atividade plasmática da enzima SOD foi analisada. Existem três isoformas de SOD, incluindo SOD1 que se encontra no citoplasma e espaço intermembranar mitocondrial, SOD2 localizado na matriz mitocondrial e SOD3 que é uma enzima extracelular. Todas as três isoformas têm a função de catalisar a dismutação do ânion superóxido em oxigênio e peróxido de hidrogênio, atuando como um fator antioxidante (LI; HORKE; FÖRSTERMANN, 2013). Nossos resultados demonstraram uma atividade significativamente reduzida da SOD, relacionada à idade, em animais infectados e não infectados, em comparação com os jovens, corroborando com os achados anteriores (DE LA FUENTE et al., 2004; MLADENOV et al., 2015).

A glutationa peroxidase é outro antioxidante enzimático, responsável pela redução de peróxido de hidrogênio em água e hidroperóxidos lipídicos, usando GSH como um substrato. Com base nisso, o presente trabalho demonstrou que a senescência provocou um aumento significativo de GSH, quando comparada ao grupo jovem controle, bem como os animais jovens infectados, quando comparados aos seus controles. Para os animais idosos, a infecção não desencadeou diferenças estatísticas entre infectados e não infectados, concordando com os dados de Mladenov e colaboradores (MLADENOV et al., 2015). Neste contexto, observamos uma atividade antioxidante reduzida, suportada pelos presentes dados experimentais, uma vez que foram encontradas concentrações aumentadas de 8isoprostano, nitrito e níveis de TBARS em animais senis, comparados aos animais jovens.

Estudos mostram que a NADPH oxidase-2 (NOX2) pode desempenhar um importante papel na produção de radicais livres no envelhecimento, devido sua expressão aumentada em diferentes tecidos de animais mais velhos (LEE et al., 2015; ZUO et al., 2011; SALLES et al., 2005). Além disso, outros estudos revelam um aumento na expressão da NOX2 na presença de um estímulo inflamatório ou frente a fatores de risco cardiovasculares (BRANDES; SCHRÖDER, 2008). Confirmando esses achados, nossos resultados apontam um aumento da expressão de NOX2 no timo de animais jovens e senis na fase aguda da doença de Chagas 
experimental, quando comparados aos jovens e senis não infectados. No entanto, apenas os animais do grupo senil infectado apresentaram maior geração de ânion superóxido.

Como descrito anteriormente, a SOD é um importante regulador celular de radicais livres, atuando como antioxidante, catalisando a dismutação de ânion superôxido em $\mathrm{O}_{2}$ e $\mathrm{H}_{2} \mathrm{O}_{2}$. Bolzan et al., (1995) demonstraram que animais idosos apresentam uma maior atividade de SOD no timo, sendo a expressão de SOD2 regulada por citocinas (BOLZÁN et al., 1995; DOUGALL; NICK, 1991; VISNER et al., 1990). Nossos resultados mostram um aumento da expressão protéica de SOD2 em animais jovens infectados com $T$. cruzi, quando comparados aos jovens controles e nos animais do grupo senil, infectados ou não, quando comparados aos jovens. A maior expressão de SOD2 deve estar associada à maior geração de ânion superôxido nos animais infectados, contudo, essa maior expressão enzimática não foi suficiente para reduzir os níveis de ânion superôxido nos animais senis infectados.

Outra abordagem que consideramos pertinente para 0 estudo dos mecanismos imunológicos operantes durante a infecção por $T$. cruzi é a caracterização das células $T$ reguladoras (Treg). Todavia, tem sido descrito que as células Treg podem ser identificadas como estáveis $\mathrm{CD}^{+}{ }^{+} \mathrm{CD} 25^{\text {high }} \mathrm{FOXP} 3^{+}$e instáveis $\mathrm{CD}^{+}{ }^{+} \mathrm{CD} 25^{\text {low }} \mathrm{FOXP3^{+ }}$, ou seja, estas últimas são células que apresentam baixa expressão de CD25 e expressam o fator de transcrição FOXP3 transitoriamente (KOMATSU et al., 2009; MIYAO et al., 2012). Embora poucos estudos abordem este contexto, Komatsu e colaboradores (2009) demonstraram que em pacientes com artrite reumatóide, o grau de severidade está associado à maior proporção de células Treg $\mathrm{CD}^{+} \mathrm{CD} 25^{\text {lowFOXP3 }}{ }^{+}$. Sabe-se que durante 0 envelhecimento ocorre uma mudança no perfil de células $\mathrm{T}$ reguladoras, com um predomínio de $\mathrm{CD}^{+}{ }^{+} \mathrm{CD} 25^{\text {lowFOXP3 }}{ }^{+}$. Em concordância com o exposto, o presente trabalho confirmou o descrito, visto que os animais senis controles, apresentaram um aumento na população de células $\mathrm{CD} 4^{+} \mathrm{CD} 25^{\text {lowF }} \mathrm{OXP} 3^{+}$quando comparado aos animais jovens sem infecção.

Tem sido demonstrado o envolvimento de células $T$ reguladoras na resposta imune durante infecções causadas por vírus, bactérias, fungos e protozoários (MILLS, 2004). A ação das células Treg pode traduzir-se em efeitos deletérios ou protetores ao hospedeiro, visto que a atividade supressora dessas células pode 
limitar respostas imunes efetoras desreguladas, ou exacerbadas, prevenindo o desenvolvimento de danos teciduais. Por outro lado, a capacidade imunossupressora destas células pode propiciar a persistência do patógeno (MILLS, 2004).

Estudos conduzidos por De Araújo e colaboradores (2012) ressaltaram a alta expressão de FOXP3 em células $\mathrm{TCD} 4^{+} \mathrm{CD} 25^{\text {high }}$ de pacientes com a forma clínica indeterminada da doença de Chagas (DE ARAÚJO et al., 2012). Neste contexto, estudos de Da Silveira et al., (2009) também evidenciaram a maior expressão de FOXP3 em pacientes chagásicos que não apresentavam complicações digestivas quando comparado a pacientes com mega cólon (DA SILVEIRA et al., 2009).

Estudos de Vitelli-Avelar et al., (2005) relataram a importância das subpopulações de linfócitos $\mathrm{T} \mathrm{CD}^{+} \mathrm{CD} 25^{+}$nos mecanismos imunorregulatórios durante a infecção por $T$. cruzi. Os autores demonstraram um aumento na frequência de células $\mathrm{CD}^{+}{ }^{+} \mathrm{CD} 25^{\text {high }} \mathrm{FOXP3}^{+}$e NKT $\left(\mathrm{CD} 3^{+} \mathrm{CD} 16^{-} \mathrm{CD}^{-} 6^{+}\right)$, em pacientes portadores da forma clínica indeterminada. Tais autores sugeriram que a ausência falta de populações regulatórias em indivíduos sintomáticos poderia levar à exacerbação das atividades citotóxicas, culminando em dano tecidual, observado em pacientes com forma clínica cardíaca da doença de Chagas (VITELLI-AVELAR et al., 2005). Observamos em nossos experimentos que, durante a fase aguda da infecção por $T$. cruzi ( $9^{\circ}$ dia), os animais senis, infectados ou não, apresentaram uma diminuição no percentual de células $T$ reguladoras $C D 4^{+} C D 25^{\text {high }} F O X P 3^{+}$. Por outro lado, não foram observadas alterações significativas nas populações de células $\mathrm{CD}^{+} \mathrm{CD} 25^{\text {lowFOXP3 }}{ }^{+}$entre os animais jovens e senis infectados.

É importante ressaltar, que a molécula CD25 é também expressa por células ativadas, tais como, linfócitos $\mathrm{T}$, células $\mathrm{B}$ e macrófagos/monócitos. Estudos descrevem que o envelhecimento é acompanhado por alterações na expressão de CD25, com aumento no percentual de linfócitos TCD4 ${ }^{+}$CD25-, porém nos nossos experimentos não foram observadas diferenças significativas em tais células entre os grupos em estudo. Em contrapartida, observamos uma diminuição no percentual de células TCD4 $4^{+} \mathrm{CD} 25^{\text {high }}$ em animais senis infectados, quando comparado aos animais jovens infectados.

A senescência desencadeou alterações no compartimento tímico, afetando etapas essenciais no desenvolvimento dos timócitos e exportação de células $T$ para a periferia, com consequentes implicações diretas na competência imunológica do 
organismo. Os resultados deste trabalho são de grande importância na elaboração de futuras intervenções imununoterapêuticas que visem proporcionar ao hospedeiro um direcionamento eficiente da resposta imune durante a infecção. Portanto, estratégias que proporcionem a promoção da longevidade e o envelhecimento saudável são fundamentais diante do progressivo envelhecimento populacional e nítida inversão da pirâmide etária. 
CONCLUSÃO 


\section{CONCLUSÃO}

Com o presente estudo, conseguimos avançar na compreensão dos mecanismos celulares e moleculares envolvidos nas modificações da imunidade ao longo da vida e seus reflexos frente à doença de Chagas. Inúmeras alterações foram observadas, incluindo resposta imune ineficiente, aumento do estresse oxidativo, bem como diminuição da atividade de enzimas antioxidantes e comprometimento no processo de maturação celular intratímica, os quais afetam etapas essenciais no desenvolvimento dos timócitos e exportação de células $T$ para a periferia. Adicionalmente, foi evidenciado um desequilíbrio funcional do eixo neuroendócrino, com consequente aumento na produção de corticosterona e diminuição da viabilidade celular. Além disso, foram observadas mudanças no perfil da produção de citocinas, como TGF- $\beta$, IL-2, IL-12, IL-17 e TNF- $\alpha$, que promoveram implicações diretas na competência imunológica do organismo.

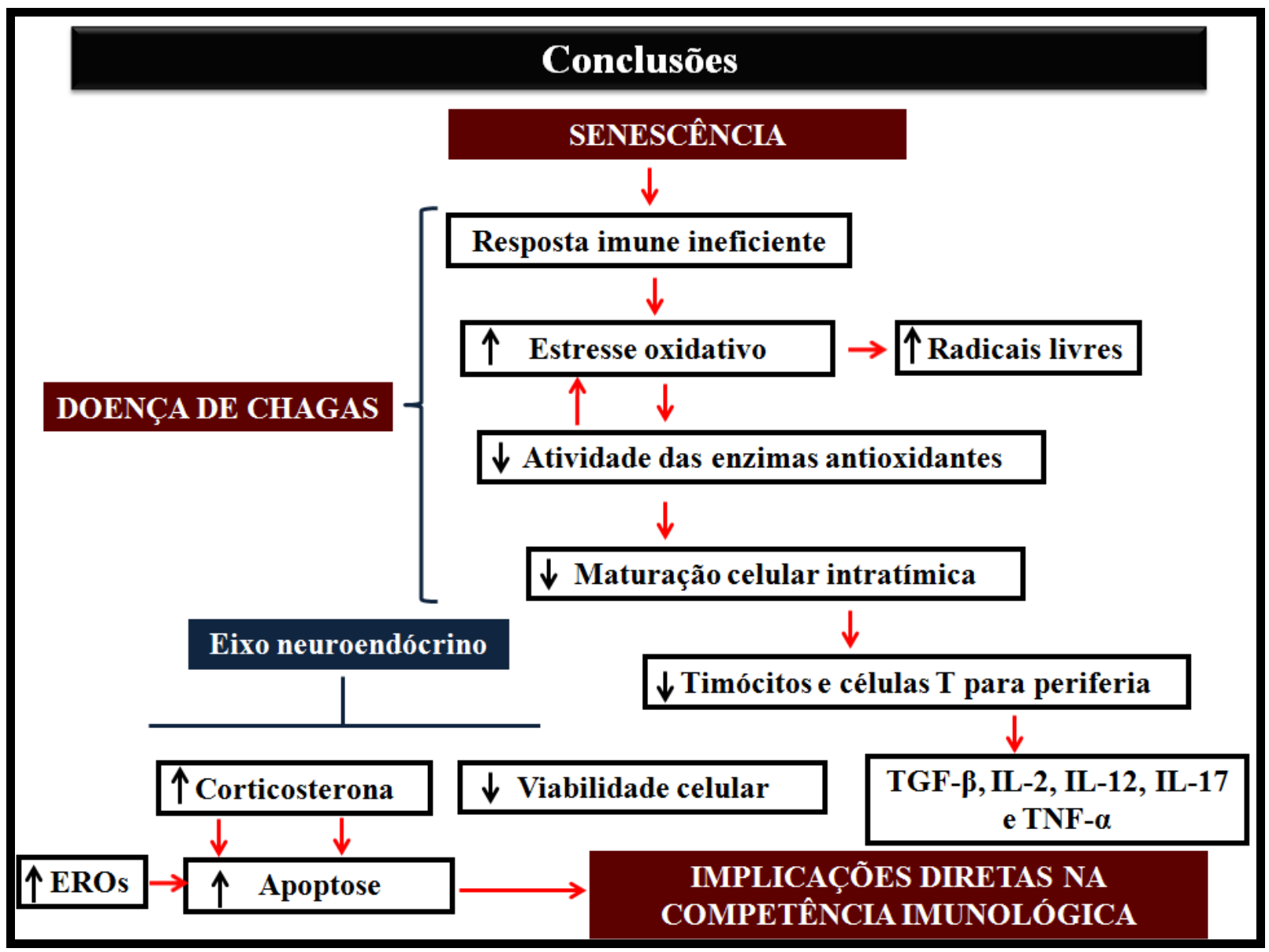


REFERÊNCIAS BIBLIOGRÁFICAS 


\section{REFERÊNCIAS BIBLIOGRÁFICAS}

ACOSTA-RODRIGUEZ, E. V. et al. Interleukins 1 beta and 6 but not transforming growth factor-beta are essential for the differentiation of interleukin 17-producing human T helper cells. Nature Immunology, v. 8, n. 9, p. 942-949, set. 2007.

AGOSTINHO, P. Perspectiva psicossomática do envelhecimento. Revista Portuguesa de Psicossomática, v. 6, n. 1, 2004.

ALIBERTI, J. C. et al. Interleukin-12 mediates resistance to Trypanosoma cruzi in mice and is produced by murine macrophages in response to live trypomastigotes. Infection and Immunity, v. 64, n. 6, p. 1961-1967, jun. 1996.

AW, D.; SILVA, A. B.; PALMER, D. B. Immunosenescence: emerging challenges for an ageing population. Immunology, v. 120, n. 4, p. 435-446, 1 abr. 2007.

BAECHER-ALLAN, C. et al. CD4+CD25high regulatory cells in human peripheral blood. Journal of Immunology (Baltimore, Md.: 1950), v. 167, n. 3, p. 1245-1253, 1 ago. 2001.

BECKMAN, J. S.; KOPPENOL, W. H. Nitric oxide, superoxide, and peroxynitrite: the good, the bad, and ugly. The American Journal of Physiology, v. 271, n. 5 Pt 1, p. C1424-1437, nov. 1996.

BECKMAN, K. B.; AMES, B. N. The free radical theory of aging matures. Physiological Reviews, v. 78, n. 2, p. 547-581, abr. 1998.

BERN, C. Chagas' Disease. The New England Journal of Medicine, v. 373, n. 5, p. 456-466, 30 jul. 2015.

BOLZÁN, A. D. et al. Hormonal modulation of antioxidant enzyme activities in young and old rats. Experimental Gerontology, v. 30, n. 2, p. 169-175, abr. 1995.

BORASCHI, D. et al. The gracefully aging immune system. Science Translational Medicine, v. 5, n. 185, p. 185ps8, 15 maio 2013.

BORGES, C. R. B. et al. Papel do óxido nítrico no desenvolvimento de lesões cardíacas na fase aguda da infecção experimental pelo Trypanosoma cruzi. Revista da Sociedade Brasileira de Medicina Tropical, v. 42, n. 2, p. 170-174, abr. 2009.

BOUR-JORDAN, H.; BLUESTON, J. A. CD28 function: a balance of costimulatory and regulatory signals. Journal of Clinical Immunology, v. 22, n. 1, p. 1-7, jan. 2002.

BRANDES, R. P.; SCHRÖDER, K. Differential vascular functions of Nox family NADPH oxidases. Current Opinion in Lipidology, v. 19, n. 5, p. 513-518, out. 2008.

BRENER, Z. Therapeutic activity and criterion of cure on mice experimentally infected with Trypanosoma cruzi. Revista Do Instituto De Medicina Tropical De Sao Paulo, v. 4, p. 389-396, dez. 1962. 
BRENER, Z.; GAZZINELLI, R. T. Immunological control of Trypanosoma cruzi infection and pathogenesis of Chagas' disease. International Archives of Allergy and Immunology, v. 114, n. 2, p. 103-110, out. 1997.

BRUUNSGAARD, $\mathrm{H}$. et al. A high plasma concentration of TNF-alpha is associated with dementia in centenarians. The Journals of Gerontology. Series A, Biological Sciences and Medical Sciences, v. 54, n. 7, p. M357-364, jul. 1999.

BUSTAMANTE, J. M. et al. Reinfections and Trypanosoma cruzi strains can determine the prognosis of the chronic chagasic cardiopathy in mice. Parasitology Research, v. 100, n. 6, p. 1407-1410, maio 2007.

CAI, C. W. et al. Th17 Cells Are More Protective Than Th1 Cells Against the Intracellular Parasite Trypanosoma cruzi. PLOS Pathogens, v. 12, n. 10, p. e1005902, 3 out. 2016.

CALDEIRA, J. C.; FRANCI, C. R. Prolactin and corticosterone secretion in response to acute stress after paraventricular nucleus lesion by ibotenic acid. Brain Research Bulletin, v. 52, n. 6, p. 483-489, ago. 2000.

CANCRO, M. P. et al. B cells and aging: molecules and mechanisms. Trends in Immunology, v. 30, n. 7, p. 313-318, jul. 2009.

CARDILLO, F. et al. B cells modulate $T$ cells so as to favour $T$ helper type 1 and CD8+ T-cell responses in the acute phase of Trypanosoma cruzi infection. Immunology, v. 122, n. 4, p. 584-595, dez. 2007.

CAROCHO, M.; FERREIRA, I. C. F. R. A review on antioxidants, prooxidants and related controversy: natural and synthetic compounds, screening and analysis methodologies and future perspectives. Food and Chemical Toxicology: An International Journal Published for the British Industrial Biological Research Association, v. 51, p. 15-25, jan. 2013.

CARUSO, C. et al. Inflammation and life-span. Science (New York, N.Y.), v. 307, n. 5707, p. 208-209; author reply 208-209, 14 jan. 2005.

CERON, C. S. et al. Vascular oxidative stress: a key factor in the development of hypertension associated with ethanol consumption. Current Hypertension Reviews, v. 10 , n. 4 , p. 213-222, 2014.

CHAIMOWICZ, F. A saúde dos idosos brasileiros às vésperas do século $X X I$ : problemas, projeções e alternativas. Revista de Saúde Pública, v. 31, n. 2, p. 184200, abr. 1997.

CHATELAIN, E.; KONAR, N. Translational challenges of animal models in Chagas disease drug development: a review. Drug Design, Development and Therapy, v. 9, p. 4807-4823, 19 ago. 2015.

CHEN, Q. et al. Oxidative DNA damage and senescence of human diploid fibroblast cells. Proceedings of the National Academy of Sciences of the United States of America, v. 92, n. 10, p. 4337-4341, 9 maio 1995. 
CIUBOTARIU, R. et al. Specific Suppression of Human CD4+ Th Cell Responses to Pig MHC Antigens by CD8+CD28- Regulatory $T$ Cells. The Journal of Immunology, v. 161, n. 10, p. 5193-5202, 15 nov. 1998.

CORREAA-DE-SANTANA, E. et al. Hypothalamus-pituitary-adrenal axis during Trypanosoma cruzi acute infection in mice. Journal of Neuroimmunology, v. 173, n. 1-2, p. 12-22, abr. 2006.

COURA, J. R. Chagas disease: control, elimination and eradication. Is it possible? Memórias do Instituto Oswaldo Cruz, v. 108, n. 8, p. 962-967, dez. 2013.

COURA, J. R.; BORGES-PEREIRA, J. Chagas disease: 100 years after its discovery. A systemic review. Acta Tropica, v. 115, n. 1-2, p. 5-13, ago. 2010.

COURA, J. R.; BORGES-PEREIRA, J. Chagas disease: What is known and what should be improved: a systemic review. Revista da Sociedade Brasileira de Medicina Tropical, v. 45, n. 3, p. 286-296, jun. 2012.

COURA, J. R.; BORGES-PEREIRA, J. Chagas disease: 100 years after its discovery. A systemic review. Acta Tropica, v. 115, n. 1-2, p. 5-13, [s.d.].

COUTINHO, A. E.; CHAPMAN, K. E. The anti-inflammatory and immunosuppressive effects of glucocorticoids, recent developments and mechanistic insights. Molecular and Cellular Endocrinology, v. 335, n. 1, p. 2-13, 15 mar. 2011.

CRIGHTON, M. H.; PUPPIONE, A. A. Geriatric neutrophils: implications for older adults. Seminars in Oncology Nursing, v. 22, n. 1, p. 3-9, fev. 2006.

CRISTOFANON, S. et al. Oxidative, multistep activation of the noncanonical NFkappaB pathway via disulfide Bcl-3/p50 complex. FASEB journal: official publication of the Federation of American Societies for Experimental Biology, v. 23, n. 1, p. 45-57, jan. 2009.

DA SILVEIRA, A. B. M. et al. Characterization of the presence and distribution of Foxp3(+) cells in chagasic patients with and without megacolon. Human Immunology, v. 70, n. 1, p. 65-67, jan. 2009.

DAVENPORT, M. P.; PRICE, D. A.; MCMICHAEL, A. J. The T cell repertoire in infection and vaccination: implications for control of persistent viruses. Current Opinion in Immunology, v. 19, n. 3, p. 294-300, jun. 2007.

DE ANGULO, A. et al. Age-related increase in IL-17 activates pro-inflammatory signaling in prostate cells. The Prostate, v. 75, n. 5, p. 449-462, 1 abr. 2015.

DE ARAÚJO, F. F. et al. Foxp3+CD25(high) CD4+ regulatory $T$ cells from indeterminate patients with Chagas disease can suppress the effector cells and cytokines and reveal altered correlations with disease severity. Immunobiology, v. 217, n. 8, p. 768-777, ago. 2012.

DE LA FUENTE, M. et al. Changes with age in peritoneal macrophage functions. Implication of leukocytes in the oxidative stress of senescence. Cellular and 
Molecular Biology (Noisy-Le-Grand, France), v. 50 Online Pub, p. OL683-690, 2004.

DE MARTINIS MASSIMO et al. Inflamm-ageing and lifelong antigenic load as major determinants of ageing rate and longevity. FEBS Letters, v. 579 , n. 10, p. 20352039, 11 mar. 2005.

DE MEIS, J. et al. Atrophy of mesenteric lymph nodes in experimental Chagas' disease: differential role of Fas/Fas-L and TNFRI/TNF pathways. Microbes and Infection, v. 8, n. 1, p. 221-231, 1 jan. 2006.

DIAS, J. C. P.; COURA, J. R. Clínica e terapêutica da doença de Chagas: uma abordagem prática para o clínico geral. [s.I.] Editora FIOCRUZ, 1997.

DIXIT, V. D. Thymic fatness and approaches to enhance thymopoietic fitness in aging. Current opinion in immunology, v. 22, n. 4, p. 521-528, ago. 2010.

DORIA, G.; FRASCA, D.; COVELLI, V. An Immunological Approach to Aginga. Annals of the New York Academy of Sciences, v. 673, n. 1, p. 226-230, 1 dez. 1992.

DOSREIS, G. A. et al. The importance of aberrant T-cell responses in Chagas disease. Trends in Parasitology, v. 21, n. 5, p. 237-243, maio 2005.

DOUGALL, W. C.; NICK, H. S. Manganese superoxide dismutase: a hepatic acute phase protein regulated by interleukin-6 and glucocorticoids. Endocrinology, v. 129, n. 5, p. 2376-2384, nov. 1991.

ELIAS, L. L. et al. Effect of plasma osmolality on pituitary-adrenal responses to corticotropin-releasing hormone and atrial natriuretic peptide changes in central diabetes insipidus. The Journal of Clinical Endocrinology and Metabolism, v. 82, n. 4, p. 1243-1247, abr. 1997.

ELIAS, P. C. L. et al. Hypothalamic-pituitary-adrenal axis up-regulation in rats submitted to pituitary stalk compression. The Journal of Endocrinology, v. 180, n. 2, p. 297-302, fev. 2004.

ELIAS, R. M. et al. Role of CD28 in polyclonal and specific $T$ and B cell responses required for protection against blood stage malaria. Journal of Immunology (Baltimore, Md.: 1950), v. 174, n. 2, p. 790-799, 15 jan. 2005.

FELONATO, M. et al. CD28 Exerts Protective and Detrimental Effects in a Pulmonary Model of Paracoccidioidomycosis. Infection and Immunity, v. 78, n. 11, p. 49224935, 11 jan. 2010.

FERRAZ, M. L. et al. Absence of CD4+ T lymphocytes, CD8+ T lymphocytes, or B lymphocytes has different effects on the efficacy of posaconazole and benznidazole in treatment of experimental acute Trypanosoma cruzi infection. Antimicrobial Agents and Chemotherapy, v. 53, n. 1, p. 174-179, jan. 2009. 
FERREIRA, A. L.; MATSUBARA, L. S. Radicais livres: conceitos, doenças relacionadas, sistema de defesa e estresse oxidativo. Revista da Associação Médica Brasileira (1992), p. 61-68, 1 jan. 1997.

FERREIRA, I. DE L. M.; SILVA, T. P. T. E. Transmission elimination of Chagas' disease by Triatoma infestans in Brazil: an historical fact. Revista da Sociedade Brasileira de Medicina Tropical, v. 39, n. 5, p. 507-509, out. 2006.

FILIPIN, M. D. V. et al. DHEA and testosterone therapies in Trypanosoma cruziinfected rats are associated with thymic changes. Research in Veterinary Science, v. 89, n. 1, p. 98-103, ago. 2010.

FRANCESCHI, C. et al. Successful immunosenescence and the remodelling of immune responses with ageing. Nephrology, Dialysis, Transplantation: Official Publication of the European Dialysis and Transplant Association - European Renal Association, v. 11 Suppl 9, p. 18-25, 1996.

FRASCA, D.; BLOMBERG, B. B. Aging affects human B cell responses. Journal of Clinical Immunology, v. 31, n. 3, p. 430-435, jun. 2011.

FREIRE-DE-LIMA, C. G. et al. Uptake of apoptotic cells drives the growth of a pathogenic trypanosome in macrophages. Nature, v. 403, n. 6766, p. 199-203, 13 jan. 2000.

FÜLÖP, T. et al. Changes in apoptosis of human polymorphonuclear granulocytes with aging. Mechanisms of Ageing and Development, v. 96, n. 1-3, p. 15-34, jun. 1997.

GALVÃO DA SILVA, A. P.; JACYSYN, J. F.; ABRAHAMSOHN, I. D. A. Resistant mice lacking interleukin-12 become susceptible to Trypanosoma cruzi infection but fail to mount a T helper type 2 response. Immunology, v. 108, n. 2, p. 230-237, fev. 2003.

GAZZINELLI, R. T. et al. The microbicidal activity of interferon-gamma-treated macrophages against Trypanosoma cruzi involves an L-arginine-dependent, nitrogen oxide-mediated mechanism inhibitable by interleukin-10 and transforming growth factor-beta. European Journal of Immunology, v. 22, n. 10, p. 2501-2506, out. 1992.

GONGORA, M. C. et al. Role of extracellular superoxide dismutase in hypertension. Hypertension (Dallas, Tex.: 1979), v. 48, n. 3, p. 473-481, set. 2006.

GORONZY, J. J.; WEYAND, C. M. Ageing, autoimmunity and arthritis: T-cell senescence and contraction of T-cell repertoire diversity - catalysts of autoimmunity and chronic inflammation. Arthritis Research \& Therapy, v. 5, n. 5, p. 225-234, 2003.

GORONZY, J. J.; WEYAND, C. M. Immune aging and autoimmunity. Cellular and molecular life sciences: CMLS, v. 69, n. 10, p. 1615-1623, maio 2012.

HALLIWELL, B. Biochemistry of oxidative stress. Biochemical Society Transactions, v. 35, n. Pt 5, p. 1147-1150, nov. 2007. 
HARMAN, D. The aging process. Proceedings of the National Academy of Sciences of the United States of America, v. 78, n. 11, p. 7124-7128, nov. 1981.

HAURI-HOHL, M. M. et al. TGF-beta signaling in thymic epithelial cells regulates thymic involution and postirradiation reconstitution. Blood, v. 112, n. 3, p. 626-634, 1 ago. 2008.

HENG, T. S. P. et al. Effects of Castration on Thymocyte Development in Two Different Models of Thymic Involution. The Journal of Immunology, v. 175, n. 5, p. 2982-2993, 1 set. 2005.

HUANG, M.-C. et al. Nuclear factor-kappaB-dependent reversal of aging-induced alterations in $T$ cell cytokines. FASEB journal: official publication of the Federation of American Societies for Experimental Biology, v. 22, n. 7, p. 21422150, jul. 2008.

JANEWAY, C. A.; MEDZHITOV, R. Innate immune recognition. Annual Review of Immunology, v. 20, p. 197-216, 2002.

KAWAMOTO, E. M. et al. Age-related changes in nitric oxide activity, cyclic GMP, and TBARS levels in platelets and erythrocytes reflect the oxidative status in central nervous system. Age (Dordrecht, Netherlands), v. 35, n. 2, p. 331-342, abr. 2013.

$\mathrm{KIM}, \mathrm{H}$. et al. TNF- $\alpha$-induced up-regulation of intercellular adhesion molecule-1 is regulated by a Rac-ROS-dependent cascade in human airway epithelial cells. Experimental \& Molecular Medicine, v. 40, n. 2, p. 167-175, 30 abr. 2008.

KÖBERLE, F. Chagas' Disease and Chagas' Syndromes: The Pathology of American Trypanosomiasis. In: DAWES, B. (Ed.). . Advances in Parasitology. [s.I.] Academic Press, 1968. v. 6p. 63-116.

$\mathrm{KOCH}, \mathrm{S}$. et al. Human cytomegalovirus infection and T cell immunosenescence: a mini review. Mechanisms of Ageing and Development, v. 127, n. 6, p. 538-543, jun. 2006.

KOMATSU, N. et al. Heterogeneity of natural Foxp3+ T cells: a committed regulatory $\mathrm{T}$-cell lineage and an uncommitted minor population retaining plasticity. Proceedings of the National Academy of Sciences of the United States of America, v. 106, $n$. 6, p. 1903-1908, 10 fev. 2009.

LARBI, A. et al. Aging of the immune system as a prognostic factor for human longevity. Physiology (Bethesda, Md.), v. 23, p. 64-74, abr. 2008.

LEE, Y. et al. Exercise training attenuates age-dependent elevation of angiotensin II type 1 receptor and Nox2 signaling in the rat heart. Experimental Gerontology, v. 70, p. 163-173, out. 2015.

LEPLETIER, A. et al. Thymic atrophy in acute experimental Chagas disease is associated with an imbalance of stress hormones. Annals of the New York Academy of Sciences, v. 1262, p. 45-50, jul. 2012. 
LEVY, S. M. et al. Persistently low natural killer cell activity and circulating levels of plasma beta endorphin: risk factors for infectious disease. Life Sciences, v. 48, n. 2, p. 107-116, 1991.

LI, H.; HORKE, S.; FÖRSTERMANN, U. Oxidative stress in vascular disease and its pharmacological prevention. Trends in Pharmacological Sciences, v. 34, n. 6, p. 313-319, jun. 2013.

LIU, Y.; AMARNATH, S.; CHEN, W. Requirement of CD28 signaling in homeostasis/survival of TGF-beta converted CD4+CD25+ Tregs from thymic CD4+CD25- single positive T cells. Transplantation, v. 82, n. 7, p. 953-964, 15 out. 2006.

LOPES, E. S. G.; JÚNIOR, J. C. DO P. A INFLUÊNCIA DA CEPA Y DE Trypanosoma cruzi NO CORAÇÃO EM RATOS WISTAR MACHOS SUBMETIDOS AO PROCESSO DE ADRENALECTOMIA. Biodiversidade, v. 6, n. 1, 17 fev. 2010.

LOPES, M. F. et al. Activation-induced CD4+ $T$ cell death by apoptosis in experimental Chagas' disease. The Journal of Immunology, v. 154, n. 2, p. 744752, 15 jan. 1995.

MACHADO-SILVA, A. et al. How Trypanosoma cruzi deals with oxidative stress: Antioxidant defence and DNA repair pathways. Mutation Research. Reviews in Mutation Research, v. 767, p. 8-22, mar. 2016.

MAMELAK, M. Alzheimer's disease, oxidative stress and gammahydroxybutyrate. Neurobiology of Aging, v. 28, n. 9, p. 1340-1360, set. 2007.

MARIN-NETO, J. A.; RASSI, A. Update on Chagas heart disease on the first centenary of its discovery. Revista Espanola De Cardiologia, v. 62, n. 11, p. 12111216, nov. 2009.

MARTIN, D.; TARLETON, R. Generation, specificity, and function of CD8+ T cells in Trypanosoma cruzi infection. Immunological Reviews, v. 201, n. 1, p. 304-317, 1 out. 2004.

MARTINS, G. A. et al. CD28 is required for T cell activation and IFN-gamma production by CD4+ and CD8+ T cells in response to Trypanosoma cruzi infection. Microbes and Infection, v. 6, n. 13, p. 1133-1144, nov. 2004.

MATHUR, M. et al. CD28 interactions with either CD80 or CD86 are sufficient to induce allergic airway inflammation in mice. American Journal of Respiratory Cell and Molecular Biology, v. 21, n. 4, p. 498-509, out. 1999.

MAYER, B.; HEMMENS, B. Biosynthesis and action of nitric oxide in mammalian cells. Trends in Biochemical Sciences, v. 22, n. 12, p. 477-481, dez. 1997.

MIGLIORATI, G. et al. Dexamethasone and interleukins modulate apoptosis of murine thymocytes and peripheral T-lymphocytes. Pharmacological Research, v. 30, n. 1, p. 43-52, jul. 1994. 
MILLS, K. H. G. Regulatory T cells: friend or foe in immunity to infection? Nature Reviews. Immunology, v. 4, n. 11, p. 841-855, nov. 2004.

MINOPRIO, P. et al. Immunobiology of Murine T Cruzi Infection: The Predominance of Parasite-nonspecific Responses and the Activation of TCRIT Cells. Immunological Reviews, v. 112, n. 1, p. 183-207, 1 dez. 1989.

MIYAHIRA, Y. et al. Critical Contribution of CD28-CD80/CD86 Costimulatory Pathway to Protection from Trypanosoma cruzi Infection. Infection and Immunity, v. 71, n. 6, p. 3131-3137, 6 jan. 2003.

MIYAO, T. et al. Plasticity of Foxp3(+) T cells reflects promiscuous Foxp3 expression in conventional T cells but not reprogramming of regulatory T cells. Immunity, v. 36, n. 2, p. 262-275, 24 fev. 2012.

MLADENOV, M. et al. The relationship between antioxidant enzymes and lipid peroxidation in senescent rat erythrocytes. Physiological Research, v. 64, n. 6, p. 891-896, 2015.

MONTALVÃO, F. et al. Apoptotic lymphocytes treated with IgG from Trypanosoma cruzi infection increase TNF-alpha secretion and reduce parasite replication in macrophages. European Journal of Immunology, v. 40, n. 2, p. 417-425, fev. 2010.

MONTOYA-ORTIZ, G. Immunosenescence, Aging, and Systemic Lupus Erythematous. Research article. Disponível em: <https://www.hindawi.com/journals/ad/2013/267078/>. Acesso em: 2 maio. 2018.

MORROW, J. D.; ROBERTS, L. J. The isoprostanes. Current knowledge and directions for future research. Biochemical Pharmacology, v. 51, n. 1, p. 1-9, 12 jan. 1996.

MUÑOZ-SARAVIA, S. G. et al. Chronic Chagas' heart disease: a disease on its way to becoming a worldwide health problem: epidemiology, etiopathology, treatment, pathogenesis and laboratory medicine. Heart failure reviews, v. 17, n. 1, p. 45-64, jan. 2012.

NOVAES, M. R. C. G. et al. Micronutrients supplementation during the senescence: implications for the immunological functions. Revista de Nutrição, v. 18, n. 3, p. 367-376, jun. 2005.

NUNES, M. C. P. et al. Chagas disease: an overview of clinical and epidemiological aspects. Journal of the American College of Cardiology, v. 62, n. 9, p. 767-776, 27 ago. 2013.

NUNES, M. P. et al. Activation-Induced T Cell Death Exacerbates Trypanosoma cruzi Replication in Macrophages Cocultured with CD4+ T Lymphocytes from Infected Hosts. The Journal of Immunology, v. 160, n. 3, p. 1313-1319, 1 fev. 1998.

OLIVERA, M. J. et al. Risk factors for treatment interruption and severe adverse effects to benznidazole in adult patients with Chagas disease. PLOS ONE, v. 12, $\mathrm{n}$. 9, p. e0185033, 26 set. 2017. 
OUYANG, X. et al. Potentiation of Th17 cytokines in aging process contributes to the development of colitis. Cellular Immunology, v. 266, n. 2, p. 208-217, 2011.

Oxidative Stress in Human Infectious Diseases - Present and Current Knowledge About Its Druggability | IntechOpen. Disponível em: </books/drugdiscovery/oxidative-stress-in-human-infectious-diseases-present-and-currentknowledge-about-its-druggability>. Acesso em: 2 maio. 2018.

PALMER, D. B. The effect of age on thymic function. Frontiers in Immunology, v. 4, p. 316, 7 out. 2013.

PALMERI, M. et al. Cytokine serum profile in a group of Sicilian nonagenarians. Journal of Immunoassay \& Immunochemistry, v. 33, n. 1, p. 82-90, jan. 2012.

PAOLISSO, G. et al. Advancing age and insulin resistance: role of plasma tumor necrosis factor-alpha. The American Journal of Physiology, v. 275, n. 2 Pt 1, p. E294-299, ago. 1998.

PARAVICINI, T. M.; TOUYZ, R. M. NADPH oxidases, reactive oxygen species, and hypertension: clinical implications and therapeutic possibilities. Diabetes Care, v. 31 Suppl 2, p. S170-180, fev. 2008.

PASCUTTI, M. F. et al. Age-related increase in resistance to acute Trypanosoma cruzi infection in rats is associated with an appropriate antibody response. Scandinavian Journal of Immunology, v. 58, n. 2, p. 173-179, ago. 2003.

PAWELEC, G. et al. T cells and aging, January 2002 update. Frontiers in Bioscience: A Journal and Virtual Library, v. 7, p. d1056-1183, 1 maio 2002.

PAWELEC, G. Immunosenescence comes of age. Symposium on Aging Research in Immunology: The Impact of Genomics. EMBO Reports, v. 8, n. 3, p. 220-223, mar. 2007.

PEDRA, R. DE A. et al. Desafio em saúde pública: tratamento etiológico da doença de Chagas na fase crônica. Revista da Faculdade de Ciências Médicas de Sorocaba, v. 13, n. 2, p. 5-9, 27 jun. 2011.

PÉREZ, A. R. et al. Thymus atrophy during Trypanosoma cruzi infection is caused by an immuno-endocrine imbalance. Brain, Behavior, and Immunity, v. 21, n. 7, p. 890-900, out. 2007.

PHILLIPS, J. A. et al. IL-7 Gene Therapy in Aging Restores Early Thymopoiesis without Reversing Involution. The Journal of Immunology, v. 173, n. 8, p. 48674874, 15 out. 2004.

RESENDE, L. A. P. R. DE et al. Temporal analysis of cardiac frequency variability in basal condition in elderly chagasic subjects in indeterminate form in endemic área. Revista da Sociedade Brasileira de Medicina Tropical, v. 36, n. 6, p. 703-706, dez. 2003. 
RODRIGUES COURA, J. The main sceneries of Chagas disease transmission. The vectors, blood and oral transmissions - A comprehensive review. Memorias do Instituto Oswaldo Cruz, v. 0, 2 dez. 2014.

ROGGERO, E. et al. Endogenous glucocorticoids cause thymus atrophy but are protective during acute Trypanosoma cruzi infection. The Journal of Endocrinology, v. 190, n. 2, p. 495-503, ago. 2006.

ROTTENBERG, M. et al. Modulation of both interleukin 2 receptor expression and interleukin 2 production during experimental murine Trypanosoma cruzi infection. Scandinavian Journal of Immunology, v. 30, n. 1, p. 65-72, jul. 1989.

SALLES, N. et al. Expression of mRNA for ROS-generating NADPH oxidases in the aging stomach. Experimental Gerontology, v. 40, n. 4, p. 353-357, abr. 2005.

SANSONI, $\mathrm{P}$. et al. The immune system in extreme longevity. Experimental Gerontology, Centenarians in Italy. v. 43, n. 2, p. 61-65, 1 fev. 2008.

SAURWEIN-TEISSL, M. et al. Lack of antibody production following immunization in old age: association with CD8(+)CD28(-) T cell clonal expansions and an imbalance in the production of Th1 and Th2 cytokines. Journal of Immunology (Baltimore, Md.: 1950), v. 168, n. 11, p. 5893-5899, 1 jun. 2002.

SciELO Brasil - www.scielo.br. Disponível em: <http://www.scielo.br/scielo.php?script=sci_nlinks\&ref=000078\&pid=S00740276201000070002100019\&Ing=en>. Acesso em: 8 maio. 2018.

SEMPOWSKI, G. D. et al. Leukemia inhibitory factor, oncostatin M, IL-6, and stem cell factor mRNA expression in human thymus increases with age and is associated with thymic atrophy. Journal of Immunology (Baltimore, Md.: 1950), v. 164, n. 4, p. 2180-2187, 15 fev. 2000.

SHARMA, J. et al. The absence of myocardial calcium-independent phospholipase $A 2 \gamma$ results in impaired prostaglandin E2 production and decreased survival in mice with acute Trypanosoma cruzi infection., The Absence of Myocardial CalciumIndependent Phospholipase A2y Results in Impaired Prostaglandin E2 Production and Decreased Survival in Mice with Acute Trypanosoma cruzi Infection. Infection and immunity, Infection and Immunity, v. 81, 81, n. 7, 7, p. 2278, 2278-2287, jul. 2013.

SHARMA, J. et al. Absence of calcium-independent phospholipase A2 $\beta$ impairs platelet-activating factor production and inflammatory cell recruitment in Trypanosoma cruzi-infected endothelial cells. Physiological Reports, v. 2, n. 1, 6 jan. 2014.

SIMPSON, R. J. Aging, persistent viral infections, and immunosenescence: can exercise "make space"? Exercise and Sport Sciences Reviews, v. 39, n. 1, p. 2333, jan. 2011.

SOLANA, R.; PAWELEC, G.; TARAZONA, R. Aging and innate immunity. Immunity, v. 24, n. 5 , p. $491-494$, maio 2006. 
STEINMANN, G. G.; KLAUS, B.; MÜLLER-HERMELINK, H.-K. The Involution of the Ageing Human Thymic Epithelium is Independent of Puberty. Scandinavian Journal of Immunology, v. 22, n. 5, p. 563-575, 1 nov. 1985.

SWAIN, S. L.; BLOMBERG, B. B. Immune senescence: new insights into defects but continued mystery of root causes. Current Opinion in Immunology, v. 25, n. 4, p. 495-497, ago. 2013.

SYSLOVÁ, K. et al. Multimarker Screening of Oxidative Stress in Aging. Research article. Disponível em: <https://www.hindawi.com/journals/omcl/2014/562860/>. Acesso em: 2 maio. 2018.

TAJIMA, M. et al. The redox state of glutathione regulates the hypoxic induction of HIF-1. European Journal of Pharmacology, v. 606, n. 1-3, p. 45-49, 15 mar. 2009.

TAKEDA, K.; AKIRA, S. Toll-like receptors in innate immunity. International Immunology, v. 17, n. 1, p. 1-14, jan. 2005.

TANG, Q. et al. Cutting edge: CD28 controls peripheral homeostasis of CD4+CD25+ regulatory $T$ cells. Journal of Immunology (Baltimore, Md.: 1950), v. 171, n. 7, p. 3348-3352, 1 out. 2003.

TARAZONA, R. et al. Basic biology and clinical impact of immunosenescence. Experimental Gerontology, v. 37, n. 2-3, p. 183-189, mar. 2002.

TARLETON, R. L. Chagas disease: a role for autoimmunity? Trends in Parasitology, v. 19, n. 10, p. 447-451, out. 2003.

TEIXEIRA, D. E. et al. Interactive Multimedia to Teach the Life Cycle of Trypanosoma cruzi, the Causative Agent of Chagas Disease. PLoS Neglected Tropical Diseases, v. 6, n. 8,28 ago. 2012.

TERENZI, F. et al. Bacterial Lipopeptides Induce Nitric Oxide Synthase and Promote Apoptosis through Nitric Oxide-independent Pathways in Rat Macrophages. Journal of Biological Chemistry, v. 270, n. 11, p. 6017-6021, 17 mar. 1995.

THOMAN, M. L. The pattern of T lymphocyte differentiation is altered during thymic involution. Mechanisms of Ageing and Development, v. 82, n. 2, p. 155-170, 8 ago. 1995.

TOSTES, S. et al. Myocardiocyte apoptosis in heart failure in chronic Chagas' disease. International Journal of Cardiology, v. 99, n. 2, p. 233-237, 18 mar. 2005.

TOUYZ, R. M.; BRIONES, A. M. Reactive oxygen species and vascular biology: implications in human hypertension. Hypertension Research: Official Journal of the Japanese Society of Hypertension, v. 34, n. 1, p. 5-14, jan. 2011.

URBINA, J. A. New Advances in the Management of a Long-Neglected Disease. Clinical Infectious Diseases, v. 49, n. 11, p. 1685-1687, 1 dez. 2009. 
URBINA, J. A. Recent Clinical Trials for the Etiological Treatment of Chronic Chagas Disease: Advances, Challenges and Perspectives. Journal of Eukaryotic Microbiology, v. 62, n. 1, p. 149-156, 1 jan. 2015.

UTSUYAMA, M. et al. Impairment of signal transduction in $\mathrm{T}$ cells from old mice. Mechanisms of Ageing and Development, v. 93, n. 1-3, p. 131-144, fev. 1997.

UTTARA, B. et al. Oxidative Stress and Neurodegenerative Diseases: A Review of Upstream and Downstream Antioxidant Therapeutic Options. Current Neuropharmacology, v. 7, n. 1, p. 65-74, mar. 2009.

VALKO, M. et al. Free radicals and antioxidants in normal physiological functions and human disease. The International Journal of Biochemistry \& Cell Biology, v. 39, n. 1, p. 44-84, 1 jan. 2007.

VAN DUIN, D. et al. Prevaccine determination of the expression of costimulatory B7 molecules in activated monocytes predicts influenza vaccine responses in young and older adults. The Journal of Infectious Diseases, v. 195, n. 11, p. 1590-1597, 1 jun. 2007.

VASTO, S.; MALAVOLTA, M.; PAWELEC, G. Age and immunity. Immunity \& Ageing: I \& A, v. 3, p. 2, 24 fev. 2006.

VESPA, G. N.; CUNHA, F. Q.; SILVA, J. S. Nitric oxide is involved in control of Trypanosoma cruzi-induced parasitemia and directly kills the parasite in vitro. Infection and Immunity, v. 62, n. 11, p. 5177-5182, nov. 1994.

VILLEGAS, E. N. et al. Role of CD28 in the Generation of Effector and Memory Responses Required for Resistance to Toxoplasma gondii. The Journal of Immunology, v. 163, n. 6, p. 3344-3353, 15 set. 1999.

VISNER, G. A. et al. Regulation of manganese superoxide dismutase by lipopolysaccharide, interleukin-1, and tumor necrosis factor. Role in the acute inflammatory response. The Journal of Biological Chemistry, v. 265, n. 5, p. 28562864, 15 fev. 1990.

VITELLI-AVELAR, D. M. et al. Chagasic patients with indeterminate clinical form of the disease have high frequencies of circulating CD3+CD16-CD56+ natural killer $T$ cells and CD4+CD25High regulatory $T$ lymphocytes. Scandinavian Journal of Immunology, v. 62, n. 3, p. 297-308, set. 2005.

VITELLI-AVELAR, D. M. et al. Are increased frequency of macrophage-like and natural killer (NK) cells, together with high levels of NKT and CD4+CD25high T cells balancing activated CD8+ T cells, the key to control Chagas' disease morbidity? Clinical and Experimental Immunology, v. 145, n. 1, p. 81-92, jul. 2006.

WAGHABI, M. C. et al. Uptake of host cell transforming growth factor-beta by Trypanosoma cruzi amastigotes in cardiomyocytes: potential role in parasite cycle completion. The American Journal of Pathology, v. 167, n. 4, p. 993-1003, out. 2005. 
WEI, H. et al. Behavioural study of the D-galactose induced aging model in C57BL/6J mice. Behavioural Brain Research, v. 157, n. 2, p. 245-251, 28 fev. 2005.

WEINBERGER, B. et al. Biology of immune responses to vaccines in elderly persons. Clinical Infectious Diseases: An Official Publication of the Infectious Diseases Society of America, v. 46, n. 7, p. 1078-1084, 1 abr. 2008.

WHO I Chagas disease (American trypanosomiasis). Disponível em: <http://www.who.int/chagas/en/>. Acesso em: 2 maio. 2018.

WICK, G. et al. Diseases of aging. Vaccine, v. 18, n. 16, p. 1567-1583, 25 fev. 2000.

YANG, Y.; WILSON, J. M. CD40 ligand-dependent T cell activation: requirement of B7-CD28 signaling through CD40. Science (New York, N.Y.), v. 273, n. 5283, p. 1862-1864, 27 set. 1996.

YELINOVA, V. et al. Studies of human and rat blood under oxidative stress: changes in plasma thiol level, antioxidant enzyme activity, protein carbonyl content, and fluidity of erythrocyte membrane. Biochemical and Biophysical Research Communications, v. 221, n. 2, p. 300-303, 16 abr. 1996.

YOGI, A. et al. Ethanol-induced vasoconstriction is mediated via redox-sensitive cyclo-oxygenase-dependent mechanisms. Clinical Science (London, England: 1979), v. 118, n. 11, p. 657-668, 9 mar. 2010.

YOSHIDA, N. Molecular mechanisms of Trypanosoma cruzi infection by oral route. Memorias Do Instituto Oswaldo Cruz, v. 104 Suppl 1, p. 101-107, jul. 2009.

YOSHIDA, N.; TYLER, K. M.; LLEWELLYN, M. S. Invasion mechanisms among emerging food-borne protozoan parasites. Trends in Parasitology, v. 27, n. 10, p. 459-466, out. 2011.

ZAMBRANO, E.; REYES-CASTRO, L. A.; NATHANIELSZ, P. W. Aging, glucocorticoids and developmental programming. Age (Dordrecht, Netherlands), v. 37 , n. 3, p. 9774 , jun. 2015.

ZANNI, F. et al. Marked increase with age of type 1 cytokines within memory and effector/cytotoxic CD8+ $T$ cells in humans: a contribution to understand the relationship between inflammation and immunosenescence. Experimental Gerontology, v. 38, n. 9, p. 981-987, set. 2003.

ZHANG, J. et al. Apoptosis in a canine model of acute Chagasic myocarditis. Journal of Molecular and Cellular Cardiology, v. 31, n. 3, p. 581-596, mar. 1999.

ZUO, Z. et al. Aging-related kidney damage is associated with a decrease in klotho expression and an increase in superoxide production. Age (Dordrecht, Netherlands), v. 33, n. 3, p. 261-274, set. 2011. 
ANEXOS 
UAVERSRADE DE SÃOPAUIO

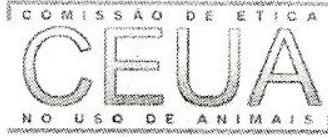

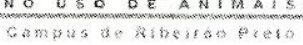

\section{UNIVERSIDADE DE SÃO PAULO}

Campus de Ribeirão Preto

Comissâto de Grica no Uso de Anmais

\section{E R T I F I C A D O}

Certificamos que o projeto intitulado "Consequências da imunossenescência frente à infecção experimental por Trypanosoma cruzi", protocolo $\mathrm{n}^{\circ}$ 2014.1.928.53.0, sob a responsabilidade de Rafaela Pravato Colato e Gabriela Bisson que envolve a utilização de animais pertencentes ao filo Chordata, subfilo Vertebrata (exceto o homem) para fins de pesquisa científica encontra-se de acordo com os preceitos da Lei $n^{\circ} 11.794$, de 8 de outubro de 2008, do Decreto ${ }^{\circ} 6.899$, de 15 de julho de 2009, e com as normas editadas pelo Conselho Nacional de Controle da Experimentação Animal (CONCEA), e foi aprovado pela Comissão de Ética no Uso de Animais da Prefeitura de Campus de Ribeirão Preto (CEUA PUSP-RP) em reunião de $31 / 07 / 2015$.

\begin{tabular}{|c|c|}
\hline Vigência do Projeto & $01 / 08 / 2015$ a $31 / 11 / 2017$ \\
\hline Espécie/Linhagem & Rattus norvegicus/wistar \\
\hline $\mathrm{N}^{\circ}$ de animais & 48 \\
\hline Peso/Idade & 5 semanas $(\mathrm{n}=24)$ e 18 meses $(\mathrm{n}=24)$ \\
\hline Sexo & Macho \\
\hline Origem & Biotério de Criação da PUSP-RP \\
\hline
\end{tabular}

Ribeirão Preto, 18 de agosto de 2015.

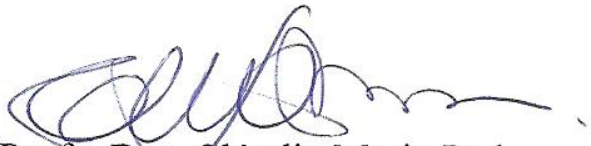

Profa. Dra. Cláudia Maria Padovan

Presidente da CEUA PUSP-RP 


\section{Interleukin-17, oxidative stress, and inflammation: role of melatonin during Trypanosoma cruzi infection}

\begin{abstract}
Although the exact etiology of Chagas' disease remains unknown, the inflammatory process and oxidative stress are believed to be the main contributors to the dysfunction and pathogenesis during chronic Trypanosoma cruzi infection. Our hypothesis is that melatonin administered for 2 months daily could modulate the oxidative stress and the inflammatory response during the chronic infection. Flow cytometric analysis of macrophages and antigen-presenting cells (APC), expression of RT1B as well as LFA-1 and MCP-1 in CD4 $4^{+}$and $\mathrm{CD} 8{ }^{+} \mathrm{T}$ cells and levels of interleukin-17A were assessed. The oxidative stress was evaluated through lipid peroxidation (LPO) analysis on the plasma of thiobarbituric acid-reactive substances (TBARS) and nitric oxide production. Decreased concentrations of nitrite and TBARS were found in infected and melatonin-treated animals, as well as a rising trend in the production of IL-17A as compared to infected and untreated counterparts. A significant decrease was found in the percentages of $\mathrm{CD} 4{ }^{+}$and $\mathrm{CD} 8^{+} \mathrm{T}$ lymphocytes MCP-1 producers for infected and melatonin-treated rats. Reduced percentage of $\mathrm{CD} 8^{+} \mathrm{T}$ cells producing LFA-1 was observed in control and melatonin-treated animals as compared to untreated rats. The cellular response of peritoneal APC cells and macrophages significantly dropped in infected and treated animals. As an endpoint, the use of antioxidant compounds such as melatonin emerges as a new and promising approach to control the oxidative stress during the chronic Chagas' disease partially mediated through the abrogation of LPO and the prevention of the inflammatory response and can be used for further investigation on treatment trials for other infectious diseases.
\end{abstract}

\section{Vânia Brazão ${ }^{1}$, Rafaela Pravato Colato ${ }^{1}$, Fabricia Helena Santello ${ }^{1}$, Marina Del Vecchio Filipin ${ }^{1}$, Míriam Paula Alonso Toldo ${ }^{1}$, Gabriel Tavares do Vale ${ }^{2}$, Carlos Renato Tirapelli ${ }^{2}$ and José Clóvis do Prado Júnior ${ }^{1}$}

\begin{abstract}
${ }^{1}$ College of Pharmaceutical Sciences of Ribeirão Preto (FCFRP), University of São Paulo, Ribeirão Preto, SP, Brazil; ${ }^{2}$ Department of Psychiatric Nursing and Human Sciences, Laboratory of Pharmacology, College of Nursing of Ribeirão Preto, USP, Ribeirão Preto, SP, Brazil

Key words: Chagas' disease, immune response, melatonin, oxidative stress, Trypanosoma cruzi

Address reprint requests to José Clóvis do Prado Júnior, Departamento de Análises Clínicas, Toxicológicas e Bromatológicas, Faculdade de Ciências Farmacêuticas de Ribeirão Preto FCFRP-USP, Universidade de São Paulo, Avenida do Café s/nº, 14040-903 Ribeirão Preto, SP, Brazil.

E-mail: jcprado@fcfrp.usp.br
\end{abstract}

Received August 24, 2015;

Accepted September 24, 2015.

\section{Introduction}

Melatonin (N-acetyl-5-methoxytryptamine) is a nightly secretory product of the pineal gland, and its production is controlled by the suprachiasmatic nucleus [1]. This indoleamine produces a wide range of biological responses in various target tissues, through receptor-mediated and receptor-independent mechanisms [2]. Melatonin's pleiotropic functions include the important role of a primary circadian pacemaker [3, 4], as well as acting as a highly effective antioxidant [3, 5], a regulator of antioxidative enzyme gene expression [6], a radical scavenger [7, 8], and an anti-inflammatory agent [9].

Melatonin is highly effective in reducing oxidative stress throughout the body [6,10], triggering increased activity of several antioxidant enzymes $[6,8]$, weakening reactive oxygen species (ROS) which trigger a damage to cardiolipin, a substance that plays a pivotal role in mitochondrial bioenergetics. Although the mechanisms used by melatonin and/or its metabolites to limit lipid peroxidation (LPO) are not fully understood, it is now recognized that melatonin can protect cellular proteins, lipids, and DNA from oxidative damage [11-13]. Conversely to most antioxidants, the amphiphilic nature of melatonin as well as its small molecular size helps this molecule to pass freely through cell membranes and morphophysiological barriers [14, 15].

Melatonin has also the ability to reduce gene expression and activities of inducible nitric oxide synthase (NOS) [16] and cyclooxygenase, limiting a variety of pro-inflammatory molecules such as leukotrienes, prostanoids, cytokines and adhesion molecules by regulating the transcriptional factor-kB $(\mathrm{NF}-\kappa \mathrm{B})$ [9]. It also reduces the recruitment of leukocytes to areas of injury thus limiting the oxidative and molecular damage [10].

Chagas' disease, caused by Trypanosoma cruzi, is considered an important neglected tropical disease. The overall prevalence of human $T$. cruzi infection is estimated at 9.8 million cases with a further 60 million considered at risk of contracting the illness [17]. In recent years, because of the increasing migration of infected persons from endemic areas to developed countries such as the United States, Spain, and Germany, among others, the scope of Chagas' disease threatens to expand exponentially outside of traditionally infected areas. According to Kirchhoff et al. [18], 13 million people from endemic Chagas' disease countries are living in the United States, and among them, 80,000-120,000 have a chronic T. cruzi infection [19]. 
Studying the actions of oral melatonin administration during T. cruzi infection, our research group [19, 20] described its beneficial effects in animals with cardiac inflammatory disease which is a hallmark of the chronic chagasic infection [21]. Recently, Brazão et al. [22] demonstrated that melatonin and zinc regulate the inflammatory and immunopathological processes during the late phase of infection.

The ability of melatonin to protect cells from LPO and oxidative stress is of special interest because recent data $[23,24]$ suggest that increased oxidative stress is considered an important factor associated with the progression of chronic Chagas' disease. Other studies have also shown that the intense inflammatory process, during the chronic stage of the disease, seems to participate in the pathogenesis of $T$. cruzi infection through its ability to induce differential expression of cytokines by monocytes and $\mathrm{T}$ cells, which results in an intense inflammatory reaction involving a massive presence of immune cells such as macrophages and TCD ${ }^{+}$lymphocytes.

Based on the critical lack of evidence about the actions of the current available drugs (benznidazole and nifurtimox) and the absence of an effective and feasible treatment for Chagas' disease, this study proposes the design of a rational therapeutic strategy using melatonin as a new approach targeting to protect animals through the abrogation of LPO and the prevention of the inflammatory response. For this purpose, we elected the use of melatonin as a possible substance able to modulate the immune response and the inflammatory process.

\section{Material and methods}

\section{Reagents and antibodies}

Melatonin, phorbol 12-myristate 13-acetate (PMA) ionomycin, LPS (Escherichia coli), RPMI 1640 medium, sulfanilamide, phosphoric acid solution, naphthylethylene diamine dihydrochloride, and Trypan solution were obtained from Sigma (St Louis, MO, USA). All anti-rat mAbs, Brefeldin A, and Cyto fix/Cyto perm buffer were purchased from BD PharMingen. Fetal Bovine Serum (FBS) was obtained from Gibco (Life Technologies/Gibco BRL). Stock solutions were diluted to the desired final concentration with medium, immediately before use.

\section{Animals and treatment}

All procedures involving animals were carried out in strict accordance with the current requirements of animal care guidelines and were approved by the local Ethics Committee (protocol number 08.1.835.53.5). For the purpose of this study, 20 male Wistar rats, weighing 90-100 g, were ordered from the Facility House of the University Campus of Ribeirão Preto. They were randomly divided into four groups with five rats in each group: control (C), melatonin control (MC), infected (I), and melatonin infected (MI). The animals were kept on a 12-h light/12-h dark cycle with commercial rodent diet and water available ad libitum. Rat bedding was changed 3 times/wk to avoid ammonia concentration from urine. Rats were orally treated with $0.1 \mathrm{~mL}$ of melatonin, which had been dissolved in polyethylene glycol 400 (PEG 400) at $5 \mathrm{mg} / \mathrm{kg}$ of body weight once a day. Melatonin was administered at the same time each day, beginning the day after inoculation and then every day until the end of the experiment (60 days after infection) [25].

\section{Experimental infection, parasites and euthanasia}

Rats were intraperitoneally (i.p.) inoculated with $1 \times 10^{5}$ blood trypomastigotes of the Y strain of T. cruzi [26]. Parasitemia was determined using Brener's method [27]. Animals were firstly anesthetized with tribromoethanol $2.5 \%$, by means of an intraperitoneal dose of $0.1 \mathrm{~mL} / 10 \mathrm{~g}$ of body weight. Soon after animal lost consciousness, they were decapitated. The assays were performed 60 days after infection.

\section{Preparation of tissues and cells}

Male Wistar rats were decapitated, and the spleens were excised. To obtain cell suspensions, the spleen tissues were cut into small fragments and dispersed by extrusion through a $70 \mu \mathrm{m}$ Nylon Cell Strainer and macerated in RPMI 1640 medium to produce a single cell suspension from which the cells extruded spontaneously. The remaining tissue fragments were eliminated by sedimentation. To obtain peritoneal cells, an injection of $5 \mathrm{~mL}$ of cold RPMI 1640 medium into the peritoneal cavity was carried out followed by a soft massage and peritoneal cells were harvested. The cells were centrifuged at $410 \mathrm{~g}$ for $15 \mathrm{~min}$, the pellet was resuspended in RPMI 1640 medium and diluted (1:10) with Trypan solution $(0.4 \%)$, and the cells were counted in a Neubauer chamber.

\section{Flow cytometry}

Cells from the peritoneal suspension and spleen organ were plated at a density of $2 \times 10^{6}$ cells/well in 96-well microplates. Following Fc receptor blocking, the cells were incubated with monoclonal antibodies, used in different color combinations: antimacrophage subset phycoerythrin (PE) to identify macrophages, anti-CD11bc-phycoerythrin-Cy7 (PE-Cy7) to antigen-presenting cells (APC) cells, anti-RT1B-phycoerythrin (PE) (Activation marker) and anti-CD11a-fluorescein isothiocyanate (FITC) to identify adhesion molecules. The stained cells were stored for analysis in PBS containing 1\% paraformaldehyde in sealed tubes in the dark. All steps were performed at $4^{\circ} \mathrm{C}$. Analysis of these cells was performed using a Becton Dickinson FACScan flow cytometer with DIVA-BD software (Becton Dickinson Immunocytometry Systems, San Jose, CA, USA).

\section{Stimulation assay and flow cytometric analysis of intracellular MCP-1}

$\mathrm{CD}^{+}{ }^{+}$and $\mathrm{CD}^{+}{ }^{+}$specific intracellular chemokine MCP-1 was measured using a flow cytometry assay. Briefly, spleen cells were plated at a density of $2 \times 10^{6}$ cells/well in 96-well microplates and stimulated with $5 \mu \mathrm{g} / \mathrm{mL}$ de phorbol 12-myristate 13-acetate (PMA) and $1 \mu \mathrm{g} / \mathrm{mL}$ ionomycin for 
$4 \mathrm{hr}$ at $37^{\circ} \mathrm{C}$ under $5 \% \mathrm{CO}_{2}$. Cytokine secretion was inhibited with $1 \mu \mathrm{M}$ Brefeldin A, a protein transport inhibitor that was added during the final $4 \mathrm{hr}$ of incubation. The cells were washed, and after blocking with anti-CD16/32 mAb, the cells were incubated with anti-CD3, CD4, and CD8 antibodies $\left(30 \mathrm{~min}, 4^{\circ} \mathrm{C}\right.$ in the dark) to detect surface expression. After surface staining, the cells were permeabilized by incubation with Cyto fix/Cyto perm buffer for $20 \mathrm{~min}$. After resuspension in perm/wash buffer, the cells were incubated with anti-MCP-1-PE diluted in Perm/Wash buffer at $4^{\circ} \mathrm{C}$ for $30 \mathrm{~min}$, washed, resuspended in PBS containing $1 \%$ paraformaldehyde and then stored in sealed tubes in the dark. Analysis of these cells was performed using a Becton Dickinson FACScan flow cytometer with DIVA-BD software (Becton Dickinson Immunocytometry Systems). The results are expressed as the percentage of cytokine $\mathrm{MCP}-1$-producing $\mathrm{CD} 4^{+}$and $\mathrm{CD} 8^{+} \mathrm{T}$ cells.

\section{Measurement of nitrite production}

Nitric oxide (NO) production was measured according to the method used by Brazão et al. [28]. Accumulated supernatant nitrite (a stable breakdown product of NO) was measured using the Griess reaction. Macrophage cells, harvested from the peritoneal cavity, were adjusted to a concentration of $5 \times 10^{6}$ cells $/ \mathrm{mL}$ and cultured in 96-well flat-bottomed plates, with or without LPS $(10 \mu \mathrm{g} / \mathrm{mL})$ (E. coli), at $37^{\circ} \mathrm{C}$ for $48 \mathrm{hr}$ in a $5 \% \mathrm{CO}_{2}$ atmosphere. Subsequently, the supernatants were collected, transferred to new 96-well flat-bottom culture plates and incubated with Griess reagent at room temperature for $5 \mathrm{~min}$. Griess reagent was prepared by mixing equal volumes of $1 \%$ sulfanilamide in $5 \%$ phosphoric acid solution and $0.1 \%$ naphthylethylene diamine dihydrochloride at room temperature for $5 \mathrm{~min}$. The absorbances were determined in triplicate at $540 \mathrm{~nm}$. The concentration of nitrite was obtained by comparison with a standard curve of serially diluted sodium nitrite and expressed in micromoles.

\section{Plasma measurement of TBARS}

The rats were decapitated and the blood samples (volume of $10 \mathrm{~mL}$ ) collected into chilled plastic tubes containing EDTA, and centrifuged for $20 \mathrm{~min}$ at $2000 \mathrm{~g}$ at $4^{\circ} \mathrm{C}$ for plasma separation and stored in Eppendorfs tubes at $-70^{\circ} \mathrm{C}$ prior to dosage. Plasma levels of thiobarbituric acid-reactive substances (TBARS) were measured using a colorimetric method as previously described [29]. Malondialdehyde (MDA) standards were diluted in the range of $0-50 \mathrm{nmol} / \mathrm{mL}$. TBARS values were expressed in $\mathrm{nmol} / \mathrm{ml}$ malondialdehyde equivalents.

\section{Enzyme-linked immunosorbent assay}

IL-17A levels in serum were determined using ELISA Kit (BioLegend, San Diego, CA, USA).

\section{Statistical analysis}

The results were expressed as means/standard error of mean. A value of $P<0.05$ was considered statistically significant. Differences among groups were determined by one-way ANOVA with Bonferroni's post-test. All statistical analyses were performed using Graph Pad Prism version 5.0 (GraphPad Software, Inc., San Diego, CA, USA).

\section{Results}

Our first objective in this study was to determine whether the use of antioxidants such as melatonin was associated with changes in the initiation and/or progression of LPO. For control animals, treated or not, no difference was observed in the plasma concentration of TBARS, a product of oxidative stress.

During the chronic T. cruzi infection, an increase $(P<0.001)$ in TBARS levels was noted in the infected and untreated animals, as compared to uninfected animals. Nevertheless, the antioxidant effect of melatonin was observed by protecting lipids from peroxidation, here revealed by the lowest and significant levels of TBARS $(P<0.001)$ (Fig. 1).

It has been demonstrated that $\mathrm{NO}$ can react with $\mathrm{O}_{2}^{-}$to produce $\mathrm{ONOO}^{-}$, a recognized initiator of LPO. For this reason, we examined whether the oral administration of melatonin affects the NO production. On experimental day 60 , nitrite concentration reached the lowest significant values for all melatonin-treated animals when compared to infected and untreated counterparts $(P<0.05)$ (Fig. 2).

To determine whether the melatonin administration was associated with changes in the IL-17 cytokine production profile, we infected Wistar rats with $T$. cruzi, and 60 days after infection, we found significant increased levels of IL-17, for any infected animal when compared to uninfected counterparts (Fig. 3). For the infected and melatonin-treated group, a rising trend in the production of IL-17A was observed as compared to infected and untreated counterparts.

During the initial phase of the inflammation process, enhanced ROS generation is observed leading to a concentration gradient that directs leukocyte recruitment to the injured tissue. Consequently, in our experiment, it was observed statistically significant decreased percentages of

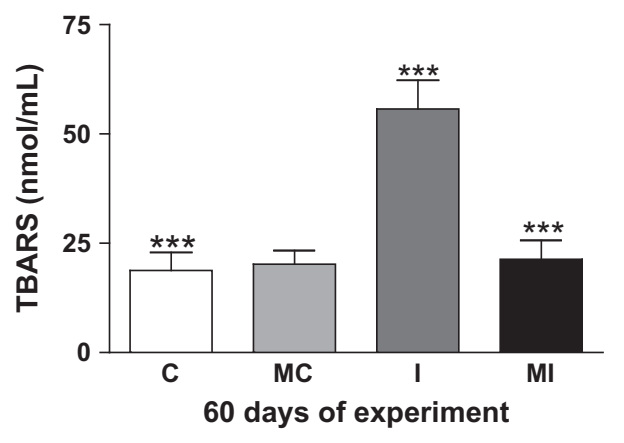

Fig. 1. Plasma concentration of TBARS, a marker of oxidative stress, from male Wistar rats infected with $1.0 \times 10^{5}$ blood trypomastigotes of the $\mathrm{Y}$ strain of $T$. cruzi on the 60th day postinfection of experimental disease, for the following groups: control (C), melatonin control (MC), infected (I), and melatonin infected (MI). One-way ANOVA with Bonferroni's multiple comparison test was used to compare groups $(* * * P<0.001)$. All data are expressed as mean \pm S.E.M. $n=5 /$ group/day of experiment. 

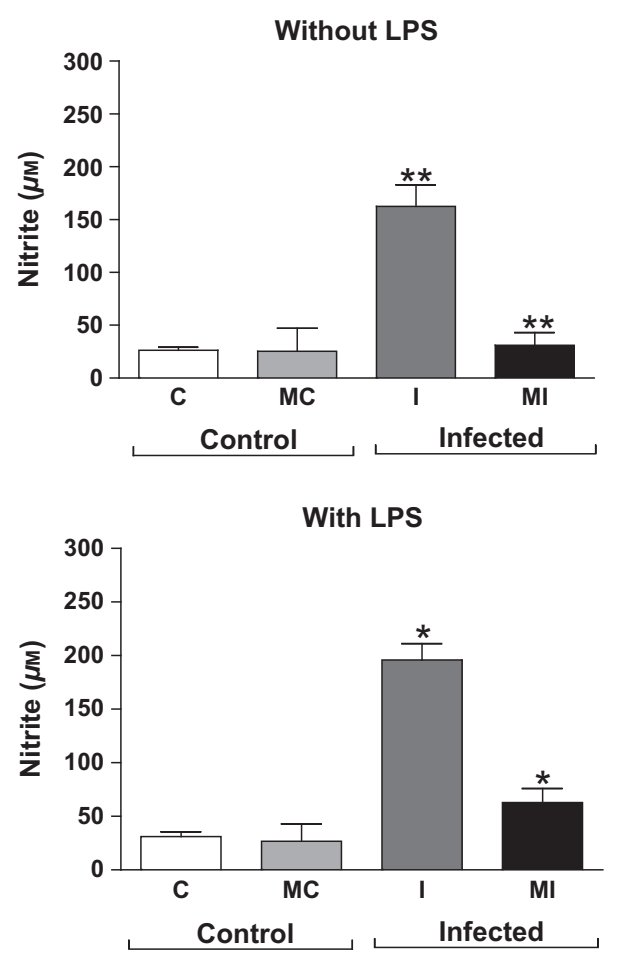

Fig. 2. Nitrite concentration $(\mu \mathrm{M})$ of cultured peritoneal macrophages harvested from male Wistar rats infected with $1.0 \times 10^{5}$ blood trypomastigotes of the $\mathrm{Y}$ strain of $T$. cruzi on the 60th day postinfection of experimental disease, for the following groups: control (C), melatonin control (MC), infected (I), and melatonin infected (MI). One-way ANOVA with Bonferroni's multiple comparison test was used to compare groups $(* P<0.05$; $* * P<0.01)$. All data are expressed as mean \pm S.E.M. $n=5 /$ group/day of experiment.

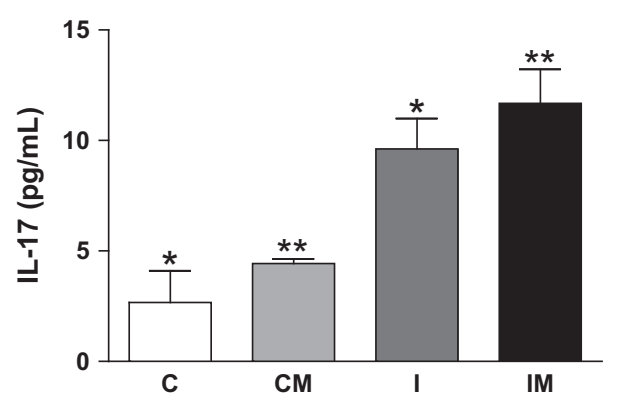

Fig. 3. IL-17 serum concentrations $(\mathrm{pg} / \mathrm{mL})$ in male Wistar rats infected with $1.0 \times 10^{5}$ blood trypomastigotes of the $\mathrm{Y}$ strain of T. cruzi on the 60th day postinfection of experimental disease, for the following groups: control (C), melatonin control (MC), infected (I), and melatonin infected (MI). One-way ANOVA with Bonferroni's multiple comparison test was used to compare groups $\left({ }^{*} P<0.05 ; \quad * * P<0.01\right)$. All data are expressed as mean \pm S.E.M. $n=5 /$ group $/$ day of experiment.

MCP-1, chemoattractant of mononuclear cells, in CD4 ${ }^{+}$ cells in melatonin-treated and noninfected animals as compared to infected and untreated ones. This study also showed that the percentages of both MCP-1-producing $\mathrm{CD}^{+} \mathrm{T}$ and $\mathrm{CD}^{+} \mathrm{T}$ cells were remarkably reduced in the spleen of infected and melatonin-treated animals $(P<0.001)$ (Fig. 4A,B).
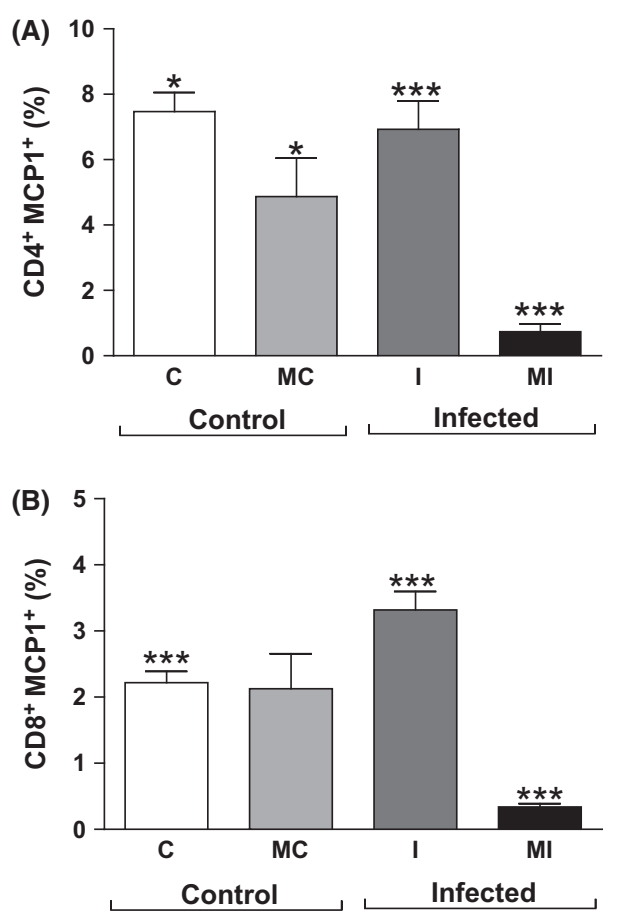

Fig. 4. Intracellular flow cytometry for $\mathrm{MCP}-1$ in $\mathrm{CD}^{+}(\mathrm{A})$ and $\mathrm{CD} 8^{+} \mathrm{T}$ cells $(\mathrm{B})$ from male Wistar rats i.p. infected with $1.0 \times 10^{5}$ blood trypomastigotes of the Y strain of $T$. cruzi on the 60th day postinfection, for the following groups: control (C), melatonin control (MC), infected (I), and melatonin infected (MI). One-way ANOVA with Bonferroni's multiple comparison test was used to compare groups $(* P<0.05 ; * * * P<0.001)$. All data are expressed as mean \pm S.E.M. $n=5 /$ group/day of experiment.

Following our aims, we investigated the ability of melatonin to modulate CD11a LFA-1 expression in chronic T. cruzi infection, a beta- 2 integrin also involved in the recruitment of cells to sites of inflammation. We observed that the percentages of CD8T cells expressing CD11a/ CD18 in melatonin-treated rats were diminished as compared to the control and untreated counterparts (Fig. 5). No difference was observed in the percentage of $\mathrm{CD} 4^{+}$ and $\mathrm{CD} 8{ }^{+} \mathrm{T}$ cells expressing CD11a/CD18 in the infected animals, either treated or not.

To determine the actual contribution of melatonin during the chronic $T$. cruzi infection, we examined whether the oral administration of this substance affects the innate immune response. For this purpose, in the treated groups, peritoneal macrophages were analyzed showing a significant drop when compared to the infected and untreated ones (Fig. 6A). Concerning spleen macrophages, our study showed that melatonin treatment did not affect the percentage of these cells for any group, regardless of the infection status (Fig. 6B). The percentage of peritoneal macrophages expressing RT1B in infected and untreated rats remained higher as compared to uninfected ones (Fig. 7). No difference was observed in the expression of activation markers (RT1B) in the peritoneal macrophages of infected animals, either treated or not (Fig. 7).

For peritoneal APC cells, a significant reduced number of these cells was observed in infected and melatonin-treated rats when compared to infected but untreated animals. 

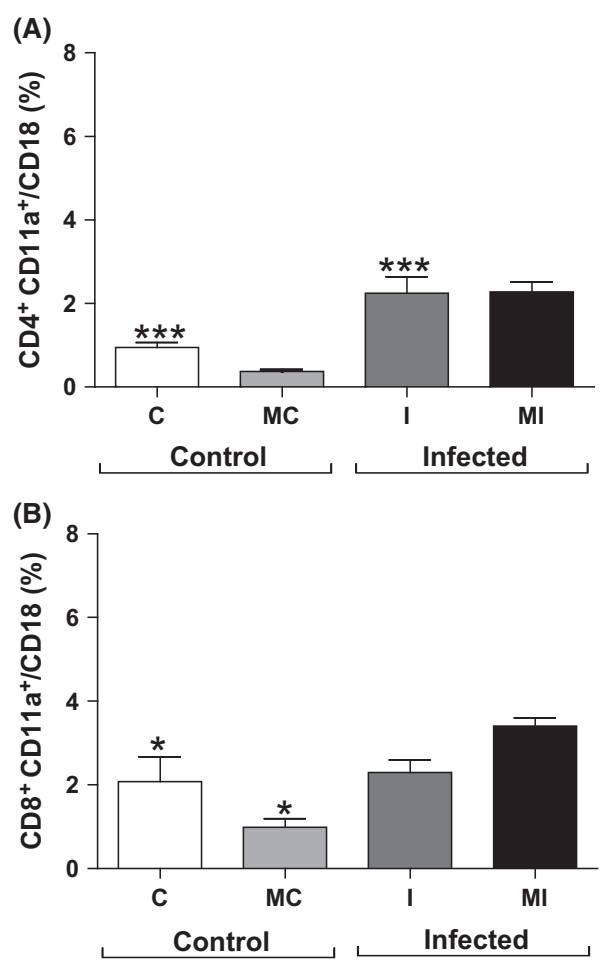

Fig. 5. CD11a/CD18 expression by $\mathrm{CD}^{+}$and $\mathrm{CD} 8^{+} \mathrm{T}$ lymphocytes of male Wistar rats i.p. infected with $1.0 \times 10^{5}$ blood trypomastigotes of the $\mathrm{Y}$ strain of T. cruzi on the 60th day postinfection of experimental disease, for the following groups: control (C), melatonin control (MC), infected (I), and melatonin infected (MI). One-way ANOVA with Bonferroni's multiple comparison test was used to compare groups $(* P<0.05$; $\left.{ }_{* * *} P<0.001\right)$. All data are expressed as mean \pm S.E.M. $\mathrm{n}=5$ / group/day of experiment.

Melatonin therapy did not affect spleen APC cell percentages for any treated group, either infected or not (Fig. 8B).

\section{Discussion}

Notably, in recent years, several researchers have demonstrated the importance of the oxidative stress in the pathogenesis of Chagas' disease [23, 24, 30, 31]. It has been also

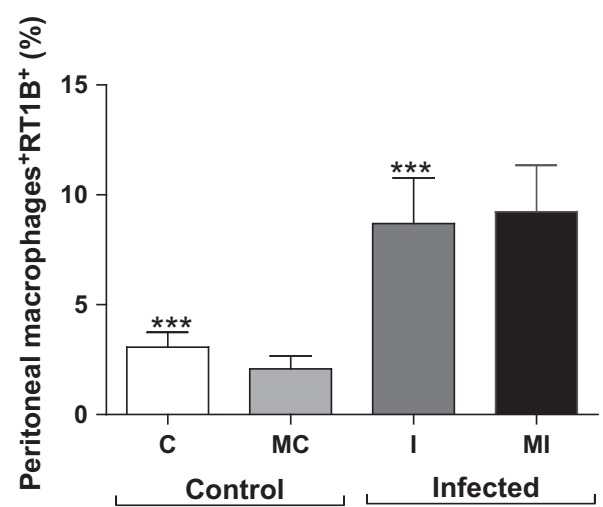

Fig. 7. Expression of activation-related cell surface molecules (RT1B) in peritoneal macrophages from male Wistar rats i.p. infected with $1.0 \times 10^{5}$ blood trypomastigotes of the $\mathrm{Y}$ strain of T. cruzi on the 60th day postinfection, for the following groups: control (C), melatonin control (MC), infected (I), and melatonin infected (MI). One-way ANOVA with Bonferroni's multiple comparison test was used to compare groups $(* * * P<0.001)$. All data are expressed as mean \pm S.E.M. $\mathrm{n}=5$ /group/day of experiment.

noted that the production ROS can activate the intracellular inflammatory signaling pathways promoting the migration of inflammatory cells across the endothelial barrier leading to the release of inflammatory mediators in various tissues [32], including cytokines produced by the activation of redox-regulated transcription factors such as NF- $\kappa$ B $[33,34]$.

Some compounds with antioxidant activity have received particular attention because of their potential role in modulating oxidative stress associated with chronic conditions, such as Chagas' disease. In fact, some studies have described the protective effects of antioxidant supplementation during chronic T. cruzi infection [30,35], counteracting the progressive oxidative stress associated with this infectious disease. Based on this background, we evaluated the effects of melatonin, a substance with proven antioxidant and immunomodulatory effects in a murine model of chronic $T$. cruzi infection.

One major function of melatonin is the ability of scavenging free radicals in oxygen metabolism, including those formed from $\mathrm{ONOO}^{-}$. This indolamine potentially
(A)

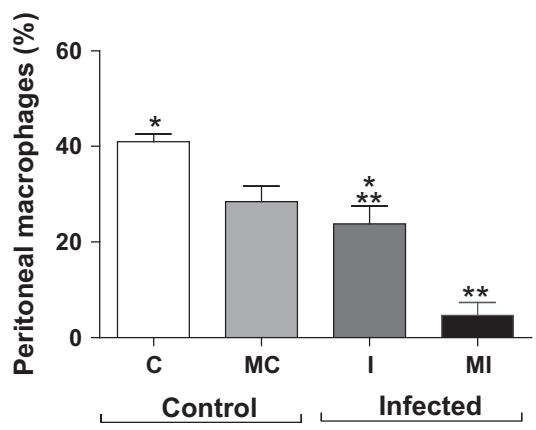

(B)

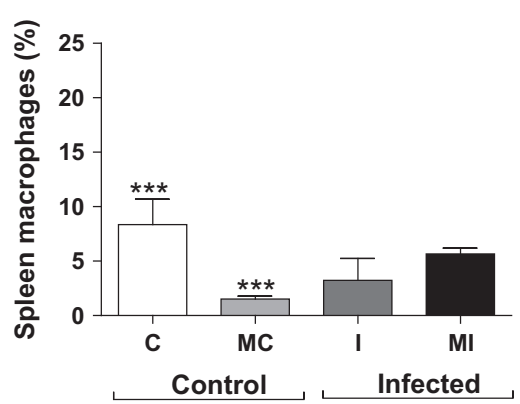

Fig. 6. Phenotypical analysis of peritoneal (A) and spleen (B) macrophages from male Wistar rats i.p. infected with $1.0 \times 10^{5}$ blood trypomastigotes of the Y strain of T. cruzi on the 60th day postinfection of experimental disease, for the following groups: control (C), melatonin control (MC), infected (I), and melatonin infected (MI). One-way ANOVA with Bonferroni's multiple comparison test was used to compare groups $\left(* P<0.05 ; * P<0.01\right.$, and $\left.{ }^{* * *} P<0.001\right)$. All data are expressed as mean \pm S.E.M. $\mathrm{n}=5 /$ group/day of experiment. 
(A)

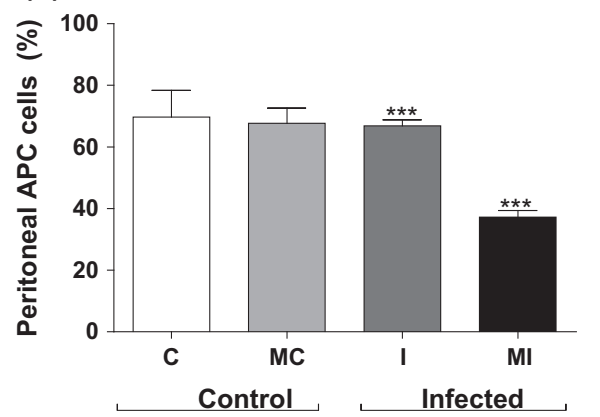

(B)

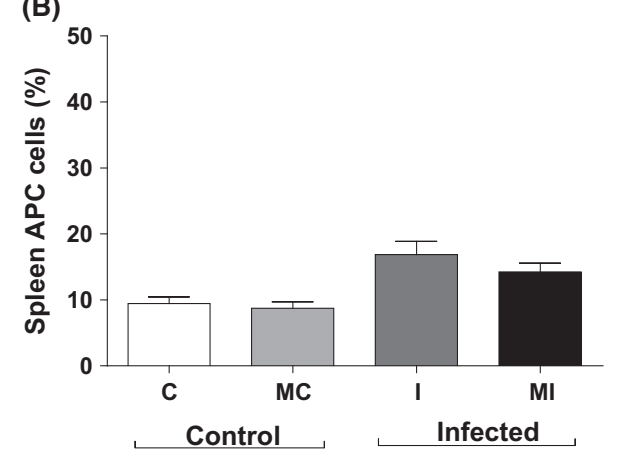

Fig. 8. Phenotypical analysis of antigen-presenting cells, from peritoneal cavity (A) and spleen (B) of male Wistar rats i.p. infected with $1.0 \times 10^{5}$ blood trypomastigotes of the $\mathrm{Y}$ strain of T. cruzi on the 60th day postinfection, for the following groups: control (C), melatonin control (MC), infected (I), and melatonin infected (MI). One-way ANOVA with Bonferroni's multiple comparison test was used to compare groups $(* * * P<0.001)$. All data are expressed as mean \pm S.E.M. $n=5 /$ group/day of experiment.

protects the cells against a wide variety of processes and agents that induce damage to DNA, proteins, and membranes. Besides scavenging NO, melatonin also inhibits one isoform of NOS, the enzyme that converts arginine to NO [36], controlling the LPO, as NO reacts with $\mathrm{O}_{2}^{-}$to form $\mathrm{ONOO}^{-}$, a well established initiator of LPO [13].

It is now well recognized that the excess of ROS can lead biomolecules (lipids, proteins, DNA), to oxidative damage, being a key factor in the pathogenesis and development of several disease processes including atherosclerosis, diabetes, rheumatoid arthritis, myocardial infarction, cardiovascular diseases, and chronic inflammation [37, 38]. In the present study, decreased concentrations of NO in infected and melatonin-treated animals were observed confirming the antioxidant effect of this substance. Therefore, our results are in accordance with several authors who suggest that melatonin treatment limits the production of excessive amounts of NO [39, 40].

Although the exact mechanisms by which melatonin and/or its metabolites function to limit LPO are undoubtedly very complex and still not completely clarified, it is now well established that LPO and oxidative stress can also be efficiently attenuated by melatonin [12]. Several authors have shown that melatonin has the ability to gain access to the major sites of free radical generation, because it is normally embedded in an outer location of the lipid membrane layer near the polar heads of these molecules, and its juxtaposition to the lipid molecules allows melatonin to protect them from the onslaught of the free radicals, mainly inside the mitochondria [41] where free radical generation is especially high [42].

Additionally, one interesting study has demonstrated that under conditions of elevated oxidative stress in mammals and also in plants, an overproduction of melatonin takes place [43]. In accordance with that study, our study showed that chronic oral melatonin administration significantly abrogates the higher circulating levels of TBARS, one of the reliable indicators of membrane LPO caused by ROS. Such data are inedited because the literature lacks data concerning to prevention of the oxidative stress in a chronic Chagas' disease model under melatonin therapy.

It is well established that robust pro-inflammatory cytokine responses during the acute phase of $T$. cruzi infection are necessary for the efficient development of protective cell-mediated and humoral immune responses. In contrast, the chronic pathological processes of Chagas' disease are thought to be related to excessive and/or prolonged pro-inflammatory responses with parasite-dependent myocardial damage, autonomic derangements, and microcirculatory disturbances [44]. Recent studies have reported that the IL-17 is essential to the control of inflammation during T. cruzi infection as it plays a negative feedback role in the production of IFN- $\gamma$ and chemokines, modulating the cardiac immune-mediated lesions found in patients with Chagas' disease [45]. Moreover, subsequent research [46] has demonstrated that low levels of the cytokines IL10 and IL-17 in association with high levels of IFN- $\gamma$ and TNF- $\alpha$ are directly correlated with the severity of $T$. cruzi infection.

Additionally, melatonin has been reported as a potential inducer of Th17 response [47]. In contrast, others authors indicate that melatonin treatment decreases the intracellular levels of IL-17A [48]. In the present study, melatonin treatment showed a rising trend in production of IL-17A cytokines in $T$. cruzi-infected and melatonin-treated animals.

The production of chemokines, a family of structurally related chemotactic cytokines that direct the migration or trafficking of leukocytes, appears to be induced and/or sustained in response to parasite antigens, during the later stages of $T$. cruzi infection. CCL2, also known as monocyte chemoattractant protein-1 (MCP-1), is the initially discovered and most extensively studied chemokine, being produced by a variety of cell types, either constitutively or after induction by oxidative stress, cytokines, or growth factors. The involvement of chemotactic cytokines in disease outcomes and in host immune-pathology during infection with $T$. cruzi has been discussed. Talvani et al. [49] demonstrated that patients with more severe Chagas' disease had elevated plasma concentrations of MCP-1/CCL2. In addition, the same authors also observed a correlation between MCP-1 levels and the degree of heart dysfunction in infected patients who developed different clinical forms of chronic chagasic cardiomyopathy.

Consistent with its multifunctional role in mediating diverse immunological functions, melatonin reverses chronic and acute inflammation, as several groups have 
shown [50, 51]. The ability of melatonin to influence the production and signaling of numerous inflammatory cytokines was previously demonstrated by our group [22].

In recent years, it has become apparent that melatonin prevents the translocation of $\mathrm{NF}-\kappa \mathrm{B}$ [52], a transcription factor that is activated in response to various inflammatory stimuli. A reduced upregulation of a variety of pro-inflammatory cytokines happens when lower NF- $\kappa \mathrm{B}$ transcription takes place. Furthermore, several studies have shown that melatonin improves the clinical course of illnesses that have an inflammatory etiology $[36,53]$.

The actions of this indolamine can be attributed not only to melatonin, but also to its metabolites, namely N1acetyl-N2-formyl-5-methoxykynuramine (AFMK) and N1-acetyl-5-methoxykynuramine (AMK), as demonstrated by Mayo and coworkers [54]. In a model of alcoholic liver injury, melatonin reduced neutrophilic infiltration and decreased MCP-1 levels in the serum [55]. In accordance with that, in our experiment, we observed a significant decrease in the percentages of both MCP-1-producing $\mathrm{CD}^{+}{ }^{+} \mathrm{T}$ and $\mathrm{CD} 8^{+} \mathrm{T}$ cells in the infected and melatonintreated animals.

LFA-1 (CD11a/CD18), which is constitutively expressed on the surface of leukocytes, is involved in lymphocyte recirculation and participates in the recruitment of cells to sites of inflammation [56, 57]. Leukocyte migration involves the interaction of CD11a/CD18 with the endothelial ligand ICAM-1 [58]. Integrins usually exist in a resting (inactive) nonadhesive state and are activated by high concentrations of divalent cations, chemokines, engagement of the TCR, and binding to their major endothelial counter-receptor CD54 (ICAM-1) [56, 59].

The importance of LFA-1 during T. cruzi infection results from the fact that chronic myocarditis is accompanied by an increased frequency of peripheral $\mathrm{CCR}^{+}{ }^{+}$LFA-1 ${ }^{+}$T lymphocytes [60]. Studies conducted by dos Santos et al. [61] also demonstrated a predominance of LFA- $1^{\mathrm{High}} \mathrm{CD} 8^{+} \mathrm{T}$ cells in the spleens of mice chronically infected with $T$. cruzi. Confirming this, our data showed that the levels of LFA-1 (CD11a) on CD4T cells from T. cruzi-infected rats displayed statistically increased values when compared to the control groups.

Recent studies indicate that melatonin reduces adhesion molecules and pro-inflammatory cytokines and modifies inflammatory factors in the serum [53]. In accordance with that, we showed that the percentages of $\mathrm{LFA}^{-} 1^{+} \mathrm{CD} 8 \mathrm{~T}$ lymphocytes were reduced in uninfected animals under melatonin therapy.

Macrophages and APC cells play critical roles in the interface between innate and adaptive immunity, being involved in many aspects of the immune response, including phagocytosis, antigen presentation, and secretion of bioactive molecules [62]. A study from our research group showed that the protective effect of melatonin during chronic Chagas' disease was associated with the immunomodulatory properties of this substance, promoting a reduction in the macrophage counts in treated adult Wistar rats (100 days) as compared to untreated counterparts [25]. In the present study, melatonin administration in chronic T. cruzi-infected Wistar rats also demonstrated pronounced protective properties, decreasing the percentages of spleen and peritoneal macrophages as well as APC cells. However, no difference was observed in the expression of MHC class II RT1B in the infected and melatonin-treated animals.

Based on the several studies that demonstrate the importance of melatonin and which have already been used to promote a proven multitude of therapeutic functionalities, our results demonstrated a potential protective role of this substance in downmodulating the excessive inflammation during the chronic Chagas' disease, partially mediated by the abrogation of LPO. Others studies have also demonstrated that during Schistosoma mansoni infection, melatonin actions can minimize the intensity of the oxidative damage [63].

The prevention of oxidative stress in a chronic Chagas' disease model, by antioxidant compounds such as melatonin, emerges as a new and promising approach for further investigation on treatment trials for infectious diseases.

\section{Acknowledgements}

We thank Inara Fernanda Lage Gallo and Cristiana Gonçalez for technical support and Fabiana Rossetto de Morais of College of Pharmaceutical Sciences of Ribeirão Preto (FCFRP), University of São Paulo for the FACS data analysis. This study was supported by fellowships from FAPESP.

\section{Author contributions}

We hereby certify that it is an original publication and the manuscript has not been previously submitted or published elsewhere. FS, MF, RC, GT, and MT conceived the study design and conducted the studies. VB, CT, and JP performed the statistical analyses, participated in the study design, and helped in drafting of the manuscript. All authors have made substantial contributions and final approval of the conceptions, drafting, and final version.

\section{References}

1. Dominguez-Rodriguez A, Abreu-Gonzalez P, Reiter RJ. Melatonin and cardiovascular disease: myth or reality? Rev Esp Cardiol (Engl Ed) 2012; 65:215-218.

2. Reiter RJ, Tan DX, Manchester LC et al. Medical implications of melatonin: receptor mediated and receptor independent actions. Adv Med Sci 2007; 52:11-28.

3. Hardeland R, Madrid JA, TAn DX et al. Melatonin, the circadian multioscillator system and health: the need for detailed analyses of peripheral melatonin signaling. J Pineal Res 2012; 52:139-166.

4. Hardeland R, Cardinali DP, Srinivasan V et al. Melatonin-a pleiotropic, orchestrating regulator molecule. Prog Neurobiol 2011; 93:350-384.

5. Reiter RJ, Calvo JR, Karbownik M et al. Melatonin and its relation to the immune system and inflammation. Ann N Y Acad Sci 2000; 917:376-386.

6. Rodriguez C, Mayo JC, SAinz RM et al. Regulation of antioxidant enzymes: a significant role for melatonin. J Pineal Res 2004; 36:1-9. 
7. Galano A, Tan DX, Reiter RJ. On the free radical scavenging actions of melatonin's metabolites, AMFK and AMK. J Pineal Res 2013; 54:255-257.

8. ZhANG HM, ZhANG Y. Melatonin, a well-documented antioxidant with conditional pro-oxidant actions. J Pineal Res 2014; 57:131-146.

9. Mauriz Jl, Callado PS, Veneroso $\mathrm{C}$ et al. A review of the molecular aspects of melatonin's anti-inflammatory actions: recent insights and new perspectives. J Pineal Res 2013; 54:1-14.

10. Reiter RJ, Tan DX, Osuna $\mathrm{C}$ et al. Actions of melatonin in the reduction of oxidative stress. A review. J Biomed Sci 2000; 7:444-458.

11. Bejarano I, Monllor F, Marchena AM et al. Exogenous melatonin supplementation prevents oxidative stress-evoked DNA damage in human spermatozoa. J Pineal Res 2014; 57:333-339.

12. Garcia JJ, López-Pingarrón L, Almeida-Souza P et al. Protective effects of melatonin in reducing oxidative stress and in preserving the fluidity of biological membranes: a review. J Pineal Res 2014; 56:225-237.

13. Reiter RJ, Tan DX, Galano A. Melatonin reduces lipid peroxidation and membrane viscosity. Front Physiol 2014; 5:377.

14. Bonnefont-Rousselot D, Collin F. Melatonin: action as antioxidant and potential applications in human disease and aging. Toxicology 2010; 278:55-67.

15. Reiter RJ, Tan DX, Rosales-Corral $S$ et al. The universal nature, unequal distribution and antioxidant functions of melatonin and its derivatives. Mini Rev Med Chem 2013; 13:373-384.

16. Cuzzocrea S, Constantino G, Caputia P. Protective effect of melatonin on cellular energy depletion mediated by peroxynitrite and poly (ADP-ribose) synthetase activation in a nonseptic shock model mediated by zymosan in the rat. J Pineal Res 1998; 25:78-85.

17. Schfield CJ, Jannin J, Salvatella R. The future of Chagas disease control. Trends Parasitol 2006; 22:583-588.

18. Kirchhoff LV, Paredes P, Lomelí-Guerrero A et al. Transfusion-associated Chagas disease (American trypanosomiasis) in Mexico: implications for transfusion medicine in the United States. Transfusion 2006; 46:298-304.

19. Santello FH, Frare EO, dos Santos CD et al. Melatonin treatment reduces the severity of experimental Trypanosoma cruzi infection. J Pineal Res 2007; 42:359-363.

20. Kuehn CC, Rodrigues OLG, Santos CD et al. Melatonin and dehydroepiandrosterone combination: does this treatment exert a synergistic effect during experimental Trypanosoma cruzi infection? J Pineal Res 2009; 47:253-259.

21. Oliveira LG, Kuehn CC, dos Santos CD et al. Protective actions of melatonin against heart damage during chronic Chagas disease. Acta Trop 2013; 128:652-658.

22. Brazão V, Santello FH, Filipin Mdel V et al. Immunoregulatory actions of melatonin and zinc during chronic Trypanosoma cruzi infection. J Pineal Res 2015; 58:210-218.

23. de Oliveira TB, Pedrosa RC, Filho DW. Oxidative stress in chronic cardiopathy associated with Chagas disease. Int J Cardiol 2007; 116:357-363.

24. Machado FS, Dutra WO, Esper L et al. Current understanding of immunity to Trypanosoma cruzi infection and pathogenesis of Chagas disease. Semin Immunopathol 2012; 34:753-770.

25. Brazão V, Del Vecchio Filipin M, Santello FH et al. Melatonin and zinc treatment: distinctive modulation of cytokine production in chronic experimental Trypanosoma cruzi infection. Cytokine 2011; 56:627-632.

26. Silva LHP, Nussenzweig V. Sobre uma cepa de Trypanosoma cruzi altamente virulenta para o camundongo branco. Folha Clín Biol 1953; 20:191-201.

27. BRener Z. The behavior of slender and stout forms of Trypanosoma cruzi in the blood-stream of normal and immune mice. Ann Trop Med Parasitol 1969; 63:215-220.

28. Brazão V, Santello FH, Caetano LC et al. Immunomodulatory effects of zinc and DHEA on the Th-1 immune response in rats infected with Trypanosoma cruzi. Immunobiology 2010; 215:427-434.

29. Gonzaga NA, Mecawi AS, Antunes-Rodrigues $J$ et al. Ethanol withdrawal increases oxidative stress and reduces nitric oxide bioavailability in the vasculature of rats. Alcohol 2015; 49:47-56.

30. Maçao LB, Wilhelm-Filho D, Pedrosa RC et al. Antioxidant therapy attenuates oxidative stress in chronic cardiopathy associated with Chagas' disease. Int J Cardiol 2007; 123:43-49.

31. Nagajyothi F, Desruisseaux MS, Machado FS et al. Response of adipose tissue to early infection with Trypanosoma cruzi (Brazil strain). J Infect Dis 2012a; 205:830-840.

32. Martinon F. Signaling by ROS drives inflammasome activation. Eur J Immunol 2010; 40:616-619.

33. Kim H, Hwang JS, Woo CH et al. TNF-alpha-induced upregulation of intercellular adhesion molecule- 1 is regulated by a Rac-ROS-dependent cascade in human airway epithelial cells. Exp Mol Med 2008; 40:167-175.

34. Cristofanon S, Morceau F, Scovassi Ai et al. Oxidative, multistep activation of the noncanonical NF-kappaB pathway via disulfide Bcl-3/p50 complex. FASEB J 2009; 23:45-57.

35. Ribeiro CM, Budni P, Pedrosa RC et al. Antioxidant therapy attenuates oxidative insult caused by benzonidazole in chronic Chagas' heart disease. Int J Cardiol 2010; 145:2733.

36. Pozo D, Reiter RJ, Calvo JR et al. Inhibition of cerebellar nitric oxide synthase and cyclic GMP production by melatonin via complex formation with calmodulin. J Cell Biochem 1997; 65:430-442.

37. Fridovich I. Fundamental aspects of reactive oxygen species, or what's the matter with oxygen? Ann N Y Acad Sci 1999; 893:13-18.

38. Yun-Zhong F, Sheng Y, Guoyao WU. Free radicals, antioxidants, and nutrition. Nutrition 2002; 18:872-879.

39. Noda Y, Mori A, Liburty R et al. Melatonin and its precursor scavenge nitric oxide. J Pineal Res 1999; 27:159-163.

40. Tamura EK, Cecon E, Monteiro AW et al. Melatonin inhibits LPS-induced NO production in rat endothelial cells. J Pineal Res 2009; 46:268-274.

41. Tan DX, Manchester LC, Liu X et al. Mitochondria and chloroplasts as the original sites of melatonin synthesis: a hypothesis related to melatonin's primary function and evolution in eukaryotes. J Pineal Res 2013; 54:127-138.

42. Cerraulo L, Ferrugia M, Tesoriere L et al. Interactions of melatonin with membrane models: portioning of melatonin in AOT and lecithin micelles. J Pineal Res 1999; 26:108-112.

43. Arnao MB, Hernández-Ruiz J. Growth conditions determine different melatonin levels in Lupinus albus L. J Pineal Res 2013; 55:149-155.

44. Marin-Neto JA, Cunha-Neto E, Maciel BC et al. Pathogenesis of chronic Chagas heart disease. Circulation 2007; 115:1109-1123. 
45. Gutierrez Fr, Guedes PM, Gazzinelli RT et al. The role of parasite persistence in pathogenesis of Chagas heart disease. Parasite Immunol 2009; 31:673-685.

46. Guedes PM, Gutierrez FR, Silva GK et al. Deficient regulatory $\mathrm{T}$ cell activity and low frequency of IL-17producing $\mathrm{T}$ cells correlate with the extent of cardiomyopathy in human Chagas' disease. PLoS Negl Trop Dis 2012; 6: e1630.

47. Kuklina EM. Melatonin as potential inducer of Th17 cell differentiation. Med Hypotheses 2014; 83:404-406.

48. Álvarez-Sánchez N, Cruz-Chamorro I, López-GonzÁlez A et al. Melatonin controls experimental autoimmune encephalomyelitis by altering the $\mathrm{T}$ effector/regulatory balance. Brain Behav Immun 2015. pii: S0889-159100230-5. doi: 10.1016/j.bbi.2015.06.021.

49. Talvani A, Rocha MO, Barcelos LS et al. Elevated concentrations of CCL2 and tumor necrosis factor-alpha in chagasic cardiomyopathy. Clin Infect Dis 2004; 38:943-950.

50. Cuzzocrea S, Zingarelli B, Gilad E et al. Protective effect of melatonin in carrageenan-induced models of local inflammation: relationship to its inhibitory effect on nitric oxide production and its peroxynitrite scavenging activity. J Pineal Res 1997; 23:106-116.

51. Costantino G, Cuzzocrea S, Mazzon E et al. Protective effects of melatonin in zymosan-activated plasma-induced paw inflammation. Eur J Pharmacol 1998; 363:57-63.

52. Mohan N, Sadeghi K, Reiter RJ et al. The neurohormone melatonin inhibits cytokine, mitogen and ionizing radiation induced NF-kappa B. Biochem Mol Biol Int 1996; 37:10631070 .

53. Esposito E, Cuzzocrea S. Antiinflammatory activity of melatonin in central nervous system. Curr Neuropharmacol 2010; 8:228-242.

54. Mayo JC, Sainz RM, TAN DX et al. Anti-inflammatory actions of melatonin and its metabolites, N1-acetyl-N2-formyl-5-methoxykynuramine (AFMK) and N1-acetyl-5-meth- oxykynuramine (AMK), in macrophages. J Neuroimmunol 2005; 165:139-149.

55. Kireev RA, Cuesta S, Ibarrola $\mathrm{C}$ et al. Age-related differences in hepatic ischemia/reperfusion Gene activation, liver injury, and protective effect of melatonin. J Surg Res 2012; 178:922-934.

56. Dustin ML, Springer TA. T-cell receptor cross-linking transiently stimulates adhesiveness through LFA-1. Nature 1989; 341:619-624.

57. Hogg N, Laschinger M, Giles K et al. T-cell integrins: more than just sticking points. J Cell Sci 2003; 116:4695-4705.

58. Dustin ML, Springer TA. Lymphocyte function-associated antigen-1 (LFA-1) interaction with intercellular adhesion molecule-1 (ICAM-1) is one of at least three mechanisms for lymphocyte adhesion to cultured endothelial cells. J Cell Biol 1988; 107:321-328.

59. Campbell JJ, Hedrick J, Zlotnik A et al. Chemokines and the arrest of lymphocytes rolling under flow conditions. Science 1998; 279:381-384.

60. Medeiros GA, Silvério JC, Marino AP et al. Treatment of chronically Trypanosoma cruzi-infected mice with a CCR1/ CCR5 antagonist (Met-RANTES) results in amelioration of cardiac tissue damage. Microbes Infect 2009; 11:264-273.

61. dos Santos PV, Roffê E, Santiago HC et al. Prevalence of $\mathrm{CD} 8^{(+)}$alpha beta $\mathrm{T}$ cells in Trypanosoma cruzi-elicited myocarditis is associated with acquisition of CD62L(Low) LFA-1(High)VLA-4(High) activation phenotype and expression of IFN-gamma-inducible adhesion and chemoattractant molecules. Microbes Infect 2001; 3:971-984.

62. Seljelid R, Eskeland T. The biology of macrophages: I. General principles and properties. Eur J Haematol 1993; 51:267-275.

63. El-Sokkary GH, Omar HM, Hassanein AF et al. Melatonin reduces oxidative damage and increases survival of mice infected with Schistosoma mansoni. Free Radic Biol Med 2002; 32:319-332. 


\title{
Ageing is not associated with an altered immune response during Trypanosoma cruzi infection Ageing and Trypanosoma cruzi infection
}

\author{
Rafaela Pravato Colato ${ }^{a}$, Vânia Brazão a, Fabricia Helena Santello a, Míriam Paula Alonso Toldo a , \\ Gabriel Tavares do Vale ${ }^{\mathrm{b}}$, Carlos Renato Tirapelli ${ }^{\mathrm{b}}$, Gabriela Pereira-da-Silva ${ }^{\mathrm{c}}$, José Clóvis do Prado Jr ${ }^{\mathrm{a}, *}$ \\ a College of Pharmaceutical Sciences of Ribeirão Preto (FCFRP), University of São Paulo, Ribeirão Preto, SP, Brazil \\ b Department of Psychiatric Nursing and Human Sciences, Laboratory of Pharmacology, College of Nursing of Ribeirão Preto, USP, Ribeirão Preto, SP, Brazil \\ c Department of Maternal-Infant Nursing and Public Health, College of Nursing of Ribeirão Preto, USP, Ribeirão Preto, SP, Brazil
}

\section{A R T I C L E I N F O}

\section{Article history:}

Received 12 May 2016

Received in revised form 19 January 2017

Accepted 23 January 2017

Available online 25 January 2017

Section Editor: Chennai Guest Editor

\section{Keywords:}

Ageing

Trypanosoma cruzi

Immune response

\begin{abstract}
A B S T R A C T
The aims of this work were to evaluate the influence of ageing on the magnitude of the immune response in male Wistar rats infected with the Y strain of Trypanosoma cruzi (T. cruzi). Infected young animals displayed enhanced $\mathrm{CD}^{+} \mathrm{T}$ cells as compared to uninfected counterparts. Ageing also triggered a significant reduction in $\mathrm{CD}^{+} \mathrm{T}$ cells compared to young and uninfected groups. The percentage of spleen NKT cells was reduced for all groups, regardless of the infection status. Significant decreased B-cells was noted in aged controls and infected animals as compared to young counterparts. A significant decrease in MHC class II (RT1B) expression in all aged animals was observed, whether infected or not. The highest and significant levels of Thiobarbituric Acid Reactive Substances (TBARS) were noted in the aged and infected animals as compared to young-infected ones (16 day). Consequently superoxide dismutase (SOD) activity was reduced for both control and infected aged animals. Significant elevation of 8-isoprostane levels was found in aged control and infected animals. Plasma glutathione (GSH) concentration was reduced in aged control animals, as well as, in the young infected animals. NO production was increased in both infected and uninfected aged animals compared to young infected and uninfected animals. Corticosterone levels were elevated in aged animals, whether infected or not. Thus, our results are inedited since the immune response is not worsened by the simple fact of animals being older. Ageing by itself triggered a damaged immune response as well as enhanced reactive oxygen species, when compared to young counterparts, but it did not contribute to impair the immune response of $T$. cruzi infected and aged rats.
\end{abstract}

(c) 2017 Elsevier Inc. All rights reserved.

\section{Introduction}

Over the last decade, the age of the developed world's population has increased by $>10 \%$ (Vincent and Velkoff, 2010), and updated data has revealed that the proportion of the aged population (65 years and older) will double from the current value of $7 \%$ of the total world population to $14 \%$ in 2040.

In humans as well in many animal species, ageing results in the accumulation of a wide range of physical, psychological and behavioral alterations. In the elderly, both innate and acquired immunity undergo are subject to ageing, which is followed by a chronic inflammatory state, considered by several authors to be responsible for inflammatory age-related diseases (Phillis and Kenneth, 2004). An impaired antigen

\footnotetext{
* Corresponding author at: Department of Clinical Analysis, Toxicology and Bromatology, School of Pharmaceutical Sciences of Ribeirão Preto, University of São Paulo, Av. do Café s/n, 14040-903 Ribeirão Preto, São Paulo, Brazil.

E-mail address: jcprado@fcfrp.usp.br (J.C. do Prado).
}

presenting capacity of the immune cells is reflected in a decreased ability to process antigens, as well as the reduced presence of costimulatory receptors such as $\mathrm{CD} 80 / \mathrm{CD} 86$, consequently affecting the levels of cytokines produced in their microenvironment (Miller et al., 1994; Donnini et al., 2002).

The hallmark of ageing is the extensive decrease in $\mathrm{T}$ cell function (Vasto et al., 2006), as well as in B cell activity. The most severe clinical impact seems to be triggered by the loss of diversity in the TCR and Bcell-receptor repertoire, resulting in the accumulation of dysfunctional cells, and decreased output of cells from bone-marrow and thymus (Fülöp et al., 2007). Furthermore, ageing also has deleterious effects on hematopoietic stem cells and on the lymphoid progenitors to mature lymphocytes in secondary lymphoid organs (Phillis and Kenneth, 2004).

Another prominent change associated with ageing is the increased generation of free radicals, including reactive oxygen species (ROS) and reactive nitrogen species (RNS). The resulting imbalance between the generation of ROS and the antioxidant defenses is known as 
oxidative stress (OS). Free radicals trigger detrimental cellular effects such as protein oxidation, lipid peroxidation, and DNA damage (Lobo et al., 2010). The tissue damage caused by free radical accumulation damage (Domenico et al., 2007) constitutes the basis of the free radical theory of ageing.

A key antioxidant role is played by superoxide dismutase (SOD), which is responsible for catalyzing the dismutation of superoxide anion $\left(\mathrm{O}_{2}^{-}\right)$to oxygen and hydrogen peroxide $\left(\mathrm{H}_{2} \mathrm{O}_{2}\right)$. Subsequently, glutathione peroxidase utilizes reduced glutathione ( $\mathrm{GSH}$ ) to convert $\mathrm{H}_{2} \mathrm{O}_{2}$ into water. Due to its scavenger properties, Because of its free sulfhydryl, GSH is also an important component of the non-enzymatic antioxidant system, functioning through transfer of a hydrogen atom to free radicals (Chaudieáre and Ferrari-Iliou, 1999; Li et al., 2013).

Chagas disease, which is caused by the intracellular protozoan parasite $T$. cruzi, affects approximately six to seven million people from southern California to South America and Western Europe (Bern et al., 2007; WHO, 2015). In endemic regions, infection is generally transmitted by blood-sucking triatomine insects and is considered to be the leading cause of premature heart disease (WHO, 2015). Around 28.000 new cases per year and 8.000 newborns infected during gestation, and $>100$ million people are at risk of infection. Even in nonendemic regions transmission can occur, however. Europe, for example, hosts large numbers of Latin American migrants, a considerable percentage of whom are chronically infected with $T$. cruzi. Although the absence of the triatomine vector prevents vector-borne transmission in Europe, Chagas' disease has nevertheless been spread through vertical transmission, blood transfusion and organ transplantation. In fact, >65 million people live in areas of exposure and are at risk of contracting the disease.

Given the risks of infection, and knowing that aged suffer more severe symptoms, there is a pressing need to evaluate acute $T$. cruzi infection in aged subjects. Wistar rats were chosen as experimental models and were infected with the Y strain of T. cruzi. The following immune parameters were evaluated by flow cytometry, including the expression of RT1B and the percentages of NK $\left(\mathrm{CD} 161^{+}\right)$, NKT $\left(\mathrm{CD} 3^{+} \mathrm{CD} 161^{+}\right)$, B cells, $\mathrm{CD} 4^{+} \mathrm{T}$ and $\mathrm{CD} 8^{+} \mathrm{T}$ cells. Systemic oxidative stress was evaluated by measuring the production of thiobarbituric acid reactive substances (TBARS), SOD activity, and the levels of 8-Isoprostane and GSH. The NO production and corticosterone concentrations were also determined.

\section{Methods}

\subsection{Animals}

All procedures involving animals were carried out in strict accordance with the current requirements of animal care guidelines and were approved by the local Ethics Committee (protocol number 2014.1.928.53.0). For the purpose of this study, 24 male Wistar rats (five weeks old), weighing 180-250 g, and 24 male wistar rats (eighteen months old), weighing 500-600 g were ordered from the Facility House of the University Campus of Ribeirão Preto. Animals were randomized into the following groups: young control (YC), young infected $(\mathrm{YI})$, aged control $(\mathrm{AC})$ and aged infected $(\mathrm{AI})$. The animals were kept on a 12-h light/12-h dark cycle with commercial rodent diet and water available ad libitum. Rat bedding was changed 3 times/week to avoid ammonia concentration from urine.

\subsection{Experimental infection, parasites and euthanasia}

Rats were intraperitoneally (i.p.) inoculated with $1 \times 10^{5}$ blood trypomastigotes of the Y strain of $T$. cruzi. Animals were firstly anesthetized with tribromoethanol $2.5 \%$, by means of an intraperitoneal dose of $0.1 \mathrm{ml} / 10 \mathrm{~g}$ of body weight. Soon after animal lost consciousness, they were decapitated. The assays were performed on 9 and 16 days after infection, according to the parasitemic peak.

\subsection{Preparation of tissues and cells}

Male Wistar rats were decapitated and the spleens were excised. To obtain cell suspensions, the spleen tissues were cut into small fragments and dispersed by extrusion through a $70 \mu \mathrm{m}$ Nylon Cell Strainer and macerated in RPMI 1640 medium to produce a single cell suspension from which the cells extruded spontaneously. The remaining tissue fragments were eliminated by sedimentation. To obtain peritoneal cells, an injection of $5 \mathrm{ml}$ of cold RPMI 1640 medium into the peritoneal cavity was done followed by a soft massage and peritoneal cells were harvested. The cells were centrifuged at $410 \mathrm{~g}$ for $15 \mathrm{~min}$, the pellet was resuspended in RPMI 1640 medium and diluted (1:10) with Trypan solution $(0.4 \%)$, and the cells were counted in a Neubauer chamber.

\subsection{Flow cytometry}

Cells from the peritoneal suspension and spleen organ were plated at a density of $2 \times 10^{6}$ cells/well in 96-well microplates. Following Fc receptor blocking, cells were incubated with color combinations of the monoclonal antibodies anti-CD3-allophycocyanin (APC) or fluoresceinisotiocianate (FITC), anti-CD4-phycoerythrin (PE) or PECy7, anti-CD8-peridinin-chlorophyll-protein complex (PerCP), antiCD45RA-PE, anti-CD161-FITC and anti-RT1B-PE (Activation marker). Stained cells were stored for analysis in PBS containing 1\% paraformaldehyde, in sealed tubes held in the dark. All steps were performed at $4{ }^{\circ} \mathrm{C}$. Analysis of these cells was performed using a Becton Dickinson FACScan flow cytometer with DIVA-BD software (Becton Dickinson Immunocytometry Systems, San Jose, CA, USA).

\subsection{Plasma measurement of TBARS}

The blood samples (volume of $10 \mathrm{ml}$ ) were collected into chilled plastic tubes containing EDTA, and centrifuged for $20 \mathrm{~min}$ at $2000 \mathrm{~g}$ at $4{ }^{\circ} \mathrm{C}$ for plasma separation and stored in Eppendorfs tubes at $-80{ }^{\circ} \mathrm{C}$ prior to dosage. The concentration of TBARS in plasma samples was determined colorimetrically (at $540 \mathrm{~nm}$ ) using a commercially available kit (\#10009055, Cayman Chemical, Ann Arbor, MI, USA). Results are expressed as $\mathrm{nmol} / \mathrm{ml}$ of plasma.

\subsection{Plasma measurement of SOD activity}

Superoxide dismutase (SOD) activity was analyzed in plasma following instructions of a commercially available kit (\#19160, SigmaAldrich, St. Louis, MO, USA). The results were expressed as inhibition rate $\% / \mathrm{ml}$ of plasma.

\subsection{Plasma measurement of 8-isoprostane}

8-Isoprostane dosages were made according to instructions of a commercially available kit (Cayman Chemical Company, Ann Arbor, Michigan, USA - 516351). Briefly, $50 \mu$ of plasma was added to ELISA plate to start the competition with 8 -isoprostane tracer (isoprostane 8 -acetylcholinesterase conjugate) by specific antibodies binding, followed by a secondary antibody binding (Anti-Rabbit IgG). After coupling, Ellman's reagent containing acetylcholine was added which reacts with the 8-isoprostane tracer bound to the antibody. The reaction product has a yellow color. After measuring absorbance of standards and samples $(450 \mathrm{~nm})$ plasma 8-isoprostane was determined and values expressed in $\mathrm{pg} / \mathrm{ml}$ plasma.

\subsection{Plasma measurement of GSH concentration}

Glutathione (GSH) content in plasma was analyzed through the oxidation of GSH by DTNB [5,5'-dithio-bis-(2-nitrobenzoic acid)] to form the product 5'-thio-2-nitrobenzoic (TNB-yellow product) as described previously (Simplicio et al., 2016). The samples were analyzed 
spectrophotometrically (Cirrus $80 \mathrm{ST}$, Femto, Brazil) at $415 \mathrm{~nm}$, and results are expressed as $\mu \mathrm{g} \mathrm{GSH} / \mathrm{ml}$ of plasma.

\subsection{NO production}

Production of NO was determined by measuring total nitrite/nitrate $\left(\mathrm{NO}_{2}^{-} / \mathrm{NO}_{3}^{-}\right)$by the Griess reaction. Total $\mathrm{NO}_{2}^{-} / \mathrm{NO}_{3}^{-}$levels were determined with the $\mathrm{NO}_{3}^{-}$in the serum samples $(0.08 \mathrm{ml})$ converted to $\mathrm{NO}_{2}^{-}$by incubation of $0.01 \mathrm{ml}$ nitrate reductase from Aspergillus species and $0.01 \mathrm{ml} \mathrm{NADPH}(1 \mathrm{~mm})$ for $30 \mathrm{~min}$ at $37^{\circ} \mathrm{C} . \mathrm{NO}_{2}^{-}$levels were determined spectrophotometrically at $540 \mathrm{~nm}$ by measuring the absorbance of test samples $(0.1 \mathrm{ml})$ after adding $0.1 \mathrm{ml}$ Griess reagent (sulphanilic acid and $\mathrm{N}$-(1-naphthyl)ethylenediamine) in $5 \%$ phosphoric acid) and comparing these values with those from standard solutions of $\mathrm{NaNO}_{2}$ (1-100 $\mu \mathrm{m})$ (Rocha et al., 2002).

\subsection{Corticosterone concentrations}

The blood samples were collected in chilled tubes containing EDTA K2 for corticosterone determination. Plasma was separated by centrifugation (3700 rpm) and immediately stored at $-80{ }^{\circ} \mathrm{C}$ until analysis via radioimmunoassay (RIA). All samples were analyzed in duplicate.

\section{Statistical analysis}

The results are expressed as means \pm standard error of mean (SEM). A value of $\mathrm{p}<0.05$ was considered statistically significant. The methods used for statistical analysis were chosen considering the small sample size. Differences among groups were determined by one-way ANOVA with Bonferroni's post test. All statistical analyses were performed using Graph Pad Prism version 5.0 (GraphPad Software, Inc., San Diego, CA, USA).

\section{Results}

\section{1. $C D 4^{+}$and $C D 8^{+}$T cells}

On experimental day 9 , the numbers of $\mathrm{CD}^{+} \mathrm{T}$ cells were significantly reduced in both the aged control and infected rats as compared to their young counterparts. Moreover, during the acute phase of infection, the young and infected animals displayed elevated percentages of $\mathrm{CD}^{+}{ }^{+} \mathrm{T}$ subsets when compared to young non-infected counterparts (Fig. 1).

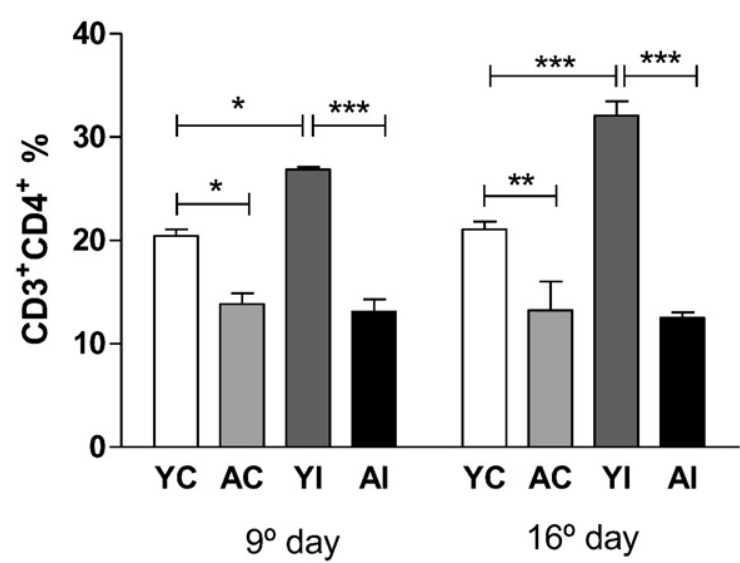

Fig. 1. Ageing down regulates $\mathrm{CD} 4^{+} \mathrm{T}$ cells expression in male Wistar rats, on the 9 and 16th day post-infection of experimental T. cruzi infection, for the following groups: young control (YC), aged control (AC), young infected (YI) and aged infected (AI). Oneway ANOVA with Bonferroni's multiple comparison test were used to compare groups $\left({ }^{*} \mathrm{p}<0,05,{ }^{* *} \mathrm{p}<0,01\right.$ and $\left.{ }^{* * *} \mathrm{p}<0,001\right)$. All data are expressed as mean \pm SEM. $n=5$ / group/day of experiment.
In the control groups, ageing triggered a significant reduction in the numbers of $\mathrm{CD}^{+} \mathrm{T}$ cells when compared to the young and uninfected groups (Fig. 2). It was also observed that the percentage of $\mathrm{CD}^{+} \mathrm{T}$ cells was significantly reduced in aged and infected animals as compared to young and infected animals (Fig. 2).

\subsection{B cells}

There was a profound decrease in the percentages of $B$ cells (CD45RA) in aged controls as compared to young animals. The same behavior was observed in aged infected animals, with a significant decline in the B cell compartment for aged and infected animals as compared to their young counterparts (Fig. 3).

\section{3. $C D 28^{+}$expression analysis in $C D 4^{+}$and $C D 8^{+} T$ lymphocytes subpopulations}

Reduced $\mathrm{CD}_{28}{ }^{+}$expression is associated with ageing and involves the costimulatory signals required for $\mathrm{T}$ cell activation and proliferation. In our experiments, the characteristic loss of the CD28 surface marker was confirmed, since the percentage of $\mathrm{CD} 4{ }^{+} \mathrm{CD} 28^{+}$positive $\mathrm{T}$ cells and $\mathrm{CD}^{+}{ }^{+} \mathrm{CD} 28^{+}$positive was changed. The significant decline in $\mathrm{CD}_{2} 8^{+}$molecule expression was observed in aged infected or not infected animals, when compared to young counterparts ( 9 and 16 day) (see Fig. 4).

\subsection{Innate immune response}

In order to determine the real influence of ageing and the innate immune response during T. cruzi infection, the percentages of NK and NKT cells were analyzed.

As shown in Fig. 5 it can be seen that the percentages of NK cells were unaffected by ageing in aged control animals when compared to young and control animals. Another important fact to be emphasized is that the present study showed that ageing affected the percentage of spleen NKT cells for any group, regardless of the infection status (Fig. 6), since reduced percentages of these cells were found in aged animals as compared to young animals.

In addition, the present authors aimed to determine if processing by MHC class II (RT1B expression) presented changes with ageing. An interesting observation was that the percentage of peritoneal macrophages expressing RT1B was found to be down-regulated during ageing. Our data reveal a statistically significant decrease in RT1B

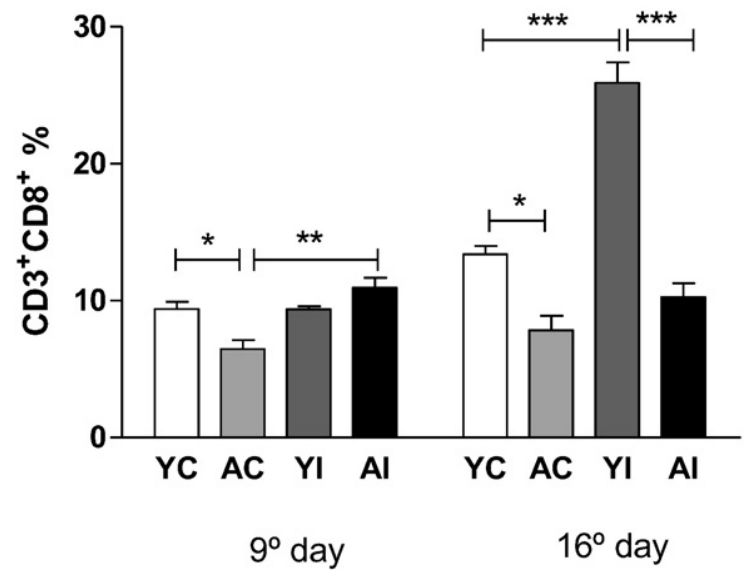

Fig. 2. Ageing down regulates $\mathrm{CD}^{+} \mathrm{T}$ cells expression in male Wistar rats, on the 9 and 16th day post-infection of experimental T. cruzi infection, for the following groups: young control (YC), aged control (AC), young infected (YI) and aged infected (AI). Oneway ANOVA with Bonferroni's multiple comparison test were used to compare groups $\left({ }^{*} \mathrm{p}<0,05,{ }^{* *} \mathrm{p}<0,01\right.$ and $\left.{ }^{* * *} \mathrm{p}<0,001\right)$. All data are expressed as mean \pm SEM. $n=5 /$ group/day of experiment. 


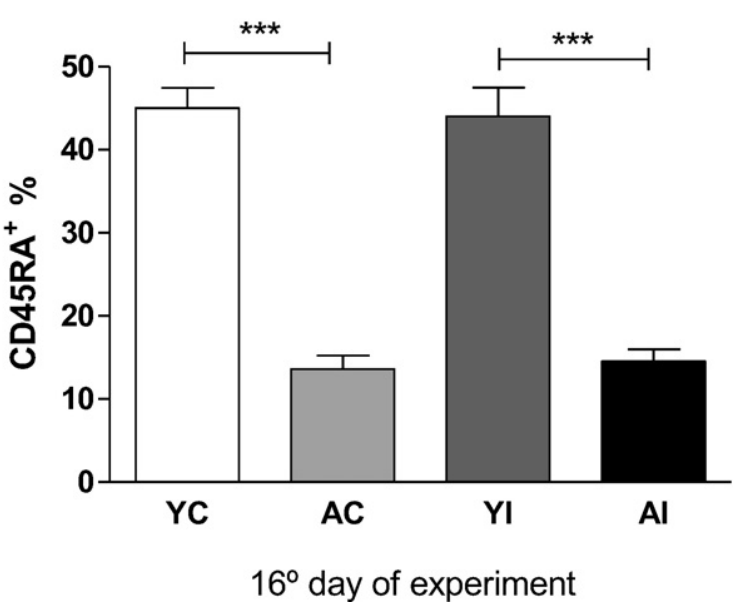

Fig. 3. Ageing down regulates B lymphocytes expression in male Wistar rats, on the 16th day post-infection of experimental T. cruzi infection, for the following groups: young control (YC), aged control (AC), young infected (YI) and aged infected (AI). One-way ANOVA with Bonferroni's multiple comparison test were used to compare groups $\left({ }^{* * *} \mathrm{p}<0,001\right)$. All data are expressed as mean \pm SEM. $n=5 /$ group/day of experiment.

expression in infected and aged animals, as compared to their young and infected counterparts. Furthermore, infected young and aged animals had a significant increased proportion of RT1B when compared to uninfected young and aged counterparts, confirming that an increased expression of surface markers such as MHC II occurred during T. cruzi infection in both infected groups (Fig. 7).

\subsection{Plasma measurement of TBARS}

The other objective of this study was to determine if ageing was associated with changes in the initiation and/or progression of lipid peroxidation. On experimental day 16, aged animals showed a nonstatistically significant trend for increased concentrations of TBARS in the plasma, as compared to their young and uninfected counterparts.

During acute $T$. cruzi infection, 16 days post infection, the highest and significant TBARS $(\mathrm{p}<0.001)$ levels were noted in the aged infected animals as compared to young infected ones (Fig. 8).

\subsection{Plasma measurement of SOD activity}

To determine if ageing was associated with changes in the enzymatic activity SOD, the inhibition percentages per $\mathrm{ml}$ of plasma were analyzed. On experimental day 9 and 16, aged animals showed a significant

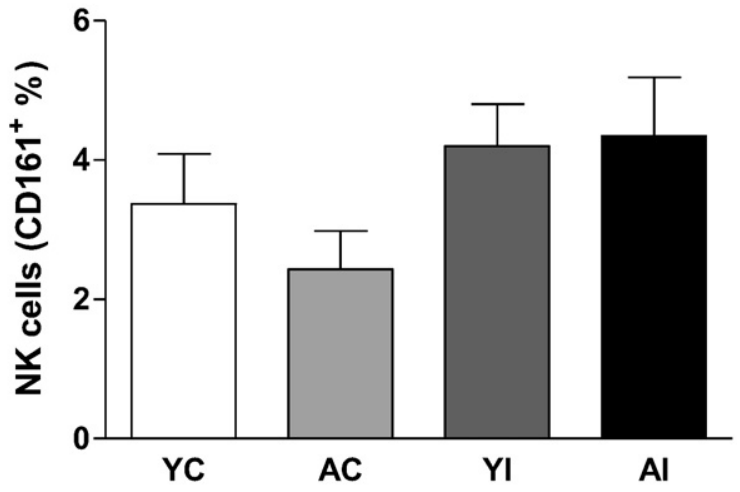

$9^{\circ}$ day of experiment

Fig. 5. Phenotypic characterization of splenic NK cells obtained from male Wistar rats i.p. infected with $1.0 \times 10^{5}$ blood trypomastigotes of the Y strain of $T$. cruzi on the 9 th day postinfection of experimental disease, for the following groups: young control (YC), aged control (AC), young infected (YI) and aged infected (AI). One-way ANOVA with Bonferroni's multiple comparison test were used to compare groups. All data are expressed as mean \pm SEM. $n=5$ /group/day of experiment.

reduction in the SOD activity when compared to the young infected and uninfected groups (16 day) (see Fig. 9).

\subsection{Plasma measurement of 8-isoprostane}

On experimental day 9, the concentration of 8-isoprostane was significantly higher in the young and aged infected animals as compared to young uninfected groups. Moreover, on experimental day 16, the young and infected animals displayed enhanced 8-isoprostane level as compared to young and aged uninfected groups, as well as in aged infected animals (Fig. 10).

\subsection{Plasma measurement of GSH concentration}

Control aged animals displayed increased levels of GSH as compared to young ones. Moreover, GSH concentration was significantly increased in the young and infected animals when compared to young counterparts ( 9 and 16 day) (see Fig. 11).

\subsection{NO production}

It has been demonstrated that $\mathrm{NO}$ can react with $\mathrm{O}_{2}^{-}$to produce ONOO, a recognized initiator of lipid peroxidation, so for this reason, it
(A)

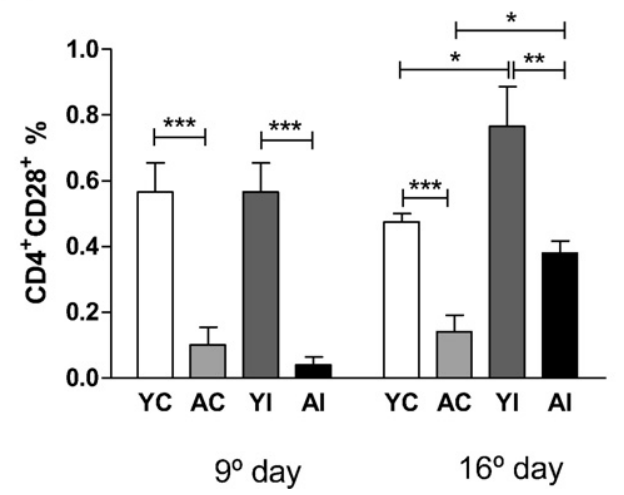

(B)

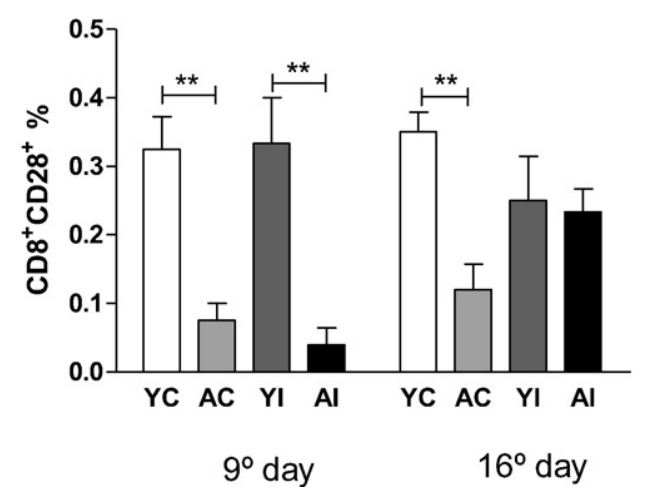

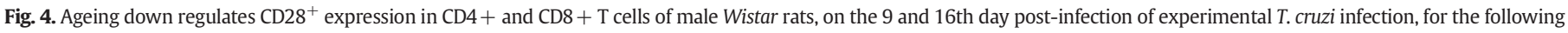

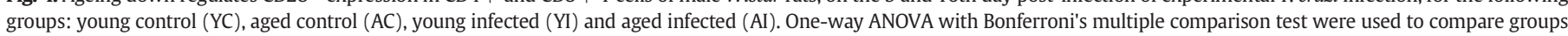
$\left({ }^{*} \mathrm{p}<0,05,{ }^{* *} \mathrm{p}<0,01\right.$ and $\left.{ }^{* * *} \mathrm{p}<0,001\right)$. All data are expressed as mean \pm SEM. $n=5$ /group/day of experiment. 


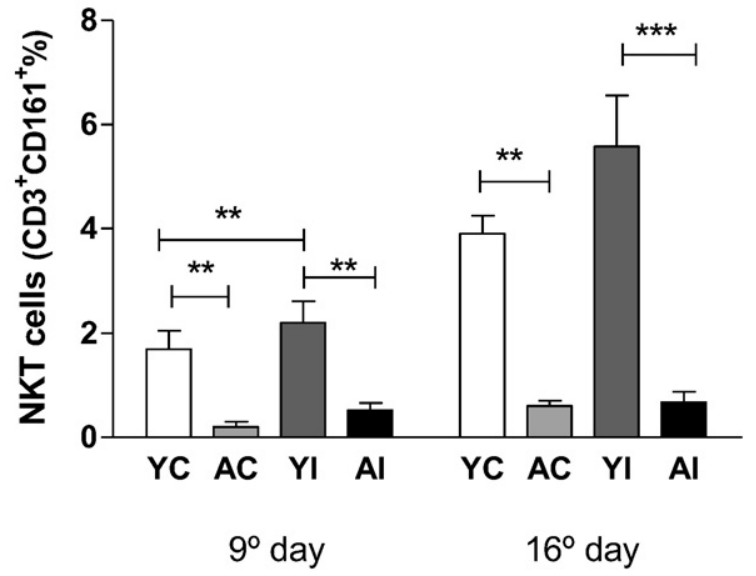

Fig. 6. Phenotypic characterization of splenic NKT cells obtained from male Wistar rats i.p. infected with $1.0 \times 10^{5}$ blood trypomastigotes of the Y strain of $T$. cruzi on the 9th and 16th day post-infection of experimental disease, for the following groups: young control (YC), aged control $(\mathrm{AC})$, young infected $(\mathrm{YI})$ and aged infected $(\mathrm{AI})$. One-way ANOVA with Bonferroni's multiple comparison test were used to compare groups ( ${ }^{* *} \mathrm{p}<0,01$ and $\left.{ }^{* * *} \mathrm{p}<0,001\right)$. All data are expressed as mean \pm SEM. $n=5 /$ group/day of experiment.

was examined whether ageing affected NO production during T. cruzi infections. On experimental day 9, the nitrite concentration reached the highest significant values for infected animals as compared to their uninfected counterparts $(\mathrm{p}<0.05)$ (Fig. 12).

On experimental day 16 , the aged control animals showed an increase in NO production as compared to young animals. A significant increase in NO levels was also found in the aged and infected animals as compared to the young ones (Fig. 12).

\subsection{Corticosterone}

Corticosterone, the major circulating glucocorticoid in rats, increased throughout ageing. Aged animals displayed the highest levels of this hormone as compared to their young counterparts, whether infected or otherwise.

The corticosterone levels also increased during acute T. cruzi infections, as observed in young infected animals, as compared to their uninfected counterparts (Fig. 13).

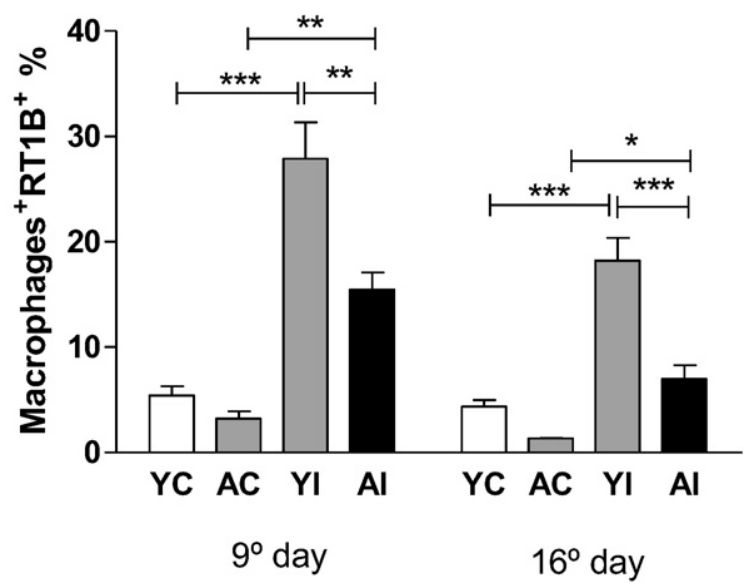

Fig. 7. Expression of activation-related cell surface molecules (RT1B) in peritoneal macrophages from male Wistar rats, on the 9th and 16th day post-infection of experimental T. cruzi infection, for the following groups: young control (YC), aged control (AC), young infected (YI) and aged infected (AI). One-way ANOVA with Bonferroni's multiple comparison test were used to compare groups ( ${ }^{*} \mathrm{p}<0,05$, ${ }^{* *} \mathrm{p}<0,01$ and $\left.{ }^{* * *} \mathrm{p}<0,001\right)$. All data are expressed as mean \pm SEM. $n=5 /$ group/day of experiment.

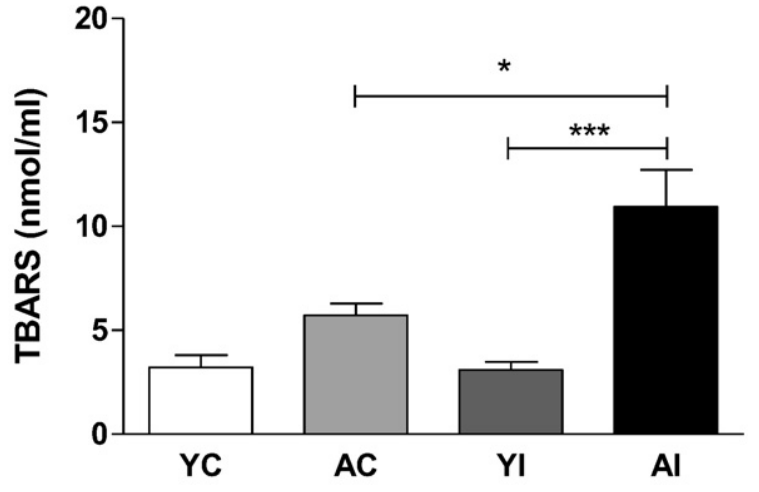

$16^{\circ}$ day of experiment

Fig. 8. Plasma concentration of TBARS, a marker of oxidative stress, from male Wistar rats infected with $1.0 \times 10^{5}$ blood trypomastigotes of the Y strain of $T$. cruzi on the 16 th day post-infection of experimental disease, for the following groups: young control (YC), aged control $(\mathrm{AC})$, young infected $(\mathrm{YI})$ and aged infected $(\mathrm{AI})$. One-way ANOVA with Bonferroni's multiple comparison test were used to compare groups ( ${ }^{*} \mathrm{p}<0,05$ and $\left.{ }^{* * *} \mathrm{p}<0,001\right)$. All data are expressed as mean \pm SEM. $n=5$ /group/day of experiment.

\section{Discussion}

Ageing is a complex process involving a set of physiological changes, which negatively affect the immune system with defects range from the hematopoietic bone marrow to weakness in peripheral lymphocyte migration, maturation and function. The consequences of the ageing process are characterized by an accelerated immune senescent phenotype, enhanced susceptibility to infections, autoimmunity and impaired responsiveness of the immune system (Goronzy and Weyand, 2003, 2012). With data supporting the notion that in T. cruzi infected subjects ineffective immune responses might worsen the clinical signals of this disease, the authors address the question of whether the agedependent decrease in immunological competence, characteristic of the older rats, would influence the immune response to $T$. cruzi infection.

During the ageing process, the $\mathrm{T}$ cell compartment seems to be most dramatically affected. Changes in the bone marrow and thymus microenvironment as well as increased deregulation of compensatory

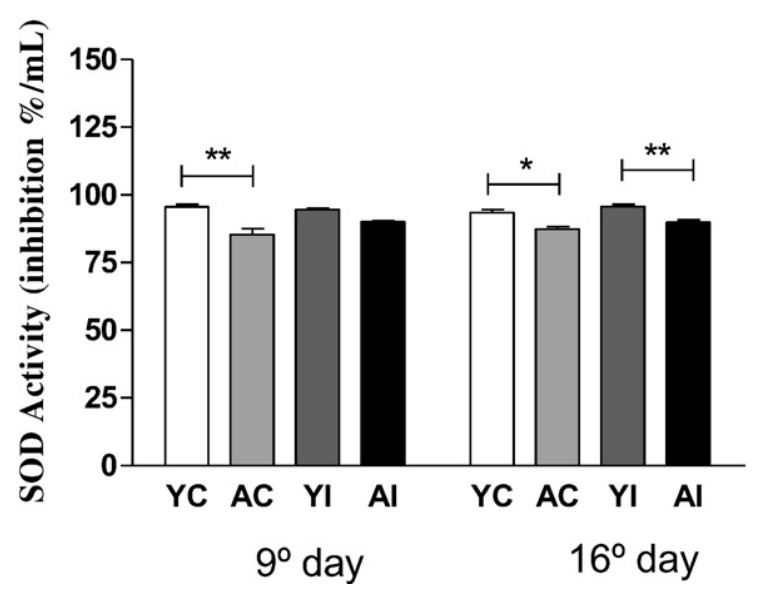

Fig. 9. Plasma SOD activity, from male Wistar rats infected with $1.0 \times 10^{5}$ blood trypomastigotes of the Y strain of $T$. cruzi on the 9 th and 16th day post-infection of experimental disease, for the following groups: young control (YC), aged control (AC), young infected (YI) and aged infected (AI). One-way ANOVA with Bonferroni's multiple comparison test were used to compare groups ( ${ }^{*} \mathrm{p}<0,05$ and ${ }^{* *} \mathrm{p}<0,01$ ). All data are expressed as mean \pm SEM. $n=5$ /group/day of experiment. 


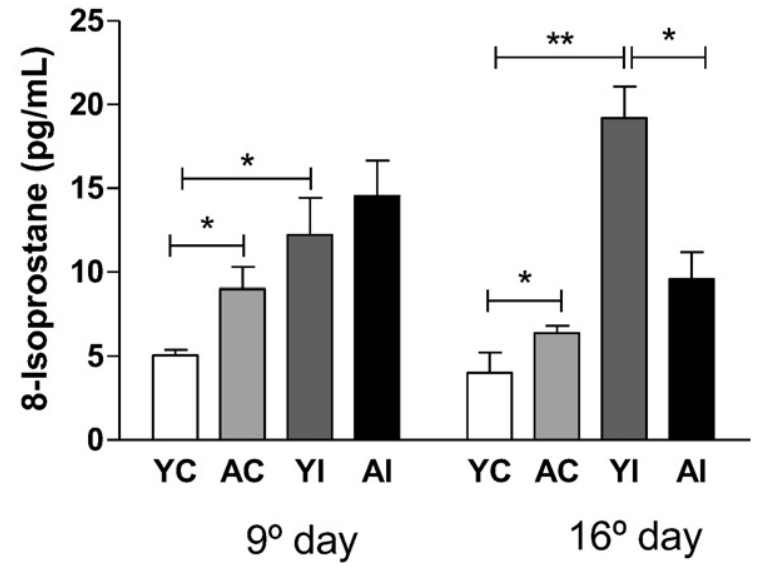

Fig. 10. Plasma concentration of 8-Isoprostane, a marker of oxidative stress, from male Wistar rats infected with $1.0 \times 10^{5}$ blood trypomastigotes of the Y strain of $T$. cruzi on the 16th day post-infection of experimental disease, for the following groups: young control (YC), aged control (AC), young infected (YI) and aged infected (AI). One-way ANOVA with Bonferroni's multiple comparison test were used to compare groups $\left({ }^{*} \mathrm{p}<0,05\right.$ and $\left.{ }^{* *} \mathrm{p}<0,01\right)$. All data are expressed as mean \pm SEM. $n=5 /$ group/day of experiment.

homeostatic mechanisms trigger a quantitative and qualitative loss of naïve T lymphocytes (Messaoudi et al., 2006a, 2006b, Dutilh and de Boer, 2003, Kilpatrick et al., 2008; Naylor et al., 2005). As a consequence, aged hosts have increased difficulty in mounting an effective $\mathrm{T}$ cell immune response to clear the pathogens away, whereas memory maintenance and recall responses appear to be less modified (Brien et al., 2009; Kapasi et al., 2002). Our data confirm the previous statements, where a significant reduction in aged control and infected host's $\mathrm{CD}^{+}$and $\mathrm{CD}^{+} \mathrm{T}$ lymphocytes as compared to their young control and infected counterparts, thus concluding that the ageing process did not impair the $\mathrm{T}$ cell immune response of infected subjects.

Controversial studies regarding to ageing alterations of the innate immune cells have been observed, with some reporting little or no change, whereas others reporting a significant decline in functional immune response. The functional deficiencies of aged NK cells comprise multiple factors: a decreased production of NK cells in the bone marrow, a loss in their functional ability (Dussault and Miller, 1994), an

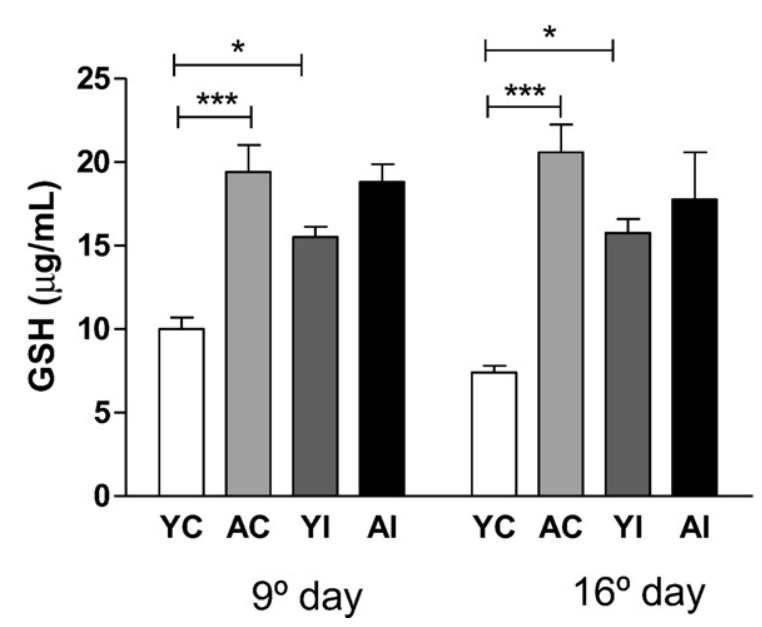

Fig. 11. Plasma concentration of GSH, from male Wistar rats infected with $1.0 \times 10^{5}$ blood trypomastigotes of the $Y$ strain of $T$. cruzi on the 16th day post-infection of experimental disease, for the following groups: young control (YC), aged control (AC), young infected (YI) and aged infected (AI). One-way ANOVA with Bonferroni's multiple comparison test were used to compare groups ( ${ }^{*} p<0,05$ and ${ }^{* * *} p<0,001$ ). All data are expressed as mean \pm SEM. $n=5 /$ group/day of experiment.

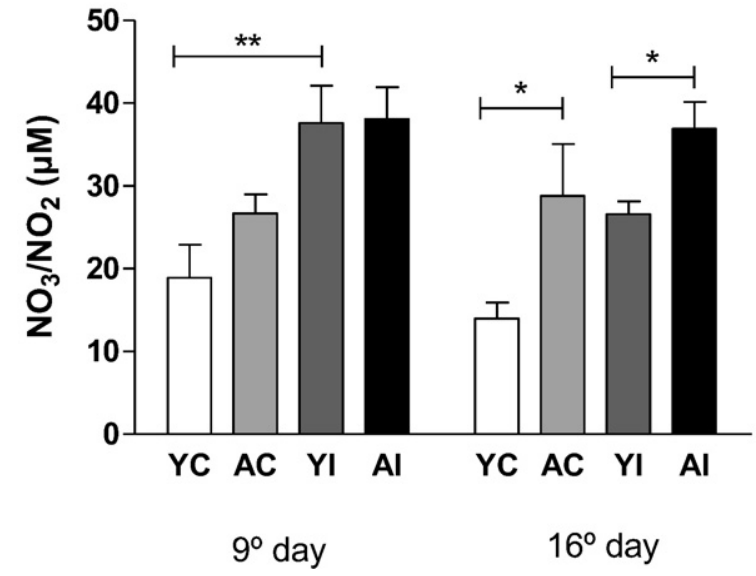

Fig. 12. Nitrite serum concentrations $(\mu \mathrm{M})$ in male Wistar rats infected with $1.0 \times 10^{5}$ blood trypomastigotes of the Y strain of $T$. cruzi on the 9 and 16th day post-infection of experimental disease, for the following groups: young control (YC), aged control (AC), young infected (YI) and aged infected (AI). One-way ANOVA with Bonferroni's multiple comparison test was used to compare groups $\left({ }^{*} \mathrm{p}<0,05\right.$ and $\left.{ }^{* *} \mathrm{p}<0,001\right)$. All data are expressed as mean \pm SEM. $n=5$ /group/day of experiment.

impairment in signal transduction (Mariani et al., 1998; Borrego et al., 1999) and a decrease in the production of lytic enzymes and other cytolytic proteins (Mariani et al., 1996, Dussault and Miller, 1994).

Additionally, a decreased in the blood NKT cells of elderly subjects have been also found (DelaRosa et al., 2002). These cells have been shown to be present in the thymus, liver, spleen and bone morrow, displaying cytotoxic abilities as well as providing signals required for driving the adaptive immune response (Dussault and Miller, 1994). Our results showed that the percentages of NK cells were unaffected by ageing in aged control animals when compared to young and control animals. However, reduced percentages of NKT cells were found in aged animals as compared to young counterparts.

With advancing age, for both mice and humans, a reduction in macrophage surface receptor expression, such as MHC (major histocompatibility complex) class II, has also been observed (Herrero et al., 2001; Solana et al., 2006). Defects in macrophage function (Agius et al., 2009) were observed in a study, which evaluated delayed-type hypersensitivity (DTH) responses to Candida antigens in aged humans. In line with this, the present study showed for aged animals, infected or

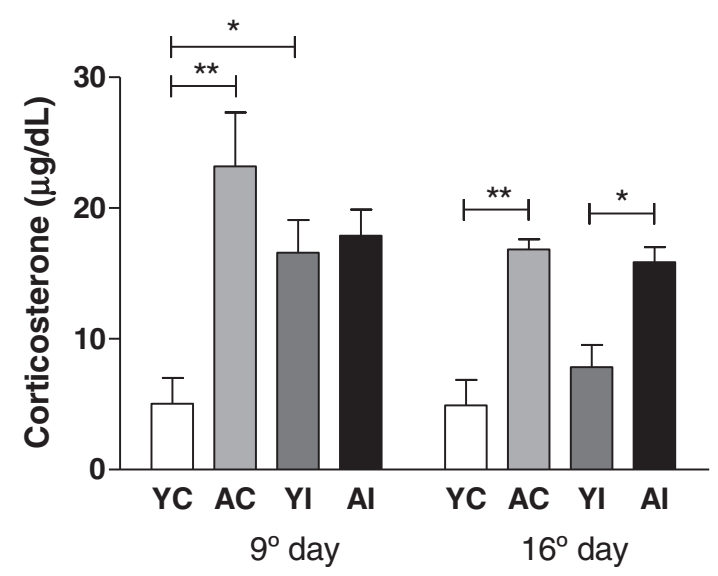

Fig. 13. Plasma corticosterone concentrations $(\mu \mathrm{g} / \mathrm{dl})$ of male Wistar rats, on the 9th and 16th day post-infection of experimental T. cruzi infection, for the following groups: young control $(\mathrm{YC})$, aged control $(\mathrm{AC})$, young infected $(\mathrm{YI})$ and aged infected $(\mathrm{AI})$. Oneway ANOVA with Bonferroni's multiple comparison test were used to compare groups $\left({ }^{*} \mathrm{p}<0,05\right.$ and $\left.{ }^{* *} \mathrm{p}<0,01\right)$. All data are expressed as mean \pm SEM. $n=5 /$ group/day of experiment. 
otherwise, a statistically reduced percentage of the MHC class II (RT1B) expression as compared to their young counterparts.

Age-associated immunological alterations in the humoral compartment of the immune system have also been demonstrated. The inhibition of B lymphopoiesis in elderly subjects has been described at multiple developmental stages, from the hematopoietic stem cells through to the late stages of new B cell generation not only affecting its homeostasis but also its functions (Linton and Dorshkind, 2004; Cancro et al., 2009; Scholz et al., 2013).

It has been well established that humoral immunity is a crucial step to control T. cruzi invasion and the depletion of B cells results in increased parasitemia (Kumar and Tarleton, 2001). Our data clearly show that for aged control and infected Wistar rats a significant decrease in the percentage of CD45RA was observed as compared to control and infected young animals.

One of the most striking features of the co-stimulatory receptor CD28 is its close relationship with T cell activation, proliferation, and survival (Riley and June, 2005). At birth, virtually all T cells express CD28, and as long as individuals age, a decrease about 10 to $15 \%$ for $\mathrm{CD}^{+}{ }^{+} \mathrm{T}$ cells and 50 to $60 \%$ for CD8 $+\mathrm{T}$ cells occur (Fagnoni et al., 1996). Our results corroborate these previous conclusions, since our data confirmed the characteristic loss of the CD28 surface marker where the percentage of $\mathrm{CD} 4^{+} \mathrm{CD} 28^{+}$positive $\mathrm{T}$ cells and $\mathrm{CD}^{+} \mathrm{CD}_{28}{ }^{+}$positive were reduced. The significant decline in $\mathrm{CD} 28^{+}$ molecule expression was observed in aged infected or not infected animals, compared for young counterparts ( 9 and 16 day)

Physiological functions are impaired throughout the course of glucocorticoids and elevated corticosterone levels might contribute to the ageing process (Zambrano et al., 2015). In addition, it has been well established that stress responses could also substantially accelerate certain aspects of ageing (Selye, 1970). During stress, be it environmental, physiological or infectious, the hypothalamic-pituitary-adrenal axis (HPA) is stimulated consequently increasing the concentration of plasma cortisol.

Several papers have supported the idea that glucocorticoids have powerful immunosuppressive actions affecting among others the trafficking of $\mathrm{T}$ and $\mathrm{B}$ cells and impairing the effectors functions of phagocytes. Since the stress response is involved in the etiology of multiple chronic diseases, there are few studies relating ageing and plasma corticosterone levels during $T$. cruzi infection.

Corrêa-de-Santana et al. (2006) described the presence of T. cruzi antigens in the pituitary and adrenal glands during the acute phase of infection. These antigens trigger an imbalance in the HPA axis, decreasing the concentrations of corticotrophin-releasing hormone and increased levels of corticosterone, although no significant alterations in the serum ACTH levels were observed (Corrêa-de-Santana et al., 2006)

It has been well established that the fine, homeostatic interactions between the neuroendocrine-immune systems are regulated by $\mathrm{CRH}$, ACTH and glucocorticoids which modulates pro-inflammatory cytokine secretion and regulates peripheral immune functions in vivo (Webster et al., 1997). One example of this interaction is well described by Corrêa-de-Santana et al., 2006, Roggero et al., 2006 where the fate of a T. cruzi infection appears to be influenced by the basal levels of glucocorticoids, the kinetics of corticosterone (CT) release and the gonadal axis manipulations.

Regarding corticosterone levels, our data corroborate the previous statements since statistically increased levels of corticosterone were observed in young $T$. cruzi infected rats when compared to their uninfected counterparts. Once again our results confirm the influence of the glucocorticoid levels in the ageing process, where increased corticosterone levels were observed in all aged animals, as compared to young ones, whether infected or not.

Researchers have demonstrated that biological ageing is the progressive manifestation of accumulated cellular damage being determined by environmental or genetic factors (Harman, 1981; Ljubuncic and Reznick, 2009; Jin, 2010). ROS can activate the intracellular inflammatory signaling pathways promoting the migration of inflammatory cells across the endothelial barrier, leading to the release of inflammatory mediators into various tissues (Martinon, 2010), including cytokines produced by the activation of redox-regulated transcription factors such as factor nuclear kappa B (NF-кB) (Kim et al., 2008; Cristofanon et al., 2009).

ROS are involved in age-associated damage to macromolecules, proteins, lipids and nucleic acids, leading, for example, to lipid peroxidation and DNA mutations (Mamelak, 2007; Valko et al., 2007) triggering a derangement in ROS-mediated cell signaling, resulting in stress and disease (Bouzid et al., 2015). Other investigators have also demonstrated that aged cells can activate hyper-production of ROS (Chen et al., 1995). One of the most important biomarkers of oxidative-stress is 8-iso prostaglandin $F_{2 \alpha}$ (8-isoprostane), which is formed by a non-enzymatic reaction, leading to oxidation of arachidonic acid from phospholipid membranes (Morrow and Roberts, 1996). During Chagas' disease increased activity of phospholipase $A_{2}$ stimulates enhanced synthesis of arachidonic acid (Sharma et al., 2013, 2014). Increased ROS production takes place during T. cruzi infection (Machado-Silva et al., 2016) and can react with excessive arachidonic acid leading to formation of 8isoprostane. In our experiments high levels of 8-isoprostane were found in aged animals as compared to young counterparts, but no significant differences were found between infected and uninfected aged rats.

Kawamoto et al. (2013) showed that the content of TBARS, another biomarker of lipid peroxidation, seems to influence NO synthase (NOS) activity consequently enhancing NO concentrations. Our experiments demonstrated enhanced TBARS levels for infected and aged animals as compared to their control aged rats as well as control and infected young counterparts. Consequently, increased concentrations of NO levels were observed in control and infected aged rats as compared to control and infected young ones, but no significant differences were found between aged infected and uninfected subjects.

Some researchers have reported that lipid peroxidation is closely associated with cellular ageing. In accordance with this ageing characteristic, the present research proposed the evaluation of a more accurate antioxidant data. At first, SOD plasma activity was analyzed. All three isoforms of SOD have the function of dismutase $\mathrm{O}_{2}^{-}$in oxygen and hydrogen peroxide, acting as a key antioxidant factor (Li et al., 2013). Our results demonstrated an age-related reduction of SOD activity in aged infected and uninfected subjects as compared to young ones, corroborating previous findings (De la Fuente et al., 2004a, 2004b; Fujimoto et al., 2010; Espino et al., 2010; Mladenov et al., 2015).

Glutathione peroxidase is another enzymatic antioxidant responsible for reducing hydrogen peroxide to water and lipid hydroperoxides, using GSH as a substrate. The present work demonstrated that young and infected rats displayed increased concentrations of GSH as compared to uninfected counterparts. For aged animals infection did not trigger statistical differences between infected and uninfected ones, although statistically increased levels of GSH were observed when comparing aged infected or not with young control counterparts, agreeing with recent data from Mladenov et al., 2015.

Our experiments confirm the reduced antioxidant activity, since increased concentrations of 8-isoprostane, nitrite and TBARS levels were found in senile animals as compared to their younger counterparts.

Before our experiments, almost nothing was known about the role of oxidative stress in the response to $T$. cruzi infection of ageing animals. Our results demonstrate that the immune response in aged and infected animals was not worsened by the fact of animals being older. Ageing by itself compromised the immune response, and elevated reactive oxygen species, when compared to young counterparts, but it did not contribute to impairment of the immune response of $T$. cruzi infected and aged rats.

\section{Statement of authorship}

We hereby certify that it is an original publication and the manuscript has not been previously submitted or published elsewhere. FS, 
RC, GT and MT conceived the study design and conducted the studies. VB, CT, GB and JP performed the statistical analyses, participated in the study design, and helped in drafting of the manuscript. All authors have made substantial contributions and final approval of the conceptions, drafting, and final version.

\section{Acknowledgments}

We thank Cristiana Gonçalez and Inara Fernanda Lage Gallo for technical support and Ms. Fabiana Rossetto de Morais of College of Pharmaceutical Sciences of Ribeirão Preto (FCFRP), University of São Paulo for the FACS data analysis. This study was supported by fellowships from FAPESP (2014/00303-6).

\section{References}

Agius, E., Lacy, K.E., Vukmanovic-Stejic, M., Jagger, A.L., Papageorgiou, A.P., Hall, S., Reed, J.R., Curnow, S.J., Fuentes-Duculan, J., Buckley, C.D., Salmon, M., Taams, L.S., Krueger, L.S., Greenwood, J., Klein, N., Rustin, M.H., Akbar, A.N., 2009. Decreased TNF-alpha synthesis by macrophages restricts cutaneous immunosurveillance by memory CD4 + T cells during aging. J. Exp. Med. 206, 1929-1940.

Bern, C., Montgomery, S.P., Herwaldt, B.L., Rassi Jr., A., Marin-Neto, J.A., Dantas, R.O. Maguire, J.H., Acquatella, H., Morillo, C., Kirchhoff, L.V., Gilman, R.H., Reyes, P.A., Salvatella, R., Moore, A.C., 2007. Evaluation and treatment of Chagas disease in the United States: a systematic review. JAMA 298, 2171-2181.

Borrego, F., Alonso, M.C., Galiani, M.D., Carracedo, J., Ramirez, R., Ostos, B., Peña, J., Solana, R., 1999. NK phenotypic markers and IL-2 response in NK cells from elderly people. Exp. Gerontol. 34, 253-265

Bouzid, M.A., Filaire, E., McCall, A., Fabre, C., 2015. Radical oxygen species, exercise and aging: an update. Sports Med. 45, 1245-1261.

Brien, J.D., Uhrlaub, J.L., Hirsch, A., Wiley, C.A., Nikolich-Zugich, J., 2009. Key role of T cell defects in age-related vulnerability to West Nile virus. J. Exp. Med. 206, 2735-2745.

Cancro, M., Hao, Y., Scholz, J., Riley, R., Frasca, D., Dunn-Walters, D., Blomberg, B.B., 2009. B cells and aging: molecules and mechanisms. Trends Immunol. 30, 313-318.

Chaudieáre, J., Ferrari-Iliou, R., 1999. Intracellular antioxidants: from chemical to biochemical mechanisms. Food Chem. Toxicol. 37, 949-962.

Chen, Q., Fischer, A., Reagan, J.D., Yan, L.J., Ames, B.N., 1995. Oxidative DNA damage and senescence of human diploid fibroblast cells. Proc. Natl. Acad. Sci. U. S. A. 92, 4337-4341.

Corrêa-de-Santana, E., Paez-Pereda, M., Theodoropoulou, M., Gruebler, Y., Nihei, O.K., Bozza, M., Arzt, E., Villa-Verde, D.M.S., Renner, U., Stalla, J., Stalla, G.K., Savino, W., 2006. Hypothalamus-pituitary-adrenal axis during Trypanosoma cruzi acute infection in mice. J. Neuroimmunol. 173, 12-22.

Cristofanon, S., Morceau, F., Scovassi, A.I., Dicato, M., Ghibelli, L., Diederich, M., 2009. Oxidative, multistep activation of the noncanonical NF-kappaB pathway via disulfide Bcl-3/p50 complex. FASEB J. 23, 45-57.

De la Fuente, M., Baeza, I., Guayerbas, N., Puerto, M., Castillo, C., Salazar, V., Ariznavarreta, C., F-tresguerres, J.A., 2004a. Changes with aging in several leukocyte functions of male and female rats. Biogerontology 5, 389-400

De la Fuente, M., Hernanz, A., Guayerbas, N., Alvarez, P., Alvarado, C., 2004b. Changes with age in peritoneal macrophage functions. Implication of leukocytes in the oxidative stress of senescence. Cell. Mol. Biol. 50, 683-690.

Delarosa, O., Tarazona, R., Casado, J.G., Alonso, C., Ostos, B., Peña, J., Solana, R., 2002. Valpha24 + NKT cells are decreased in elderly humans. Exp. Gerontol. 37, 213-217.

Domenico, F., Giuseppe, C., Maria, R.L.M., Matteo, C., 2007. Effects of antioxidant supplementation on the aging process. Clin. Interv. Aging 2, 377-387.

Donnini, A., Argentati, K., Mancini, R., Argentati, K., Provinciali, M., 2002. Phenotypeantigen presenting capacity and migration of antigen-presenting cells in young and old age. Exp. Gerontol. 37, 1097-1112.

Dussault, I., Miller, S.C., 1994. Decline in natural killer cell-mediated immunosurveillance in aging mice - a consequence of reduced cell production and tumor binding capacity. Mech. Aging Dev. 75, 115-129.

Dutilh, B.E., de Boer, R.J., 2003. Decline in excision circles requires homeostatic renewal or homeostatic death of naive T cells. J. Theor. Biol. 224, 351-358.

Espino, J., Bejarano, I., Paredes, S.D., González, D., Barriga, C., Reiter, R.J., Pariente, J.A., Rodríguez, A.B., 2010. Melatonin counteracts alterations in oxidative metabolism and cell viability induced by intracellular calcium overload in human leucocytes: changes with age. Basic Clin. Pharmacol. Toxicol. 107, 590-597.

Fagnoni, F.F., Vescovini, R., Mazzola, M., Bologna, G., Nigro, E., Lavagetto, G., Franceschi, C., Passeri, M., Sansoni, P., 1996. 1996. Expansion of cytotoxic CD8 + CD28 - T cells in healthy aging people, including centenarians. Immunology 88, 501-507.

Fujimoto, H., Kobayashi, H., Ohno, M., 2010. Age-induced reduction in mitochondrial manganese superoxide dismutase activity and tolerance of macrophages against apoptosis induced by oxidized low density lipoprotein. Circ. J. 74, 353-360.

Fülöp, T., Larbi, A., Hirokawa, K., Mocchegiani, E., Lesourds, B., Castle, S., Wikby, A Franceschi, C., Pawelec, G., 2007. Immunosupportive therapies in aging. Clin. Interv. Aging 2, 33-54.

Goronzy, J.J., Weyand, C.M., 2003. Aging, autoimmunity and arthritis: T-cell senescence and contraction of T-cell repertoire diversity - catalysts of autoimmunity and chronic inflammation. Arthritis Res. Ther. 5, 225-234.
Goronzy, J.J., Weyand, C.M., 2012. Immune aging and autoimmunity. Cell. Mol. Life Sci. 69, 1615-1623.

Harman, D., 1981. The aging process. Proc. Natl. Acad. Sci. U. S. A. 78, 7124-7128.

Herrero, C., Marques, L., Lloberas, J., Celada, A., 2001. IFN-gamma-dependent transcription of MHC class II IA is impaired in macrophages from aged mice. J. Clin. Invest. 107, 485-493.

Jin, K., 2010. Modern biological theories of aging. Aging Dis. 1, 72-74.

Kapasi, Z.F., Murali-Krishna, K., McRae, M.L., Ahmed, R., 2002. Defective generation but normal maintenance of memory T cells in old mice. Eur. J. Immunol. 32 1567-1573.

Kawamoto, E.M., Vasconcelos, A.R., Degaspari, S., Böhmer, A.E., Scavone, C., Marcourakis, T., 2013. Age-related changes in nitric oxide activity, cyclic GMP, and TBARS levels in platelets and erythrocytes reflect the oxidative status in central nervous system. Age (Dordr.) 35, 331-342.

Kilpatrick, R.D., Rickabaugh, T., Hultin, L.E., Hultin, P., Hausner, M.A., Detels, R., Phair, J., Jamieson, B.D., 2008. Homeostasis of the naive CD4 + T cell compartment during aging. J. Immunol. 180, 1499-1507.

Kim, H., Hwang, J.S., Woo, C.H., Kim, E.Y., Kim, T.H., Cho, K.J., Kim, J.H., Seo, J.M., Lee, S.S., 2008. TNF-alpha-induced up-regulation of intercellular adhesion molecule-1 is regulated by a Rac-ROS-dependent cascade in human airway epithelial cells. Exp. Mol Med. 40, 167-175 34.

Kumar, S., Tarleton, R.L., 2001. The relative contribution of antibody production and CD8 ${ }^{+}$ the cell function to immune control of Trypanosoma cruzi. Parasite Immunol. 166, 4596-4603.

Li, H., Horke, S., Forstermann, U., 2013. Oxidative stress in vascular disease and its pharmacological prevention. Trends Pharmacol. Sci. 34, 313-319.

Linton, P.J., Dorshkind, K., 2004. Age-related changes in lymphocyte development and function. Nat. Immunol. 5, 133-139.

Ljubuncic, P., Reznick, A.Z., 2009. The evolutionary theories of aging revisited - a minireview. Gerontology 55, 205-216.

Lobo, V., Patil, A., Phatak, A., Chandra, N., 2010. Free radicals, antioxidants and functiona foods: impact on human health. Pharmacogn. Rev. 4, 118-126.

Machado-Silva, A., Cerqueira, P.G., Grazielle-Silva, V., Gadelha, F.R., Peloso, E.F. Teixeira, S.M., Machado, C.R., 2016. How Trypanosoma cruzi deals with oxidative stress: antioxidant defence and DNA repair pathways. Mutat. Res. Rev. Mutat. Res. 767, 8-22.

Mamelak, M., 2007. Alzheimer's disease, oxidative stress and gammahydroxybutyrate. Neurobiol. Aging 28, 1340-1360.

Mariani, E., Sgobbi, S., Meneghetti, A., Tadolini, M., Tarozzi, A., Sinoppi, M., Cattini, L. Facchini, A., 1996. Perforins in human cytolytic cells: the effect of age. Mech. Aging Dev. 92, 195-209.

Mariani, E., Mariani, A.R., Meneghetti, A., Tarozzi, A., Cocco, L., Facchini, A., 1998. Agedependent decreases of NK cell phosphoinositide turnover during spontaneous but not Fc-mediated cytolytic activity. Int. Immunol. 10, 981-989.

Martinon, F., 2010. Signaling by ROS drives inflammasome activation. Eur. J. Immunol. 40 616-619.

Messaoudi, I., Warner, J., Nikolich-Zugich, J., 2006a. Age-related CD8 + T cell clonal expansions express elevated levels of CD122 and CD127 and display defects in perceiving homeostatic signals. J. Immunol. 177, 2784-2792.

Messaoudi, I., Warner, J., Nikolich-Zugich, D., Fischer, M., Nikolich-Zugich, J., 2006b. Molecular, cellular, and antigen requirements for development of age-associated $\mathrm{T}$ cell clonal expansions in vivo. J. Immunol. 176, 301-308.

Miller, C., Kelsoe, G., Han, S., 1994. Lack of B7-2 expression in germinal centers of aged mice. Aging Immunol. Infect. Dis. 5, 249-256.

Mladenov, M., Gokik, M., Hadzi-Petrushev, N., Gjorgoski, I., Jankulovski, N., 2015. The relationship between antioxidant enzymes and lipid peroxidation in senescent rat erythrocytes. Physiol. Res. 64, 891-896.

Morrow, J.D., Roberts II, L.J., 1996. The isoprostanes: current knowledge and directions for future research. Biochem. Pharmacol. 51, 1-9.

Naylor, K., Li, G., Vallejo, A.N., Lee, W.W., Koetz, K., Bryl, E., Witkowski, J., Fulbright, J., Weyand, C.M., Goronzy, J.J., 2005. The influence of age on T cell generation and TCR diversity. J. Immunol. 174, 7446-7452.

Phillis, J.L., Kenneth, D., 2004. Age-related changes in lymphocyte development and function. Nat. Immunol. 5, 133-139.

Riley, J.L., June, C.H., 2005. The CD28 family: a T cell rheostat for therapeutic control of T cell activation. Blood 105, 13-21.

Rocha, J.C.S., Peixoto, M.E.B., Jancar, S., Cunha, F.Q., Ribeiro, R.A., Rocha, F.A.C., 2002. Dual effect of nitric oxide in articular inflammatory pain in zymosan-induced arthritis in rats. Br. J. Pharmacol. 136, 588-596.

Roggero, E., Pérez, A.R., Tamae-Kakazu, M., Piazzon, I., Nepomnaschy, I., Besedovsky, H.O., Bottasso, O.A., del Rey, A., 2006. Endogenous glucocorticoids cause thymus atrophy but are protective during acute Trypanosoma cruzi infection. J. Endocrinol. 190, 495-503.

Scholz, J.L., Diaz, A., Riley, R.L., Cancro, M.P., Frasca, D., 2013. A comparative review of aging and B cell function in mice and humans. Curr. Opin. Immunol. 25, 504-510.

Selye, H., 1970. Stress and aging. J. Am. Geriatr. Soc. 18, 669-680.

Sharma, J., Eickhoff, C.S., Hoft, D.F., Ford, D.A., Gross, R.W., McHowat, J., 2013. The absence of my myocardial calcium-independent phospholipase A2y results in impaired prostaglandin E2 production and decreased survival in mice with acute Trypanosoma cruzi infection. Infect. Immun. 81, 2278-2287.

Sharma, J., Eickhoff, C.S., Hoft, D.F., Marentette, J.O., Turk, J., McHowat, J., 2014. Absence of calcium-independent phospholipase $A_{2} \beta$ impairs platelet-activating factor production and inflammatory cell recruitment in Trypanosoma cruzi-infected endothelial cells. Physiol. Rep. 2, e00196.

Simplicio, J.A., do Vale, G.T., Gonzaga, N.A., Leite, L.N., Hipólito, U.V., Pereira, C.A., Tostes, R.C., Tirapelli, C.R., 2016. Reactive oxygen species derived from NAD(P)H oxidase 
play a role on ethanol-induced hypertension and endothelial dysfunction in rat resistance arteries. J. Physiol. Biochem. http://dx.doi.org/10.1007/s13105-016-0519-z.

Solana, R., Pawelec, G., Tarazona, R., 2006. Aging and innate immunity. Immunity 24, 491-494.

Valko, M., Leibfritz, D., Moncol, J., Cronin, M.T.D., Mazur, M., Telser, J., 2007. Free radicals and antioxidants in normal physiological functions and human disease. Int. J. Biochem. Cell Biol. 39, 44-84.

Vasto, S., Malavolta, M., Pawelec, G., 2006. Age and immunity. Immun. Aging 3, 1-6.

Vincent, G.K., Velkoff, V.A., 2010. The Next Four Decades the Older Population in the United States: 2010-2050. Population Estimates and Projections. UDoCCB, Washington, DC, USA
Webster, C.D., Douglas, K.S., Eaves, D., Hart, S.D., 1997. Impulsivity: Theory, Assessment, and Treatment. Guildford, New York, pp. 252-277.

WHO - World Health Organization 2015. Chagas disease (American trypanosomiasis). Available from: who.int/mediacentre/factsheets/fs340/en/.

Zambrano, E., Reyes-Castro, L.A., Nathanielsz, P.W., 2015. Aging, glucocorticoids and developmental programming. Age (Dordr.) 37, 9774 


\title{
Effects of melatonin on thymic and oxidative stress dysfunctions during Trypanosoma cruzi infection
}

\author{
Vânia Brazão $^{1}$ (D) | Rafaela Pravato Colato ${ }^{1}$ | Fabricia Helena Santello $^{1}$ | \\ Gabriel Tavares do Vale $^{2}$ | Natália de Almeida Gonzaga ${ }^{2}$ | Carlos Renato Tirapelli ${ }^{2}$ | \\ José Clóvis do Prado Jr ${ }^{1}$
}

${ }^{1}$ College of Pharmaceutical Sciences of Ribeirão Preto (FCFRP), University of São Paulo, Ribeirão Preto, SP, Brazil

${ }^{2}$ Department of Psychiatric Nursing and Human Sciences, Laboratory of Pharmacology, College of Nursing of Ribeirão Preto, USP, Ribeirão Preto, SP, Brazil

\section{Correspondence}

Vânia Brazão, Departamento de Análises Clínicas, Toxicológicas e Bromatológicas, Faculdade de Ciências Farmacêuticas de Ribeirão Preto FCFRP-USP, Universidade de São Paulo, Ribeirão Preto, SP, Brazil. Email: vaniabrazao@gmail.com

Funding information

Fundação de Amparo à Pesquisa do Estado de São Paulo, Grant/Award Number: 2015/09806-3

\begin{abstract}
Although the exact etiology of Chagas disease is not completely elucidated, thymic atrophy and oxidative stress are believed to be important contributors to the pathogenesis during acute Trypanosoma cruzi (T. cruzi) infection. We hypothesized that exogenous melatonin, administered by gavage $(5 \mathrm{mg} / \mathrm{kg}$, p.o., gavage) to young (5 weeks old) and middle-aged (18 months old) male Wistar rats, would modulate thymic oxidative damage and reverse the age-related thymus regression during T. cruzi acute infection. Increased levels of superoxide anion $\left(\mathrm{O}_{2}{ }^{-}\right)$were detected in the thymus of infected animals, and treatment with melatonin reverted this response. We found reduced TBARS levels as well as a significant increase in superoxide dismutase (SOD) activity in the thymus of all middle-aged melatonin-treated animals, infected or not with T. cruzi. Furthermore, melatonin increased the thymic expression of SOD1 and SOD2 in middle-aged control animals. Nox2 expression was not affected by melatonin treatment in young or middle-aged animals. Melatonin reverted the age-related thymic regression as revealed by the increase in thymus weight, total number of thymocytes, and reduction in age-related accumulation of double-negative thymocytes. This is the first report to directly examine the effects of melatonin treatment on the thymic antioxidant/oxidant status and thymic changes during $T$. cruzi infection. Our results revealed new antioxidant features that turn melatonin a potentially useful compound for the treatment of Chagas disease, a condition in which an excessive oxidative damage occurs.
\end{abstract}

\section{K E Y W O R D S}

melatonin, oxidative stress, thymus, Trypanosoma cruzi

\section{1 | INTRODUCTION}

Chagas disease, also known as American trypanosomiasis, is a neglected tropical disease caused by the infection with the flagellate protozoan parasite Trypanosoma cruzi. This disease remains a serious health problem in Latin America, affecting nearly 8 million people, ${ }^{1}$ being endemic in 21 countries of the Americas, and it is an emerging threat to other nonendemic countries, mainly in the United States, Europe, and the Western Pacific Region, as a result of migration of infected persons and nonvectorial transmission routes, including as blood transfusion, organ transplantation, and congenital infection.

It is now well established that oxidative stress generated during acute T. cruzi infection as well as the inefficient scavenging of reactive oxygen species (ROS) seems to contribute 


\section{CYTO-18-188 - Interim Decision}

Cytokine <eesserver@eesmail.elsevier.com>

16 de abril de 2018 11:44

Responder a: Cytokine <cytokine@elsevier.com>

Para:vaniabrazao@gmail.com, vbrazao@eerp.usp.br

Cc: mmiller@mcmaster.ca

Ms. No.: CYTO-18-188

Title: Cytokine modulation, oxidative stress and thymic dysfunctions: role of age-related changes in the experimental Trypanosoma cruzi infection.

Corresponding Author: Dr. Vânia Brazão

Authors: Rafaela P Colato; Gabriel T do Vale; Fabricia H Santello; Pedro A Sampaio; Carlos R Tirapelli; Gabriela Pereira-da-Silva; José C Do Prado Jr

Dear Dr. Brazão,

Your manuscript, referenced above, has been reviewed and we invite you to revise the manuscript along the lines suggested for further consideration in Cytokine. Please carefully address the issues raised in the comments that are appended at the bottom of this message.

Please submit your revision online by 2018-07-15 00:00:00 logging onto the Elsevier Editorial System for Cytokine:

https://ees.elsevier.com/ycyto/

Your username is: vaniabrazao@gmail.com

If you need to retrieve password details, please go to:

http://ees.elsevier.com/ycyto/automail_query.asp.

NOTE: Upon submitting your revised manuscript, please upload the source files for your article. For additional details regarding acceptable file formats, please refer to the Guide for Authors at: http://www.elsevier.com/

journals/cytokine/1043-4666/guide-for-authors

When submitting your revised paper, we ask that you include the following items:

Manuscript and Figure Source Files (mandatory)

We cannot accommodate PDF manuscript files for production purposes. We also ask that when submitting your revision you follow the journal formatting guidelines. Figures and tables may be embedded within the source file for the submission as long as they are of sufficient resolution for Production. For any figure that cannot be embedded within the source file (such as *.PSD Photoshop files), the original figure needs to be uploaded separately. Refer to the Guide for Authors for additional information.

http://www.elsevier.com/journals/cytokine/1043-4666/guide-for-authors

Highlights (mandatory)

Highlights consist of a short collection of bullet points that convey the core findings of the article and should be submitted in a separate file in the online submission system. Please use 'Highlights' in the file name and include 3 to 5 bullet points (maximum 85 characters, including spaces, per bullet point). See the following website for more information

http://www.elsevier.com/highlights

Graphical Abstract (optional)

Graphical Abstracts should summarize the contents of the article in a concise, pictorial form designed to capture the attention of a wide readership online. Refer to the following website for more information: http://www.elsevier.com/ graphicalabstracts

The manuscript record can be found in the "Submissions Needing Revision" menu.

When submitting your revised paper, please include a separate document uploaded as "Response to Reviews" that carefully addresses the issues raised in the below comments, point by point. You should also include a suitable rebuttal to any specific request for change that has not been made.

To facilitate the electronic publication of your manuscript (should it be accepted), we request that your manuscript 


\section{Your manuscript EXG_2018_3_R1 has been sent for review}

Experimental Gerontology <EviseSupport@elsevier.com>

20 de abril de 2018 11:11

Responder a: exg@elsevier.com

Para: vaniabrazao@gmail.com

This message was sent automatically. Please do not reply.

Reference: EXG_2018_3_R1

Title: Melatonin treatment reverses and protects against immune and endocrine dysfunctions in middle-aged T. cruzi infected Wistar rats

Journal: Experimental Gerontology

Dear Dr. Brazão,

I am currently identifying and contacting reviewers who are acknowledged experts in the field. Since peer review is a voluntary service it can take time to find reviewers who are both qualified and available. While reviewers are being contacted, the status of your manuscript will appear in EVISE $\circledast$ as 'Reviewer Invited'.

Once a reviewer agrees to review your manuscript, the status will change to 'Under Review'. When I have received the required number of expert reviews, the status will change to 'Ready for Decision' while I evaluate the reviews before making a decision on your manuscript.

To track the status of your manuscript, please log into EVISE $\circledast$ and go to 'My Submissions' via:

http://www.evise.com/evise/faces/pages/navigation/NavController.jspx?JRNL_ACR=EXG

Kind regards,

Experimental Gerontology

Have questions or need assistance?

For further assistance, please visit our Customer Support site. Here you can search for solutions on a range of topics, find answers to frequently asked questions, and learn more about EVISE® via interactive tutorials. You can also talk $24 / 5$ to our customer support team by phone and $24 / 7$ by live chat and email.

Copyright @ 2018 Elsevier B.V. | Privacy Policy

Elsevier B.V., Radarweg 29, 1043 NX Amsterdam, The Netherlands, Reg. No. 33156677. 